“In Calli Ixcahuicopa” 


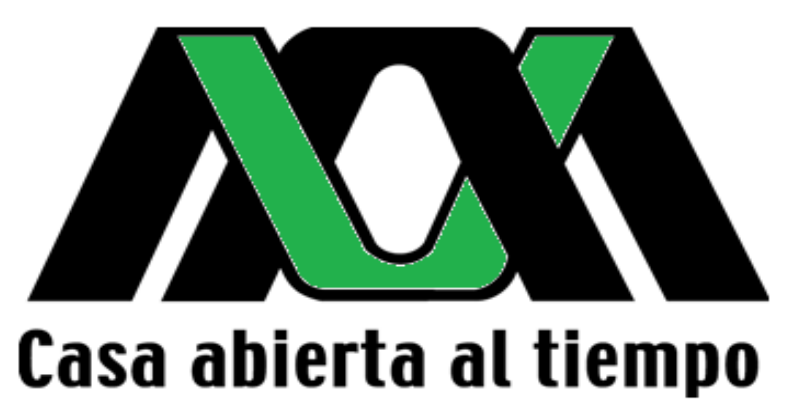
UNIVERSIDAD AUTÓNOMA METROPOLITANA UNIDAD IZTAPALAPA

DIVISIÓN DE CIENCIAS BIOLÓGICAS Y DE LA SALUD DEPARTAMENTO DE BIOTECNOLOGÍA

\section{"Producción de betalaínas en cultivos in vitro de Amaranthaceas"}

TESIS

PARA OBTENER EL GRADO DE

DOCTORA EN BIOTECNOLOGÍA

PRESENTA:

M. en B. E. BERENICE GUADARRAMA FLORES

Director de Tesis: Dr. Francisco Cruz Sosa

Co-Director de Tesis: Dr. Mario Rodríguez Monroy

Asesor: Dr. Fernando Gandía Herrero 
"El Doctorado en Biotecnología de la Universidad Autónoma Metropolitana está incluido en el Programa Nacional de Posgrados de Calidad (PNPC) del CONACYT, con la referencia 001466”.

La firmante de esta Tesis ha disfrutado de una "Beca de Doctorado otorgada por el CONACYT, con número de becario 13587 (septiembre 2011-julio 2015). Durante su estancia en el Centro de Productos Bióticos-IPN (Yautepec, Morelos), se le otorgó la beca de Movilidad Nacional Santander (agosto-diciembre 2012). Para realizar la estancia en la Universidad de Murcia (España), contó con beca Mixta de Movilidad CONACYT, apoyo de la Asociación Universitaria Iberoamericana de Postgrados (AUIP: España) (eneronoviembre 2014) y beca Santander Iberoamérica (enero-junio 2015). 


\section{LUGAR DE REALIZACIÓN:}

Laboratorio de Cultivos de Tejidos Vegetales. Departamento de Biotecnología, Universidad Autónoma Metropolitana-Iztapalapa, San Rafael Atlixco No. 186, Col. Vicentina, C.P. 09340 México, D.F., México.

Laboratorio de Cultivos de Tejidos Vegetales. Departamento de Biotecnología. Centro de Desarrollo de Productos Bióticos (CeProBi). Instituto Politécnico Nacional, Carretera Yautepec-Jojutla, Km. 6, calle CEPROBI No. 8, Col. San Isidro. C.P. 62731. Yautepec, Morelos, México.

Laboratorio de Bioquímica y Biotecnología Enzimática. Departamento de Bioquímica y

Biología Molecular A. Facultad de Veterinaria, Universidad de Murcia, E-30100 Espinardo, Murcia., España. 
División de Ciencias Biológicas y de la Salud de la Unidad lztapalapa aprobó la tesis "Producción de betalaínas en cultivos in vitro de Amaranthaceas"

Que presentó

M. en B. E. Berenice Guadarrama Flores

\section{Comité Tutoral:}

Director: Dr. Francisco Cruz Sosa

Universidad Autónoma Metropolitana-Iztapalapa

Co-Director: Dr. Mario Rodríguez Monroy

Centro de Productos Bióticos-IPN

Asesor: Dr. Fernando Gandía Herrero

Universidad de Murcia

Jurado:

Presidente:

Universidad Autónoma Metropolitana- Iztapalapa

Dr. José Ramón Verde Calvo

Secretario:

Universidad Autónoma Metropolitana- Iztapalapa

Dra. Angélica Román Guerrero

Vocal:

Centro de Investigación Biomédica del Sur-IMSS

Dra. María del Pilar Nicasio Torres

Vocal:

Universidad Autónoma del Estado de México

Dra. María Elena Estrada Zúñiga 


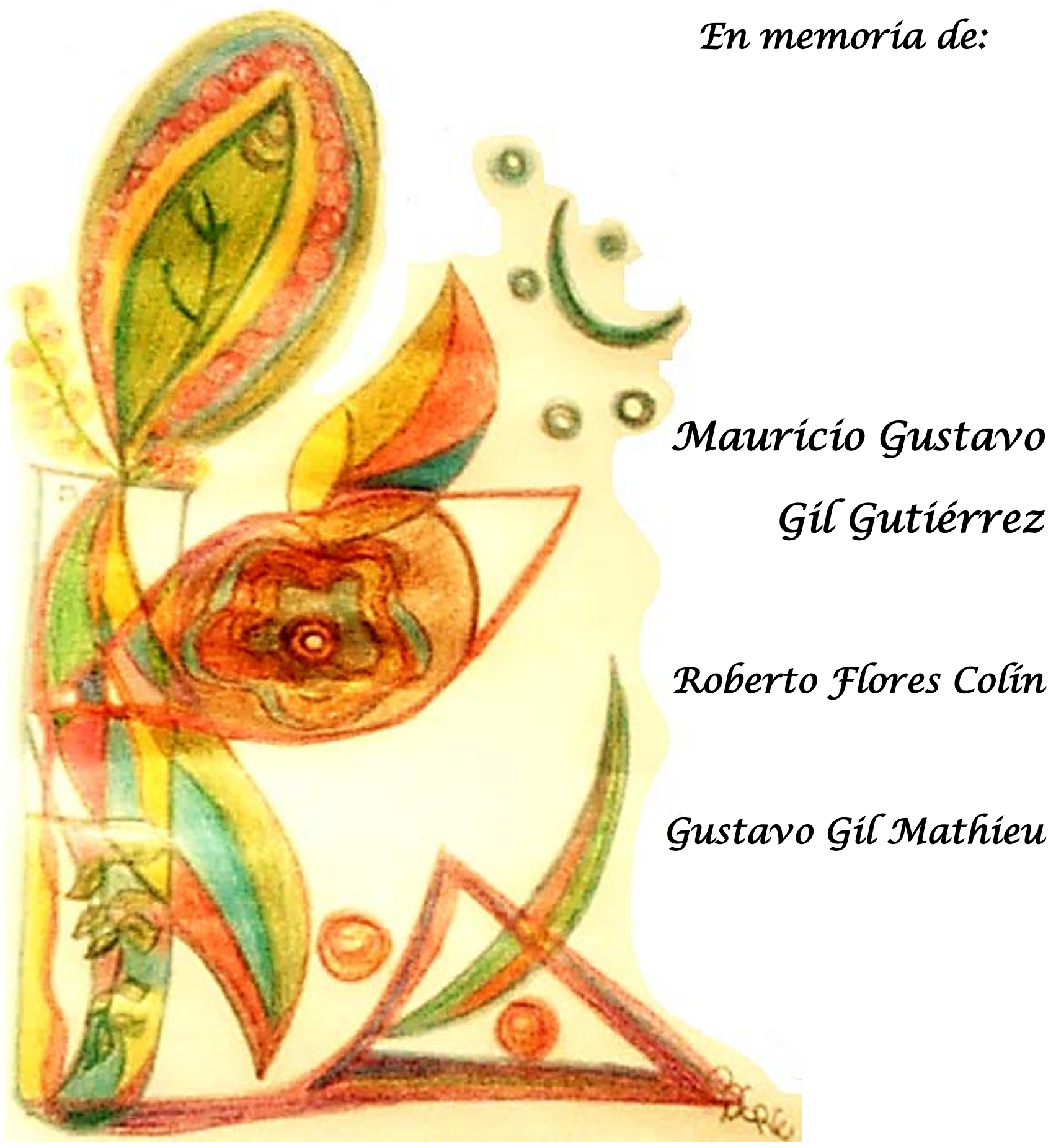

Tres grandes maestros de vida, quíenes día a día síguen compartiéndome su $\mathcal{L U Z}$ 


\title{
Lo esencial es invisible a los ojos...
}

\author{
“El principito”. Antoine De Saint-Exupery
}

En el jardín de la vida he visto muchos caminos y colores. Cada camino me ha llevado a un color y cada color me ha llevado a un camino. Así fue, como siguiendo el color verde, en 2001, llegue a la UAM-I y me albergue “en el agua de las lajas”: Iztapalapa. Entre los pasillos blancos y sinfónicos prados de la Universidad, fui encontrando veredas internas que me llevaron a descubrir otros tantos parajes; como el "lugar alrededor de los tules": Tulyehualco, pueblo ancestral a quién le agradezco haberme compartido sus alegres y coloridos cultivares de amaranto; que a su vez me llevaron a redescubrir el escondido R-003 de la UAM-I, donde en 2010 conocí al Dr. Francisco Cruz Sosa, a quien nunca se lo he contado, pero desde los primeros trimestres de mi llegada a la UAM-I, encontré este sitio y para mis adentros dije - algún día trabajaré allí en "Fitoquimica”, como se llamaba antiguamente este laboratorio. Así nueve años después de mi llegada a la UAM-I conocí al Dr. Cruz Sosa, a quién le agradezco enormemente haberme brindado su confianza y la total libertad de movimiento y acción, dando soporte y apoyo a cada elección de los caminos que fui tocando a través de estos ya casi cinco años de conocernos. Agradezco también a todo su equipo de trabajo, por mostrarme el fascinante mundo in vitro y haberme impulsado a emprender otros tantos viajes. Gracias a todos los que alguna vez formaron o siguen siendo parte de ese equipo: Dra. Leticia Buendía, Dra. Ma. Elena Estrada, Dr. Juan Orozco, Dra. Amalia Maldonado, Maestro Lechuga, Dr. Antonio Bernabé, Alex, Rayn, Lilia, Mireya, May, Alexa, Hypatia, Epson, Aurelio...

La Dra. Micaela de la O Olán del INIFAP, fue quien me proporcionó con la alegría que la caracteriza y de manera desinteresada las semillas y los ejemplares de amaranto, mil gracias doctora por confiar en un proyecto que apenas iniciaba y de cuya existencia usted no tenía conocimiento. Fue en el laboratorio de Biotecnología Vegetal de la UAM-I, donde sobre una solución compleja y nutritiva, planté esas semillas de amaranto, de las cuales comenzó a surgir la radícula que se fue ramificando por diferentes rincones del mundo; su color amarillento me llevo a conocer y a vivir "en el cerro del pericón": Yautepec, donde entre cañaverales verdes, mariposas blancas, buganvilias violetas, cuijas ocres, arroyos grisáceos y árboles de cuaguayote; oculto entre la Barranca Honda, encontré en 2012 el CeProBi. En CeProBi, me abrazo con cariño el grupo de Investigación de Biotecnología Vegetal del Dr. Mario Rodríguez Monroy y de su esposa Gabriela Sepúlveda Jiménez, a quienes les agradezco infinitamente su tiempo, su confianza, su amistad, su solidaridad y todos sus conocimientos compartidos. En ese clima tan cálido aprendí el valor de los amigos, de las palabras, las sonrisas, el tiempo compartido y de no olvidar incluir el postre en la vida. Gracias de todo corazón a mis amigas y hermanas Leticia Pavón Reyes y Jaqueline Téllez Vargas por acompañar mi crecimiento en todo este tiempo. Gracias a Jorge Cantor, Humberto Reyes, Rafael Garibay, Roberto Sibaja, Laura Chiquiza, la maestra “Toñita”, la maestra Sandra, el Sr. Homero, Paul, Sandra...

Así paso a paso, en ese ir y venir de vida, cruce el océano. La misteriosa “mancha amarilla” proveniente del cultivo de amaranto, me llevo a mirar como amanece y anochece en el "lugar donde crecen los mirtos”: Murcia. En la Huerta de Europa que viste su aire de naranjas y rosas, un 
día nublado y ventoso de enero del 2014, conocí a mi “profesor” el Dr. Fernando Gandía Herrero, investigador y amigo, quien sin saberlo me devolvió la creencia de que las cosas grandes pueden lograrse con trabajo y mucha fe; día a día me compartió la fascinación de abrirme al conocimiento soltando los miedos y los prejuicios, disfrutando cada instante del presente - "en todo proceso de purificación siempre existen perdidas”- me decía mientras eluíamos el pigmento amarillo en una C-18. "Profesor" mil gracias por cada palabra y cada vivencia, las cuales como semillas de celosía lograron germinar en mí, desdiferenciarse, crecer y adquirir las tinturas de la abundancia y la riqueza: el color amarillo y el color rojo. Estoy infinitamente agradecida con cada uno de los integrantes del Departamento de Bioquímica y Biología Molecular A, de la UM. Gracias a las nutritivas clases en el pasillo o frente a la cámara de cultivo del Dr. Francisco García Carmona, que siempre me ayudaron a ver lo que aún no se materializaba. Gracias a las sonrisas y el apoyo de las Dras. Juana Cabanes, Josefa Escribano, Mercedes Jiménez, Manuela Pérez y María Inmaculada García. Gracias a la amabilidad de los Dres. Álvaro Ferrer y José Manuel López. Mi más sincero agradecimiento a Liliana Castro, quien me abrió las puertas de su casa a mi llegada a Murcia. A Ana Belén Martínez Moñino, le agradezco profundamente su sonrisa cálida, su confianza, su alegría y su apoyo en todo momento, gracias guapa!! Agradezco también la camaradería de Rubén Zapata, Antonio, Samanta, Adrián, José Eduardo y claro mi amigo y paisano Luis Eduardo Contreras “Lalo”. Agradezco infinitamente a la Dra. Miguela Iniesta Moreno y a su esposo el Dr. Francisco Balibrea Gallego, por integrarme a sus vidas de manera tan familiar y franca, por brindarme un lugar cálido y acogedor en su piso, gracias por cada uno de sus detalles. Gracias a todos por ayudarme a construir el matiz de cada instante, en tierras levantinas. MIL GRACIAS!!

Mi total reconocimiento al jurado de esta Tesis Doctoral, por todo su tiempo y dedicación para ofrecerme sus aportaciones, comentarios y sugerencias, las cuales enriquecieron la calidad del documento. Deseo agradecer también al Dr. Francisco Fernández Perrino y al Dr. Héctor Escalona Buendía ambos en tiempos distintos, coordinadores del Posgrado en Biotecnología y a la Lic. Violeta Luna Caballero, gracias a todos por su amabilidad y por facilitarme cada trámite requerido por la UAM-I y CONACYT; instituciones a quienes les agradezco profundamente la oportunidad que me han dado de alcanzar objetivos académicos y de vida.

Agradezco a todas las personas y las vivencias de mi pasado, especialmente a Mauricio Gustavo Gil Gutiérrez quien me ayudo a recorrer, descubrir y construir por más de una década una parte sustancial de mi paisaje interno. Gracias a la familia Gil Gutiérrez por la luz que me brindaron, a Don Gustavo Gil Mathieu por regalarme la oportunidad de ver con más claridad el mundo. Sin este pasado los soles y las lunas de mi presente simplemente no brillarían.

Agradezco a todos los arcanos que día a día han ido apareciendo en mi vida, pues a través de su reflejo me han ayudado a edificar mi conciencia. Gracias a Jaqueline Moreno Cabrera por estos casi 14 años de vivencias y desarrollo en conjunto. Gracias a Verónica Murillo, Martha Juárez Ciriaco, Leticia Rodríguez, mi amigo Juan, David, “El joven”; a todos ellos por revelarme a través de su valentía mi propia valentía. Gracias a María del Carmen Díaz Maroto por mostrarme el "para qué” de las emociones. Gracias a mi "Caco Fatimí”, a Laura Marroquín y a todo el "Tablao Flamenco Solera San Miguel” por manifestar la simpleza y el arte del vivir. Gracias a Lourdes Casales y a todos los "Regaladores de palabras" del Museo Universitario del Chopo, UNAM, por permitirme 
compartir a través de la voz y la mímica, los cuentos que fueron renovando y avivando el interior de mi templo. Gracias a Javi Soto y a todos mis compañeros del Taller "Impro-vivencia: Murcia”, por mostrarme la fuerza y la voluntad del "acepta y sigue” del constante cambio. Gracias a todos los integrantes del taller de Radio de Fundación Cattell, por ayudarme a cumplir un sueño de infancia: ir a la radio y transmitir a través del espectro electromagnético. Gracias a Juan Pedro Barquero y a los poetas que conocí en Murcia, por creer en la poesía, ponerla en acción y permitirme ser parte de esta acción.

A través de este tiempo he comprendido que "lo que el árbol tiene de florido, vive de lo que tiene sepultado"* por ello quiero agradecer a las raíces que me dan forma. Mis abuelos y abuelas que transitaron y aún recorren su tiempo a tiempo. A mis padres fruto de ese tiempo y alquimistas de mi vida. A mi madre Juana quien sembró en mí, las innumerables semillas que dan flores y frutos de acuerdo a cada estación. A mi padre Teo quien abona mi tierra y pone escaleras para alcanzar sueños. A mis hermanos poseedores de la voluntad que cristaliza visiones. A mi hermana Anayantzi cuyo significado de su nombre "la llave de la felicidad" encierra lo que sólo ella nos hace descubrir al tocar nuestros instantes. A mi hermano Héctor Lenin, guerrero de luz y a su esposa Ruth, ambos poseedores de una clara mirada del universo. A mi tío Beto, quien en vida nos expresó que para sembrar se necesita alegría y ya habiendo partido nos revela que para cosechar se necesita amor y gentileza por el suelo labrado. A la niña de mi infancia, quien aún juega gustosa en el jardín de casa, a extraer el color del tiempo guardado en los pétalos de flores y las nervaduras de las hojas; es ella quien ha mantenido la alegría y la fuerza en mi interior, quien posee las cerraduras para abrir cada puerta que se obstruye, llenando los bolsillos de tardes, nubes y preguntas.

Todos somos viajeros lo sepamos o no. Caminamos la vida encontrando universos peregrinos. En esta danza mística la luz me envío un maestro, seguramente un compañero de vida quien con su música, sabe encontrar en mí la calma y como caracol modela el murmullo de las cosas -“sólo escucha la vida"- me dice, - "toma mi mano y caminemos"-. Gracias por tanta luz Francisco "Paco", mi Paco Mares.

Finalmente agradezco la bondad y la sabiduria de la naturaleza con todo su misterio y abundancia, sus plantas, sus ramas, sus ríos y sus cielos, envueltos de unidad y armonía; pues es en la naturaleza en donde vivimos nuestro presente y todo lo que en el habita "aquí y ahora”. Ha sido mirando la naturaleza donde he comprendido que la vida es una extensión de mi misma, que los Ciclopes que se levanten ante mí, serán tan poderosos y astutos como sólo mi mente pueda fabricarlos, y me ha hecho entender que sólo yo tengo el poder para desarmarlos y deshacerlos. Porque yo soy lo que "creo" que soy. Cada día desde el ahora, sujeto con fuerza mis pasos, siendo dueña de mi tiempo y construcción de mis sueños...

*Fragmento del poema “sólo Dios basta” de Santa Teresa de Ávila. 


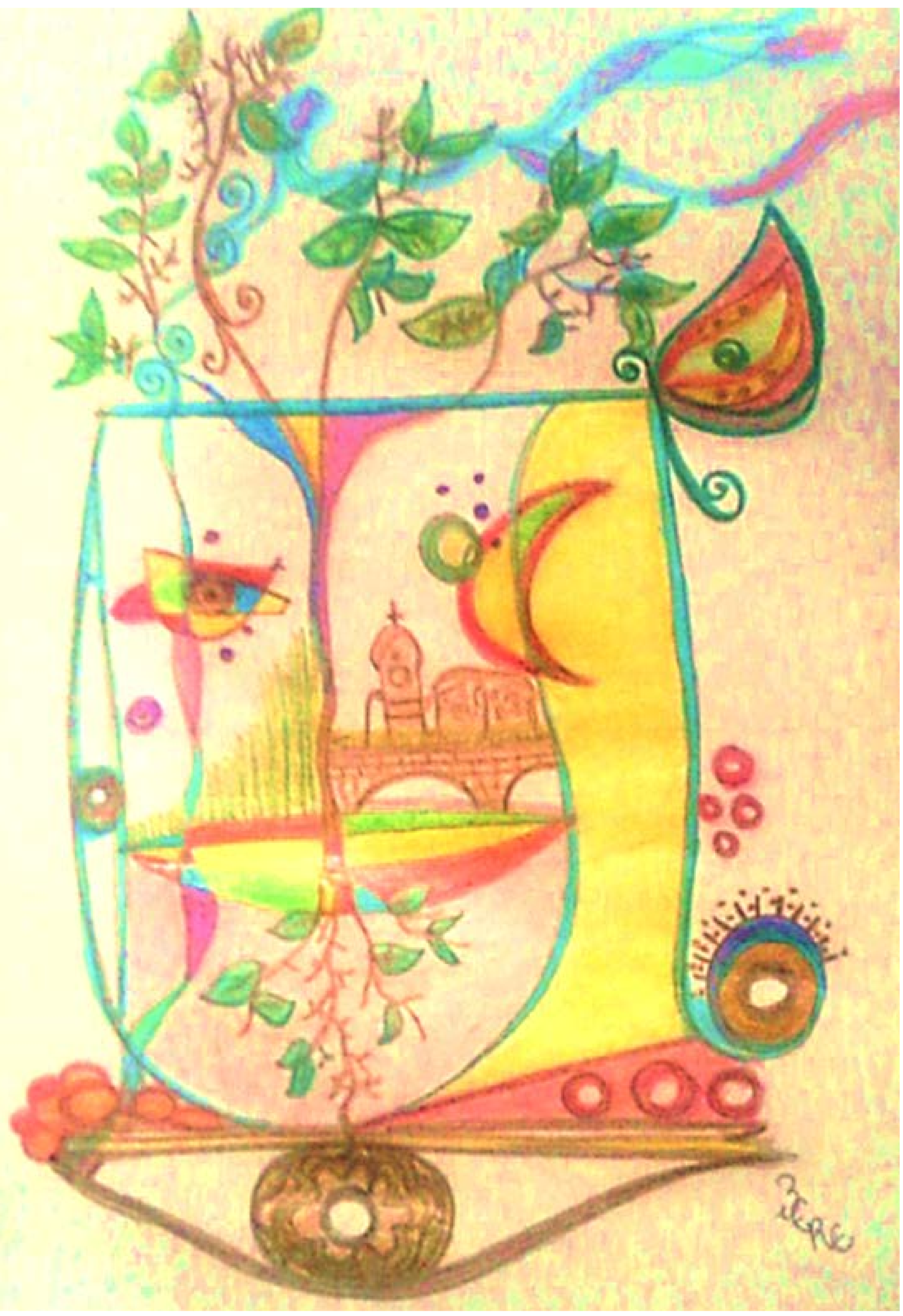




\section{PRÓLOGO}

En el presente trabajo, Tesis Doctoral titulada "Producción de betalaínas en cultivos in vitro de Amaranthaceas”, se abordó el estudio y análisis de dos especies vegetales: Amaranthus hypochondriacus variedad nutrisol y Celosia argentea variedad plumosa.

La tesis está dividida en diez capítulos. El primero, introduce al lector al documento. El segundo es una revisión crítica de la bibliografía escrita sobre el tema. En el tercero se expone la justificación del trabajo. El capítulo 4 engloba los materiales y métodos empleados para el estudio de las dos especies vegetales, ya que en la mayoría de los casos los procedimientos metodológicos empleados fueron los mismos.

El capítulo 5 está dedicado exclusivamente a Amaranthus hypochondriacus variedad nutrisol, cuenta con una tabla de contenido gráfico, que ilustra de manera visual lo alcanzado para esta especie y complementa el resumen y el abstract de este capítulo. Se presenta la hipótesis y los objetivos específicos planteados para el estudio de esta planta en concreto, mostrándose los resultados conseguidos, la discusión de los mismos y finalmente las conclusiones. El capítulo 6 está designado concretamente a Celosia argentea variedad plumosa, de igual manera que en el caso anterior, este capítulo cuenta con tabla de contenido gráfico, resumen, abstract, hipótesis, objetivos, resultados, discusión y conclusiones; siendo abordados todos estos apartados de forma delimitada para esta especie.

\section{Berenice Guadarrama Flores}


La conclusión general del trabajo se despliega en el capítulo 7, la cual mediante una figura integra todos los compuestos producidos en las líneas celulares de $A$. hypochondiacus variedad nutrisol y de C. argentea variedad plumosa. En el capítulo 8 se exponen las perspectivas de investigación futura que podrían abordarse a partir de los resultados derivados de esta tesis. La bibliografía consultada para el sustento de este documento se encuentra contenida en el capítulo 9. Finalmente en el capítulo 10, se presenta la publicación emanada de este trabajo de tesis doctoral, la cual corresponde a los resultados obtenidos para C. argentea, expuestos previamente en el capítulo 6. Actualmente se trabaja en la elaboración del artículo que englobará los resultados obtenidos para $A$. hypochondriacus expuestos en el capítulo 5. 


\section{RESUMEN GENERAL}

El color y la apariencia son las primeras características que el consumidor evalúa al adquirir un producto. Actualmente se observa una creciente restricción en el uso de colorantes sintéticos para el consumo humano, por problemas de toxicidad, reacciones alérgicas y de intolerancia. Esto ha favorecido la incorporación de tinturas naturales en el mercado global de colorantes. Las betalaínas son pigmentos hidrosolubles de color violeta (betacianinas) y amarillo (betaxantinas), estables a pH ácido; con actividad antioxidante, antiinflamatoria, anti-carcinogénica y neuroprotectora; considerándose sustancias nutracéuticas. Amaranthus hypochondriacus variedad nutrisol y Celosia argentea variedad plumosa biosintetizan betalaínas. El presente trabajo es el primer informe sobre el establecimiento de líneas celulares de callo y suspensión de ambas amarantáceas, obtenidas en medio Murashige y Skoog suplementado con BAP 6.66 $\mu \mathrm{M}$ y 2,4-D $6.79 \mu \mathrm{M}$. Las líneas celulares de estas dos especies produjeron betalaínas; en amaranto para tal efecto los cultivos fueron sometidos a envejecimiento, elicitación y biotransformación. Las células en suspensión de ambas plantas mostraron mayor producción de betalaínas con respecto a las de callo, caracterizándose betacianinas como betanina, betanidina, amarantina; y betaxantinas como glutamina-betaxantina, dopa-betaxantina, dopamina-betaxantina, triptófano betaxantina; y ácido betalámico. En celosía se obtuvieron altas concentraciones de dopamina, lográndose la encapsulación preliminar de todos los compuestos con maltodextrina, mediante secado por pulverización. De esta manera se evidencia la capacidad celular de estos cultivos para convertirse en fuentes de colorantes biactivos y valiosos fitoquímicos con alto potencial de aplicación en la industria alimentaria, farmacéutica y cosmética.

\section{Berenice Guadarrama Flores}




\section{GENERAL ABSTRACT}

The color and appearance are the first features that the consumer evaluates to purchase a product. There is a growing increase in restricting the use of dyes for human consumption, due to problems of toxicity, allergic reactions and intolerance. This has favored the incorporation of natural pigments in the global market of dyes. Betalains are water soluble pigments of red-purple color (betacyanins) and yellow color (betaxanthins), stable at acid $\mathrm{pH}$, that have antioxidant, anti-inflammatory, anti-carcinogenic and neuroprotective activities, regarded as nutraceuticals. Amaranthus hypochondriacus var. nutrisol and Celosia argentea var. plumosa synthesized betalains. This work presents the first report on the establishment of cell lines callus and in vitro suspension cultures of both Amaranthaceae in Murashige and Skoog medium supplemented with BAP $6.66 \mu \mathrm{M}$ and 2,4-D 6.79 $\mu \mathrm{M}$. Cell lines of these two species produced betalains; to that effect in the cultures of amaranth were subjected to aging, elicitation and biotransformation. In both cell suspension cultures for both plant species, the betalain production was higher than the callus, characterized betacyanins as betanin, betanidin, isobetanidin, amaranthin, isoamaranthin; and betaxanthins as glutamine-betaxanthin, dopa-betaxanthin, dopaminebetaxanthin, tryptophan betaxanthin and betalamic acid. In the case of celosia high concentrations of dopamine were also achieved and the preliminary encapsulation of all compounds was obtained with maltodextrin by spray drying. This evidenced the capacity of these cell cultures to become sources of dyes and valuable bioactive phytochemicals with high potential for application in the food, pharmaceutical and cosmetic industries.

\section{Berenice Guadarrama Flores}




\section{ABREVIATURAS}

ABTS

ANA

BAP

B5

CFR

COX-2

CTV

2,4-D

DODA

EFSA

EGCG

ESI-MS

FDA

FRAP

HPLC

HPLC-DAD

INIFAP

L-DOPA

$\lambda_{\mathbf{m}}$

LOX-1 ácido 2,2'-azino-bis 3-etilbenzotiazolina-6-sulfónico

ácido naftalenacético

6-bencilaminopurina

medio Gamborg

código de regulaciones federales

ciclooxígenasa 2

cultivo de tejidos vegetales

2,4-diclorofenoxiacético

4,5-DOPA-extradiol-dioxigenasa

agencia de seguridad alimentaria de la unión europea

galato de epigalocatequina

análisis de espectrometría de masas con ionización por electrospray

administración de alimentos y medicamentos

poder antioxidante reductor del hierro

cromatografía líquida de alta resolución

cromatografía líquida de alta resolución con arreglo de diodos

instituto nacional de investigaciones forestales y agropecuarias

3,4-didhidroxifenilalanina

longitud de onda máxima

lipooxigenasa 1

Berenice Guadarrama Flores 
$\boldsymbol{\mu}$

MeJA

$[\mathbf{M}+\mathbf{H}]^{+}$

mRNA

MS

MS/MS

MYB

$\boldsymbol{m} / \mathrm{z}$

nm

pH

RCV

RMN

RP-HPLC

SA

SNPs

TEAC

TFA

$T_{r}$ tasa de crecimiento

metiljasmonato

valores de masa para los iones moleculares protonados

ácido ribonucleico mensajero

medio Murashige \& Skoog

espectrometría de masas / masas

factor de transcripción de antocianinas

relación carga masa

nanómetros

potencial de Hidrogeno

reguladores de crecimiento vegetal

resonancia magnética nuclear

cromatografía líquida de alta resolución de fase reversa

ácido salicílico

polimorfismos de un sólo nucleótido de vinculación

capacidad antioxidante equivalente de Trolox

ácido trifluoroacético

tiempo de retención 


\section{ÍNDICE GENERAL}


PRÓLOGO

RESUMEN GENERAL

GENERAL ABSTRACT IV

ABREVIATURAS

ÍNDICE GENERAL

ÍNDICE DE TABLAS XIV

$\begin{array}{ll}\text { ÍNDICE DE FIGURAS } & \text { XVI }\end{array}$

Capítulo 1: INTRODUCCIÓN $\quad 2$

Capítulo 2: ANTECEDENTES

I. Pigmentos de las Caryophyllales $\quad 5$

II. Características generales de las betalaínas 9

1. Estructura química 9

A. Isómeros estructurales 11

2. Propiedades ópticas 12

$\begin{array}{ll}\text { 3. Actividad biológica } & 17\end{array}$

III. Biosíntesis de las betalaínas $\quad 19$

$\begin{array}{ll}\text { 1. Enzimas clave } & 20\end{array}$

2. Formación de ácido betalámico 21

3. Formación de betalaínas 23 
4. Reacciones en betacianinas

5. Formación de betalaínas descarboxiladas

IV. Betalaínas: colorantes naturales nutracéuticos

1. Colorantes

2. Aplicaciones industriales

3. Estabilidad

V. Producción de betalaínas en cultivos in vitro de plantas

1. Composición del medio de cultivo

2. Precursores y elicitores

3. Influencia de la luz

4. Sistemas de cultivo establecidos

VI. Betalaínas en la familia Amaranthaceae

2. Celosia argentea

Capítulo 3: JUSTIFICACIÓN

I. Reactivos

II. Material vegetal

III. Desinfección y germinación de semillas

IV. Inducción de callo

V. Establecimiento de suspensiones celulares 
VI. Cultivo de suspensiones celulares de A. hypochondriacus en biorreactor de $3 \mathrm{~L}$

VII. Cinéticas de crecimiento

VIII. Viabilidad celular

IX. Envejecimiento de líneas celulares de $A$. hypochondriacus

$X$. Adición de precursores y elicitores en líneas celulares de $A$. hypochondriacus

XI. Extracción y purificación del pigmento amarillo de A. hypochondriacus

XII. Extracción de betalaínas

XIII. Estándares de betalaínas

XIV. Cromatografía de intercambio aniónico

XV. Extracción de betalaínas en fase sólida con cartuchos C-18

XVI. Análisis por HPLC-DAD

XVII. Espectrometría de masas con ionización por elecrospray

XVIII. Espectrometría de fluorescencia del pigmento amarillo de A. hypochondriacus

XIX. Espectroscopía UV-Vis

XX. Microscopía

XXI. Encapsulación de betalaínas y dopamina en cultivos in vitro de $C$. argentea

XXII. Análisis estadístico 
Capítulo 5: PRODUCCIÓN DE BETALAINAS EN CULTIVOS

IN VITRO DE Amaranthus hypochondiacus

II. RESUMEN

III. ABSTRACT

IV. HIPÓTESIS

V. OBJETIVOS

$\begin{array}{ll}\text { VI. RESULTADOS Y DISCUSIÓN } & 76\end{array}$

1. Establecimiento de cultivo aséptico 76

2. Obtención de líneas celulares de callo de $\boldsymbol{A}$. hypochondriacus 76

3. Cultivos en suspensión a nivel de matraz y biorreactor de 3L 80

4. Caracterización parcial del pigmento amarillo 83

5. Inducción de la biosíntesis de betalaínas en líneas in vitro 86

$\begin{array}{ll}\text { A. Envejecimiento del cultivo } & 87\end{array}$

B. Adición de elicitores $\quad 89$

$\begin{array}{ll}\text { C. Adición de precursores } & 93\end{array}$

D. Influencia general de la respuesta al estrés abiótico y adición de precursores

VII. CONCLUSIONES 
Capítulo 6: PRODUCCIÓN DE BETALAINAS EN CULTIVOS IN VITRO DE Celosia argentea

101

I. TABLA DE CONTENIDO GRÁFICO

II. RESUMEN

103

III. ABSTRACT

IV. HIPÓTESIS

V. OBJETIVOS

106

VI. RESULTADOS Y DISCUSIÓN

1. Obtención de líneas celulares de callo de Celosia argentea

2. Identificación del pigmento en líneas celulares amarillas y rojas

3. Cultivos en suspensión de $C$. argentea

4. Producción de betalaínas y dopamina en cultivos en suspensión de $C$. argentea

5. Encapsulación preliminar de betalaínas y dopamina

VII. CONCLUSIONES

Capítulo 7: CONCLUSIÓN GENERAL

Capítulo 8: PERSPECTIVAS

Capítulo 9: BIBLIOGRAFÍA 


\section{ÍNDICE DE TABLAS Y FIGURAS}




\section{ÍNDICE DE TABLAS}

\section{Capítulo 2}

Tabla 1. Betaxantinas de origen natural identificadas estructuralmente en las plantas

Tabla 2. Principales especies vegetales productoras de betalaínas

Tabla 3. Producción de betalaínas en cultivos in vitro de plantas

Tabla 4. Estructura química y betacianinas del tipo amarantina identificadas en Amaranthaceae

Tabla 5. Estructura química y betacianinas del tipo gomfrenina, betanina y betaxantinas identificadas en Amaranthaceae

\section{Capítulo 5}

\section{TABLA DE CONTENIDO GRÁFICO Amaranthus hypochondriacus}

Tabla 6. Porcentaje de contaminación obtenido durante la desinfección de semillas de Amaranthus hypochondriacus var. nutrisol

Tabla 7. Efecto de los reguladores de crecimiento vegetal (RCV), sobre la inducción de callos a partir de explantes de hoja de A. hypochondriacus var. nutrisol, después de 30 días de cultivo

Tabla 8. Producción de betalaínas y ácido betalámico en células de la línea de callo de Amaranthus hypochondriacus, sometida a estrés abiótico por envejecimiento del cultivo

Tabla 9. Producción de betalaínas y ácido betalámico en células de la línea de callo y en cultivos en suspensión de Amaranthus hypochondriacus, sometidas a estrés abiótico por elicitación con $100 \mu \mathrm{M}$ de MeJA y $10 \mathrm{mM}$ de SA 
Tabla 10. Producción de betalaínas y ácido betalámico en células de la línea de callo y en cultivos en suspensión de Amaranthus hypochondriacus, al añadir $1.5 \mathrm{mM}$ de tirosina y L-DOPA

\section{Capítulo 6}

I. TABLA DE CONTENIDO GRÁFICO Celosia argentea

Tabla 11. Efecto de los reguladores de crecimiento vegetal (RCV), sobre la inducción de callos a partir de explantes de hipocótilos de Celosia argentea var. plumosa, después de 30 días de cultivo

Tabla 12. Producción de betalaínas, dopamina y ácido betalámico en células de las líneas de callo amarilla y roja y en cultivos en suspensión de $C$. argentea

Tabla 13. Producción de betalaínas, dopamina y ácido betalámico en el medio líquido de cultivos en suspensión de $C$. argentea 


\section{ÍNDICE DE FIGURAS}

\section{Capítulo 2}

Figura 1. Orden Caryophyllales

Figura 2. Regulación positiva del gen BvMYB1 en Beta vulgaris

Figura 3. Estructuras generales del ácido betalámico, betaxantinas y betacianinas

Figura 4. Estructura de resonancia de las betalaínas

Figura 5. Estructura de los diateroisómeros de betacianinas

Figura 6. Propiedades ópticas de las betalaínas

Figura 7. Efecto de filtro interno y patrones de contraste de fluorescencia

Figura 8. Mecanismo propuesto para la síntesis y almacenamiento de betalaínas en el interior de la célula

Figura 9. Esquema completo de la ruta de biosíntesis de betalaínas

Figura 10. Encapsulados de betalaínas

Figura 11. Producción de betalaínas en sistemas in vitro

Figura 12. Cultivo de raíces transformadas de Beta vulgaris

Figura 13. Amarantus hypochondriacus

Figura 14. Celosia argentea 


\section{Capítulo 5}

Figura 15. Características fenotípicas del explante de hipocótilo y callos inducidos en explantes de hoja de A. hypochondriacus, a los 30 días de cultivo

Figura 16. Establecimiento de líneas celulares in vitro derivadas de A. hypochondriacus

Figura 17. Curva de crecimiento para el cultivo de A. hipochondriacus, en suspensión a nivel de matraz y biorreactor de 3L

Figura 18. Perfil cromatográfico del pigmento amarillo obtenido de los cultivos in vitro de A. hypochondriacus

Figura 19. Espectros de fluorescencia de emisión y excitación del pigmento amarillo presente en las líneas celulares in vitro de $A$. hypochondriacus

Figura 20. Perfiles cromatográficos y espectros de masas de las fracciones purificadas por HPLC, del pigmento amarillo obtenido de los cultivos in vitro de $A$. hypochondriacus

Figura 21. Producción de ácido betalámico y betalaínas en la línea celular de callo de Amaranthus hypochondriacus variedad nutrisol, durante el envejecimiento del cultivo

Figura 22. Producción de ácido betalámico y betalaínas en la línea celular de callo y suspensión de Amaranthus hypochondriacus variedad nutrisol, al adicionar $100 \mu \mathrm{M}$ de MeJA y 10 mM de ácido salicílico.

Figura 23. Evolución temporal de las características fenótipicas del cultivo en suspensión y de callo de Amaranthus hypochondriacus variedad nutrisol, al adicionar $100 \mu \mathrm{M}$ de MeJA y $10 \mathrm{mM}$ de SA

Figura 24. Producción de ácido betalámico y betalaínas en la línea celular de callo y suspensión de Amaranthus hypochondriacus variedad nutrisol, al adicionar $1.5 \mathrm{mM}$ de tirosina y L-DOPA 
Figura 25. Evolución temporal de las características fenótipicas del cultivo en suspensión y de callo de Amaranthus hypochondriacus variedad nutrisol, al adicionar $1.5 \mathrm{mM}$ de tirosina.

Figura 26. Evolución temporal de las características fenótipicas del cultivo en suspensión y de callo de Amaranthus hypochondriacus variedad nutrisol, al adicionar $1.5 \mathrm{mM}$ de L-DOPA.

Figura 27. Influencia general de respuesta al estrés abiótico y a la adición de precursores sobre la ruta de biosíntesis de betalaínas en las líneas in vitro de A. hypochondriacus

\section{Capítulo 6}

Figura 28. Características fenotípicas de callos inducidos en explantes de hipocótilos de Celosia argentea variedad plumosa a los 30 días de cultivo

Figura 29. Establecimiento de líneas celulares in vitro derivadas de C. argentea var. plumosa

Figura 30. Micrografía de las células de la línea de callo amarillo de $C$. argentea

Figure 31. Producción de betalaínas y dopamina por las líneas celulares derivadas de C. argentea var. plumosa

Figura 32. Curva de crecimiento para el cultivo en suspensión de C. argentea

Figura 33. Encapsulados de betalaínas y dopamina de cultivos de callo de C. argentea

\section{Capítulo 7}

Figura 34. Estructuras de betalaínas obtenidas en cultivos in vitro de $A$. hypochondriacus variedad nutrisol y $C$. argentea variedad plumosa 
Capítulo 1. INTRODUCCIÓN 


\section{INTRODUCCIÓN}

Se estima que el $25 \%$ de medicamentos, cosméticos, esencias aromáticas, saborizantes y colorantes utilizados en los países desarrollados provienen de metabolitos secundarios de plantas silvestres o cultivadas (Ramesh et al., 2013). Los metabolitos secundarios generalmente se producen en condiciones de estrés en un tipo particular de células y en pequeñas cantidades. El cultivo de células vegetales es una alternativa biotecnológica que permite optimizar la producción de compuestos químicos de interés como las betalaínas de forma aséptica, continua, en una superficie pequeña y bajo condiciones controladas. Habitualmente se utiliza la citocinina BAP y la auxina 2,4-D, para inducir la formación de cultivos de callo rojo y amarillo, y mantener suspensiones pigmentadas de muchas plantas Caryophyllales como Beta vulgaris, así como otras especies de amarantáceas (Georgiev et al., 2008; Karuppusamy, 2009).

Amaranthus hypochondiacus var. nutrisol, especie originaria de México y Celosia argentea var. plumosa, son herbáceas anuales pertenecientes a la familia Amaranthaceae. Se encuentra documentado el uso medicinal y ornamental para estas dos plantas; en el caso particular del amaranto, éste se cultiva para la obtención de pseudocereales con alto valor nutritivo. Ambas especies vegetales producen betalaínas, pigmentos naturales que contienen nitrógeno y proporcionan coloración brillante a las frutas, flores, hojas y raíces de la mayoría de Caryophyllales (Moreno et al., 2008). Las betalaínas se dividen en dos 
grupos: las betacianinas de color violeta, con espectros de absorbancia centrados en 536 nm, y las betaxantinas de color amarillo, con espectros de absorbancia centrados en 480 nm. Ambos grupos comparten al ácido betalámico como unidad estructural y cromóforo, que se condensa con ciclo-DOPA en las betacianinas y con aminas y aminoácidos en las betaxantinas (Gandía-Herrero y García-Carmona, 2013). Las betalaínas son solubles en agua y poseen actividad nutracéutica a concentraciones muy bajas, por lo que resulta viable su uso como colorante natural bioactivo (Kapadia et al., 2003; Lu et al., 2009; Lechner et al., 2010; Gandía-Herrero et al., 2013; Ravichandran et al., 2014; Janiszewska, 2014; Robert et al., 2015).

Actualmente no existen reportes con respecto al establecimiento de cultivos celulares de Amaranthus hypochondiacus var. nutrisol y de Celosia argentea var. plumosa, para la producción de colorantes, por lo que el objetivo principal del presente trabajo fue establecer cultivos in vitro de ambas especies para evaluar su capacidad de producción de betalaínas y caracterizar dichos pigmentos. 
Capítulo 2. ANTECEDENTES 


\section{ANTECEDENTES}

Junto con la fragancia, la forma y el tamaño de la planta, los pigmentos desempeñan un papel clave en la biología de las angiospermas, actúan como señales visibles para la polinización, dispersión de semillas, así como protección al estrés por luz, fitopatógenos; además están involucrados en diferentes rutas de señalización interna. Los pigmentos vegetales más comunes son los carotenoides, clorofilas, antocianinas y betalaínas. Mientras que las antocianinas participan en la coloración de todos los miembros de las angiospermas, las betalaínas se han restringido al linaje de los hongos Basidiomycetes y de las plantas Caryophyllales, impartiendo en estas una gama de colores amarillos, anaranjados, violetas y rojos en raíces, hojas, flores, frutos y semillas (Stintzing y Carle, 2004; Brockington et al., 2011).

\section{Pigmentos de las Caryophyllales}

El orden Caryophyllales (Figura 1) es un clado bien definido de Eudicotyledoneae, comprende alrededor de 29 familias y 9.000 especies (APG, 2003). Este orden, es muy heterogéneo, incluye amarantáceas como Amaranthus hypochondriacus (B), Celosia argentea (C), Beta vulgaris (D); cactáceas como Opuntia ficus-indica (E); nictagináceas como Bougainvillea glabra (F); cariofiláceas como Silene dioica (G); portulacáceas como Portulaca oleracea $(\mathrm{H})$, entre los taxones y especies más representativos. Comprende 
familias que producen sólo antocianinas o sólo betalaínas, no se conocen especies que sinteticen ambos pigmentos. No obstante en dos familias de éste orden, la Molluginaceae y Caryophyllaceae, se producen antocianinas en lugar de betalaínas, lo que indica que estos pigmentos son mutuamente excluyentes (Brockington et al., 2011).

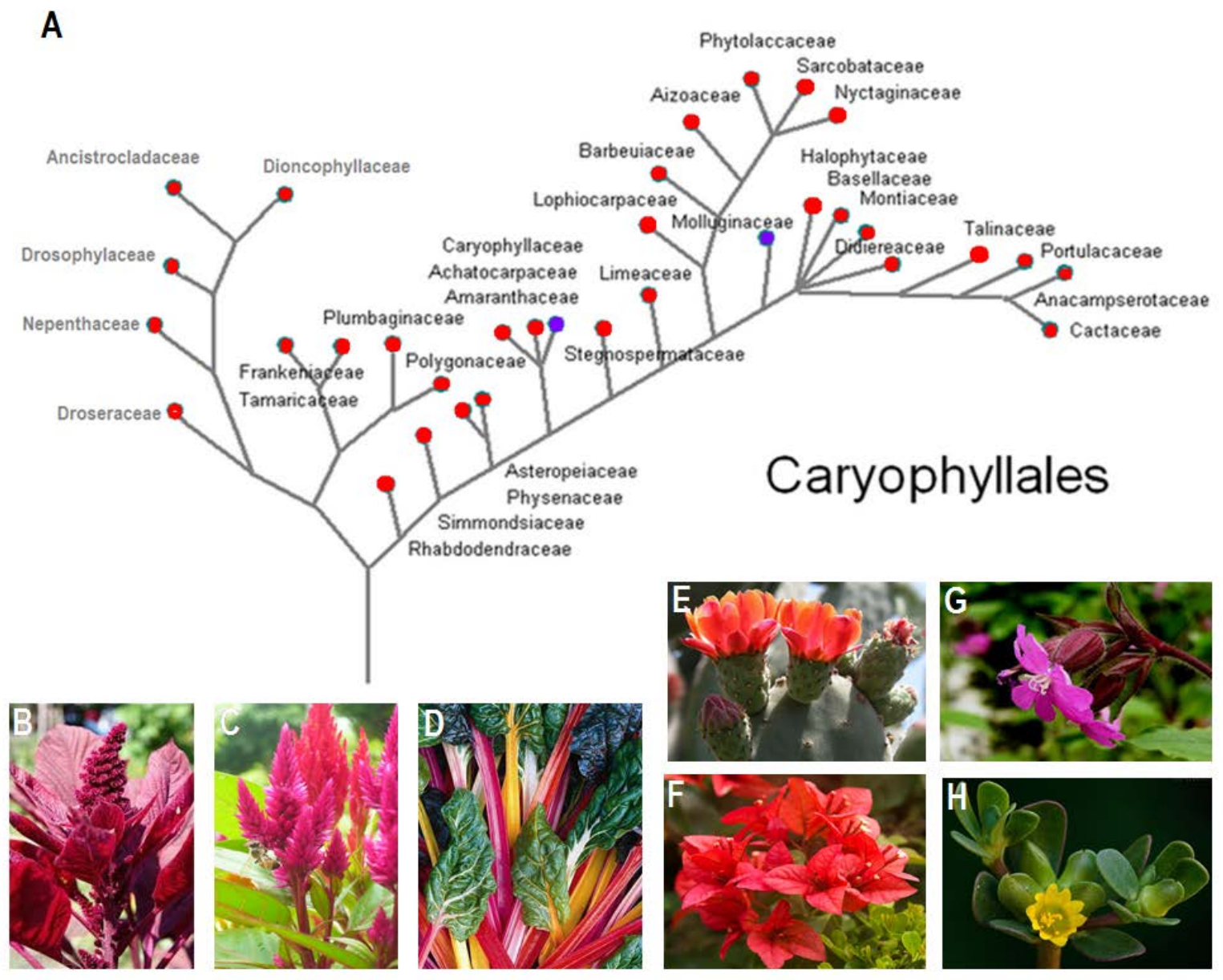

Figura 1. (A) Orden Caryophyllales: círculos de color rojo: pigmentación por betalaínas, círculos morados: pigmentación por antocianinas. (B) Amaranthus hypochondriacus. (C) Celosia argentea. (D) Beta vulgaris. (E) Opuntia ficus-indica. (F) Bougainvillea glabra. (G) Silene dioica. (H) Portulaca oleracea. Tomado y modificado de http://www.hondae.com/A03_Classification/APG-01-Tree.htm. 
Las razones evolutivas para la aparente eliminación de uno u otro pigmento, según sea el caso, no ha sido explicada adecuadamente; no obstante, a nivel bioquímico, se ha demostrado que las enzimas relevantes para la producción de antocianinas no se expresan en las plantas productoras de betalaínas (Brockington et al., 2011; Shimada et al., 2007).

Recientemente se descubrió el factor de transcripción MYB de antocianinas en la remolacha de Beta vulgaris (BvMYB1), el cual regula positivamente los genes de los mapas del locus Y, y de las enzimas clave de la ruta biosintética de betalaínas: BvDODA1 y BvCYP76AD1 (Figura 2A y B). La sobre expresión de BvMYB1 en raíces transformadas de remolacha blanca, dio lugar a la aparición de raíces fibrosas rojas, similares a las raíces fibrosas de la remolacha roja (Figura 2C y D). Los análisis filogenéticos indican que BvMYB1 de remolacha y MYBs de las plantas que producen antocianinas probablemente derivan de un ancestro común, consistente con la hipótesis de que los genes implicados en la biosíntesis de antocianinas y betalaínas están regulados por el mismo tipo de factores de transcripción. Al parecer BvMYB1 evolucionó de MYBs de antocianina, con nuevas características. Esto podría ser un caso de cooptación génica: uso de un gen existente para un nuevo propósito. Es decir, parece que el factor de transcripción MYB existente adquirió de alguna manera nuevas dianas transcripcionales, lo que le permite regular genes de las enzimas implicadas en la ruta de betalaínas (Figura 2A). La cooptación de MYB de antocianina podría haber dado lugar a nuevos pigmentos con el mismo patrón de expresión. Lo anterior ha sido confirmado con el estudio filogenético sobre la reconstrucción ancestral de la aparición de betalaínas, el cual revelo que la duplicación del gen de DODA y 
CYP76AD1, dio lugar a las isoformas DODA- $\alpha$ y CYP761A- $\alpha$ con la función específica de síntesis de betalaínas; las subsiguientes duplicaciones de estos genes dieron lugar a la pérdida o a la baja regulación de los genes que codifican para las enzimas específicas de la ruta de antocianinas (Brockington et al., 2015). De esta forma podría explicarse la pérdida de una de las dos vías y por tanto el hecho de que las antocianinas y betalaínas se excluyan de manera mutua, ya que aparentemente ambos pigmentos proporcionan en gran parte la misma función dentro de la planta. Sin embargo, se observa que las betalaínas pueden ser amarillas o violetas y las antocianinas suelen ser sólo moradas, por lo que el espectro de colores y por lo tanto la función no es estrictamente idéntico; por lo que probablemente BvMYB1 se ha apartado de las MYBs de antocianina, perdiendo la capacidad de regular las antocianinas o interactuar con el complejo de MBW (Hatlestad et al., 2015).
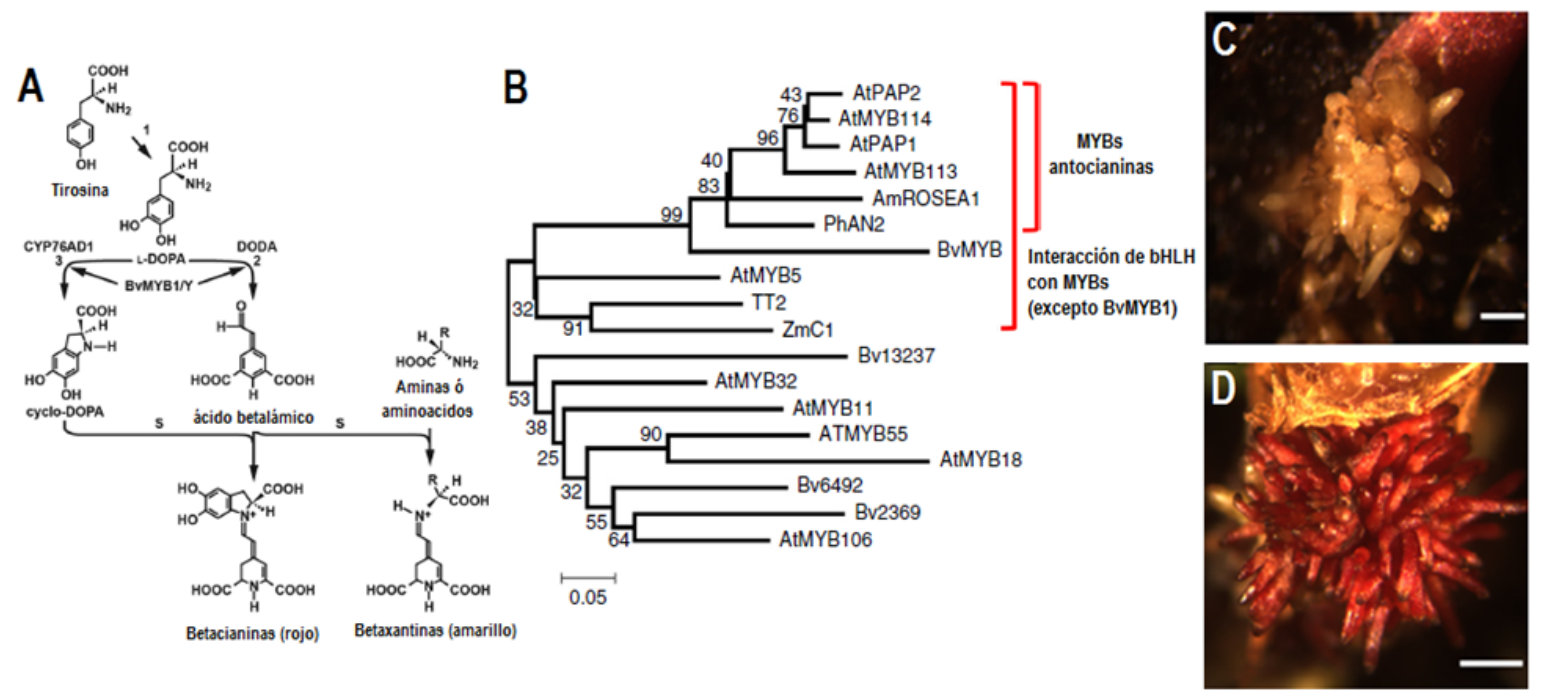

Figura 2. Regulación positiva del gen BvMYB1 en Beta vulgaris. (A) La sobreexpresión de BvMYB1 sobre la ruta de biosíntesis de betalaínas, controla la expresión de genes de enzimas clave como BvDODA y BvCYP76AD1. Los pasos 1, 2 y 3 son mediados enzimáticamente. Los pasos marcados con S son espontáneos. (B) Empalme en el árbol filogenético de los dominios R2 y R3 de BvMYB1 y otros MYBs. (C) Raíces transformadas de remolacha blanca. (D) Raíces transformadas de remolacha blanca pigmentadas de rojo (betanina) debido a la presencia de la sobreexpresión del gen BvMYB1. Tomado y modificado de Hatlestad et al., 2015. 


\section{Características generales de las betalaínas}

\section{Estructura química}

Las betalaínas son pigmentos solubles en agua, que contienen nitrógeno y presentan un peso molecular entre 400 y $500 \mathrm{~g} / \mathrm{mol}$ (Piattelli 1981). La unidad funcional y estructural de las betalaínas es el ácido betalámico (Figura 3A). Existen dos tipos de betalaínas: Las betaxantinas (Figura 3B), son derivados imonio producidos por la condensación del ácido betalámico con diferentes aminas y aminoácidos (Tabla 1), y las betacianinas (Figura 3C), que resultan de la condensación del ácido betalámico con ciclo-dihidroxifenilalanina (Ciclo-DOPA). Las betaxantinas son de color amarillo, su espectro de absorbancia tiene una longitud de onda máxima $\left(\lambda_{\mathrm{m}}\right)$ de aproximadamente $480 \mathrm{~nm}$, independiente de la naturaleza del aminoácido. Por el contrario, las betacianinas de color violeta, presentan un espectro de absorbancia centrado en $\lambda_{\mathrm{m}}=536 \mathrm{~nm}$ (Gandía-Herrero y García-Carmona, 2013). El color de las betalaínas se atribuye a sus estructuras en resonancia (Figura 4): si R o $\mathrm{R}^{\prime}$ no proyectan la resonancia, el compuesto es amarillo: betaxantinas; si $\mathrm{R}$ o $\mathrm{R}^{\prime}$ proyectan resonancia, el compuesto es violeta: betacianinas (Fennema, 1995).

El nombre trivial de las betalaínas fue asignado atendiendo a la fuente de donde fue descrito, derivándolo del nombre de la planta y añadiendo el sufijo “-cianina” (gr. kyanos, color azul) para las betacianinas, o “-xantina” (gr. xanthos, color amarillo) para las betaxantinas (García-Carmona et al., 2011). 
<smiles>O=CC=C1C=C(C(=O)O)N[C@H](C(=O)O)C1</smiles>

A<smiles>[R1]C(N=C/C=C1/C=C(C(=O)O)N[C@H](C(=O)O)C1)C(=O)O</smiles>

B

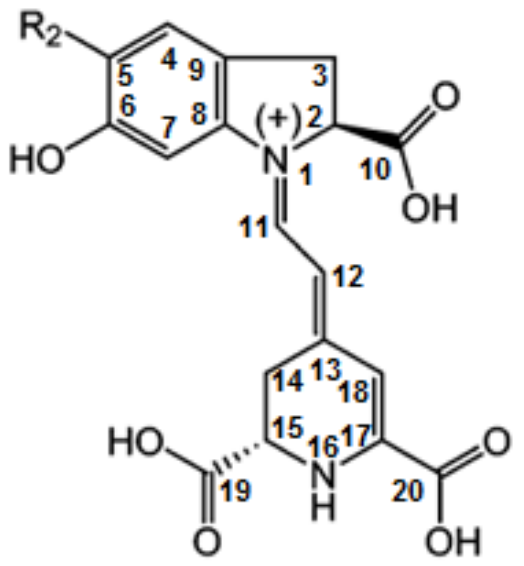

C

Figura 3. Estructuras generales del ácido betalámico (A), betaxantinas (B) y betacianinas $(C)$. $R_{1}$ es cualquier residuo lateral presente en aminas o aminoácidos. $\mathrm{R}_{2}$ es -OH (betanidina), glucosa (betanina), o un residuo o complejo de azúcar. Tomado de Gandía-Herrero et al., 2012.<smiles>[R]C(C=CN([R])[R])=C[NH+]=[NH+]</smiles>

Figura 4. Estructura de resonancia de las betalaínas. Tomado de Fennema, 1995.

Las betacianinas tienen como principal componente a la betanina (Figura 5Aa). Las betacianinas incorporan fundamentalmente azúcares a su estructura (Strack et al., 2003). La incorporación de azúcares y ácidos se produce a través de uno de los dos grupos hidroxilo presentes en el anillo aromático de la betanidina y origina dos familias de compuestos, derivados de betanina (betanidina 5-O- $\beta$-glucósido) o los de gomfrenina (betanidina 6-O- $\beta$ glucósido) (Gandía-Herrero et al., 2005a). 
Tabla 1. Betaxantinas identificadas estructuralmente en las plantas

\begin{tabular}{|c|c|c|c|}
\hline Nombre Trivial & Grupo amino & Fuente biológica & Referencia \\
\hline Indicaxantina & Prolina & Opuntia ficus-indica & Piatelli et al., 1964 \\
\hline Vulgaxantina I & Glutamina & Beta vulgaris & Piatelli et al., 1965 \\
\hline Vulgaxantina II & Ácido glutámico & Beta vulgaris & Piatelli et al., 1965 \\
\hline Miraxantina I & Metionina sulfóxido & Mirabilis jalapa & Piatelli et al., 1965 \\
\hline Miraxantina II & Ácido aspártico & Mirabilis jalapa & Piatelli et al., 1965 \\
\hline Miraxantina III & Tiramina & Mirabilis jalapa & Piatelli et al., 1965 \\
\hline Miraxantina V & Dopamina & Mirabilis jalapa & Piatelli et al., 1965 \\
\hline Portulacaxantina $\mathrm{I}^{\mathrm{a}}$ & Hidroxiprolina & Portulaca grandiflora & Piatelli et al., 1965 \\
\hline Dopaxantina & Dihidroxifenilalanina & Glottiphylum longum & Impellizzeri et al., 1973 \\
\hline Humilixantina & 5-Hidroxinorvalina & Rivina humilis & Strack et al., 1987 \\
\hline Portulacaxantina II & Tirosina & Portulaca grandiflora & Trezzini y Zryd., 1991 \\
\hline Portulacaxantina III & Glicina & Portulaca grandiflora & Trezzini y Zryd., 1991 \\
\hline Vulgaxantina III & Asparagina & Beta vulgaris & Hempel y Bohom, 1997 \\
\hline Vulgaxantina IV & Leucina & Beta vulgaris & Hempel y Bohom, 1997 \\
\hline \multirow[t]{17}{*}{ Muscaaurina VII $^{\text {b }}$} & Histidina & Beta vulgaris & Hempel y Bohom, 1997 \\
\hline & Triptófano & Celosia argentea & Schliemann et al., 2001 \\
\hline & 3-Metoxitiramina & Celosia argentea & Schliemann et al., 2001 \\
\hline & Ácido $\Upsilon$-aminobutírico & B. vulgaris, $O$. ficus-indica & Stintzing et al., 2002 \\
\hline & Serina & B. vulgaris, O. ficus-indica & Stintzing et al., 2002 \\
\hline & Valina & B. vulgaris, O. ficus-indica & Stintzing et al., 2002 \\
\hline & Isoleucina & B. vulgaris, O. ficus-indica & Stintzing et al., 2002 \\
\hline & Fenilalanina & B. vulgaris, O. ficus-indica & Stintzing et al., 2002 \\
\hline & Alanina & Beta vulgaris & Kugler et al., 2004 \\
\hline & Histamina & Beta vulgaris & Kugler et al., 2004 \\
\hline & Metionina & Opuntia ficus-indica & Stintzing et al., 2005 \\
\hline & Arginina & Gomphrena globosa & Kugler et al., 2007 \\
\hline & Putrescina & Bougainvillea sp. & Kugler et al., 2007 \\
\hline & Lisina & Bougainvillea sp. & Kugler et al., 2007 \\
\hline & Etanolamina & Beta vulgaris & Kugler et al., 2007 \\
\hline & Treonina & Beta vulgaris & Kugler et al., 2007 \\
\hline & Feniletilamina & Opuntia ficus-indica & Castellanos-Santiago y Yahia, 2008 \\
\hline
\end{tabular}

a Pigmento originalmente llamado "portulacaxantina”.

${ }^{\mathrm{b}}$ Pigmento previamente identificado en el hongo Amanita muscaria (Musso, 1979)

Tabla tomada y modificada de Gandía-Herrero y García-Carmona, 2013.

\section{A. Isómeros estructurales}

Las betacianinas se pueden hidrolizar con ácidos o enzimas y formar las agliconas llamadas betacianidinas y el azúcar respectivo. Las agliconas de las betacianinas son 
diasteroisómeros y se les dieron los nombres de betanina e isobetanina, betanidina e isobetanidina en el betabel y amarantina e isoamarantina en el amaranto (Figura 5). La presencia conjunta de diasteroisómeros en extractos de plantas conteniendo betacianinas es bien conocida (Piatelli, 1981; Stintzing y Carlie, 2004). Esta isomería es debida a la presencia del átomo de carbono quiral en la posición C-15 (Figura 3), que puede adoptar las configuraciones “ $S$ ” o “ $R$ ”. El átomo quiral en posición $C-2$ adopta en la naturaleza únicamente la configuración “S”. De este modo, para las betacianinas existentes los compuestos 2-S/15-S y 2-S/15-R, abreviadamente $2 S / S$ y $2 S / R$. De ellos, el isómero $2 S / S$ es el mayoritario y primario, postulándose que el $2 S / R$ se obtiene por epimeración. La conversión de compuestos $2 S / S$ en $2 S / R$ ha sido descrita en función del pH (Schliemann y Strack, 1998). Por otro lado, de manera sintética pueden obtenerse los isómeros no naturales $2 R / S$ y $2 R / R$ de las betacianinas (Wilcox et al., 1965) y análogamente de las betaxantinas (Schliemann et al., 1999). Formas “ $R$ ” de áminoacidos libres suministrados a plantas fueron incorporadas como betaxantinas (Hempel y Böhm, 1997), llevando a consideraciones acerca de una posible condensación espontánea entre el ácido betalámico y los aminoácidos y/o la falta de estereoespecificidad de las enzimas implicadas (GandíaHerrero et al., 2005a).

\section{Propiedades ópticas}

Los pigmentos son moléculas que por su estructura química absorben luz de una determinada longitud de onda y reflejan el resto, emisión que define el color que percibe el ojo humano. La parte de la molécula responsable del color (cromóforo), suele contener una 
cadena de dobles enlaces conjugados, estos dobles enlaces generan un sistema de resonancia con los estados electrónicos, cuya separación energética coincide con la energía de ciertos fotones del rango visible de la luz; esos son los fotones que absorbe el pigmento. En algunos pigmentos la exposición a la luz provoca además la emisión de nuevos fotones, generando así la fluorescencia (Figura 6A) (García-Carmona et al., 2011).

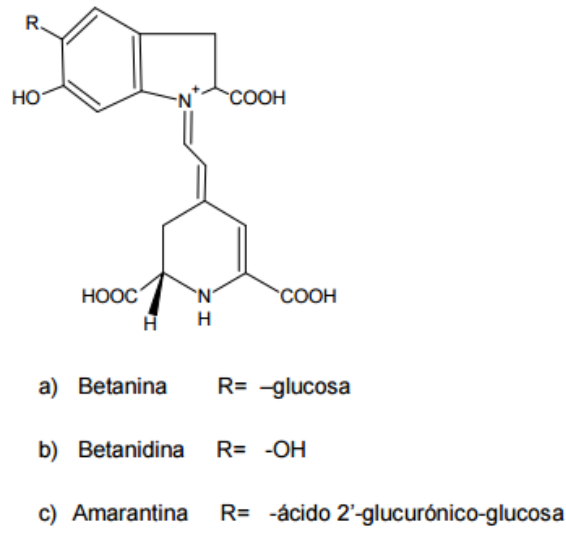

A. Betacianinas

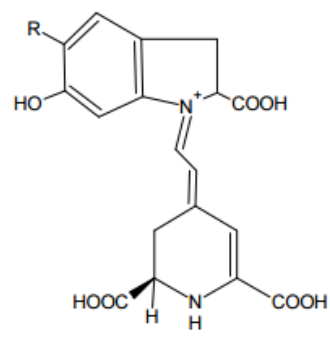

$\begin{array}{ll}\text { d) Isobetanina } & R=\text {-glucosa } \\ \text { e) Isobetanidina } & R=-O H \\ \text { f) Isoamarantina } & R=\text {-ácido 2'glucurónico-glucosa }\end{array}$

B. Isómeros de Betacianinas

Figura 5. Estructura de los diateroisómeros de betacianinas. Tomado de Fennema, 1995.
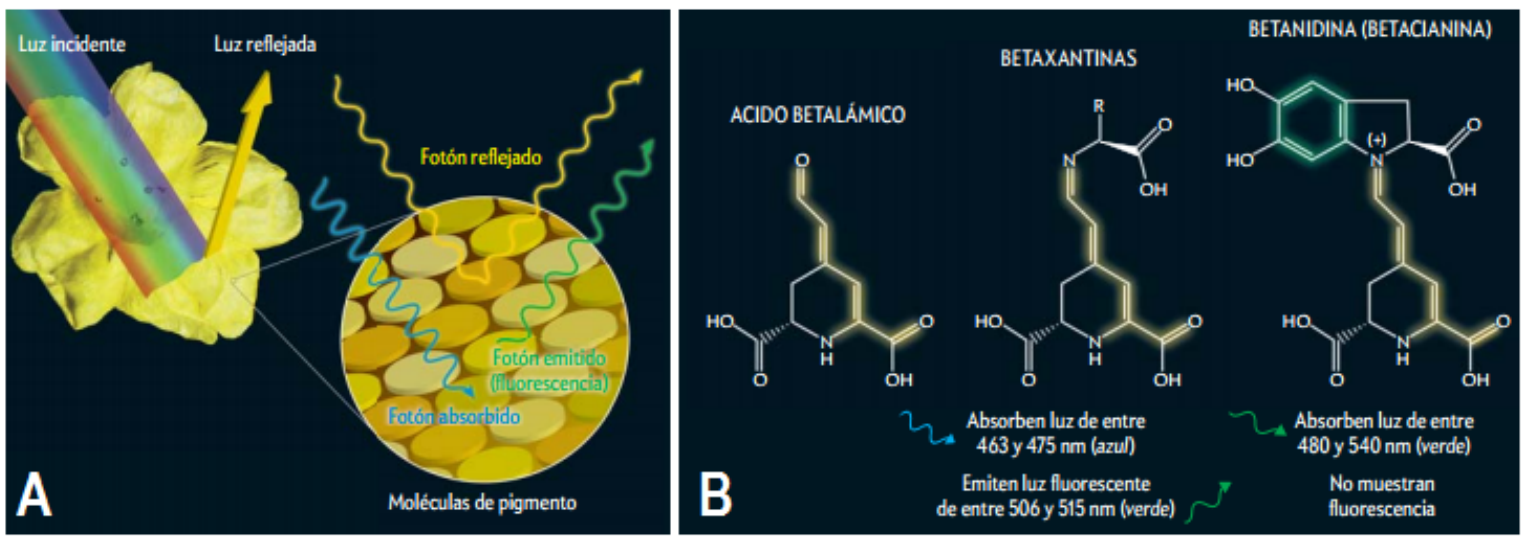

Figura 6. Propiedades ópticas de las betalaínas. (A) Fenómeno de absorción y emisión de fotones. (B) Patrón de fluorescencia con máximos de excitación y de emisión. Tomado y modificado de García-Carmona et al., 2011. 
Desde los primeros trabajos en betalaínas se caracterizaron los espectros de absorción en betacianinas (Wyler y Dreiding, 1957) y betaxantinas (Piattelli et al., 1964). El espectro de betanina presenta un máximo a 536 nm (Trezzini y Zrÿd, 1991), que se desplaza hipsocrómicamente con la descarboxilación del grupo del carbono C-2 (Kobayashi et al., 2001). El mayor desplazamiento en el mismo sentido se produce en el compuesto 14-15 dehidrobetanina (neobetanina) de color naranja y no violeta (Alard et al., 1985). Por otra parte un desplazamiento batocrómico se observa al esterificar betacianinas con ácidos hidroxicinámicos (Stintzing y Carlie, 2004). En las betaxantinas puede observarse el mismo desplazamiento hipsocrómico con la descarboxilación de C-2 de tirosina betaxantina y de dopaxantina. El pigmento derivado de prolina presenta el máximo de mayor longitud de onda (484 nm), el cual presenta un coeficiente de absorción molar menor (Trezzini y Zryd, 1991).

Actualmente se sabe que las betaxantinas presentan un patrón de fluorescencia con máximos de excitación comprendidos entre 463 y 475 nm y máximos de emisión entre 506 y 515 nm (Figura 6B). De modo que las betaxantinas absorben luz en el rango visible del espectro electromagnético correspondiente al color azul y emiten luz verde. Los espectros de excitación y emisión son muy similares en todos los casos y análogos al descrito para la betaxantina más sencilla, la alanina betaxantina. La separación entre la longitud de onda máxima de excitación y la máxima de emisión (desplazamiento de Stokes), así como la anchura de los espectros, (mediada a un valor de intensidad mitad del máximo) son también semejantes. Tantas semejanzas apuntan a la estructura de las betaxantinas y el ácido 
betalámico, está implicado en el fenómeno de fluorescencia. Esta estructura básica es además la responsable del color de los pigmentos, debido a su sistema de dobles enlaces conjugados. La intensidad de la fluorescencia depende del carácter “dador” o “aceptor” electrónico del sustituyente (R) del grupo amina o aminoácido que se encuentre unido al ácido betalámico. Cuanto mayor sea su carácter aceptor y, cuanta más densidad electrónica “absorba” del sistema resonante, más intensa será la fluorescencia de la betaxantina. Las betacianinas en cambio no presentan fluorescencia. Ello se debe a la conexión que se produce entre los dos sistemas resonantes: el ácido betalámico (amarillo) (Figura 6B) y el del anillo aromático del ciclo DOPA (verde); esta ampliación del sistema resonante es la responsable del desplazamiento del máximo del espectro de absorbancia de 480 a 540 nm, así mismo es el responsable de la ausencia de fluorescencia en los pigmentos violetas (Figura 6B) (Gandía-Herrero et al., 2010). También se observa un solapamiento entre el espectro de emisión de las betaxantinas y el de absorción de las betacianinas. Este fenómeno puede provocar en un sistema que contenga un fluróforo (estructura responsable de la fluorescencia) y un cromóforo (estructura responsable del color), la atenuación de fluorescencia, si el cromóforo es capaz de absorber la radiación emitida por el compuesto fluorescente. Lo anterior se le conoce como “efecto de filtro interno” (Figura 7). La adición progresiva de una betacianina a una disolución de betaxantina, provoca la extinción, por este efecto, de la fluorescencia. Ello demuestra que las betacianinas absorben la radiación emitida por las betaxantinas (García-Carmona et al., 2011). Para apreciar la fluorescencia específica de las betaxantinas se utiliza un sistema de filtros, uno limita las longitudes de onda para la excitación de los pigmentos de la muestra, otro filtra la luz residual reflejada 
por la misma. De esta manera se ha demostrado que la emisión de luz visible por parte de las betaxantinas se mantiene en su entorno fisiológico y que las flores que las contienen pueden considerarse como elementos fluorescentes; tal es el caso de Mirabilis jalapa especie que puede presentar flores con patrones de colores variados dentro de la misma planta. En este caso pueden existir zonas que contienen sólo betaxantinas y otras que contienen sólo betacianinas. Al filtrar la radiación de excitación y la luz emitida, se observa que el efecto de filtro interno descrito en disolución se mantiene en el entorno fisiológico: las flores presentan patrones fluorescentes de contraste (Figura 7B). La interferencia de la fluorescencia también puede apreciarse a través de microscopía de fluorescencia (Figura 7B) (Gandía-Herrero et al., 2005a).
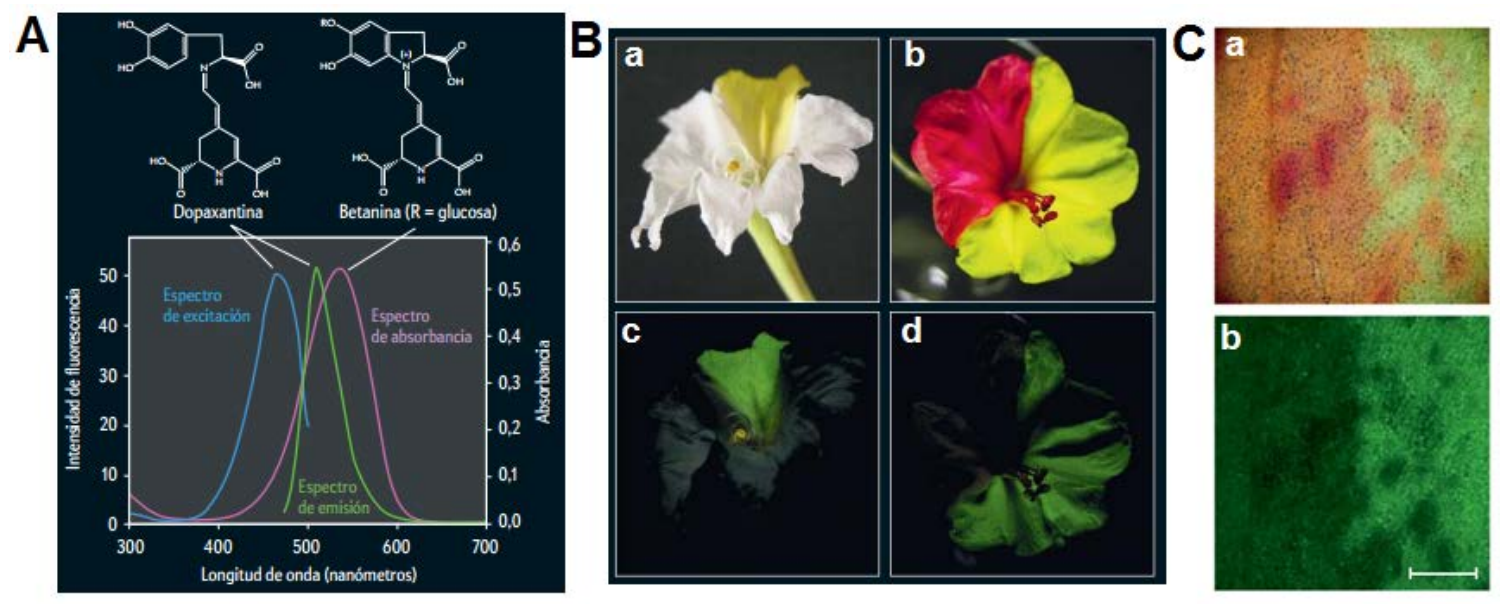

Figura 7. Efecto de filtro interno y patrones de contraste de fluorescencia. (A) Solapamiento entre el espectro de emisión de las betaxantinas (verde) y el de absorción de las betacianinas (violeta). (B) Fluorescencia en flores de Mirabilis jalapa, cuando se ilumina con luz blanca (a y b) las áreas de las flores que contienen sólo betaxantinas parecen amarillas debido a la combinación de fluorescencia y la radiación no absorbida, o reflejada. Cuando se ilumina con luz azul (c y d) las betaxantinas emiten fluorescencia verde. (C) Imágenes microscópicas de campo claro (a) y epifluorescencia (b) de una sección de un pétalo rojo y amarillo de Mirabilis jalapa. La fluorescencia verde se debe a las betaxantinas; en las áreas obscuras (naranjas en a), la luz emitida por el pigmento fluorescente es absorbida por la betanina. Tomado y modificado de García-Carmona et al., 2011. 


\section{Actividad biológica}

Las primeras investigaciones que evidenciaron la actividad atrapadora de radicales libres en betalaínas, fueron llevadas a cabo por separado con betacianinas y betaxantinas, extraídas de raíz de remolacha (Escribano et al., 1998). En 2002 y 2003, se realizó la caracterización de betalaínas de diferentes extractos de plantas y frutos, elucidándose la importancia de los grupos hidroxilo en la estructura para la existencia de actividad antioxidante (Butera et al., 2002; Pavlov et al., 2002; Cai et al., 2003). Subsiguientes trabajos del grupo de investigación de Kanner demostró la capacidad de betanina y betanidina de inhibir la peroxidación in vitro del ácido linoleico, la oxidación de las lipoproteínas de baja densidad (LDL) y la hemolisis de glóbulos rojos a concentraciones más bajas que otros antioxidantes conocidos como el $\alpha$-tocoferol y la catequina. Así mismo, las betalaínas presentan potencial quimiopreventivo contra diferentes tipos de cáncer (Wu et al., 2006; Sreekanth et al., 2007; Khan et al., 2012). Se ha reportado que estos pigmentos inhiben in vivo la formación de tumores en ratones, consumiendo bajas concentraciones de betalaínas en la dieta (Kapadia et al., 2003; Lu et al., 2009; Lechner et al., 2010). También ejercen influencia antioxidante y estabilizadora sobre el ácido hipocloroso, el cual está implicado en la respuesta inflamatoria (Allegra et al., 2005). Así mismo, las betacianinas tienen efecto neuroprotector, ya que mejoran las deficiencias cognitivas y atenúan el daño oxidativo inducido por D-galactosa en el cerebro de ratones senescentes (Wang y Yang, 2010). 
En 2012 y 2014 la actividad anti-inflamatoria demostrada en los extractos de inflorescencias de Gomphrena y frutos de Opuntia actividad anti-inflamatoria, ha sido atribuida a la presencia de betalaínas (Silva et al., 2012; Dulce et al., 2014). Recientemente se demostró que las betalaínas semi-sintéticas y betalaínas purificadas de extractos vegetales de raíces de Beta vulgaris y de flores amarillas y violetas de Lampranthus productos, inhiben la actividad de enzimas (lipooxigenasas y ciclooxigenasas) implicadas en la respuesta bioquímica a la inflamación (Vidal et al., 2014).

La relación estructura-actividad de las betalaínas ha sido atribuida a la presencia del ácido betalámico en su estructura, aunque también puede ser modulada por otros factores estructurales (Gandía-Herrero et al., 2012). La presencia de ciclos aromáticos en resonancia con el sistema principal de resonancia de electrones, para formar una subestructura tipo indolina, como la presente en betacianinas, implica una mejora en la actividad antirradical y antiinflamatoria (Gandía-Herrero et al., 2010: Vidal et al., 2014). La presencia de grupos hidroxilo en la molécula aumenta la capacidad antioxidante y antirradical, en betaxantinas y en betacianinas. Se ha detectado un aumento en términos de unidades de Trolox (capacidad antioxidante equivalente de Trolox, TEAC), a 4.0 unidades TEAC para un hidroxilo y a 6.34 unidades TEAC para dos hidroxilos (Gandía-Herrero et al., 2010). El último valor es mayor que el encontrado para otros antioxidantes conocidos tales como galato de epigalocatequina (EGCG) presente en el té verde (Rice-Evans et al., 1996; Stewart et al., 2005). 


\section{Biosíntesis de las betalaínas}

En la biosíntesis de metabolitos secundarios, como son las betalaínas, ocurren una serie de procesos biológicos y fisicoquímicos muy complejos, que tienen que ver con aspectos bioquímicos, fisiológicos y de fenómenos de transporte que dan como resultado diferentes niveles de diferenciación celular, la compartamentalización, translocación, almacenamiento e incluso procesos de redireccionamiento del flujo metabólico (Zhang et al., 2002; Strack et al., 2003). De manera general en las células de los vegetales, frecuentemente los precursores de metabolitos secundarios, se encuentran en el citoplasma y son trasladados hacia algún organelo para que se lleve a cabo la síntesis del metabolito (Zhang et al., 2002). Parece ser que éste es el caso de las betalaínas.

La Figura 8 muestra de manera esquemática el mecanismo propuesto de síntesis y acumulación de betalaínas. Se ha sugerido que la biosíntesis de betaxantinas involucra el transporte del ácido betalámico del citosol hacia el interior de la vacuola, en donde bajo condiciones ácidas se condensa con diferentes aminoácidos y aminas (Schliemann et al., 1999; Stintzing et al., 1999). La síntesis de betanidina se realiza en el citoplasma, donde el pH es de 7 a 7.5. Por su naturaleza altamente hidrofílica, es transportada a la vacuola (pH 3 a 6), donde se ioniza de manera parcial, lo que impide que pueda difundir hacia el exterior, permitiendo por lo tanto su acumulación y almacenamiento. Al ser una molécula protonada, la betanidina puede interactuar con otras moléculas contenidas en la vacuola, como por 
ejemplo la glucosa y a través de reacciones de glucosilación, formar otras betacianinas como la betanina (Stintzing et al., 1999; Strack et al., 2003).

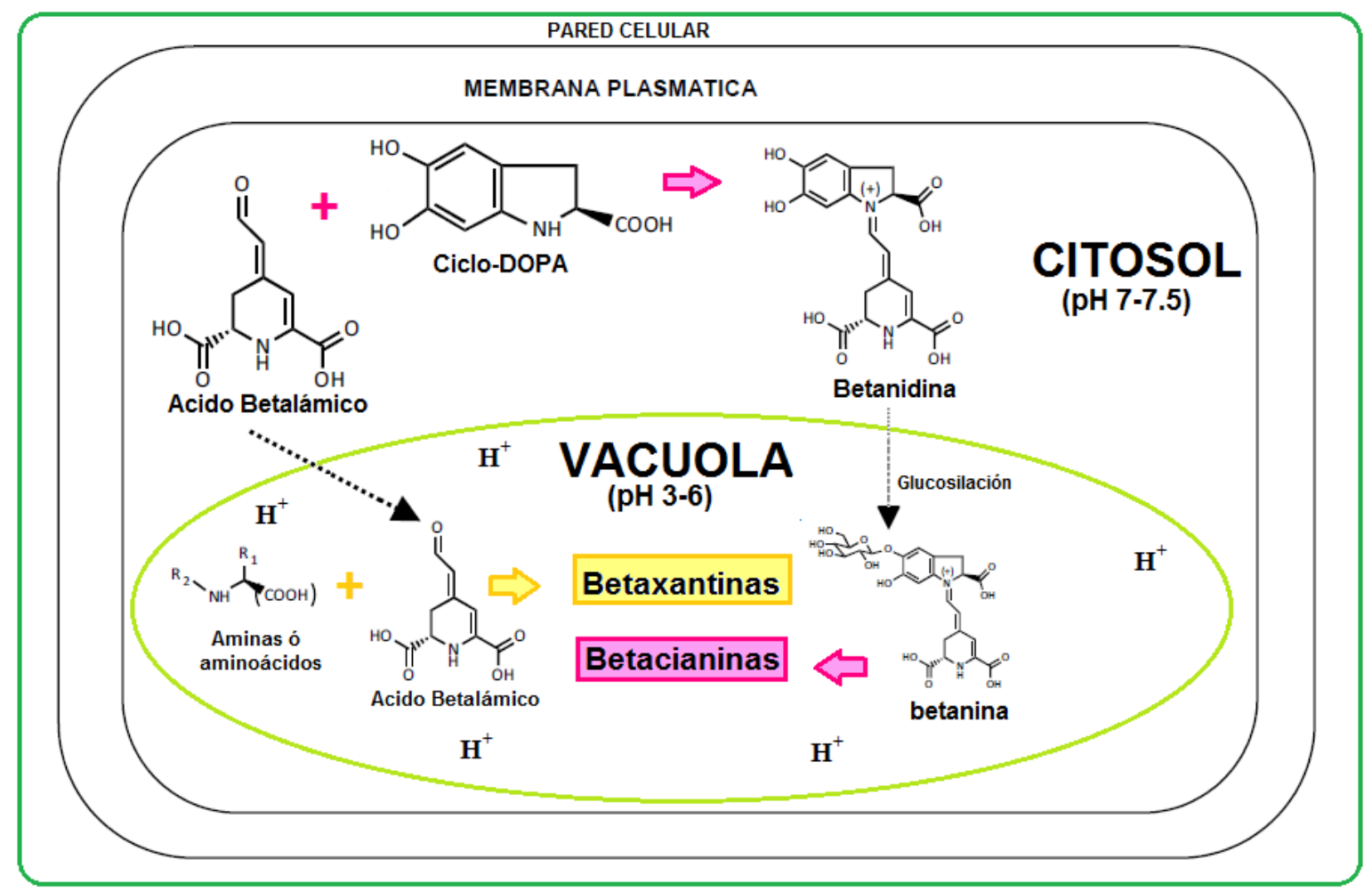

Figura 8. Mecanismo propuesto para la síntesis y almacenamiento de betalaínas en el interior de la célula. Adaptado de Schliemann et al., 1999; Stintzing et al., 1999 y Strack et al., 2003.

\section{Enzimas clave}

La ruta biosintética de betalaínas incluye tres principales enzimas. Dos son oxidasas que dependen de oxígeno molecular para la catálisis: la tirosinasa y 4,5-DOPA-extradioldioxigenasa (DODA). La segunda enzima la betanidin-glicosiltransferasa adiciona a la unidad estructural de betacianinas un residuo de azúcar (Gandía Herrero y García Carmona, 2013). 
La DODA cataliza la transformación de L-DOPA a 4,5-seco-DOPA (Figura 9, reacción de 2), que produce espontáneamente ácido betalámico, la unidad estructural y cromóforo de las betalaínas (Gandía-Herrero y García Carmona, 2013).

La actividad de la enzima tirosinasa se ha descrito en cinco pasos diferentes de la ruta biosintética de betalaínas (Figura 9, reacciones 1, 5, 14,15, y 23). Esta enzima esta ampliamente distribuida en la naturaleza y su mecanismo de acción es bien conocido, cataliza la hidroxilación de monofenoles a o-difenoles y la oxidación de los o-difenoles a oquinonas (Gandía-Herrero y García Carmona, 2013).

Las glicosiltransferasas catalizan la transferencia de moléculas de azúcar a aceptores específicos como compuestos tóxicos ambientales, hormonas y metabolitos secundarios, incluyendo pigmentos. La adición de glucosa a betanidina es dirigida específicamente a uno de los dos grupos hidroxilo paragenerar betanina (Figura 9, reacción 19) o gomfrenina I. A pesar de las analogías estructurales con betacianinas, no hay evidencia in vivo o in vitro para la glicosilación en betaxantinas (Gandía-Herrero y García Carmona, 2013).

\section{Formación de ácido betalámico}

Las betalaínas se derivan del aminoácido L-tirosina. En las plantas dicho compuesto procede del ácido arogénico (Tzin y Galili, 2010). Experimentos pioneros con moléculas de L-tirosina marcadas radiactivamente demostraron su incorporación en las unidades estructurales de las betalaínas (Liebisch et al. 1969; Fischer y Dreiding, 1972). 
La biosíntesis de las betalaínas comienza con la hidroxilación de L-tirosina en L-DOPA a través de la actividad de la enzima tirosinasa monofenolasa (o polifenoloxidasa) (Figura 9, reacción 1). La tirosinasa se ha caracterizado en las plantas Portulaca grandiflora, Beta vulgaris, y Suaeda salsa (Steiner et al., 1999; Gandía-Herrero et al., 2004; Gao et al., 2009). La enzima también se ha purificado a partir del hongo Amanita muscaria (Mueller et al., 1996). La acumulación de L-DOPA, que es necesaria para la formación de ácido betalámico (Figura 9, reacción 2), requiere detener la oxidación de L-DOPA a o-DOPAquinona (Figura 9, reacción 5) realizada por la actividad difenolasa de la misma enzima. Esta reacción puede ser necesaria para la formación de una parte de la estructura de betacianinas, como se discute a continuación, pero consumirá toda la L-DOPA formada como sustrato (Cabanes et al., 1987). Por lo tanto, la presencia de ácido ascórbico o un agente de reducción análogo es necesario para transformar o-DOPA-quinona de nuevo a LDOPA (Figura 9, reacción 6). Esto hace L-DOPA disponible nuevamente como sustrato para la segunda enzima de la ruta, la DODA, que cataliza la escisión extradiol de L-DOPA para formar el producto intermedio 4,5-seco-DOPA (Figura 9, reacción 2). La proteína se caracterizó primero a partir de extractos A. muscaria (Girod y Zryd, 1991), dicha enzima produce ácido betalámico y muscaflavina, que se encuentra exclusivamente en el hongo. Esto es debido a la actividad 2,3-DOPA-extradiol dioxigenasa que produce 2,3-secoDOPA, producto análogo de 4,5-seco-DOPA en plantas (Mueller et al,. 1997). DODA en P. grandiflora, Mirabilis jalapa, y B. vulgaris se ha caracterizado funcionalmente $\mathrm{y}$ muestra la actividad de 4,5-DOPA-extradiol-dioxigenasa exclusivamente (Christinet et al., 2004; Sasaki et al., 2009; Gandía-Herrero y García-Carmona, 2013). 
El ácido betalámico se deriva a partir de 4,5-seco-DOPA, por la condensación intramolecular espontánea entre el grupo amina presente en L-DOPA y el grupo aldehído producido enzimáticamente (Fischer y Dreiding, 1972) (Figura 9, reacción 3). Las características estructurales del ácido betalámico no se entienden bien en términos de la configuración del carbono quiral. En las plantas, los pigmentos derivados del betalámico se reportan con frecuencia para mostrar el 95\% del isómero quiral (S) y 5\% de la forma (R). Además, las mismas proporciones se han reproducido in vitro a partir de L-DOPA en ensayos enzimáticos con la dioxigenasa (Sasaki et al., 2009; Gandía-Herrero y GarcíaCarmona, 2013). Este hallazgo señala a las reacciones 2 y 3 (Figura 9) como las responsables para las proporciones de isómeros que se encuentran en la naturaleza (GandíaHerrero y García-Carmona, 2013).

\section{Formación de betalaínas}

La variedad de betalaínas surge de incorporar múltiples derivados amino a una unidad de ácido betalámico como estructura cromogénica en el sistema de resonancia de electrones. Dependiendo de la naturaleza de la molécula condensada, se obtienen diferentes propiedades espectroscópicas (Gandía-Herrero et al., 2010).

En las plantas, las betaxantinas (pigmentos amarillos) se obtienen por condensación del ácido betalámico con aminas y aminoácidos (Figura 9, reacción de 4). Se asume que la reacción se produce de forma espontánea entre el grupo amino de la amina y el grupo aldehído del ácido betalámico para formar la imina correspondiente (Schliemann et al., 
1999; Godoy-Alcántar et al., 2005). Esta reacción se puede reproducir in vitro para formar betaxantinas semisintéticas (Sekiguchi et al., 2010). La diversidad de aminas disponibles en las plantas hace que sea difícil estimar el número real de betaxantinas existentes en la naturaleza (Tabla 1) (Gandía-Herrero y García Carmona, 2013).

La formación de betacianinas puede darse a través de la condensación con los derivados libres de L-DOPA; que en ausencia de un agente reductor se transforma por la tirosinasa en o-DOPA-quinona utilizando oxígeno molecular (Figura 9, reacción 5). Luego, el grupo amina de la o-quinona realiza un ataque nucleofílico intramolecular en el anillo, lo que conduce a la ciclación espontánea que forma la molécula de leuco-DOPA-cromo, también conocido como ciclo-DOPA (Wyler y Chiovini 1968; Li y Christensen, 1993; Cabanes et al., 2002) (Figura 9, reacción 7). La conversión de L-DOPA en ciclo-DOPA se puede realizar por la citocromo P450, como se ha visto en B. vulgaris (Hatlestad et al., 2012). Aunque el mecanismo involucrado en la formación de ciclo-DOPA, no ha sido plenamente identificado, sólo dos posibilidades parecen razonables: una oxidación clásica o una transferencia electrónica por etapas (Guengerich, 2001). En ambos casos, DOPA-quinona sería un producto de oxidación intermedio antes del ataque nucleófilo intramolecular que se produce, de acuerdo con las reacciones descritas para la tirosinasa (Figura 9, reacciones 5 y 7). Sin embargo, debido a la falta de información sobre el mecanismo de oxidación de la DOPA por la subfamilia citocromo P450 (Hatlestad et al., 2012), esta reacción se muestra por separado en la Figura 9 (reacción 8). En cualquier caso, ciclo-DOPA presenta una estructura capaz de condensar con ácido betalámico y formar betanidina (Figura 9, reacción 
12). Las condiciones para la formación de betanidina a partir de dopaxantina-quinona (Figura 9, reacción 17) no se han determinado, pero la vía es posible y la formación de betanidina puede ser favorecido in vivo. Otra forma de condensación se lleva a cabo entre el ácido betalámico y L-DOPA para formar dopaxantina (Figura 9, reacción 18). También podría llevarse a cabo la condensación de ácido betalámico con o-DOPA-quinona; aunque el grupo amino está disponible para reaccionar con el grupo aldehído de ácido betalámico, la inestabilidad química de la DOPA-quinona podría evitar esta reacción (Gandía-Herrero y García-Carmona, 2013).

\section{Reacciones en betacianinas}

La betanidina se puede transformar en betanina por la enzima betanidin-5-Oglucosiltransferasa, que incorpora un residuo de glucosa al grupo hidroxilo en la posición 5 (Figura 9, reacción 19) (Hans et al., 2004). La betanidin-6-O-glucosiltransferasa también se ha purificado y caracterizado a partir de Dorotheanthus bellidiformis (Heuer et al., 1996), esta enzima cataliza la incorporación de glucosa para el otro grupo hidroxilo de betanidina, formando el pigmento gomfrenina I. Glucosilaciones y acilaciones adicionales conducen a la amplia variedad de betacianinas identificadas en extractos naturales (Strack et al., 2003). Sin embargo, las enzimas o las condiciones involucradas en estos procesos no han sido identificadas. Los pigmentos generados mantienen propiedades espectroscópicas análogas a los de betanidina, evitando su labilidad (Gandía-Herrero et al., 2007; Stintzing et al., 2002). La transformación de betanina a betanidina es posible debido a la actividad de $\beta$-glucosidasa (Figura 9, reacción 20) (Zakharova and Petrova, 2000). En contraste con la 
aceptación general de la glucosilación de betanidina, también se ha propuesto que la betanina puede formarse por la acción de una ciclo-DOPA $O$-5-glucosiltransferasa que cataliza la transferencia del azúcar a la ciclo-DOPA (Figura 9, reacción 21) y su posterior condensación del derivado glucósido con ácido el betalámico (Figura 9, reacción 22) (Sasaki et al., 2004). Esta actividad se ha encontrado en pruebas preliminares de $M$. jalapa y en otras plantas productoras de betalaínas (Sasaki et al., 2005a). Por la acilación adicional de ciclo-DOPA-glucósido es posible producir más complejos de betacianinas después de la condensación con el ácido betalámico (Sasaki et al., 2005b). Independientemente del papel desempeñado por la tirosinasa en la formación de betanidina, el pigmento es un sustrato para la enzima (Figura 9, reacción 23). Esto implica la formación de betanidina-quinona. La presencia de ácido ascórbico ha sido descrito en flores que contienen betanidina y revierte la quinona al pigmento original (Figura 9, reacción 24) (Gandía Herrero et al., 2007). Aunque la glucosilación protege a la betanina de la labilidad, el grupo hidroxilo restante de la betanidina todavía puede ser oxidado por la enzima peroxidasa (Figura 9, reacción 25). La betanina es transformada en el radical fenoxibetanina, el cual puede experimentar ulterior evolución que implica la hidrólisis de la molécula (Sasaki et al., 2005b). Los productos de oxidación de betanina son también capaces de reorganizarse y producir betacianinas deshidrogenadas y descarboxiladas (Wybraniec y Michałowski, 2011). La peroxidasa también puede actuar sobre la betanidina para catalizar su conversión a betanidina-quinona a través de un mecanismo de radicales. Dependiendo del $\mathrm{pH}$, este puede conducir a la generación de derivados de 
betanidina-quinona deshidrogenados y descarboxilados (Wybraniec y Michałowski, 2011; Martínez-Parra y Muñoz, 2001).

\section{Formación de betalaínas descarboxiladas}

Las betacianinas descarboxilas se han descrito en extractos de Carpobrotus acinaciformis (Piattelli y Impellizzeri, 1970) y Celosia sp. (Schliemann et al., 2001) y en cultivos de raíces transformadas de B. vulgaris (Schliemann et al., 1999; Kobayashi et al., 2001). Estas betacianinas contienen un fragmento de leuco-dopamina-cromo en lugar de leucoDOPA-cromo presente en su estructura. El punto exacto en la ruta para la descarboxilación es actualmente desconocido, sin embargo dos alternativas son posibles:

1) La formación de descarboxi-betacianinas pueden producirse a partir de betaxantinas de la misma manera como se ha mencionado para los pigmentos carboxilados a través de las reacciones mediadas por tirosina (Figura 9, reacciones14 y 15) (Gandía-Herrero et al., 2005a). Análogos descarboxilados de tirosina-betaxantina y DOPA-betaxantina son tiramina betaxantina (miraxanthin III) y la dopamina-betaxantina (miraxanthin V), respectivamente. Esta posibilidad es apoyada por la presencia de dopamina-betaxantina y las betacianinas descarboxiladas en B. vulgaris (Schliemann et al., 1999) y Celosia sp. (Schliemann et al., 2001).

2) La descarboxilación, también puede ocurrir en niveles libres de L-tirosina o L-DOPA, para formar tiramina o dopamina, respectivamente. Reacciones mediadas por la tirosinasa o 
bien reacciones espontáneas pueden conducir a la formación de dopamina cromo (Figura 9, reacciones 5 y 9), que podría ser transformada a leuco-dopamina-cromo (Figura 9, la reacción 11) por un agente reductor. La condensación con ácido betalámico entonces podría ocurrir para formar betacianinas descarboxiladas (Kobayashi et al., 2001). Alternativamente la peroxidasa también podría estar mediando a través de las reacciones mencionadas anteriormente (Wybraniec y Michałowski, 2011), en los estudios sobre la formación de betalainas descarboxiladas como artefactos durante la extracción del pigmento en plantas (Gandía-Herrero y García-Carmona, 2013).

\section{Betalaínas: colorantes naturales nutracéuticos}

El término nutracéutico fue acuñado en 1989 por el Dr. Stephen DeFelice, Presidente de la Fundación para la Innovación en Medicina, de los EE.UU. La palabra derivada de nutrición y farmacéutico, lo cual hace referencia a todos aquellos alimentos que poseen un efecto benéfico demostrado sobre la salud humana (Serra-Majem, 2008; Gil, 2010). Las betalaínas al presentar actividad antioxidante, antiiflamatoria, anticarcinogénica y neuroprotectora a bajas concentraciones, son consideradas sustancias nutracéuticas (Kapadia et al., 2003; Stintzing y Carle, 2004; Henriette y Azeredo, 2009); además al ser pigmentos naturales han sido utilizadas como fuente de colorantes (Fernández y Giménez, 2013). 


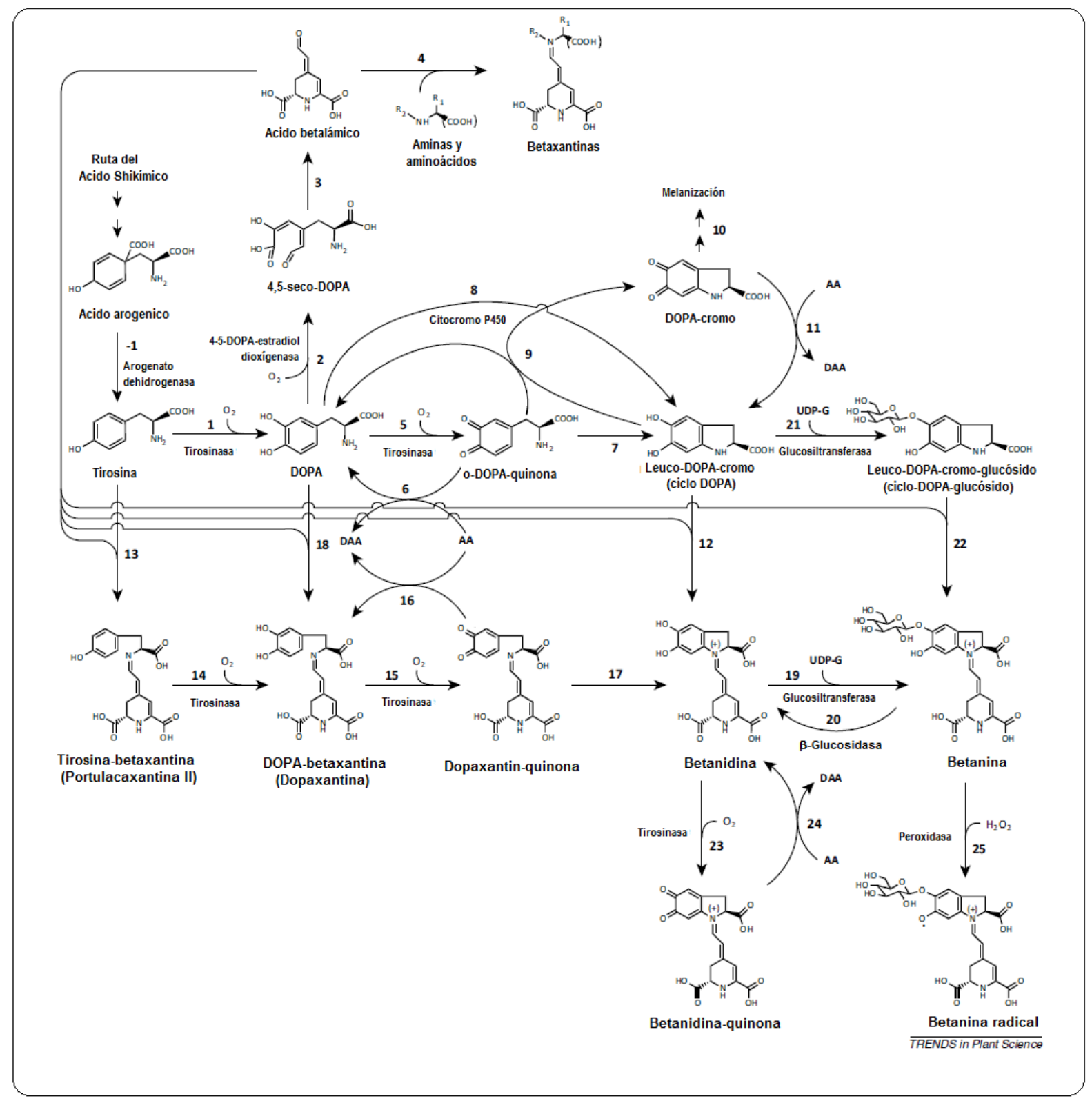

Figura 9. Esquema completo de la ruta de biosíntesis de betalaínas. Todas las reacciones reportadas en la bibliografía están representadas. Abreviaturas: AA, ácido ascórbico; DAA, ácido dehidroascórbico. Tomado y modificado de Gandía-Herrero y García-Carmona, 2013. 


\section{Colorantes}

Los colorantes alimentarios se emplean desde hace más de 4000 años. En la actualidad se hallan presentes en la mayor parte de los alimentos industrializados, ya que incrementan su atractivo a los ojos de los consumidores. Un color estable y llamativo constituye un atributo de alto valor añadido en el competitivo mercado de las industrias elaboradoras de alimentos (Fernández y Giménez, 2013).

De acuerdo con su origen o procedencia, los colorantes pueden clasificarse en tres grandes grupos: 1) Los pigmentos naturales, que son generados por vegetales o animales, o bien encontrados en minerales. 2) Los idénticos a los naturales, que se obtienen por síntesis química, pero conservan características semejantes al natural. 3) Los colorantes sintéticos, que se producen exclusivamente por síntesis química. Entre los colorantes amarillos y rojos sintéticos usados como aditivos en alimentos destacan el amarillo quinoleina (E-104), amarillo anaranjado (E-110), tartrazina (E-102), azorrubina/ carmoisina (E-122), ácido carmínico (E-120), rojo ponceau 4R (E-124), rojo 40 ó rojo allura AC (E-129). Las autoridades sanitarias han restringido el permiso de uso de un gran número de aditivos coloridos. A finales de la década de los 90’s la Administración de Alimentos y Medicamentos (FDA, por sus siglas en inglés) redujo la lista de 700 a 7 colorantes sintéticos autorizados; mientras la EFSA, por sus siglas en inglés (Agencia de Seguridad Alimentaría de la Unión Europea), ha recomendado minimizar en general el agregado de aditivos, permitiendo su uso solamente cuando haya una necesidad real vinculada con la preservación, sabor o estabilidad de los alimentos. En el caso de los colorantes en 
particular, se aprobó como protocolo que las empresas incorporen en la etiqueta de sus productos una advertencia sobre probables problemas de toxicidad en el caso de ingerir 6 de los colorantes sintéticos permitidos (Downham y Collins, 2000; McCann et al., 2007; Fernández y Giménez, 2013).

Por ello, en los últimos años se ha aumentado la demanda de consumo de pigmentos amarillos y rojos provenientes de fuentes naturales, debido a las pequeñas cantidades que se utilizan en los alimentos, así como por la seguridad en relación con la salud de los consumidores (Fernández y Giménez, 2013). En 1994 el mercado global de colorantes era de alrededor 265 millones de dólares y, los colorantes naturales representaron el 25 \%. En el 2000 esta cifra aumento a 1000 millones de dólares, ocupando los pigmentos naturales el 65 \% del mercado mundial (Henriette y Azeredo, 2009). En 2011 las ventas ascendieron a 1550 millones, estableciéndose en un 70 \% el consumo de colorantes naturales. El mercado estimado para las tinturas naturales está cubierto por el amarillo-naranja (55 \%), rojos (25\%) y otros colores (20\%) (Carmona, 2013).

\section{Aplicaciones industriales}

Las betalaínas son uno de los colorantes rojos autorizados con el código 73.40 de la sección 21 CFR de la FDA y con la designación de E-162 en la Unión Europea. La disponibilidad de preparados comerciales de betalaínas se restringe a concentrados líquidos de remolacha (entre 60 y 65 \% de sólidos totales), obtenidos por evaporación rotativa de extracto fresco, o al sólido (entre el 0.3 y 1 \% de betanina) producido por atomización o liofilización del 
líquido concentrado. El extracto de remolacha se obtiene tras el blanqueado (inactivación de enzimas que puedan degradar el color), troceando, prensando y posterior filtración de tubérculos de remolacha. Los preparados comerciales no son puros, difieren en su color según la proporción de betacianinas y betaxantinas. El rendimiento de la extracción llega a los $0.5 \mathrm{~g} / \mathrm{Kg}$ peso fresco de tubérculo procesado. Se trata de un colorante potente, bastan dosis inferiores a los 50 miligramos de betanina por kilogramo de producto final para obtener el tono de color deseado (Fernández y Giménez, 2013).

A nivel mundial la remolacha de Beta vulgaris es la principal materia prima natural para la fabricación de colorantes rojos, rosas y violetas para su uso en productos alimentarios (Villegas et al., 1983; Junqueira-Goncalves et al., 2011). En cuanto al uso de betalaínas en cosméticos se ha encontrado que pueden sustituir a algunos colorantes rojos como el rojo de santeño, azóico rojo, el óxido de hierro y colorantes amarillos como el azóico amarillo, utilizados en lápices de labios, polvos para la cara, cremas faciales, cremas corporales, champús, geles de baño, cremas capilares. Así mismo las betalaínas al ser compuestos que absorben luz en 480 y 540 nm, pueden utilizarse para la elaboración de protectores solares para evitar que la luz del sol incida directamente sobre la piel (Maltos et al., 1999; Prudencio et al., 2008).

En Estados Unidos desde 1960 los pigmentos obtenidos a partir de la remolacha están permanentemente en la lista de colorantes aceptados para la adición en alimentos y no necesitan certificación (Villegas et al., 1983), no obstante dicho colorante presenta un sabor 
particular debido a la presencia de la geosmina y algunas pirazinas que producen aversión particularmente al agregarlo a alimentos tales como los lácteos (Tesoriere et al., 2004), por lo que se han propuesto nuevos colorantes derivados de frutos de Opuntia, así como de otras especies productoras de betalaínas (Tabla 2) (Fernández y Giménez, 2013). Tal es el caso de las betalaínas de amaranto, las cuales debido a la mayor gama de colores y sabor casi imperceptible al paladar, han comenzado a aplicarse en yogurt, helados, jaleas, aderezos, dulces, glaseados, tocino, salchichas, frutas en conserva y bebidas frías (Cai et al., 1999; Santos-Díaz et al, 2005; Moreno et al., 2008; Castellar et al., 2008).

Tabla 2. Principales especies vegetales productoras de betalaínas

\begin{tabular}{|c|c|c|c|}
\hline \multirow[b]{2}{*}{ Familia } & \multirow[b]{2}{*}{ Especie } & \multicolumn{2}{|c|}{ Betalaínas } \\
\hline & & Betacianinas & Betaxantinas \\
\hline Chenopodiaceae & Chenopodium rubrum & $\begin{array}{l}\text { Betanina } \\
\text { Celosianina }\end{array}$ & $\begin{array}{l}\text { Vulgaxantina I } \\
\text { Vulgaxantina II }\end{array}$ \\
\hline & Opuntia ficus-indica & $\begin{array}{l}\text { Betanina } \\
\text { Isobetanina }\end{array}$ & Indicaxantina \\
\hline Cactaceae & Hylocereus polyrhizus & $\begin{array}{l}\text { Betanina } \\
\text { Isobetanina } \\
\text { Phyllocactina } \\
\text { Hylocerenina }\end{array}$ & \\
\hline Amaranthaceae & Beta vulgaris & $\begin{array}{l}\text { Betanina } \\
\text { Isobetanina }\end{array}$ & $\begin{array}{l}\text { Vulgaxantina I } \\
\text { Vulgaxantina II } \\
\text { Indicaxantina }\end{array}$ \\
\hline Mmal allualede & Amaranthus sp. & $\begin{array}{l}\text { Amarantina } \\
\text { Isoamarantina }\end{array}$ & $\begin{array}{l}\text { Dopaxantina } \\
\text { Vulgaxantina I } \\
\text { Indicaxantina } \\
\text { Miraxantina V }\end{array}$ \\
\hline Aizoaceae & Lamprantus productus & Betanidina & Dopaxantina \\
\hline Nyctaginaceae & Bougainvillea sp. & $\begin{array}{l}\text { Gomfrenina I } \\
\text { Bougainvilleina V } \\
\text { Ésteres cumaricos de la } \\
\text { betanina }\end{array}$ & $\begin{array}{l}\text { Dopaxantina } \\
\text { Muscaaurina VII }\end{array}$ \\
\hline Portulacaceae & Portulaca grandiflora & & $\begin{array}{l}\text { Dopaxantina } \\
\text { Vulgaxantina I } \\
\text { Portulacaxantina II } \\
\text { Miraxantina V } \\
\text { Indicaxantina }\end{array}$ \\
\hline
\end{tabular}




\section{Estabilidad}

Cuando un compuesto es utilizado como colorante alimentario, la estabilidad del color es una de las mayores prioridades. La estabilidad de las betalaínas ha sido estudiada por varios autores en función de diversos parámetros. En cuanto al pH se encuentran estables en un extenso rango de valores (entre 3 a 7), lo que las hace especialmente aptas para ser empleadas en un amplio espectro de alimentos de acidez baja y neutra donde no se pueden usar antocianinas. Las temperaturas menores a $25^{\circ} \mathrm{C}$ promueven la estabilidad de estos pigmentos. Esta descrito el efecto adverso de la luz, la actividad de agua (aw) y el oxígeno; en condiciones anaeróbicas su oxidación es insignificante (Cai et al., 2001; Pedreño, et al., 2001; Castellar et al., 2003; Tesoriere et al., 2005; Fernández y Giménez, 2013). Otro factor negativo descrito para las betacianinas, es la presencia de enzimas degradativas en el tubérculo de B. vulgaris. Martinez-Parra y Muñoz en 1997 y 2001, establecieron el mecanismo de acción de la peroxidasa sobre betacianinas e identificaron los productos de reacción. Las actividades degradativas han sido también observadas en las amarántaceas y en Phytolacca americana (Gandía-Herrero et al., 2005a).

De acuerdo con estas características, las betalaínas se pueden utilizar en alimentos procesados con un tratamiento de calor mínimo, envasándolos y colocándolos en un lugar seco, bajo niveles reducidos de luz, oxígeno y humedad (Rayner, 1993, Von Elbe, 1977; Cai et al., 1999). Así mismo, se ha observado que es posible proteger adecuadamente a estos pigmentos naturales mediante su encapsulación. Indicaxantina, miraxantina $\mathrm{V}$ y betanidina, betalaínas con alta labilidad, fueron óptimamente encapsuladas con 
maltodextrinas con una limitada pérdida de coloración y actividad antioxidante después de seis meses de almacenamiento en diferentes condiciones de luz-oscuridad. La combinación de proporciones variables de betaxantinas y betacianinas ofrece una amplia gama de polvos de diferentes colores (Figura 10) (Gandía-Herrero et al., 2010; Gandía Herrero et al., 2013b). Además del uso de maltodextrinas, se ha estudiado el efecto de otros agentes encapsulantes como goma guar, goma arábiga, pectina, goma xantana, inulina y aislados de proteína de soya (Figura $10 \mathrm{H}$ y 11I), observándose que la encapsulación con maltodextrina presenta la mayor estabilidad, tanto en polvos almacenados a la luz como en obscuridad, abriéndose así la posibilidad del uso de estas moléculas colorantes para aplicación en la industria alimentaria, farmacéutica y cosmética (Gandía-Herrero et al., 2010; Gandía-Herrero et al., 2013; Ravichandran et al., 2014; Janiszewska, 2014; Robert et al., 2015).
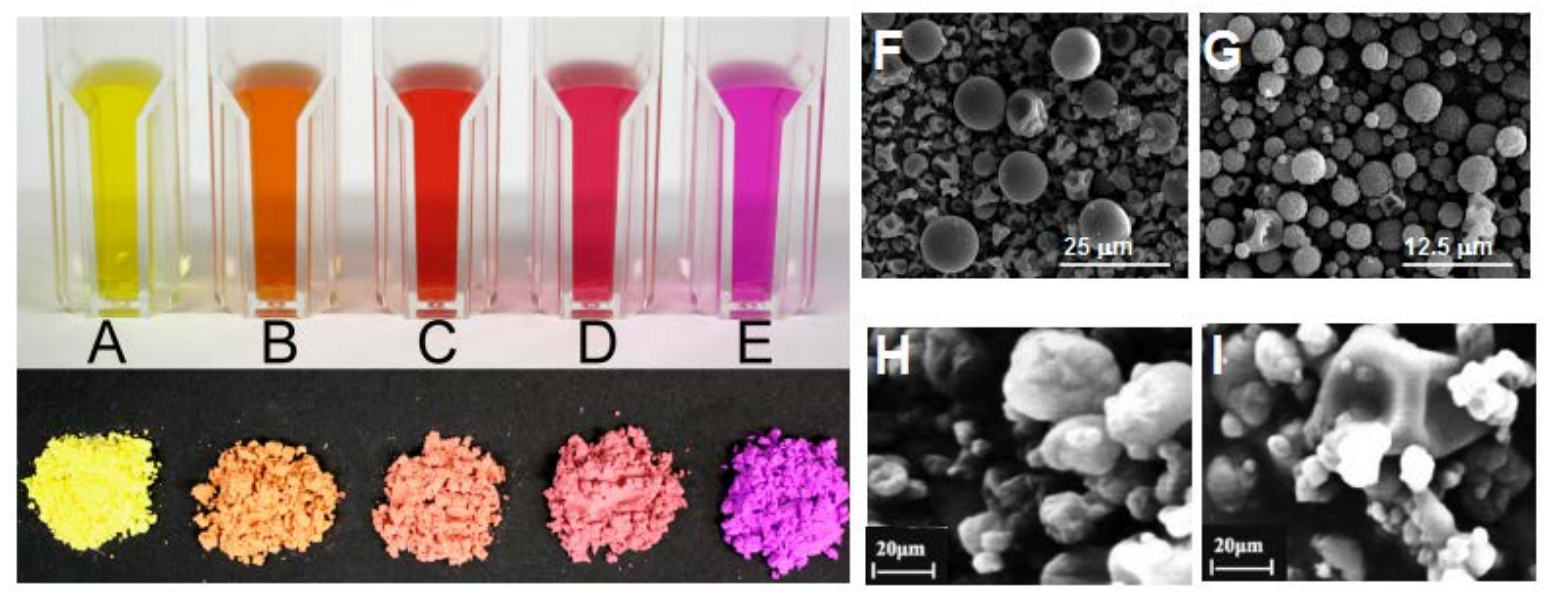

Figura 10. Encapsulados de betalaínas. Imágenes macroscópicas de combinaciones de miraxantina $\mathrm{V}$ y betanidina en forma soluble y como polvos resultantes de encapsulación con maltodextrinas. La proporción de ambos pigmentos varió de 100\% miraxantina $\mathrm{V}$ (A), 100\% betanidina (E), 75\% miraxanthin V (B), 63\% miraxantina V (C), 50\% miraxantina V (D). Imágenes de microscopia electrónica de barrido de encapsulados de miraxantina V con maltodextrina (F), quitosano (G), y extracto de Opuntia con aislado de proteína de soya $(\mathrm{H})$ y aislado de proteína de soya con maltodextrina (I). Tomado de Gandía-Herrero et al., 2013b (A-G) y Robert et al., 2015 (H-I). 


\section{Producción de betalaínas en cultivos in vitro de plantas}

El cultivo de tejidos y células vegetales es una alternativa muy atractiva para proveer compuestos bioactivos, incluyendo pigmentos del tipo betalaínas (Rao et al., 2002; Vanisree et al., 2004; Strack et al., 2003; Georgiev et al., 2008). La producción biotecnológica de colorantes alimentarios utilizando cultivos in vitro ofrece varias ventajas sobre el cultivo convencional de plantas enteras, en particular la capacidad de mantener condiciones asépticas controladas, independientemente de las variaciones del clima o las propiedades del suelo (Vanisree et al., 2004). La capacidad de definir y controlar las condiciones de producción ayuda a asegurar un suministro continuo y fácil extracción de productos con calidad y rendimiento uniforme, independientemente de la ubicación geográfica (Rao et al., 2002). Además, los colorantes producidos de esta forma se clasifican como naturales en lugar de idénticos a naturales, lo que aumenta su atractivo de consumo (Hancock 1997; Georgiev et al., 2008).

\section{Composición del medio de cultivo}

El medio de cultivo, constituye un elemento fundamental para la producción de betalaínas y la composición de éste depende de la especie a cultivar. El medio MS, o de Murashige y Skoog (1962), es el más extensamente usado en su formulación original o en numerosas variaciones. El medio B5 o de Gamborg et al. (1968) y sus derivados, también es utilizado eficazmente para la producción de betalaínas. La diferencia principal entre los medios MS 
y B5, es la menor concentración de nitratos en B5. Usualmente estos medios de cultivo incluyen sales inorgánicas, carbohidratos, vitaminas y aminoácidos. Para la producción de betalaínas el medio es suplementado con reguladores del crecimiento vegetal (RCV), los cuales se aplican de manera independiente o combinada, en concentraciones que oscilan entre 0.1 hasta $10 \mu \mathrm{M}$. Habitualmente se utiliza la citocinina 6-benzilaminopurina (BAP) y la auxina 2,4-diclorofenoxiacético (2,4-D), ya que han reportado tener efecto positivo para inducir formación de callos pigmentados y mantener suspensiones celulares coloreadas; sin embargo también se recurre a la cinétina (KIN) y al ácido naftalenacético (ANA), aunque su uso está menos extendido (Georgiev et al., 2008).

\section{Precursores y elicitores}

Se ha encontrado que la incorporación de precursores y elicitores al medio de cultivo, estimula la producción de betalaínas; como pudo comprobarse al añadir DOPA y tirosina, en suspensiones celulares de Chenopodium rubrum (Berlin et al. 1986); o al elicitar con jasmonato de metilo, sulfato de cobre y $\beta$-glucano, cultivos líquidos de Portulaca sp., Portulaca Joya, B. vulgaris y B. vulgaris var. Rubí reina, con incrementos del pigmento 2.6, 1.8, 1.4 y 2 veces, respectivamente (Mukundan et al. 1999; Bhuiyan y Adachi 2003; Suresh et al., 2004). Del mismo modo, la adición al medio de cantidades superiores a 50 g / L de sacarosa, incrementó la cantidad de betalaínas de manera similar que la elicitación con el hongo Fusarium sp., en tejido calloso de Mammillaria candida (Santos-Díaz et al., 2005). 


\section{Influencia de la luz}

La luz es otro factor importante a tomar en cuenta en la producción in vitro de estos pigmentos, su presencia favorece su acumulación en comparación con la obscuridad (Bianco-Colomas, 1980). En algunos casos los efectos de la luz depende de su longitud de onda. Por ejemplo, la luz blanca mejora la síntesis de betacianinas más que la luz UV-A (Silva et al. 2005). Se ha visto que la exposición a luz azul y UV en cultivos de callos de Portulaca sp. Joya induce la biosíntesis de betalaínas (Kishima et al. 1995). También se ha sugerido que la formación de betacianinas en cultivos en suspensión de Chenopodium album se regula por luz UV (Rudat y Göring 1995). Cuando se cultivan raíces transformadas de $B$. vulgaris bajo iluminación continua, acumulan altos niveles de betalainas (Mukundan et al. 1999), y cuando estas raíces se cultivan bajo una combinación de luz azul y radiación de color rojo, se mejora la acumulación de betacianinas y betaxantinas (Shin et al., 2003).

\section{Sistemas de cultivo establecidos}

Entre los sistemas in vitro descritos para la producción de betalaínas a partir de diferentes especies de plantas, de manera general se cita la obtención de callos amarillos (ricos en betaxantinas) y/o rojos y suspensiones de células color violeta (ricas en betacianinas) (Tabla 3). Elliot y Murray en 1975 desarrollaron cultivos de callo de Amaranthus tricolor, demostrando que una amplia gama de bases de purina, nucleósidos y nucleótidos cíclicos, actúan como análogos de citocininas, lográndose inducir la síntesis de betacianinas. Berlin et al., en 1986 obtuvieron de C. rubrum callos y suspensiones con alto contenido de 
amarantina. Böhm et al., en 1991 establecieron con Portulaca grandiflora líneas celulares de callo productoras de altas concentraciones de betaxantinas, así como callos con fenotipo naranja, rojo y violeta. De manera similar Girod y Zryd en 1991, obtuvieron de remolacha roja, líneas celulares de callo amarillo, anaranjado, rojo y violeta utilizando concentraciones bajas de 2,4-D y BAP en medios MS modificados, reportando que la metilación del ADN de las células por 5-azacitidina y la poliADP-ribosilación por 3-metoxibenzamida juega un papel clave en la represión de genes que codifican enzimas implicadas en la biosíntesis de betacianinas (Figura 11F-L). Partiendo del trabajo de Girod y Zryd, Cueros et al., en 1992, produjeron suspensiones celulares de color violeta con mayor contenido de betacianinas en comparación con el material vegetal de partida. Heuer et al., en 1996, establecieron suspensiones celulares rojas de Dorotheanthus bellidiformis (Figura $11 \mathrm{M}$ ), en donde identificaron las enzimas betanidina 5-O- y 6-O-glicosiltransferasas (5-GT y GT-6). En 1998 Schliemann et al., a partir de Portulaca grandiflora lograron desarrollar callos rojos, utilizando DOPA como sustrato. Akita et al., en 2000, obtuvieron callos amarillos y rojos de B. vulgaris cv. Detroit, estableciendo cultivos en suspensión productores de betacianinas. En 2005, Santos-Díaz et al., obtuvieron tejido calloso de Mammillaria candida, en donde demostraron que el estrés biótico y abiótico aumenta la producción de betacianinas. En 2011 Zhao et al., obtuvieron cultivos de callo de tonalidades amarillas y rojas de Suaeda salsa, reportando que 2,4-D y BAP actúan sobre la expresión del gen de DODA, favoreciendo la acumulación de betalaínas. Radfar et al., en 2012 partiendo de explantes de tallo de Zaleya decandra establecieron callos de color rosa y amarillo (Figura 11A). En 2013 Biswas et al., a partir de explantes de tallo de Amaranthus tricolor, y 
utilizando medio MS suplementado con concentraciones bajas de ANA y 2,4-D, desarrollaron líneas de callo rojo-violeta, rosa y/o amarillo (Figura 11C y 12D), informando la presencia de amarantina, isoamarantina y una betaxantina metilada derivada de arginina. Jamilah et al., en 2014 utilizando medio MS adicionado con BAP, obtienen cultivos in vitro de Celosia cristata de color anaranjado a partir de explantes de hoja (Figura 11B).
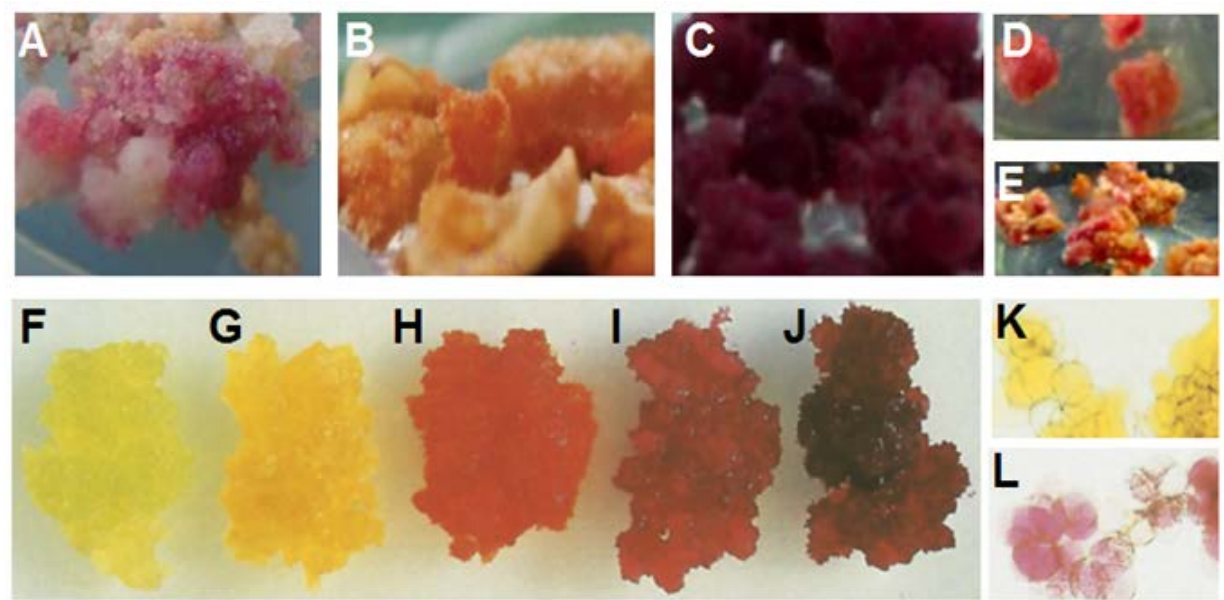

$L$
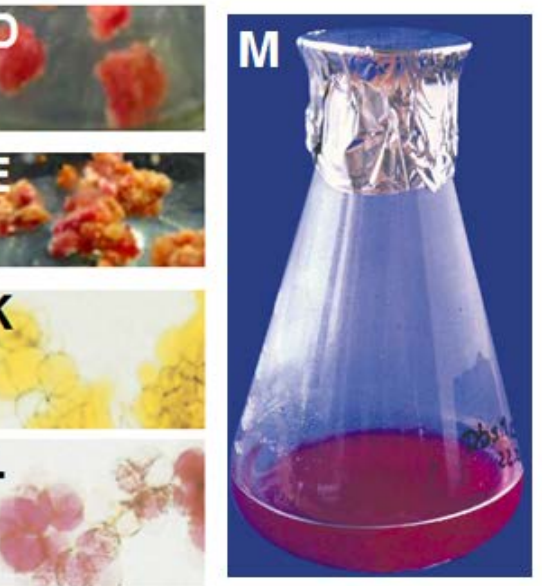

Figura 11. Producción de betalaínas en sistemas in vitro. Características fenotípicas de tejido calloso de Zaleya decandra (A); Celosia cristata (B); Amaranthus tricolor (C-F); Beta vulgaris (FJ). Microscopia de células de callo amarillo (K) y rojo (L) de Beta vulgaris. Suspensiones celulares de Dorotheanthus bellidiformis (M).

El sistema de producción in vitro de betalaínas, más utilizado es de suspensiones celulares de raíces transformadas de remolacha roja y amarilla (Beta vulgaris) obtenidas por Agrobacterium (Figura 12) (Taya et al. 1992; Jiménez-Aparicio y Gutiérrez-López 1999; Mukundan et al. 1999; Pavlov et al. 2002; Georgiev et al., 2008). La elección de cultivares apropiados es importante para obtener líneas de raíces transformadas altamente productoras de betalaínas, ya que pueden existir variaciones en la morfología celular, tasa de crecimiento y ramificación del cultivo, asociadas a su transformación (Taya et al. 1992). 
Tabla 3. Producción de betalaínas en cultivos in vitro de plantas

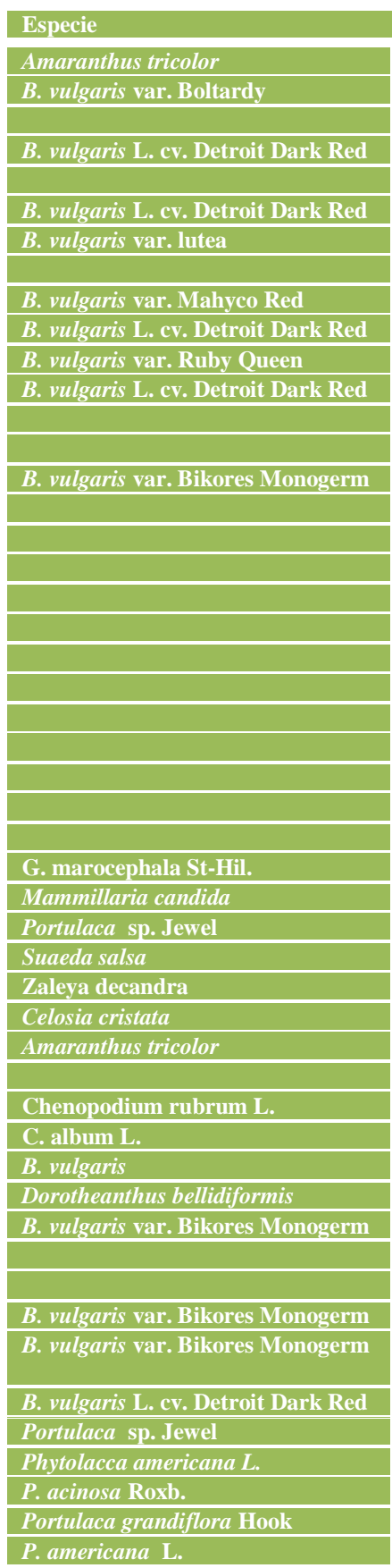

\begin{tabular}{|c|}
\hline Cultivo in vitro \\
\hline Cultivo de callo \\
\hline R. transformadas \\
\hline R. transformadas \\
\hline R. transformadas \\
\hline R. transformadas \\
\hline R. transformadas \\
\hline R. transformadas \\
\hline R. transformadas \\
\hline R. transformadas \\
\hline Cultivo de Callo \\
\hline Fenotipo amarillo \\
\hline Fenotipo anaranjado \\
\hline Fenotipo rojo \\
\hline Fenotipo violeta \\
\hline Cultivo de Callo \\
\hline Cultivo de Callo \\
\hline Cultivo de Callo \\
\hline Cultivo de Callo \\
\hline Cultivo de Callo \\
\hline Cultivo de Callo \\
\hline Cultivo de Callo \\
\hline C. en suspensión \\
\hline C. en suspensión \\
\hline C. en suspensión \\
\hline C. en suspensión \\
\hline C. en suspensión \\
\hline Fenotipo anaranjado \\
\hline Fenotipo violeta \\
\hline C. en suspensión \\
\hline C. en suspensión \\
\hline C. en suspensión \\
\hline C. en suspensión \\
\hline C. en suspensión \\
\hline C. en suspensión \\
\hline C. en suspensión \\
\hline C. en suspensión \\
\hline
\end{tabular}

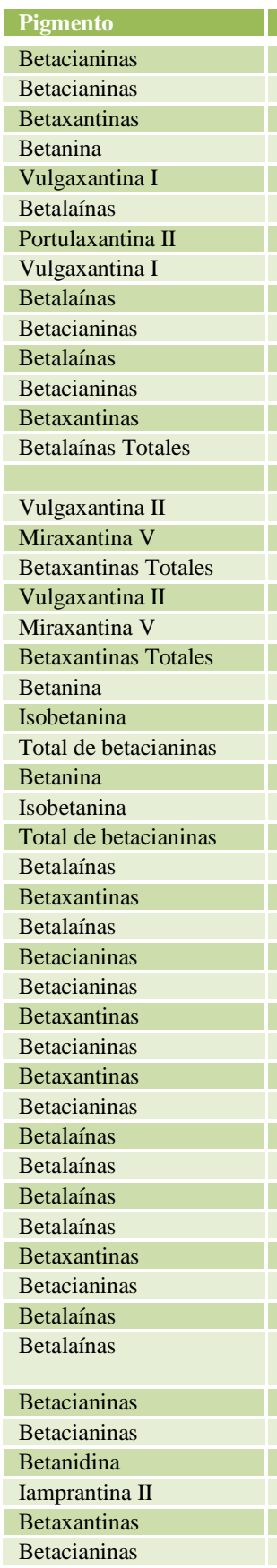

\begin{tabular}{|c|c|}
\hline Contenido & \\
\hline- & Elliot y Murray (1975) \\
\hline $0.7 \mathrm{mg} \mathrm{g}^{-1} \mathrm{FW}$ & Hamill et al. (1986) \\
\hline $1.3 \mathrm{mg} \mathrm{g}^{-1} \mathrm{FW}$ & \\
\hline $6.1 \mathrm{mg} \mathrm{g}^{-1} \mathrm{DW}$ & Taya et al. (1992) \\
\hline $9.3 \mathrm{mg} \mathrm{g}^{-1} \mathrm{DW}$ & \\
\hline $2.9 \mathrm{mg} \mathrm{g}^{-1} \mathrm{DW}$ & Weathers y Zobel (1992) \\
\hline - & Hempel y Bohom (1997) \\
\hline- & \\
\hline $7.34 \mathrm{mg} \mathrm{g}^{-1} \mathrm{DW}$ & Makundan et al. (1998) \\
\hline $18.5 \mathrm{mg} \mathrm{g}^{-1} \mathrm{DW}$ & Shin et al. (2002) \\
\hline $11.4 \mathrm{mg} \mathrm{g}^{-1} \mathrm{FW}$ & Timmaraju et al. (2003) \\
\hline $10 \mathrm{mg} \mathrm{g}^{-1} \mathrm{DW}$ & Pavlov et al. (2003) \\
\hline 14.7 mg g-1 DW & \\
\hline $24.7 \mathrm{mg} \mathrm{g}^{-1} \mathrm{DW}$ & \\
\hline & Girod y Zryd (1991) \\
\hline $1.813 \mu \mathrm{M} \mathrm{g}^{-1} \mathrm{DW}$ & \\
\hline $1.177 \mu \mathrm{M} \mathrm{g}^{-1} \mathrm{DW}$ & \\
\hline $4.278 \mu \mathrm{M} \mathrm{g}^{-1} \mathrm{DW}$ & \\
\hline $5.519 \mu \mathrm{M} \mathrm{g}^{-1} \mathrm{DW}$ & \\
\hline $3.061 \mu \mathrm{M} \mathrm{g}^{-1} \mathrm{DW}$ & \\
\hline $12.21 \mu \mathrm{M} \mathrm{g}^{-1} \mathrm{DW}$ & \\
\hline $8.69 \mu \mathrm{M} \mathrm{g}^{-1} \mathrm{DW}$ & \\
\hline $0.72 \mu \mathrm{M} \mathrm{g}^{-1} \mathrm{DW}$ & \\
\hline $11.22 \mu \mathrm{M} \mathrm{g}^{-1} \mathrm{DW}$ & \\
\hline $22.63 \mu \mathrm{M} \mathrm{g}^{-1} \mathrm{DW}$ & \\
\hline $2.90 \mu \mathrm{M} \mathrm{g}^{-1} \mathrm{DW}$ & \\
\hline $28 \mu \mathrm{M} \mathrm{g}^{-1} \mathrm{DW}$ & \\
\hline- & Vieira et al. (1895) \\
\hline- & Santos- Díaz et al (2005) \\
\hline $8.5 \mathrm{ng} \mathrm{g}^{-1} \mathrm{FW}$ & Kishima et al. (1995) \\
\hline - & Zhao et al. (2011) \\
\hline- & Radfor et al. (2012) \\
\hline - & Taha y Wafa (2012) \\
\hline- & Biswas et al. (2013) \\
\hline - & \\
\hline $55 \mu \mathrm{M} \mathrm{g}^{-1} \mathrm{DW}$ & Berlin et al. (1986) \\
\hline - & Rudat y Goring (1995) \\
\hline $2.6 \mu \mathrm{M} \mathrm{g}^{-1} \mathrm{DW}$ & Bokern et al. (1991) \\
\hline - & Heuer et al. (1996) \\
\hline - & Leathers et al. (1992) \\
\hline $10 \mathrm{mg} \mathrm{g}^{-1} \mathrm{DW}$ & \\
\hline $28 \mathrm{mg} \mathrm{g}^{-1} \mathrm{DW}$ & \\
\hline $12-35 \mathrm{mg} \mathrm{g}^{-1} \mathrm{DW}$ & Khlebnikov et al. (1995) \\
\hline $4.2 \mathrm{mg} \mathrm{g}^{-1} \mathrm{DW}$ & $\begin{array}{l}\text { Rodríguez-Monroy et al. } \\
\text { (1994) }\end{array}$ \\
\hline $7.9 \mathrm{mg} \mathrm{g}^{-1} \mathrm{DW}$ & Akita et al. (2000) \\
\hline $5.3 \mathrm{mg} \mathrm{g}^{-1} \mathrm{FW}$ & Bhuiyan y Adachi (2003) \\
\hline - & Schliemann et al. (1996) \\
\hline - & \\
\hline- & Bohm et al. (1991) \\
\hline - & Sakuta et al. (1991) \\
\hline
\end{tabular}

*Tomada y modificada de Georgiev et al., 2008. 
Se ha informado que líneas de raíces transformadas obtenidas de cuatro cultivares diferentes de B. vulgaris (cvs. Detroit, Dark Red, Egipto, Bordo y Detroit 2), acumulan desiguales niveles de betalaínas: 13.2, 5.0, 3.1 y 3.7 mg/g L (peso seco) respectivamente (Pavlov et al. 2002). Además la edad del inóculo y la duración de los periodos de subcultivo influyen fuertemente en el crecimiento las tasas de formación del producto (Pavlov et al., 2003). La principal desventaja de estos cultivos in vitro es la presencia del ADN del plásmido bacteriano en sus genomas y la necesidad de utilizar sistemas de fermentadores complejos para su cultivo (Figura 12A). Sin embargo se ha reconocido el uso de biorreactores como alternativa viable, para la producción a gran escala de estos metabolitos (Rodríguez-Monroy y Galindo, 1999; Georgiev et al., 2008).

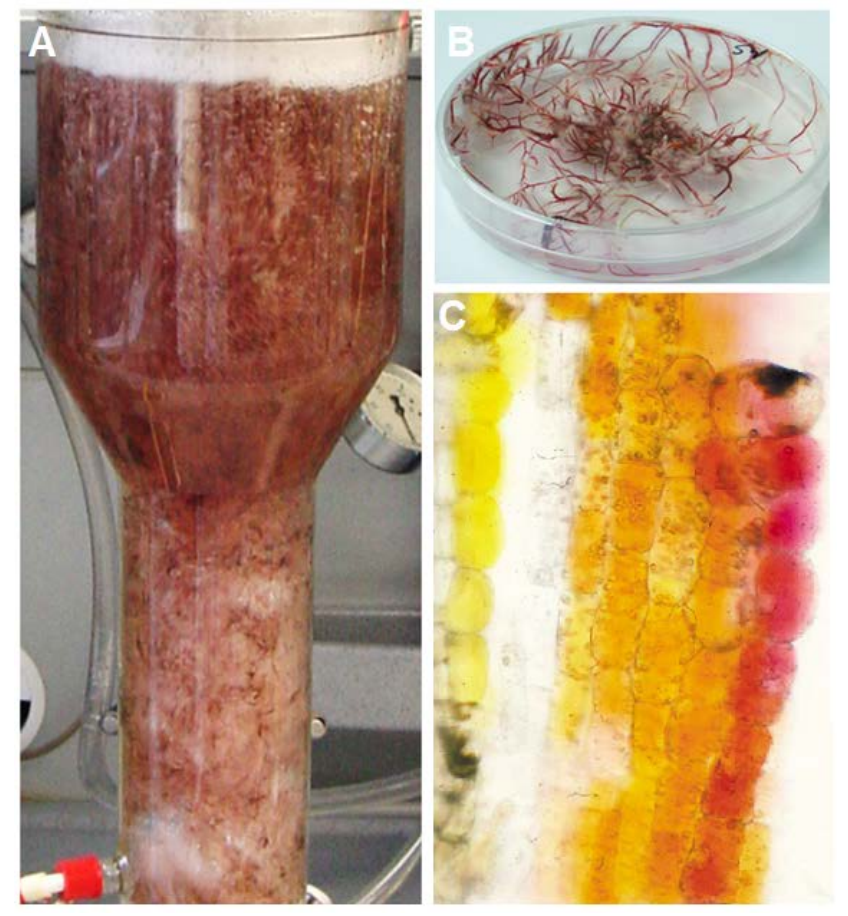

Figura 12: Cultivo de raíces transformadas de Beta vulgaris en columna de burbujeo (A) y placa de agar (B). Localización de betacianinas (pigmentos rojos) y betaxantinas (pigmentos amarillos), en la sección longitudinal de raíces transformas de remolacha amarilla. Imágenes A y B tomadas de http://tudresden.de/die_tu_dresden/fakultaeten/fakultaet_maschinenwesen/ilb/projekte. Imagen C tomada de Strack et al., 2003. 


\section{Betalaínas en la familia Amaranthaceae}

Como se mencionó en un inicio las betalaínas se distribuyen sólo en las plantas Caryophyllales (Piattelli y Minale, 1964; Cai et al., 2005), orden al que pertenece la familia Amaranthaceae, la cual contiene varios géneros importantes como Beta, Amaranthus, Celosia, Gomphrena, e Iresine (Wheeler, 1992; Cai et al., 2005). Piattelli y Minale investigaron diversos tipos de betacianinas de 16 especies de seis géneros de la familia Amaranthaceae (Piattelli y Minale, 1964). Huang y Hwang (1981) aislaron e identificaron las betacianinas (amarantina e isoamarantina) de hortalizas de amaranto (Amaranthus tricolor). Heuer et al., identificaron betacianinas (gomfreninas e isogomfreninas) de flores de Gomphrena globosa (Heuer et al., 1992). Cai y colaboradores lograron separar, identificar y cuantificar betalaínas de 37 especies de 8 géneros de la familia Amaranthaceae. Particularmente del género Amaranthus por ser considerado una fuente alternativa de pigmentos, ya que algunos genotipos de este género producen considerable biomasa, obteniéndose valiosos rendimientos de betalaínas. También lograron caracterizar 16 betacianinas de color rojo-violeta 8 del tipo amarantina, 6 gomfrenina y 2 betanina (Tabla 4), entre las que se encontraron betacianinas simples (libres de acilación) y betacianinas aciladas como betanina 5-O- $\beta$-glucuronosil-glucósido, betanidina 6-O- $\beta$ glucósido acilado con ácido ferúlico, ácido p-coumarico ó ácido 3-hidroxi-3metilglutárico. Las betaxantinas aisladas fueron dopamina-betaxantina, 3-metoxitiraminabetaxantina y (S) triptófano-betaxantina (Tabla 5), descritas en el género celosía (Cai et al., 
2005), donde también se encontraron 2-descarboxi-betanidina, así como dopamina libre (Schliemann et al., 2001).

La familia Amaranthaceae fue descrita por Antoine-Laurent de Jussieu, en 1789. Comprende alrededor de 160 géneros y 2.400 especies. Están representadas como herbáceas o arbustos, anuales o perenes, con hojas alternas u opuestas. Presentan inflorescencias en espigas o glomérulos globosos, densamente bracteadas, frecuentemente formando espigas o panículas compuestas. Poseen tépalos pequeños escariosos, generalmente libres y blanquecinos. Contienen alrededor de 5 estambres, opuestos a los tépalos, filamentos parcial o completamente en forma de cono, generalmente con lóbulos, alternos con las anteras. Tienen óvario súpero locular, de uno a tres estigmas y varios estilos; placentación basal, con presencia de uno o varios óvulos. El fruto se presenta en forma de cápsula, nuez pequeña o baya (Müller y Borsch, 2005; Judd et al., 2007).

La distribución de la familia Amaranthaceae es cosmopolita, con especies tropicales centradas en África, América y Asia. Los usos de estas plantas son muy variados. Por ejemplo, el cultivo del género Amaranthus sp., comúnmente se utiliza para la obtención de pseudocereales; el género Celosia sp., tiene aplicaciones ornamentales (Judd et al., 2007; Müller y Borsch, 2005). Recientemente se han reportado múltiples usos terapéuticos y medicinales de diferentes especies pertenecientes a esta amplia familia (Rahman-Mahbubu y Gulshana-Ara, 2014). 
Tabla 4. Estructura química y betacianinas del tipo amarantina identificadas en Amaranthaceae

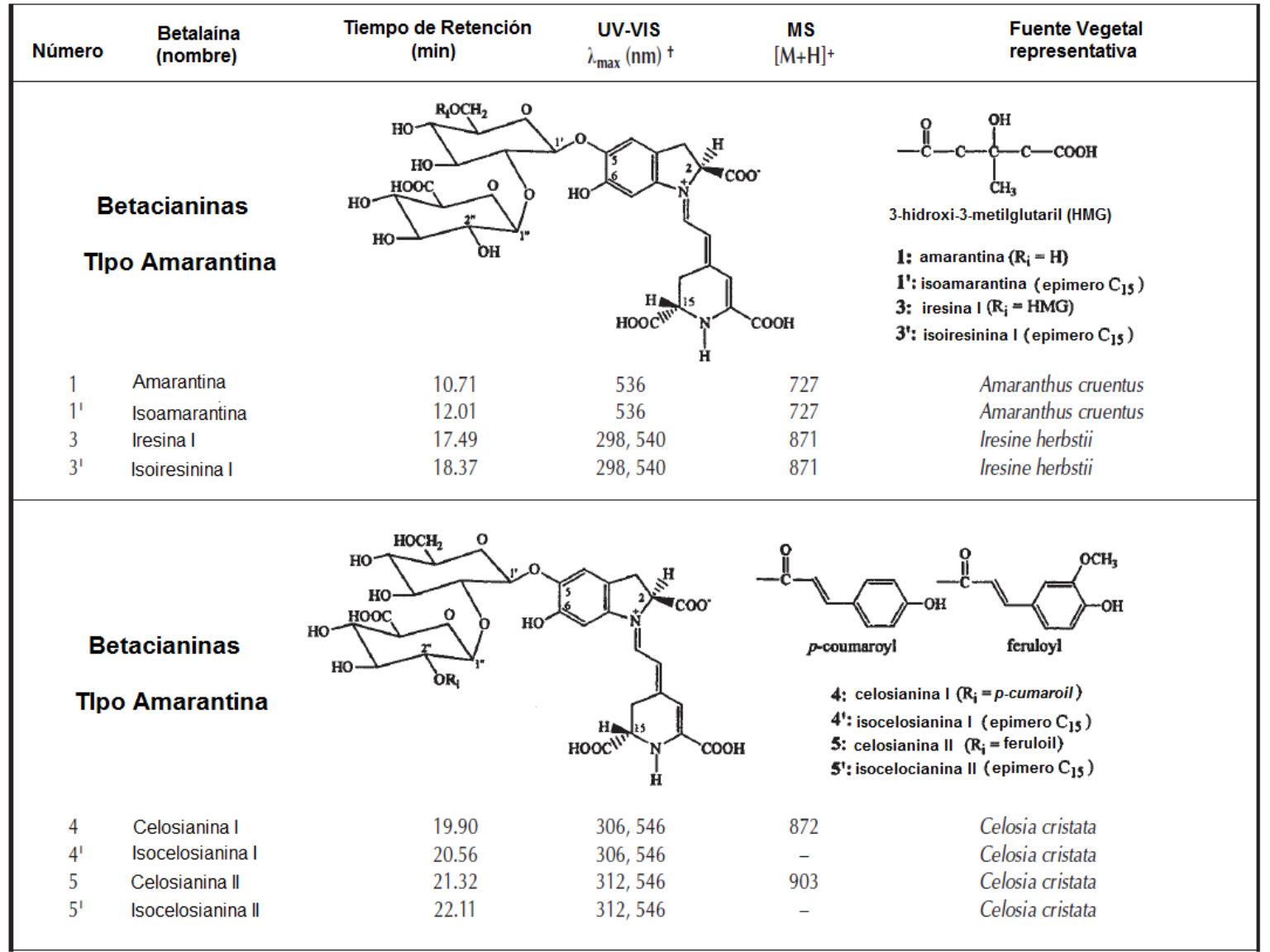

*Tomada y modificada de Cai et al., 2005 
Tabla 5. Estructura química y betacianinas del tipo gomfrenina, betanina y betaxantinas identificadas en Amaranthaceae.

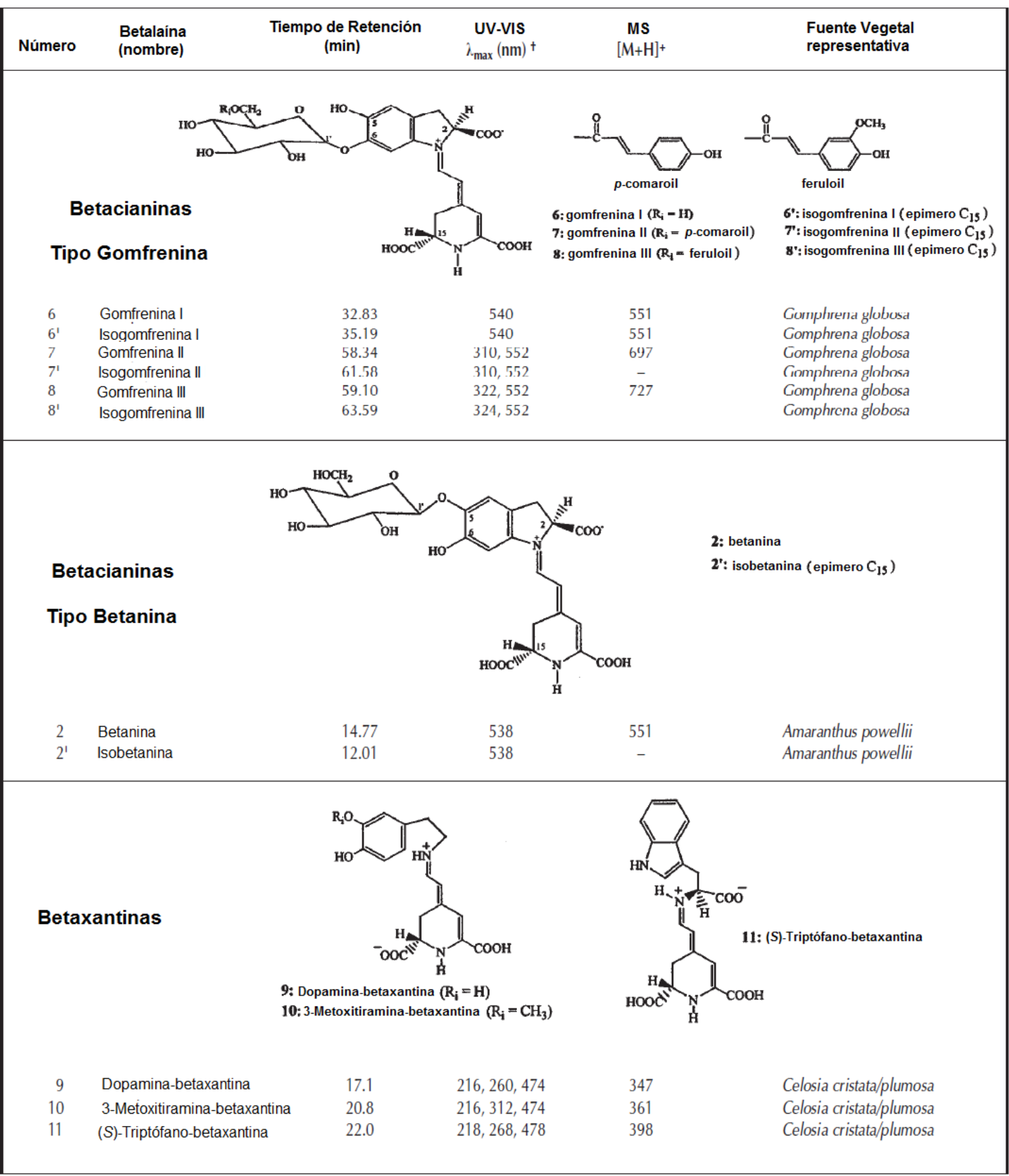

*Tomada y modificada de Cai et al., 2005 


\section{Amaranthus hypochondriacus}

La especie A. hypochondriacus variedad nutrisol, pertenece a las dicotiledóneas C4 (Figura 13A y C). Fue descrita por Carlos Linneo en 1753. La palabra Amaranthus procede del griego amaranthos, que significa "flor que no se marchita" y del epíteto hypochondriacus. A. hypochondriacus es una planta ornamental y medicinal propia y exclusiva de México, distribuida en el Centro y Sur de América y Asia (Pedersen, 1987; CONABIO, 2009). Destaca por su capacidad para tolerar condiciones de estrés y producir semillas de alto valor nutracéutico. Las semillas de amaranto son apreciadas por su capacidad para resistir estrés por sequía y salinidad con mayor eficiencia que muchos otros cultivos C3 y C4. Su tolerancia a la sequía también se atribuye a las ventajas fisiológicas conferidas por la vía C4, un hábito de floración indeterminada, crecimiento de las raíces primarias largas y extensas y sistemas de raíces laterales en respuesta a la escasez de agua en el suelo, la acumulación de osmolitos y la expresión de genes que codifican para la eliminación de especies reactivas de oxígeno, estabilizantes de proteínas y factores de transcripción (Casique-Arroyo et al., 2014)

A. hypochondriacus es una de las aproximadamente 70 especies que comprenden el género Amaranthus. La pigmentación de esta especie se debe predominantemente a dos betacianinas: amarantina, la forma más abundante y su isómero isoamarantina (Tabla 4). Ambos son 5-O-glucuroindoglucósidos de dos agliconas: betanidina e isobetanidina (su epímero C-15) respectivamente (Cai et al., 2001; Strack et al., 2003; Cai et al., 1998). 
Un análisis de genes y enzimas claves de la ruta biosintética de betacianinas en Amaranthus hypochondriacus (Ah), generó una agrupación de proteínas semejantes a las ya reportadas. La única excepción fue la enzima AhDODA-2, la cual mostró similitudes con las proteínas DODA presentes en las especies productoras de antocianinas, que no pertenecen al orden Caryophyllales. Este hallazgo podría tener implicaciones evolutivas y fisiológicas importantes. También fueron relevantes los resultados que indican que la acumulación del pigmento no siempre se correlaciona con los niveles de expresión génica y/o actividad de la tirosinasa. Esta discrepancia permite ver que ese trata de un genotipo dependiente y específico del tejido, que además puede ser influenciado por el tipo de estrés aplicado a la planta (Casique-Arroyo et al., 2014).

En 2014 fue secuenciado el genoma y transcriptoma de Amaranthus hypochondriacus, un diploide $(2 \mathrm{n}=32)$ (Figura $13 \mathrm{~B})$, con un tamaño de genoma estimado de $466 \mathrm{Mb}$. De los 411 polimorfismos, un solo nucleótido de vinculación (SNPs), representa 355 SNPs (86\%) y el 74\% de las 8600 millones de bases del mapa del transcriptoma secuenciado están vinculadas a los andamios del genoma; el cual codifica para al menos 24.829 proteínas. Comparte paleohexaploidía con especies del súper orden Magnoliopsida y Asteridae (Figura 13 C). Alberga un SNP en 1000 bases y contiene $13.76 \%$ de elementos de repetición (Meeta et al., 2014), lo cual representa un avance clave en el estudio de esta especie, ya que ofrece herramientas para comprender los diversos fenotipos que son exclusivos del amaranto, incluyendo el perfil nutricional, su comportamiento como maleza, 
su resistencia a diferentes tipos de estrés y caracterizar los genes implicados en la biosíntesis de betalaínas.
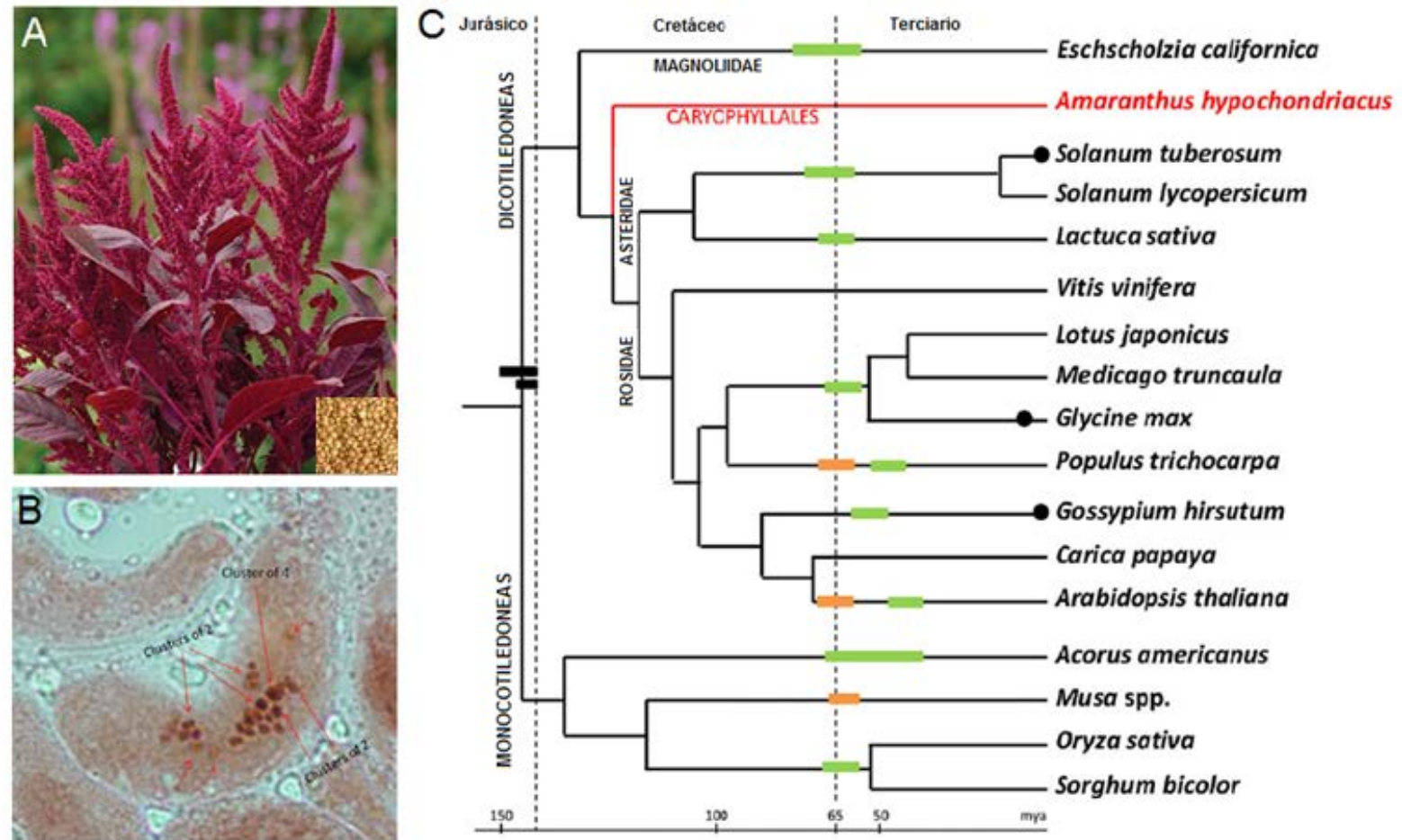

Figura 13: Amarantus hypochondriacus. (A) Características fenotípicas de la parte aérea de la planta y sus semillas en la variedad nutrisol (B) Cariotipo mostrando la diploidía con 32 cromosomas en regiones mitóticas de la raíz de la planta. (C) Árbol filogenético comparando eventos de duplicación de todo el genoma en muchas especies, incluyendo A. hypochondriacus. Imágenes B-C tomadas de Meeta et al., 2014.

\section{Celosia argentea}

Celosia argentea variedad plumosa, fue descrita por Carlos Linneo en 1753; es una herbácea anual, dicotiledónea C4 (Figura 14). Su nombre deriva del griego kelos "quemado", y del epíteto latino argéntea "plateada” (Pedersen, 1987). 

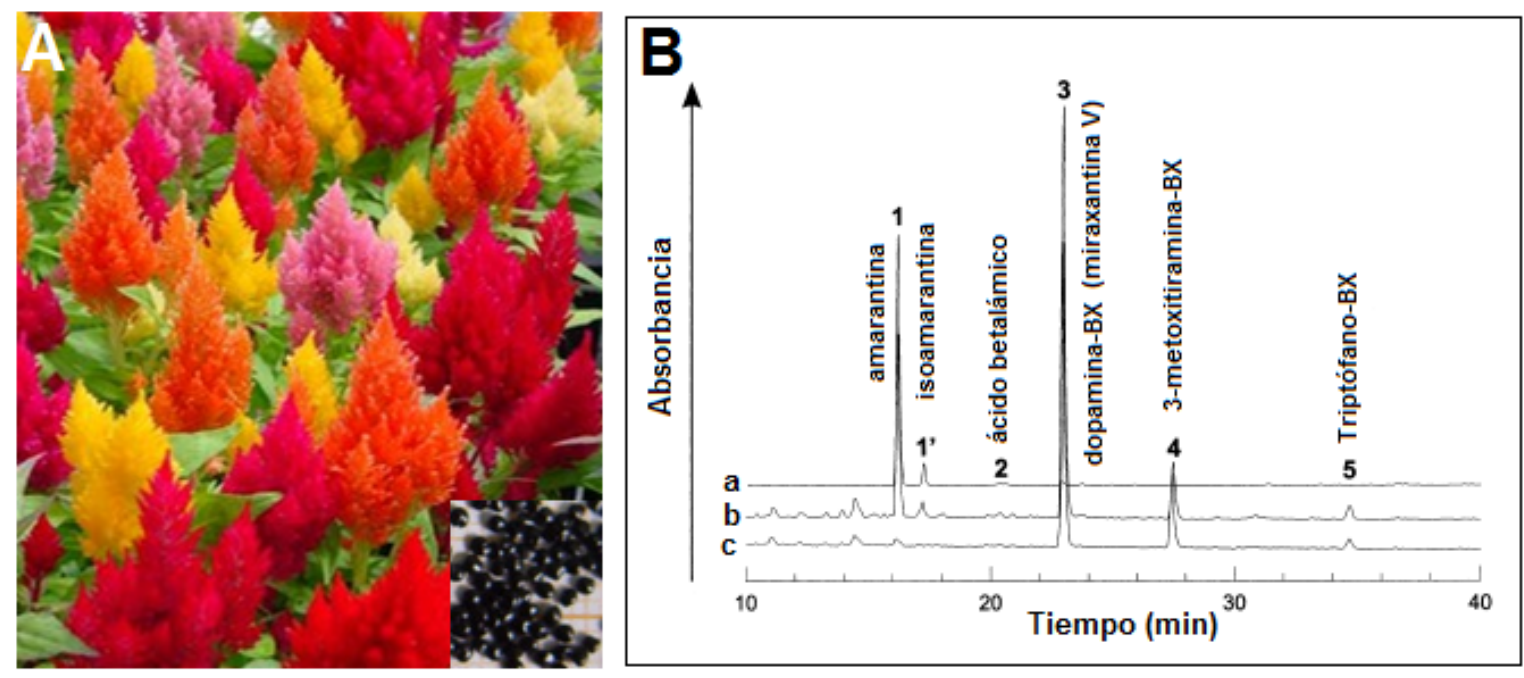

Figura 14. Celosia argentea. (A) Características fenotípicas de la parte aérea de la planta y sus semillas en la variedad plumosa. (B) Perfiles de elución en HPLC de betalaínas presentes en: a) inflorescencias rojas (400-650 nm; de escala completa: $1.55 \mathrm{UA}$ ); b) inflorescencias anaranjadas (470 nm; a gran escala: 0,255 UA); c) inflorescencias amarillas (470 nm; de escala completa: 0,185 UA). Imagen B tomada y modificada de Schliemann et al., 2001.

Celosia argentea es una de las 60 especies que conforman el género Celosia. Es nativa de las zonas subtropicales y templadas de África, Centro y Sur de América y el Sudeste Asiático, sin embargo es una especie ampliamente extendida debido a su uso ornamental (Taha y Wafa, 2011; Ahmad y Dole; 2014). También se ha documentado su aplicación como planta medicinal, haciendo uso de extractos del vegetal entero o de las inflorescencias para tratar diabetes mellitus, cáncer, enfermedades epiteliales, respiratorias, inflamatorias como artritis reumatoide, trastornos hepáticos, gastrointestinales, hematológicos y ginecológicos (Priya et al., 2004, Ramesh et al., 2013). Sus propiedades medicinales se han asociado a la gran variedad de constituyentes que presenta, entre los 
que se encuentran altas concentraciones de dopamina y betalaínas. La variación de colores de las inflorescencias depende de contenido de betalaínas. Tonos amarillos corresponden a la presencia de dopamina-betaxantina, 3-metoxitiramina-betaxantina y (S) triptófanobetaxantina (Tabla 4), tonos violetas se deben al contenido de amarantina, betanina y sus respectivos isómeros (Tabla 5), tonos rojos y anaranjados ocurren de la combinación de betaxantinas y betacianinas en diferentes proporciones (Figura 14) (Schliemann et al., 2001; Cai et al., 2005). 
Capítulo 3. JUSTIFICACIÓN 


\section{JUSTIFICACIÓN}

Los colorantes sintéticos han sido ampliamente utilizados sobre los pigmentos naturales por su gran capacidad tintórea, estabilidad y bajo costo de producción. Se ha observado que estos colorantes, provocan efectos adversos en la salud, como trastornos gastrointestinales, hepáticos, alteraciones de conducta y aprendizaje (Downham y Collins 2000, Biswas et al., 2013). Por tal motivo, a finales de los años 90 la FDA redujo la autorización del uso de colorantes sintéticos de 700 a 7 los colorantes sintéticos autorizados. Actualmente la EFSA sólo permite el uso de aditivos coloridos, cuando existe necesidad real vinculada con la preservación, sabor o estabilidad de los alimentos (Downham y Collins, 2000; McCann et al., 2007; Fernández y Giménez, 2013). Lo anterior se ha visto reflejado en el mercado global de colorantes, ya que en 2011 ascendió a 1550 millones de dólares, correspondiendo el $70 \%$ a tinturas naturales (Carmona, 2013); entre estas las betalaínas han despertado gran interés en la industria, debido a las ventajas que presentan con respecto a las antocianinas y carotenoides, como son su hidrosolubilidad, sus tonalidades amarillas (betaxantinas) y violetas (betacianinas), su estabilidad en medio ácido (Santos-Díaz et al, 2005). Otras características favorables de las betalaínas son su actividad antioxidante, antiinflamatoria, anticarcinogénica y neuroprotectora, reconociéndoseles como sustancias nutracéuticas (Stintzing y Carle, 2004; Henriette y Azeredo, 2009; Wang y Yang, 2010; Gandía-Herrero y García-Carmona, 2013). 
De manera natural Amaranthus hypochondriacus variedad nutrisol y Celosia argentea variedad plumosa sintetizan betalaínas, sin embargo el cultivo de ambas especies no está destinado a la producción de pigmentos. El amaranto se reserva a la obtención de grano (Mapes, 1996; Espitia-Rangel, 1991); y celosía preferentemente al uso ornamental (Taha y Wafa, 2012; Jamilah et al., 2014). Además el contenido de betalaínas en ambos vegetales es bajo ( $<1 \%$ ), ya que son metabolitos secundarios (Buchanan et al., 2000); lo que puede provocar una sobreexplotación de estas especies y de los recursos naturales para su producción. Por tanto, el establecimiento de cultivos in vitro de estas dos amarantáceas, representa una alternativa biotecnológica sustentable para obtener líneas celulares con capacidad de síntesis de betalaínas. Con las herramientas del cultivo de tejidos vegetales (CTV), la producción puede ser incrementada consiguiendo eliminarse las desventajas de la estacionalidad, las variaciones geográficas y anuales en los cultivos, así como las fluctuaciones en los rendimientos debido a enfermedades o plagas que surgen al cultivar las plantas en campo. De esta forma sería factible obtener una fuente sostenible de pigmentos naturales de interés para la industria, los cuales al ser encapsulados seguirán siendo moléculas bioactivas y funcionales, pudiéndose aplicar a diferentes productos asegurando una concentración estable de colorante. 
Capítulo 4. MATERIALES Y MÉTODOS 


\section{MATERIAL Y METODOS}

\section{Reactivos}

Productos químicos y reactivos fueron adquiridos de Sigma (St. Louis, EEUU). Los disolventes se obtuvieron de Merck Chemicals Ltd. (Dorset, Inglaterra). Acetonitrilo y metanol de grado HPLC fueron adquiridos de Labscan Ltd. (Dublín, Irlanda). El agua destilada se purificó usando un sistema Milli-Q (Millipore, Bedford, MA).

\section{Material vegetal}

En el caso de la especie Amaranthus hypochondriacus var. nutrisol, las semillas fueron proporcionadas por el Instituto Nacional de Investigaciones Forestales y Agropecuarias (INIFAP), Campo Experimental Valle de México. En el caso de la especie de Celosia argentea var. plumosa las semillas fueron obtenidas de plantas con inflorescencias violetas, adquiridas en Viveros La Generala (Murcia, España) y cultivadas en los invernaderos de la Universidad de Murcia (Murcia, sureste de España).

\section{Desinfección y germinación de semillas}

Las semillas de Amaranthus hypochondriacus, fueron sometidas a los siguientes tratamientos de desinfección: 1) lavado con detergente líquido comercial al 1 \% durante 10 y 15 min; 2) inmersión en etanol al 70\% durante 30s; 3) lavado en solución de hipoclorito de sodio al $0.6 \%, 1.2 \%, 1.8 \%$ y $0.2 \%$ de Tween-20 durante 10 y 20 min; y 4) tres enjuagues con agua estéril bajo condiciones asépticas. En esta especie, el tratamiento de 
desinfección con detergente líquido comercial 1\% durante 15 min, seguido por etanol al 70 \% durante 30 s, y solución de hipoclorito de sodio 1.8\% con $0.2 \%$ de Tween-20 durante 30 min, presentó asepsia del $100 \%$, por lo que se decidió aplicar directamente dicho tratamiento de desinfección a las semillas Celosia argentea.

Una vez realizado el proceso de desinfección, las semillas de ambas especies vegetales se transfirieron a tubos esterilizados $(25$ x150 mm) que contenían $15 \mathrm{~mL}$ de medio semisólido Murashige y Skoog (MS) (Murashige y Skoog, 1962). De las plántulas obtenidas con crecimiento aproximado de $3 \mathrm{~cm}$ en amarantoy $2 \mathrm{~cm}$ en celosía (20 días de edad) se tomaron como fuente de explante, hipocótilos y hojas de la primera especie vegetal, y sólo hipocótilos de la segunda, tomando como referencia la presencia de coloración roja en dichas estructuras.

\section{Inducción de callo}

Los explantes de hipocótilos y hojas de amaranto y los explantes de hipocótilos de celosía, se transfirieron a tubos individuales $(n=6)$, con $10 \mathrm{~mL}$ de medio MS, suplementado con 30 g / L de sacarosa y 2 g / L de phytagel como agente solidificante. Para evaluar la respuesta a callo, los medios de inducción fueron enriquecidos con diferentes concentraciones y combinaciones de reguladores de crecimiento vegetal: BAP $(0.0,2.22,4.44,6.66,8.88 \mu \mathrm{M})$ y 2,4-D (0.0, 2.26, 4.52, 6.79, $9.05 \mu \mathrm{M})$. Todos los medios de cultivo se ajustaron a pH 5.8 con $\mathrm{NaOH} 1 \mathrm{~N}$ y $\mathrm{HCl}$ y se esterilizaron en autoclave a $121^{\circ} \mathrm{C}$ durante $18 \mathrm{~min}$. Los cultivos se incubaron bajo un fotoperíodo de 16 h bajo luz fluorescente a una irradiancia de $50 \mu \mathrm{mol}$ $/ \mathrm{m}^{2} / \mathrm{s}$, y temperaturas de $23^{\circ} \mathrm{C}$ (día) y $18^{\circ} \mathrm{C}$ (noche). La respuesta de formación de callo 
de los explantes para cada uno de los tratamientos de inducción fue expresada como el porcentaje del número de hojas formando callo respecto al total de explantes evaluados, el cual fue registrado a los 30 d de cultivo. La proliferación de las líneas celulares de callo se realizó mediante subcultivos en medio fresco, cada 20 d durante 9 ciclos de subcultivo (celosía), y cada 30 d durante 21 ciclos de subcultivo (amaranto). En ambas especies vegetales dicho tratamiento dio origen a una línea celular de rápido crecimiento y formación de callo friable. En A. hypochondriacus se obtuvo una línea de callo color amarillo verdoso. En C. argentea se produjeron dos líneas de callo de color amarillo y rojo.

\section{Establecimiento de suspensiones celulares}

El cultivo en suspensión de células se inició a partir de callo friable de 3 semanas de edad de la línea celular de callo amarillo verdoso (A. hypochondriacus), y de la línea celular de callo rojo (C. argentea) mediante la transferencia de 2.5 g a matraces Erlenmeyer de 100 mL, que contenían $30 \mathrm{~mL}$ de medio de inducción (sin phytagel), suplementado con $10 \mathrm{mM}$ de ácido ascórbico en el caso de celosía. Los cultivos se incubaron bajo las mismas condiciones en un agitador orbital a 110 rpm. Después de tres subcultivos cada 15 días, las células se tamizaron a través de filtros de tela de nylon de $200 \mu \mathrm{m}$ de poro, para obtener un cultivo de suspensión celular homogénea. El cultivo se mantuvo durante 6 meses por subcultivo cada 15 días, utilizando un tamaño de inóculo celular de $10 \%$ (v / v) en matraces Erlenmeyer de $500 \mathrm{~mL}$ que contenían $100 \mathrm{~mL}$ de medio de cultivo. 


\section{Cultivo de suspensiones celulares de $A$. hypochondriacus en biorreactor de $3 \mathrm{~L}$}

En el caso de la línea celular en suspensión de amaranto, se utilizó para su cultivo, un biorreactor de vidrio de 3 L de volumen nominal (Applikon Schiedam, Holanda), provisto de una tapa de acero inoxidable con multipuertos. Los puertos se usaron para la colocación de un electrodo para $\mathrm{pH}$ y uno para oxígeno (AppliSens, Schiedam, Holanda), un termopozo, una entrada de aire, un dispositivo para tomar muestra, tres mamparas y un tablón con tres entradas; donde se colocaron dos salidas de venteo y una entrada de $\mathrm{HCl}$. En la entrada de aire, en las salidas de venteo y de toma de muestra se colocaron filtros de tamaño de poro de $0.2 \mu \mathrm{M}$ (POLICAP, Whatman, EEUU). Los electrodos de pH y oxígeno fueron conectados a un biocontrolador modelo ADI 1030 (Applikon Schiedam, Holanda), para realizar el registro y control de pH y tensión de oxígeno disuelto en el medio (TOD). La agitación de los cultivos se realizó a 400 rpm con un motor de velocidad variable y un controlador de velocidad modelo ADI 1012 (Applikon Schiedam, Holanda). El impulsor tipo Rushton se colocó a 2,6 cm, del fondo del tanque. La relación diámetro del impulsor/ diámetro del tanque fue de 0.35 .

El biorreactor de 3L conteniendo $900 \mathrm{~mL}$ del medio de cultivo MS (mismo utilizado para el mantenimiento de las células en suspensión, sin ningún suplemento), se inoculó con 300 mL de células de un cultivo de A. hypochondriacus de 8 días de cultivo, cuya relación fue al $20 \%$ de células, con respecto al volumen del medio. El biorreactor fue puesto en operación a $400 \mathrm{rpm}$ a $25 \pm 2{ }^{\circ} \mathrm{C}$ y fotoperiodo de 16 h luz/8 h obscuridad. 


\section{Cinéticas de crecimiento}

Para determinar la cinética de crecimiento en matraz de ambas especies vegetales, 2.5 g de células frescas cosechadas después de 8 días de cultivo, se inocularon en matraces Erlenmeyer de $100 \mathrm{~mL}$ que contenían $30 \mathrm{~mL}$ de medio de cultivo. En el caso de amaranto, la cinética de crecimiento en biorreactor de 3L se obtuvo siguiendo la metodología propuesta por Rodríguez Monroy y Galindo (1999). El medio de cultivo utilizado en ambos sistemas y para las dos especies, fue MS líquido suplementado con sacarosa al 30 g /L, BAP 6.66 $\mu \mathrm{M}$ y 2,4-D $6.79 \mu \mathrm{M}$. Se extrajeron alícuotas cada 3 días durante un período de 14 (amaranto) y 30 (celosía) días, a partir de matraces de cultivo y de biorreactor, para determinar el crecimiento celular, la morfología celular, la viabilidad celular, y en su caso el contenido de betalaínas y dopamina. Todos los experimentos se realizaron por triplicado ( $n=3)$ y los resultados se expresaron como valores promedio y las desviaciones estándar (SD).

\section{Viabilidad celular}

La viabilidad de las células se determinó por la prueba de tinción con azul del Evans (Rodríguez-Monroy y Galindo, 1999). Dos mililitros de muestra tanto de matraz, como de biorreactor se incubó en una solución 0.25 \% de azul de Evans, durante 5 min y luego se contaron las células en una cantidad al menos de 700; esto se repitió dos veces $(n=6)$. Se calculó la viabilidad mediante el conteo de las células que no se colorearon (células viables). 


\section{Envejecimiento de líneas celulares de Amaranthus hypochondriacus}

Dos gramos de células de callo y de suspensiones celulares de amaranto, se transfirieron a frascos tipo gerber y matraces Erlemeyer de $100 \mathrm{~mL}$, conteniendo $25 \mathrm{~mL}$ y $20 \mathrm{~mL}$ de medio sólido y líquido, respectivamente $(\mathrm{n}=6)$. El medio de cultivo y las condiciones de incubación fueron idénticos al de las línea celulares de partida. El monitoreo y toma de muestras se realizó semanalmente, dejándose envejecer los cultivos hasta completar once semanas sin subcultivo.

\section{Adición de precursores y elicitores en líneas celulares de A. hypochondriacus}

Para determinar el efecto de la adición de precursores y elicitores en la producción de betalaínas en la línea celular de amaranto, 2 g de células de callo y 2.5 g de células en suspensión de 8 días de cultivo, se transfirieron a frascos tipo gerber con $25 \mathrm{~mL}$ de medio sólido, y a matraces Erlenmeyer de $100 \mathrm{~mL}$ con $20 \mathrm{~mL}$ de medio líquido, respectivamente. Tanto para la línea de callo como para la línea en suspensión se utilizó medio MS con la misma formulación y bajo idénticas condiciones de incubación de las líneas celulares de partida. En condiciones de esterilidad, de manera individual y según el caso, los cultivos fueron inoculados con tirosina $1.5 \mathrm{mM}$, L-DOPA $1.5 \mathrm{mM}$, metiljamonato (MeJA) $100 \mu \mathrm{M}$ y ácido salicílico (SA) $10 \mathrm{mM}$. Para las suspensiones celulares y cultivos de callo, se realizaron subcultivos cada 15 y 30 días, respectivamente. Cada tratamiento constó de 3 repeticiones cada una conformada dos frascos. 


\section{Extracción y purificación del pigmento amarillo de A. hypochondriacus}

Muestras liofilizadas de A. hypochondriacus, provenientes de tejido calloso y de suspensiones celulares cultivadas a nivel de matraz y biorreactor de 3L, se extrajeron por separado con ciclo hexano (10 g /150 mL), para aislar la mayor cantidad de compuestos lipofílicos, retirándose el solvente cada 24 horas, repitiéndose este proceso tres veces. Posteriormente para obtener el pigmento amarillo, las muestras se sometieron a un proceso de extracción durante 15 horas con 50 mL de metanol al 100 \%, cambiándose el disolvente 3 veces y apartándose en recipientes protegidos de la luz. Las muestras líquidas de pigmento, fueron centrifugadas a 120000 g durante 40 minutos y extraídas en fase sólida con cartuchos C-18 de $1 \mathrm{~mL}$ (Waters, Milford, EEUU), acondicionados con $5 \mathrm{~mL}$ de metanol al $100 \%$, seguido de $5 \mathrm{~mL}$ de metanol al $30 \%$. Las muestras de pigmento amarillo en metanol al $30 \%$, se inyectaron en la minicolumna, realizándose un lavado con 5 mL de acetona al 40 \%, seguido de $5 \mathrm{~mL}$ de metanol al 30 \%. El pigmento amarillo se eluyó con metanol al $100 \%$, la fracción resultante se purifico por HPLC (apartado XVI), inyectando $100 \mu \mathrm{L}$ de muestra y obteniéndose dos fracciones de color amarillo, las cuales fueron evaporadas a sequedad bajo presión reducida a temperatura ambiente. Los residuos de ambas fracciones, se re-disolvieron en metanol al $100 \%$ y se analizaron por HPLC-ESIMS (apartado XVII). El pigmento restante se guardó a $-80{ }^{\circ} \mathrm{C}$ para posterior uso. El proceso de extracción y purificación se llevó a cabo en condiciones de obscuridad a $25{ }^{\circ} \mathrm{C}$. 


\section{Extracción de betalaínas}

En el caso de las muestras de A. hypochondriacus de cultivos de callo y suspensión sometidos a envejecimiento, las muestras fueron tomadas semanalmente hasta completar 11 semanas; en los experimentos de adición de precursores y elicitores las muestras se recolectaron cada 3 h, 6 h, 14 h, 24 h, 38 h, 48 h, 62 h, 72 h, 1, 2, 3, 4 y 8 semanas. En cuanto a las muestras de callos y de células en suspensión de Celosia argentea, fueron recogidas de 1, 8, 15 y 30 días de cultivo. Las muestras de ambas especies vegetales, se homogeneizaron manualmente en $10 \mathrm{mM}$ tampón fosfato $\mathrm{pH}$ 6.0, que contenía ácido ascórbico $10 \mathrm{mM}$. El homogeneizado y muestras del medio líquido de los cultivos en suspensión se centrifugaron a 14.000 g durante 15 min. El sobrenadante de cada muestra se utilizó para el análisis por HPLC de betalaínas, y ácido betalámico (n = 3). En el caso de celosía también se analizó la presencia de dopamina $(n=3)$. Todo el proceso se llevó a cabo a $4^{\circ} \mathrm{C}$. El porcentaje de humedad y el peso seco de las células se obtuvieron con un analizador de humedad electrónico Kern MLS (Balingen, Alemania).

\section{Estándares de betalaínas}

La betanina se obtuvo a partir de raíces de Beta vulgaris, dopaxantina se extrajo y se purificó a partir de flores amarillas de Lampranthus productus, betanidina se obtuvo de flores de color violeta de la misma planta, y amarantina se extrajo de Amaranthus spinosus (Gandía-Herrero y García-Carmona, 2013; Cai et al., 2005). Los pigmentos restantes se obtuvieron mediante un procedimiento combinado para la liberación de ácido 
betalámico y la condensación de éste con la amina de la dopamina y los aminoácidos $(S)$ glutamina y (S)- triptófano (Gandía-Herrero et al., 2006). El ácido betalámico se obtuvo mediante hidrólisis básica de la betanina (Gandía-Herrero et al., 2012). Todos los compuestos se caracterizaron por espectrofotometría, cromatografía, espectrometría de masas y ionización por electrospray (ESI-MS).

\section{Cromatografía de intercambio aniónico}

La Cromatografía de intercambio aniónico se realizó en un aparato Äkta purifier (Amersham Biosciences, Uppsala, Suecia) usando una columna de Q-Sepharose $25 \times 7 \mathrm{~mm}$ (agarosa reticulada con amonio cuaternario como grupo intercambiador, 90 micras de tamaño de partícula), con un flujo de $1 \mathrm{~mL}$. Los disolventes utilizados fueron fosfato de sodio 10 mM, pH 6.0 (disolvente A), y fosfato de sodio $10 \mathrm{mM}, \mathrm{pH} 6.0$, con $\mathrm{NaCl} 2 \mathrm{M}$ (disolvente B). Después de la inyección de la muestra, el proceso de elución fue el siguiente: 0\% de B desde el principio hasta $3 \mathrm{~mL}$, y luego un gradiente lineal se desarrolló a partir de 0\% de B a 35\% B en $20 \mathrm{~mL}$. En todos los casos, la tasa de flujo fue de $1 \mathrm{~mL} / \mathrm{min}$, se recogieron fracciones de $1 \mathrm{~mL}$ y el volumen de inyección fue de $1 \mathrm{~mL}$. Las eluciones fueron seguidas por detección UV / VIS a 280, 480 y 536 nm.

\section{Extracción de betalaínas en fase sólida con cartuchos C-18}

Se utilizaron cartuchos C-18 de $1 \mathrm{~mL}$ (Waters, Milford, MA) y se acondicionaron con 5 $\mathrm{mL}$ de etanol seguido de $10 \mathrm{~mL}$ de agua purificada. Las soluciones acuosas de pigmentos extraídos y las betalaínas semisintéticas se inyectaron en la minicolumna. Las sales y los 
tampones se eliminaron por lavado de la columna con agua purificada. Las betalaínas se eluyeron con etanol y la fracción resultante se evaporó a sequedad bajo presión reducida a temperatura ambiente. El residuo se volvió a disolver en agua para su uso posterior o se almacenaron a $-80^{\circ} \mathrm{C}$.

\section{Análisis por HPLC-DAD}

Se utilizó un aparato LC-20AD de Shimadzu (Kyoto, Japón), equipado con un detector SPD-M20A de fotodiodos en serie (PDA). Se desarrolló la cromatografía con una columna C-18 de dimensiones de $250 \mathrm{~mm} \times$ 4,6 mm, 5 m, Kromasil 100 (Teknokroma, Barcelona, España) (Gandía-Herrero et al., 2005). El disolvente A de la fase móvil, consistió de agua con ácido trifluoroacético al 0,05\% (TFA), y de un disolvente B compuesto de acetonitrilo con $0.05 \%$ de TFA. Un gradiente lineal se realizó durante 42 min de $0 \%$ de $\mathrm{B}$ a $65 \%$ de $\mathrm{B}$. Con un flujo de $1 \mathrm{~mL} / \mathrm{min}$, operado a $30^{\circ} \mathrm{C}$. Las eluciones se siguieron a $\lambda 270 \mathrm{~nm}$ (dopamina), $405 \mathrm{~nm}$ (ácido betalámico), $420 \mathrm{~nm}$ (pigmento amarillo de amaranto), $480 \mathrm{~nm}$ (betaxantinas) y $536 \mathrm{~nm}$ (betacianinas). El volumen de inyección fue de $40 \mu \mathrm{L}$. La identificación de los compuestos (dopamina y betalaínas) se realizó por comparación de los tiempos de retención y espectros de absorción con los de los patrones correspondientes y por experimentos de co-elución. 


\section{Espectrometría de masas con ionización por elecrospray}

Para el análisis de espectrometría de masas con ionización por elecrospray (HPLC-ESIMS), se utilizó un aparato 1100 VL LC / MSD Trap (Agilent Technologies, Palo Alto, CA). Las condiciones de elución fueron como se describieron anteriormente usando la misma columna (250 mm x 4,6 mm ID, 5 um, Kromasil 100 C-18), con una velocidad de flujo a $0.8 \mathrm{~mL} / \mathrm{min}$. La temperatura del vaporizador fue de $350^{\circ} \mathrm{C}$, y el voltaje se mantuvo en 3,5 kV. El gas transportador fue nitrógeno, a una presión de 45 psi. Las muestras fueron ionizadas en modo positivo. La ionización se monitorio en un rango de $m$ / z 50-1000. El voltaje del multiplicador electrónico del detector fue de $1.350 \mathrm{~V}$.

\section{Espectrometría de fluorescencia del pigmento amarillo de $A$. hypochondriacus}

Los ensayos espectrofluorimétricos del pigmento amarillo obtenido en las líneas celulares de amaranto, se llevaron a cabo en un espectrofotómetro de fluorescencia LS50B (PerkinElmer Life and Analytical Sciences, Boston, EEUU), equipado con una célula termostatizable. Las medidas fueron realizadas en metanol a $4^{\circ} \mathrm{C}$ en cubetas de cuarzo de 3 mL. El espectro de excitación fue obtenido siguiendo la fluorescencia a la máxima longitud de onda de emisión. Así mismo el espectro de emisión se obtuvo excitando a la correspondiente longitud de onda máxima. 


\section{Espectroscopía UV-Vis}

Las medidas espectrofotométricas UV-Vis se realizaron en un aparato V-630 (Jasco Corporation, Tokio, Japón), unido a un baño termostático Tectron (JP Selecta, Barcelona, España). Para la cuantificación de betalaínas, la concentración de pigmento fue evaluada usando coeficientes de extinción molar de $\varepsilon=46,000 \mathrm{M}^{-1} \cdot \mathrm{cm}^{-1}$ (dopaxantina), $\varepsilon=27,000$ $\mathrm{M}^{-1} \cdot \mathrm{cm}^{-1}$ (ácido betalámico), $\varepsilon=44,000 \mathrm{M}^{-1} \cdot \mathrm{cm}^{-1}$ (triptófano-betaxantina), $\varepsilon=46,000$ $\mathrm{M}^{-1} \cdot \mathrm{cm}^{-1}$ (dopaxantina), $\mathcal{E}=48,000 \mathrm{M}^{-1} \cdot \mathrm{cm}^{-1}$ (glutamina-betaxantina y la dopaminabetaxantina), $\mathcal{E}=65000 \mathrm{M}^{-1} \cdot \mathrm{cm}^{-1}$ (betanina y amarantina) y $\mathcal{E}=54000 \mathrm{M}^{-1} \cdot \mathrm{cm}^{-1}$ (betanidina) (Schwartz y von Elbe, 1980; Trezzini y Zryd, 1991; Gandía-Herrero et al., 2010). Las medidas fueron realizadas en disoluciones acuosas a $25^{\circ} \mathrm{C}$.

\section{Microscopía}

Para la microscopía de campo claro y fluorescencia se utilizó un microscopio Leica DMRB (Leica Microsystems, Wetzlar, Alemania). En el caso de imágenes de fluorescencia, se utilizó el sistema de filtros I3 (Leica Microsystems) que limitó la luz de excitación al rango de 450-490 nm.

\section{Encapsulación de betalaínas y dopamina en cultivos in vitro de C. argentea}

De la línea celular de callo rojo y callo amarillo de celosía, por separado se tomaron 35 g de tejido fresco y se extrajeron en $25 \mathrm{~mL}$ de tampón fosfato $10 \mathrm{mM} \mathrm{pH} 6.0$, en un homogeneizador Polytron (Kinematica AG, Suiza) (5 s, 2 pulsos, a velocidad media). El 
homogeneizado de ambas líneas, fue filtrado a través de tela de nylon y se centrifugo a 120000 g durante 40 min. Al extracto resultante se le adicionó maltodextrina al 10 y $20 \%$ w / v, bajo agitación vigorosa con vórtex. Los extractos fueron sometidos a un secado por pulverización en un mini secador Büchi B-290 (Büchi Labortechnik AG, Flawil, Suiza). La temperatura del aire de entrada fue de $140^{\circ} \mathrm{C}$, y el aire de salida se mantuvo a $75^{\circ} \mathrm{C}$. $\mathrm{La}$ alimentación del líquido fue de 5 mL / min. La automatización del flujo fue de 246 L / h, y el flujo de aire de secado de $36 \mathrm{~m}^{3}$ / h (Gandía- Herrero et al., 2013).

\section{Análisis estadístico}

El análisis de datos se llevó a cabo mediante una prueba paramétrica de análisis de varianza (ANOVA) y una prueba de Tuckey con una $\mathrm{P}<0.05$, con el programa SPSS versión 8.0 (SPSS, Chicago, IL). En cada caso, los errores asociados a los resultados proporcionados se calcularon sobre la base de la desviación estándar residual. 
Capítulo 5.

\section{PRODUCCIÓN DE BETALAÍNAS EN CULTIVOS IN VITRO DE Amaranthus hypochondriacus variedad nutrisol}




\section{TABLA DE CONTENIDO GRÁFICO}

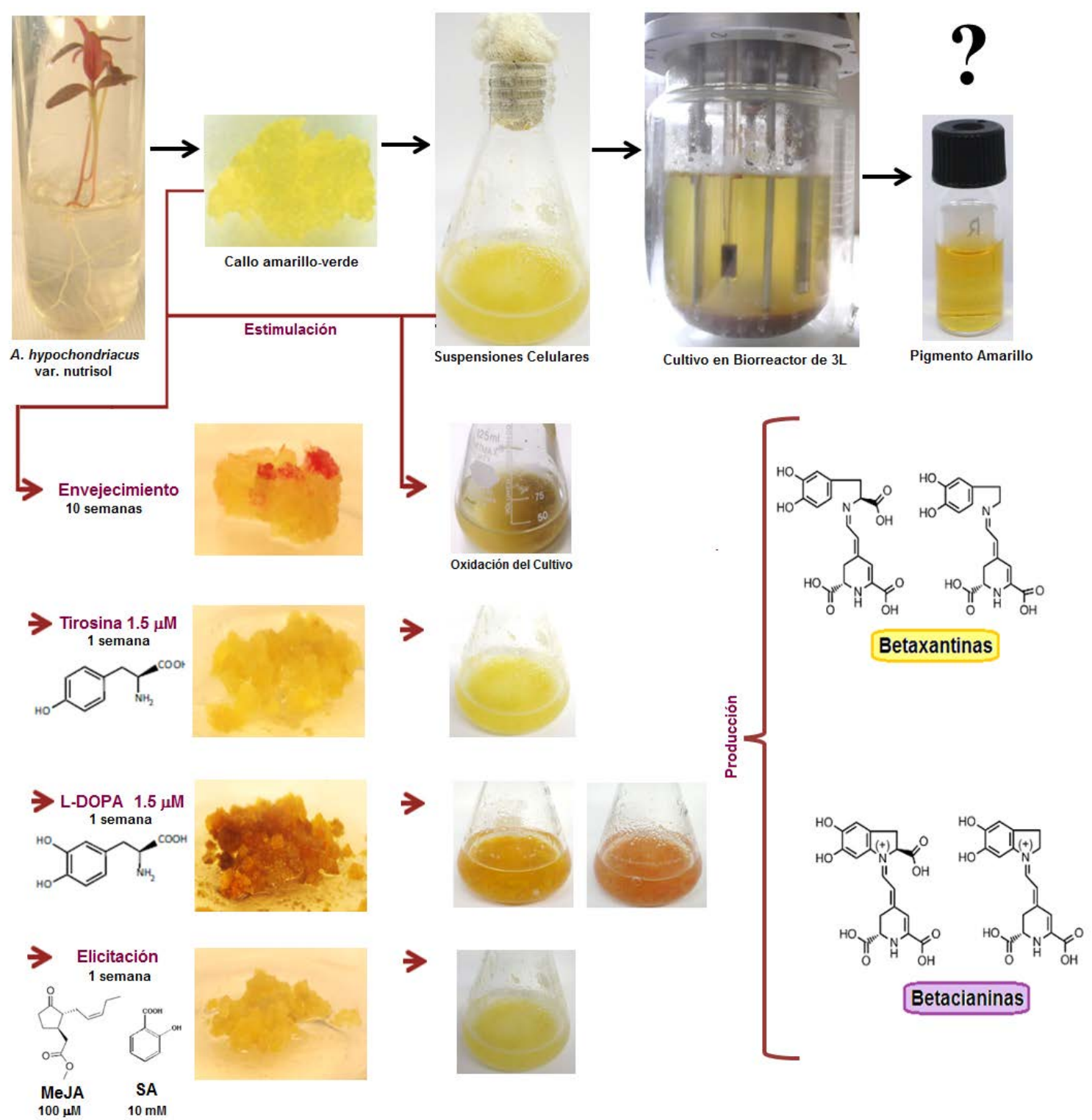

De nuestro conocimiento, este es el primer informe sobre la producción de betalaínas mediante la estimulación con estrés abiótico y biotransformación, en cultivos in vitro en A. hypochondriacus var. nutrisol. El cultivo también produce un pigmento amarillo que no son betaxantinas, del cual se ha realizado parcialmente su caracterización. 


\section{RESUMEN}

Con el objetivo de obtener cultivos celulares de $A$. hypochondriacus productores de betalaínas, se estableció una línea estable de callo color amarillo verdoso, en medio MS con $6.66 \mu \mathrm{M}$ de BAP y $6.79 \mu \mathrm{M}$ de 2,4-D, de la que derivó una línea de células en suspensión a nivel de matraz, la cual se escaló a biorreactor de tanque agitado de 3L. Estos cultivos produjeron un pigmento amarillo fluorescente, diferente a las betaxantinas que no pertenece al grupo de las betaxantinas. Para inducir la síntesis de betalaínas, las líneas de callo y suspensiones en matraz, se sometieron a envejecimiento del cultivo, elicitación con $100 \mu \mathrm{M}$ de metil jasmonato (MeJA) y 10 mM de ácido salicílico (SA), y adición de $1.5 \mathrm{mM}$ de tirosina y L-DOPA. Con estas estrategias, se logró obtener betalaínas, tres de estas dihidroxiladas: dopaxantina carboxilada, miraxantina $\mathrm{V}$ y betanidina. La máxima acumulación de los pigmentos se alcanzó en las líneas en suspensión tratadas con L-DOPA, una semana posterior a la inoculación (18.07 mg/ g de peso seco). Estos cultivos representan un modelo adecuado para el estudio de las vías de activación en la ruta de biosíntesis de betalaínas, y pueden también una fuente viable de pigmentos con potencial aplicación industrial.

Palabras clave: betalaínas, estrés abiótico, precursor, antiradical, bioactivo. 


\section{ABSTRACT}

In order to obtain a cell line from A. hypochondriacus producer of betalains, callus culture were established in MS medium with 6.66 $\mu \mathrm{M}$ BAP and $6.79 \mu \mathrm{M}$ 2,4-D. A stable cell line of callus greenish yellow in color was obtained and used to develop a cell line in suspension, grown in flasks and scaled up in stirred tank bioreactor of 3L. These cultures produced a fluorescent yellow pigment that does not belong to the group of betaxanthins. To induce betalains synthesis, callus and suspensions in flasks, were stimulated with aging of culture, $100 \mu \mathrm{M}$ methyl jasmonate (MeJA) and $10 \mathrm{mM}$ (salicylic acid) SA elicitors, and by addition of $1.5 \mathrm{mM}$ tyrosine and L-DOPA precursors ob betalains biosynthesis. It was possible to obtain betalains, three of these being dihydroxylated: dopaxanthin, miraxanthin $\mathrm{V}$ and betanidin. The maximum accumulation of pigments was reached in suspension cell lines treated with L-DOPA, a week after inoculation (18.07 $\mathrm{mg} / \mathrm{g}$ dry weight). These in vitro cultures could be a suitable model to study the activation ways of betalains biosynthesis pathway and a viable source of pigments with potential industrial application.

Keywords: betalains, abiotic stress, elicitor, precursor, antiradical, bioactive 


\section{HIPÓTESIS}

Amaranthus hypochondriacus variedad nutrisol, sintetiza de manera natural betalaínas, por tanto es posible establecer líneas celulares de la especie productoras de estos pigmentos empleando reguladores del crecimiento vegetal como 2,4-D y BAP.

La adición de precursores de la ruta de biosíntesis como tirosina y L-DOPA, así como los elicitores metiljasmonato (MeJA) y ácido salicílico (SA), promoverá la producción de betalaínas en los cultivos de Amaranthus hypochondriacus variedad nutrisol. 


\section{OBJETIVOS}

\section{OBJETIVO GENERAL}

Establecer cultivos in vitro de Amaranthus hypochondriacus variedad nutrisol, para la obtención y caracterización de betalaínas.

\section{OBJETIVOS ESPECÍFICOS}

A. Establecer cultivos asépticos de Amaranthus hypochondriacus var. nutrisol

B. Evaluar en explantes de hipocótilos y hojas de A. hypochondriacus, el efecto de distintas combinaciones de RCV para la inducción de callo.

C. Establecer una línea celular de A. hypochondriacus en suspensión a nivel de matraz, a partir del tratamiento que presente mayor crecimiento, friabilidad y pigmentación.

D. Establecer una línea celular de Amaranthus hypochondriacus en suspensión a nivel de biorreactor de 3 L, a partir de la línea celular en suspensión. 
E. Evaluar la progresiva síntesis de betalaínas y sus intermediarios, en la línea celular de callo y suspensión de A. hypochodriacus, durante el envejecimiento del cultivo.

F. Evaluar el efecto de la adición de tirosina, L-DOPA, MeJA y SA, sobre la producción de betalaínas, en los cultivos celulares de callo y suspensión de Amaranthus hypochodriacus.

G. Caracterizar y cuantificar las betalaínas presentes en la línea celular de Amaranthus hypochondriacus, producidas durante el envejecimiento del cultivo y al adicionar tirosina, L-DOPA, MeJA y SA. 


\section{RESULTADOS Y DISCUSIÓN}

\section{Establecimiento de cultivo aséptico}

El punto de partida para el cultivo de tejidos vegetales es la iniciación, es decir el establecimiento de la asepsia, donde las semillas o explantes son sometidos a condiciones de desinfección, con el propósito de ser transferidos a un medio de cultivo libre de microorganismos, ya que estos crecen de manera oportunista a una velocidad mucho más rápida que las células vegetales y eventualmente colonizan y matan a los tejidos (Cardoza, 2008). Por tanto, para la limpieza de semillas de A. hypochondriacus, se evaluaron seis tratamientos distintos, demostrándose que la exposición a detergente aniónico líquido al 1 \% durante 15 minutos, $70 \%$ de alcohol durante 30 segundos, hipoclorito de sodio al $1.8 \%$ y $0.2 \%$ de polisorbato-20 por 30 min, promovió la desinfección del $100 \%$ de las semillas sin mostrar contaminación (Tabla 6); estableciéndose este procedimiento como protocolo de lavado.

\section{Obtención de líneas celulares de callo de A. hypochondriacus var. nutrisol.}

Todas las semillas de A. hypochondriacus var. nutrisol, germinaron 8 días después de su siembra; coincidiendo con lo reportado para esta especie, ya que se consideran como condiciones óptimas de germinación temperaturas de 25 a $30^{\circ} \mathrm{C}, 18$ a 30 horas para que brote la radícula y un aproximado de 10 días para el establecimiento de la plántula (Alejandre-Iturbide y Gómez-Lorence, 1986). Durante 20 días y bajo condiciones asépticas, 
las plántulas de A. hypochondricus (Figura 16A) fueron cultivadas, para su uso posterior en los experimentos de inducción de callo. Se realizó un estudio con explantes de hipocótilos y hojas de las plántulas debido a la presencia de coloración roja en el tejido, utilizando distintas concentraciones de 2,4-D y BAP, por separado y en combinación (Tabla 7). En los explantes de hipocótilo, en todos los casos se observó pérdida de color, sin presentar respuesta a callo a los 30 días de cultivo (Figura 15A). Lo anterior difiere a lo reportado en hipocótilos de Beta vulgaris, tratados con bajas cantidades de 2,4-D y cinétina, generán callos rojos (Rodríguez-Monroy et. al. 1994); no obstante las citocininas, pueden reducir la acumulación de betalaínas en los tejidos (Santos-Díaz et al. 2005). Por el contrario, los explantes de hojas registraron alta inducción a callo, la cual se vio afectada por el tipo y concentración de los reguladores del crecimiento vegetal (Tabla 7). Los tratamientos que contenían exclusivamente la auxina 2,4-D formaron callo de coloración verde olivo (Figura 15B). En cuanto al tejido calloso obtenido solamente con la citocinina BAP, en un inicio fue de color blanco amarillento, observándose obscurecimiento en casi la totalidad del tejido a los 15 días de cultivo (Figura 15C). De manera general, los tratamientos con BAP y 2,4-D, desarrollaron callos de color verde, con textura muy compacta al momento de ser subcultivados. Sin embargo el tratamiento con $6.66 \mu \mathrm{M}$ de BAP y $6.79 \mu \mathrm{M}$ de 2,4D, promovió la formación de callo friable color amarillo verdoso y proliferación celular mayor en comparación con los tratamientos anteriores (Figura 15 D), a los 30 días de cultivo; por lo que este tratamiento fue seleccionado para realizar la propagación del cultivo. Lo anterior coincide con lo reportado en la literatura, ya que en líneas celulares de 
Amaranthus tricolor, utilizando distintas concentraciones de auxinas y citocininas (BAP), se obtuvo tejido calloso con diferentes tipos de pigmentación (Biswas et al., 2013).

Tabla 6. Porcentaje de contaminación de las semillas de Amaranthus hypochondriacus, sometidas a seis tratamientos distintos de asepsia

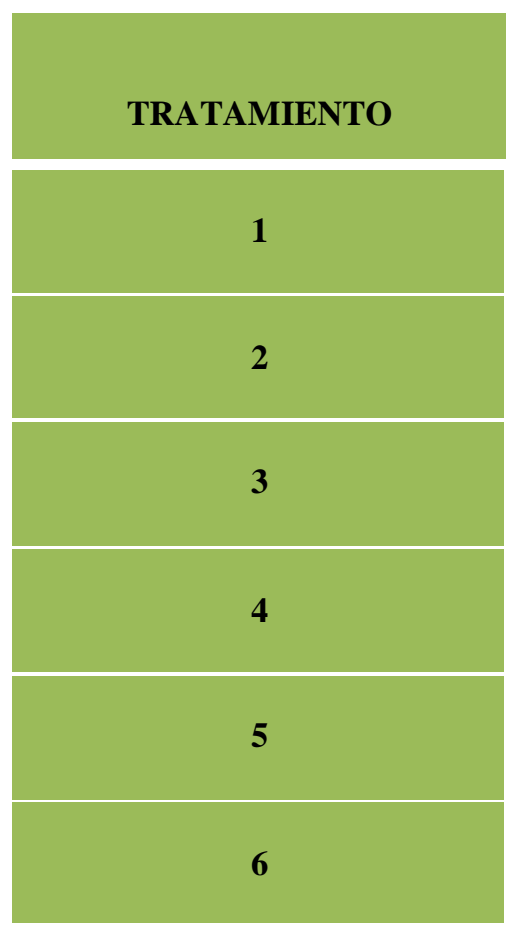

\begin{tabular}{|c|c|}
\hline CARACTERISTICAS & \% CONTAMINACIÓN \\
\hline $\begin{array}{c}70 \% \text { de alcohol } 15 \mathrm{seg} / 0.6 \% \text { de } \\
\text { hipoclorito de sodio } 20 \mathrm{~min}\end{array}$ & $75 \pm 0.25$ \\
\hline $\begin{array}{c}70 \% \text { de alcohol } 30 \mathrm{seg} / 0.6 \% \text { de } \\
\text { hipoclorito de sodio } 30 \mathrm{~min}\end{array}$ & $62 \pm 0.38$ \\
\hline $\begin{array}{l}70 \% \text { de alcohol } 15 \mathrm{seg} / 1.2 \% \text { de } \\
\text { hipoclorito de sodio } 20 \mathrm{~min}\end{array}$ & $48 \pm 0.41$ \\
\hline $\begin{array}{c}70 \% \text { de alcohol } 30 \mathrm{seg} / 1.2 \% \text { de } \\
\text { hipoclorito de sodio } 30 \mathrm{~min}\end{array}$ & $20 \pm 0.33$ \\
\hline $\begin{array}{c}70 \% \text { de alcohol } 15 \mathrm{seg} / 1.8 \% \text { de } \\
\text { hipoclorito de sodio } 20 \mathrm{~min}\end{array}$ & $15 \pm 0.13$ \\
\hline $\begin{array}{c}70 \% \text { de alcohol } 30 \mathrm{seg} / 1.8 \% \text { de } \\
\text { hipoclorito de sodio } 30 \mathrm{~min}\end{array}$ & $0 \pm 0.00$ \\
\hline
\end{tabular}

*Cada tratamiento con lotes de cinco unidades por triplicado
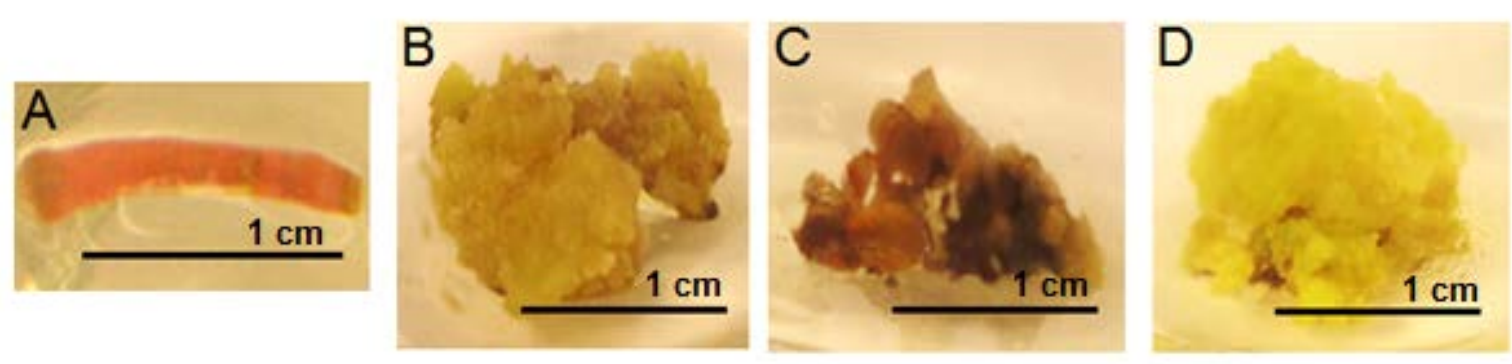

Figura 15: Características fenotípicas del explante de hipocótilo (A) y callos inducidos en explantes de hoja de A. hypochondriacus a los 30 días de cultivo. (B) 2,4-D $6.79 \mu \mathrm{M}$, callo color verde olivo. (C) BAP $6.66 \mu \mathrm{M}$, callo color blanco amarillento, con obscurecimiento en casi la totalidad del tejido. (D) BAP $6.66 \mu \mathrm{M}$ con 2,4-D $6.79 \mu \mathrm{M}$, callo color amarillo verdoso. 
Tabla 7. Efecto de los reguladores de crecimiento vegetal (RCV), sobre la inducción de callos a partir de explantes de hoja de A. hypochondriacus var. nutrisol, después de 30 días de cultivo.

\begin{tabular}{ccc}
\hline \multicolumn{2}{c}{ RCV $(\boldsymbol{\mu M})$} & $\begin{array}{c}\text { Explantes formando } \\
\text { callo }(\%)\end{array}$ \\
\hline BAP & $\mathbf{2 , 4 - D}$ & $100.00 \pm 0.00^{\mathrm{a}}$ \\
\hline 0.00 & 0.00 & $100.00 \pm 0.00^{\mathrm{a}}$ \\
0.00 & 2.26 & $100.00 \pm 0.00^{\mathrm{a}}$ \\
0.00 & 4.52 & $100.00 \pm 0.00^{\mathrm{a}}$ \\
0.00 & 6.79 & $100.00 \pm 0.00^{\mathrm{a}}$ \\
0.00 & 9.05 & $100.00 \pm 0.00^{\mathrm{a}}$ \\
2.22 & 0.00 & $100.00 \pm 0.00^{\mathrm{a}}$ \\
2.22 & 2.26 & $100.00 \pm 0.00^{\mathrm{a}}$ \\
2.22 & 4.52 & $100.00 \pm 0.00^{\mathrm{a}}$ \\
2.22 & 6.79 & $100.00 \pm 0.00^{\mathrm{a}}$ \\
2.22 & 9.05 & $100.00 \pm 0.00^{\mathrm{a}}$ \\
4.44 & 0.00 & $100.00 \pm 0.00^{\mathrm{a}}$ \\
4.44 & 2.26 & $100.00 \pm 0.00^{\mathrm{a}}$ \\
4.44 & 4.52 & $93.30 \pm 19.04^{\mathrm{b}}$ \\
4.44 & 6.79 & $100.00 \pm 0.00^{\mathrm{a}}$ \\
4.44 & 9.05 & $86.66 \pm 23.09^{\mathrm{b}}$ \\
6.66 & 0.00 & $100.00 \pm 0.00^{\mathrm{a}}$ \\
6.66 & 2.26 & $100.00 \pm 0.00^{\mathrm{a}}$ \\
6.66 & 4.52 & $100.00 \pm 0.00^{\mathrm{a}}$ \\
6.66 & 6.79 & $100.00 \pm 0.00^{\mathrm{a}}$ \\
6.66 & 9.05 & $80.00 \pm 10.24^{\mathrm{b}}$ \\
8.88 & 0.00 & $100.00 \pm 0.00^{\mathrm{a}}$ \\
8.88 & 2.26 & $100.00 \pm 0.00^{\mathrm{a}}$ \\
8.88 & 4.52 & $100.00 \pm 0.00^{\mathrm{a}}$ \\
8.88 & 6.79 & $100.00 \pm 0.00^{\mathrm{a}}$ \\
8.88 & 9.05 &
\end{tabular}

Cada valor se deriva de tres tubos independientes por triplicado. Los valores que comparten la misma letra se corresponden con diferencias no significativas según la prueba de Tukey $(\mathrm{P}<0.05)$. 

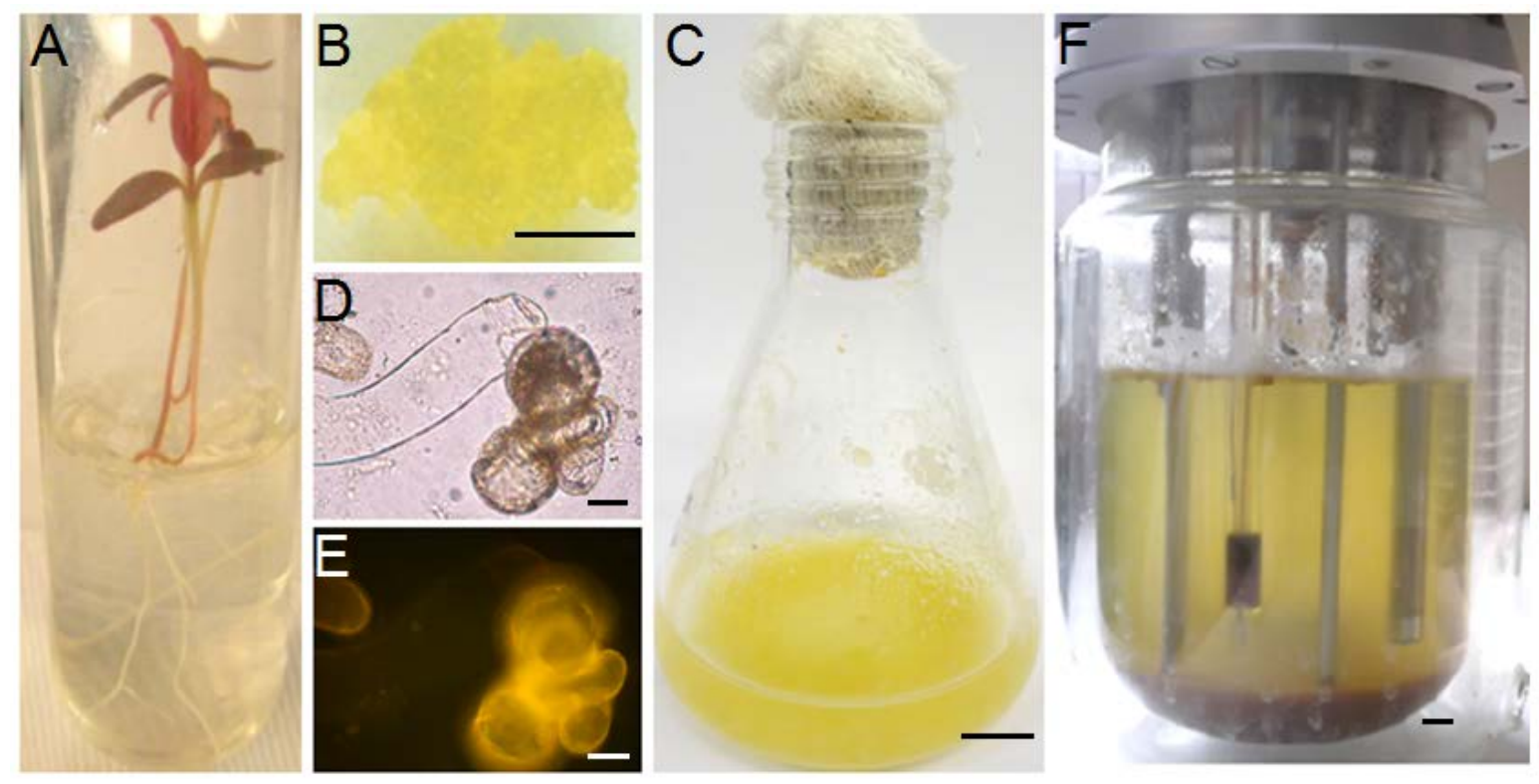

Figura 16. Establecimiento de líneas celulares in vitro derivadas de A. hypochondriacus var. nutrisol. (A) Plántulas de veinte días de edad fueron utilizadas como fuente de explantes. (B) Características fenotípicas de la línea de callo amarillo verdoso. (C) Cultivo de células en suspensión a nivel de matraz, 14 días después de subcultivo. Micrografía de células en suspensión; técnica de campo claro (D), técnica de fluorescencia (E); sólo las porciones amarillas de la imagen de campo claro, que contienen pigmento amarillo, presentan emisión de luz en el perfil de fluorescencia. (F) Cultivo de células en suspensión a nivel de biorreactor de 3L, a los 14 días de cultivo. Barra en B, C y F equivale a $1 \mathrm{~cm}$; en D 5 a $10 \mu \mathrm{m}$.

\section{Cultivos en suspensión a nivel de matraz y biorreactor de $3 \mathrm{~L}$}

La línea celular de callo de color amarillo verdoso, se utilizó para iniciar suspensiones celulares de A. hypochondriacus (Figura 16C). El cultivo líquido fue establecido con éxito en medio MS suplementado con 30 g / L sacarosa, 6. $66 \mu$ M BAP y $6.79 \mu \mathrm{M}$ 2,4-D. El cultivo de suspensiones en matraz se escaló a biorreactor de tanque agitado con capacidad 
de 3 L, conteniendo 1.2 L de células en suspensión (Figura 16F), utilizando el mismo medio y condiciones de incubación.

La evaluación del crecimiento celular del cultivo en suspensión resulta fundamental para caracterizar el tiempo de mayor producción de biomasa, ya que en muchas ocasiones esto conlleva la obtención de altas cantidades de los compuestos de interés (Cardosa, 2008). La cinética de crecimiento celular (Figura 17A), indica una fase lag de 3 días, en los que la biomasa alcanzó $4.78 \pm 0.77$ g peso seco / L en matraz, y $5.88 \pm 0.79$ g peso seco / L en biorreactor. Después de este tiempo, las células entraron en fase de crecimiento exponencial. El crecimiento se prolongó hasta el día 12, con un máximo de acumulación de biomasa de 13,09 \pm 0.88 y $13.95 \pm 0.74$ g peso seco / L; un tiempo de duplicación de 5.20 y 4.92 días; una tasa de crecimiento $(\mu)$ de $0.133 /$ día $^{-1}$ y $0.140 /$ día $^{-1}$; y viabilidad celular de $75.40 \%$ y $85.53 \%$ (Figura 17B y 18C), en cultivos en matraz y biorreactor respectivamente. En ambos sistemas el $\mathrm{pH}$ fue supervisado, durante toda la cinética (resultados no mostrados), sin presentar variación significativa, obteniéndose un valor medio de 4.86. Esto demuestra que los cultivos celulares de A. hypochondricus en matraces agitados, bajo las condiciones descritas, se establecieron de manera favorable, alcanzando un rendimiento en biomasa correspondiente a valores usualmente reportados en la literatura, para otros cultivos vegetales en condiciones semejantes (Rao y Ravishankar, 2002). Sin embargo al comparar el sistema de cultivo en matraz y en reactor, se observa que la velocidad de crecimiento celular, la viabilidad celular y la acumulación de biomasa celular, presentan una ligera tendencia a ser mayores en los cultivos de biorreactor; esta 
aparente ventaja puede corresponder a que el cultivo en tanque agitado favorece el incremento de la transferencia de oxígeno y el mezclado de nutrientes, debido al patrón de flujo radial que resulta del uso de la turbina Rushton; como se observó en las células de Beta vulgaris, cultivadas bajo condiciones similares (Jiménez-Aparicio et al., 1999; Rodríguez Monroy et al., 1999); corroborándose que el crecimiento y viabilidad celular depende de las condiciones del sistema donde se cultivan las células vegetales (Cardosa, 2008).

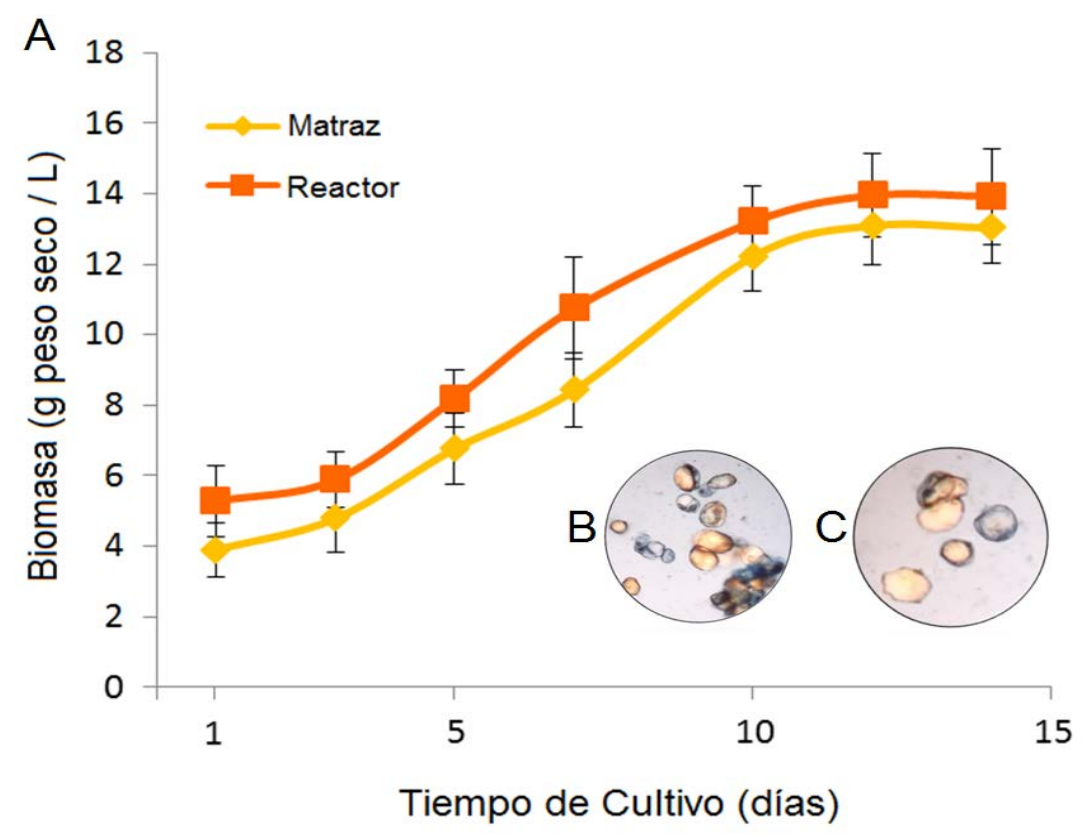

Figura 17. Curva de crecimiento para el cultivo de A. hipochondriacus, en suspensión a nivel de matraz y biorreactor de 3L, obtenido en medio líquido MS suplementado con $30 \mathrm{~g} / \mathrm{L}$ de sacarosa, $6.66 \mu \mathrm{M}$ de BAP y $6.79 \mu \mathrm{M}$ 2,4-D. (A) Evolución temporal del crecimiento. Micrografía en campo claro de células cultivadas en matraz (B) y reactor (C); se muestra la viabilidad celular determinada a los 8 días por la prueba de tinción con azul de Evans, mediante el conteo de las células que no se colorearon (células viables). 
La morfología de las células crecidas en matraz y biorreactor, en general fue redondeada, aunque también se visualizaron células con forma alargada, con tendencia a formar agregados (Figura 17B y 18C); probablemente en relación con las propiedades de cohesión de la pared celular y el estrés hidrodinámico (Trejo-Tapia y Rodríguez-Monroy, 2007). Mediante microscopía de campo claro, se observó que bajo estos sistemas de cultivo, la pigmentación de las células fue de color amarillo ámbar (Figura 16D). Por microscopía de fluorescencia, pudo observarse que sólo las porciones de las células que contienen el pigmento amarillo presentan emisión de luz en el perfil de fluorescencia (Figura 16E). Esta propiedad está descrita para las betaxantinas (Gandía-Herrero et al., 2005b), por lo que se procedió a realizar la caracterización del pigmento para conocer su naturaleza química y corroborar si la coloración amarilla de las células se debía a este tipo particular de betalaínas.

\section{Caracterización parcial del pigmento amarillo}

Para extraer y caracterizar el pigmento amarillo presente en las líneas celulares de callo y de suspensiones en matraz y biorreactor, se utilizó el protocolo específico para la determinación de betaxantinas, publicado por Gandía-Herrero et al., en 2005b. Sin embargo con el tampón fosfato10 mM (pH 6.0) y ácido ascórbico 10 mM, no fue posible obtener el pigmento; por lo que la extracción se realizó con metanol, un disolvente con menor polaridad, obteniendo un extracto amarillo de las líneas celulares de $A$. hypochondricus. Al analizar el extracto metanólico por HPLC (Gandía-Herrero et al., 
2005b), se observaron dos picos mayoritarios con tiempos de retención de 24.95 y 27.26 minutos (Figura 18), y con longitudes de absorbancia máxima ( $\lambda$ ) de 418 y 413 nm, respectivamente. Estos datos fueron diferentes a lo establecido para las betaxantinas con tiempos de retención menores a los 21 minutos y $\lambda=480 \mathrm{~nm}$, bajo las mismas condiciones de operación y análisis (Gandía-Herrero et al., 2005b). El análisis de fluorescencia detectó un espectro de excitación máxima de 380 nm y un espectro de emisión máxima de 560 nm (Figura 19), los cuales también difieren de los reportados para las betaxantinas, con máximos de excitación comprendidos entre 463 y 475 nm y máximos de emisión comprendidos entre 506 y 515 nm (Gandía-Herrero et al., 2005b). Todos estos análisis evidencian que el pigmento amarillo de las líneas in vitro de A. hypochondricus, no corresponde al grupo de betalaínas.

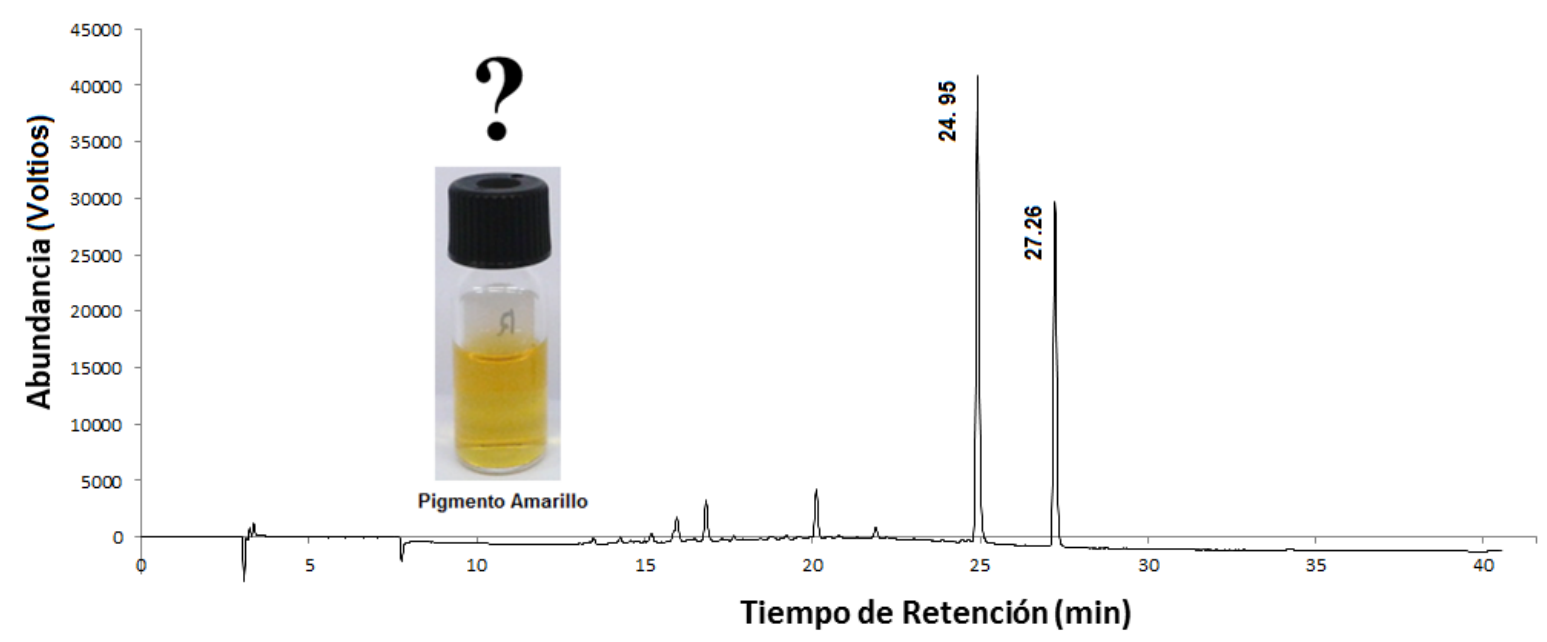

Figura 18. Perfil cromatográfico del pigmento amarillo obtenido de los cultivos in vitro de $A$. hypochondriacus var. nutrisol. Los perfiles de HPLC a $420 \mathrm{~nm}$, son representativos para el pigmento amarillo obtenido de las muestras de la línea celular de callo, suspensión a nivel de matraz y biorreactor a los 12 días de cultivo. 

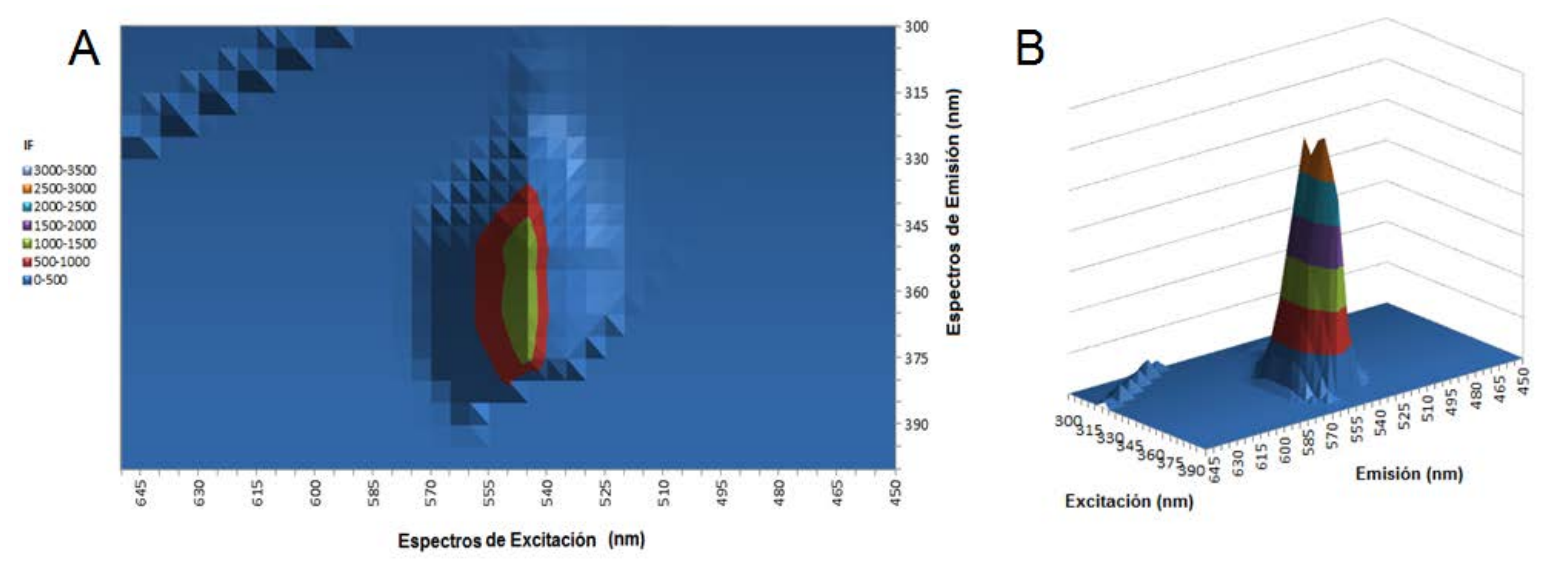

Figura 19: Espectros de fluorescencia de emisión y excitación del pigmento amarillo presente en las líneas celulares in vitro de A. hypochondriacus. Gráfico 3D de contorno (A) y de montaña (B). Los espectros se obtuvieron en metanol a $4{ }^{\circ} \mathrm{C}$.

Con el propósito de dilucidar la naturaleza química del pigmento amarillo se procedió a puricarlo por HPLC, obteniéndose dos fracciones. Cada fracción fue analizada por HPLCESI-MS. Los valores de masa determinados para la primera fracción ( $T_{r} 24.95$ min), corresponde a un ion molecular de $m$ / z 219.0721, y para la segunda fracción $\left(T_{r} 27.26\right.$ min) corresponde a un ion molecular de $m$ / z 233.0902 (Figura 20). Estudios parciales por Resonancia Magnética Nuclear (RMN) (datos no mostrados), presentan la posibilidad de que los pigmentos amarillos purificados, puedan corresponder a derivados del ácido ferúlico. 

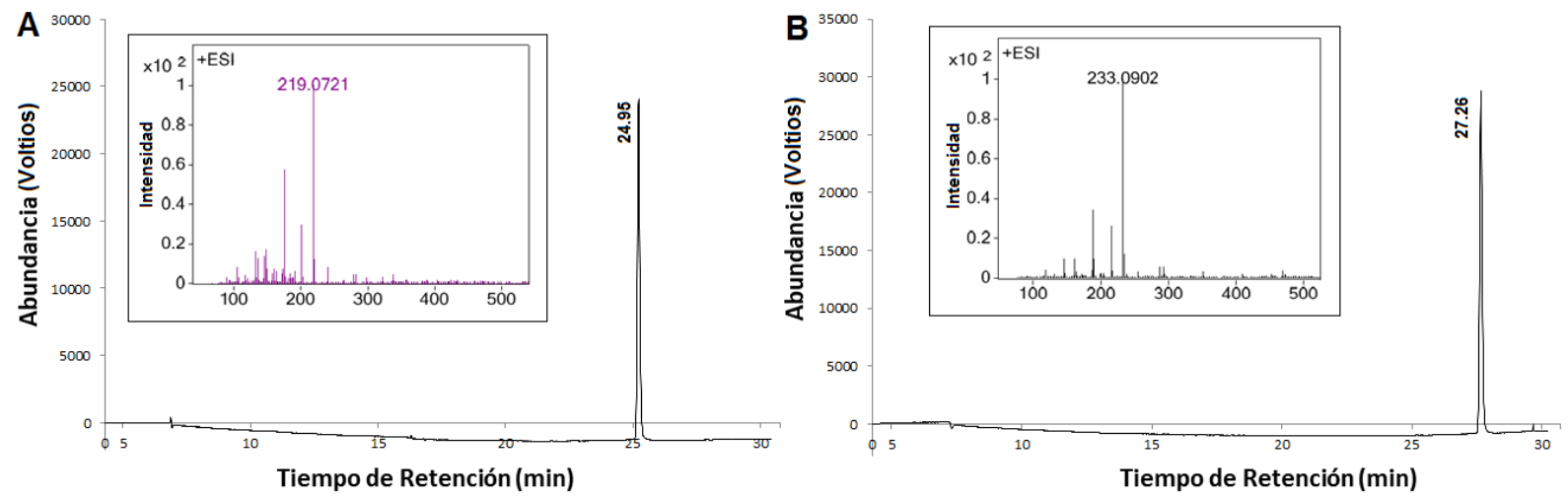

Figura 20: Perfiles cromatográficos y espectros de masas de las fracciones purificadas por HPLC, del pigmento amarillo obtenido de los cultivos in vitro de A. hypochondriacus. (A) Fracción 1 con tiempo de retención $\left(T_{r}\right)$ de 24.95 minutos y $\mathrm{m} / \mathrm{z}$ 219.0721. (B) Fracción 2 con $T_{r}$ de 27.26 y $\mathrm{m} / \mathrm{z}$ 233.0902. Los perfiles de HPLC a $420 \mathrm{~nm}$ y los ESI-MS, son representativos para el pigmento amarillo obtenido de las muestras de la línea celular de callo, suspensión a nivel de matraz y biorreactor a los 12 días de cultivo.

\section{Inducción de la biosíntesis de betalaínas en líneas in vitro de $A$. hypochondriacus}

Habiéndose corroborado la ausencia de betalaínas en los cultivos celulares de $A$. hypochondricus, obtenidos en medio MS con $6.66 \mu \mathrm{M}$ de BAP y $6.79 \mu \mathrm{M}$ de 2,4-D, se procedió a estimular la síntesis de estos metabolitos secundarios, en la línea de callo y de suspensiones celulares a nivel de matraz, mediante estrés abiótico (envejecimiento del cultivo y elicitores: metiljasmonato y ácido salicílico) y la adición de precursores (tirosina y L-DOPA). En el caso de los estudios de elicitación y aplicación de precursores, se realizaron ensayos preliminares partiendo de las concentraciones comúnmente reportadas en la literatura. Para los sustratos tirosina y L-DOPA se ensayaron 1.0, 1.5, 2.0 y 2,5 mM; 
para metiljasmonato (MeJA) 50, 100 y $150 \mu \mathrm{M}$; y para ácido salicílico (SA) 5, 10 y 15 mM. La mayor respuesta de síntesis de pigmento se reportó con $1.5 \mathrm{mM}$ de tirosina y LDOPA, $100 \mu \mathrm{M}$ de MeJA y $10 \mathrm{mM}$ de SA; por lo que dichas concentraciones fueron utilizadas para el análisis de inducción de betalaínas.

\section{A. Envejecimiento del cultivo}

Las plantas acumulan metabolitos secundarios como respuesta a factores ambientales desfavorables (Radman et al., 2003; Baenas et al., 2014). Por tanto, para estimular la síntesis de betalaínas, a la línea celular de callo y a la línea celular de suspensión en matraz, se sometieron a un proceso de envejecimiento del cultivo, hasta completar once semanas sin subcultivar a medio fresco. La línea en suspensión celular presentó coloración café y viabilidad celular del $15 \%$ a las ocho semanas de cultivo sin mostrar la presencia de pigmentos (datos no presentados). En cambio la línea celular de callo a las seis semanas de cultivo, exhibió pequeños fragmentos de pigmentación roja en la superficie del tejido, la cual aumentó progresivamente observándose la máxima coloración a las diez semanas de cultivo (Figura 21B). Mediante el análisis por HPLC-DAD y ESI-MS, se corroboró que dicha pigmentación se correspondía a las betalaínas (Figura 21A), con una producción total máxima de $7.84 \mathrm{mg} / \mathrm{g}$ peso seco, presentándose mayoritariamente betanina (7) con 5.76 mg/ g de peso seco, así como betanidina (3), isobetanina, amarantina (8), isoamarantina, vulgaxantina I (5) y ácido betalámico (10) (Tabla 8). La aparición paulatina de betalaínas durante el envejecimiento del cultivo, puede deberse a la respuesta de las células al estrés por la reducción de nutrientes. Sin embargo al disminuir la concentración del medio MS al 
85, 75, 50, 30 y $15 \%$, las células no presentaron cambios en su coloración (datos no mostrados). Por lo que la inducción de betalaínas en este caso puede deberse, no sólo al descenso de nutrimentos, sino también a cambios particulares en la señalización celular que ocurren por factores ligados a la senescencia y envejecimiento. En las células vegetales el metabolismo secundario se ve favorecido por envejecimiento, en particular para la reducción de las especies reactivas de oxígeno y conservar la homeostasis celular (Sepúlveda-Jiménez et al, 2004; Hadacek et al., 2011).

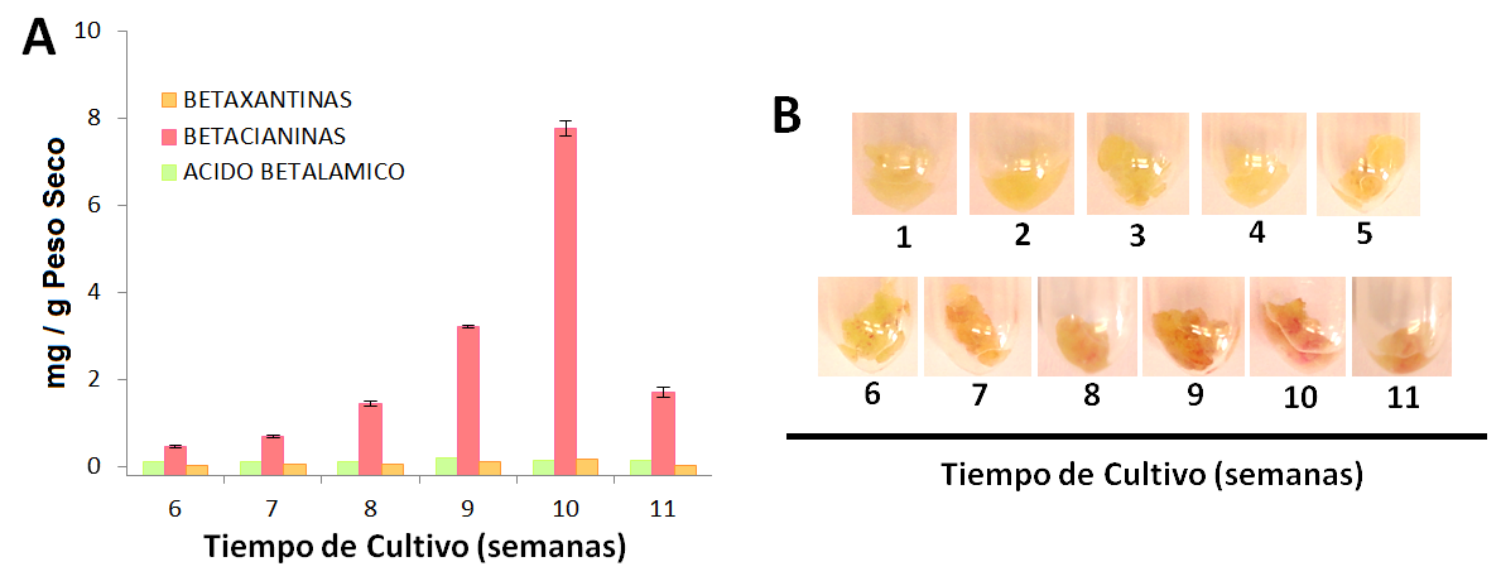

Figura 21. Producción de ácido betalámico y betalaínas en la línea celular de callo de Amaranthus hypochondriacus variedad nutrisol. Evolución temporal de la biosíntesis de compuestos (A) y características fenotípicas del tejido calloso (B) durante el envejecimiento del cultivo. Las barras representan el error estándar de la media de tres mediciones independientes. 
Tabla 8. Producción de betalaínas y ácido betalámico en células de la línea de callo de Amaranthus hypochondriacus, sometida a estrés abiótico por envejecimiento del cultivo.

\begin{tabular}{|c|c|c|c|c|c|c|c|}
\hline \multirow[b]{2}{*}{ COMPUESTO } & \multirow[b]{2}{*}{$\begin{array}{c}T_{r} \\
(\min )\end{array}$} & \multirow[b]{2}{*}{$\begin{array}{c}\text { ESI-MS } \\
(m / z)\end{array}$} & \multirow[b]{2}{*}{$\begin{array}{l}\lambda_{\max } \\
(\mathrm{nm})\end{array}$} & \multirow[b]{2}{*}{$\begin{array}{c}\mathrm{Infl}^{\mathrm{a}} \\
\text { (mg/g } \\
\text { de peso seco) }\end{array}$} & \multirow[b]{2}{*}{$\begin{array}{c}\mathrm{Hip}^{\mathrm{b}} \\
\text { (mg/g } \\
\text { de peso seco) }\end{array}$} & \multirow{2}{*}{$\underset{\substack{\text { Hoja } \\
(\mathrm{mg} / \mathrm{g} \\
\text { de peso seco) }}}{1}$} & \multirow{2}{*}{ 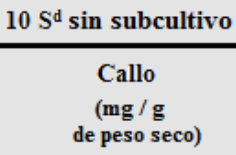 } \\
\hline & & & & & & & \\
\hline dopaxantina (1) & 11.27 & 391 & 472 & $\mathrm{nd}^{c}$ & nd & nd & nd \\
\hline miraxantina V (2) & 12.54 & 347 & 460 & nd & nd & nd & nd \\
\hline betanidina ( 3 ) & 11.76 & 389 & 542 & nd & nd & nd & $0.10 \pm 0.01$ \\
\hline vulgaxantina I (5) & 8.45 & 340 & 472 & nd & nd & nd & $0.11 \pm 0.01$ \\
\hline triptófano-bx (6) & 10.09 & 398 & 472 & nd & nd & nd & nd \\
\hline betanina (7) & 10.25 & 551 & 535 & nd & nd & nd & $5.76 \pm 0.35$ \\
\hline iso-betanina & 16.67 & 551 & 535 & nd & nd & nd & $1.06 \pm 0.07$ \\
\hline amarantina (8) & 9.48 & 727 & 535 & $20.25 \pm 0.39$ & $9 \quad 1.65 \pm 0.02$ & $1.87 \pm 0.03$ & $0.81 \pm 0.05$ \\
\hline iso-amarantina & 9.81 & 727 & 535 & $6.48 \pm 0.20$ & $0.58 \pm 0.01$ & $0.73 \pm 0.05$ & $0.05 \pm 0.01$ \\
\hline ácido betalámico (10) & 12.05 & 211 & 405 & nd & nd & nd & $0.13 \pm 0.01$ \\
\hline
\end{tabular}

${ }^{\mathrm{a}}$ Inflorescencia e ${ }^{\mathrm{b}}$ Hipocótilos de la planta. ${ }^{\mathrm{c}} \mathrm{ND}$ : no detectado. ${ }^{\mathrm{d}} \mathrm{S}$ : semanas. Se muestran los tiempos de retención $\left(T_{r}\right)$ de HPLC, iones moleculares determinados por ESI-MS, longitudes de onda máximas establecidas por DAD y las concentración más altas de betalaínas obtenida en los cultivos a las 10 semanas sin subcultivo. Los pigmentos analizados en inflorescencia, hipocótilos y hojas de la planta se muestran para comparación.

\section{B. Adición de elicitores}

Un elicitor es una sustancia de diverso origen estructural que puede inducir mecanismos de defensa que en ocasiones incrementan la síntesis de metabolitos secundarios específicos (Radman et al., 2003; Baenas et al., 2014). Por lo que, para estimular la acumulación de betalaínas, en la línea celular de callo y suspensión en matraz, se añadió al medio de cultivo de forma individual $100 \mu \mathrm{M}$ de MeJA y 10 mM de SA. Por el análisis de HPLC-DAD y 
ESI-MS, en ambos sistemas de elicitación se detectaron betalaínas. La mayor cantidad de pigmentos, se produjo en las células tratadas con MeJA (0.50 mg/g de peso seco), en relación con SA (0.06 mg/g de peso seco), a las 62 y 38 horas posteriores a la inoculación, respectivamente. Con ambos elicitores, las más altas concentraciones de betalaínas se encontraron en las células en suspensión (Figura 22B y 23D). Las células de callo y suspensión, mostraron una coloración ligeramente amarilla (Figura 23), probablemente debido a la presencia exclusiva de vulgaxantina I (5) y ácido betalámico (10), a excepción de las células en suspensión tratadas con MeJA, en las cuales también se detectó de forma mayoritaria miraxantina $\mathrm{V}$ (2) con $2.06 \mathrm{mg} / \mathrm{g}$ de peso seco, además de triptófano betaxantina (6) y dopa betaxantina (1), a las 62 horas posteriores a la inoculación (Tabla 9). También en este cultivo en suspensión se observó la presencia de betanina (7), con la acumulación más alta $0.238 \mathrm{mg} / \mathrm{g}$ de peso seco a las 72 horas después de añadir MeJA (Figura 22B). Los resultados anteriores corroboran que ambos elicitores poseen la capacidad de estimular la síntesis de betalaínas de manera similar a lo observado en cultivos in vitro de distintas plantas, donde han promovido la producción de antocianinas, carotenoides o fenoles, entre otros compuestos (Mihai et al., 2010; Silva da Rocha et al., 2013; Miao et al., 2014). MeJa y SA activan la vía de la MAP kinasa MPK4, la cual es necesaria para la inducción de los genes defensina (PDF1.2) y tionina (THI2.1), que a su vez inciden en la activación de diferentes rutas del metabolismo secundario en plantas (Petersen et al., 2000). 

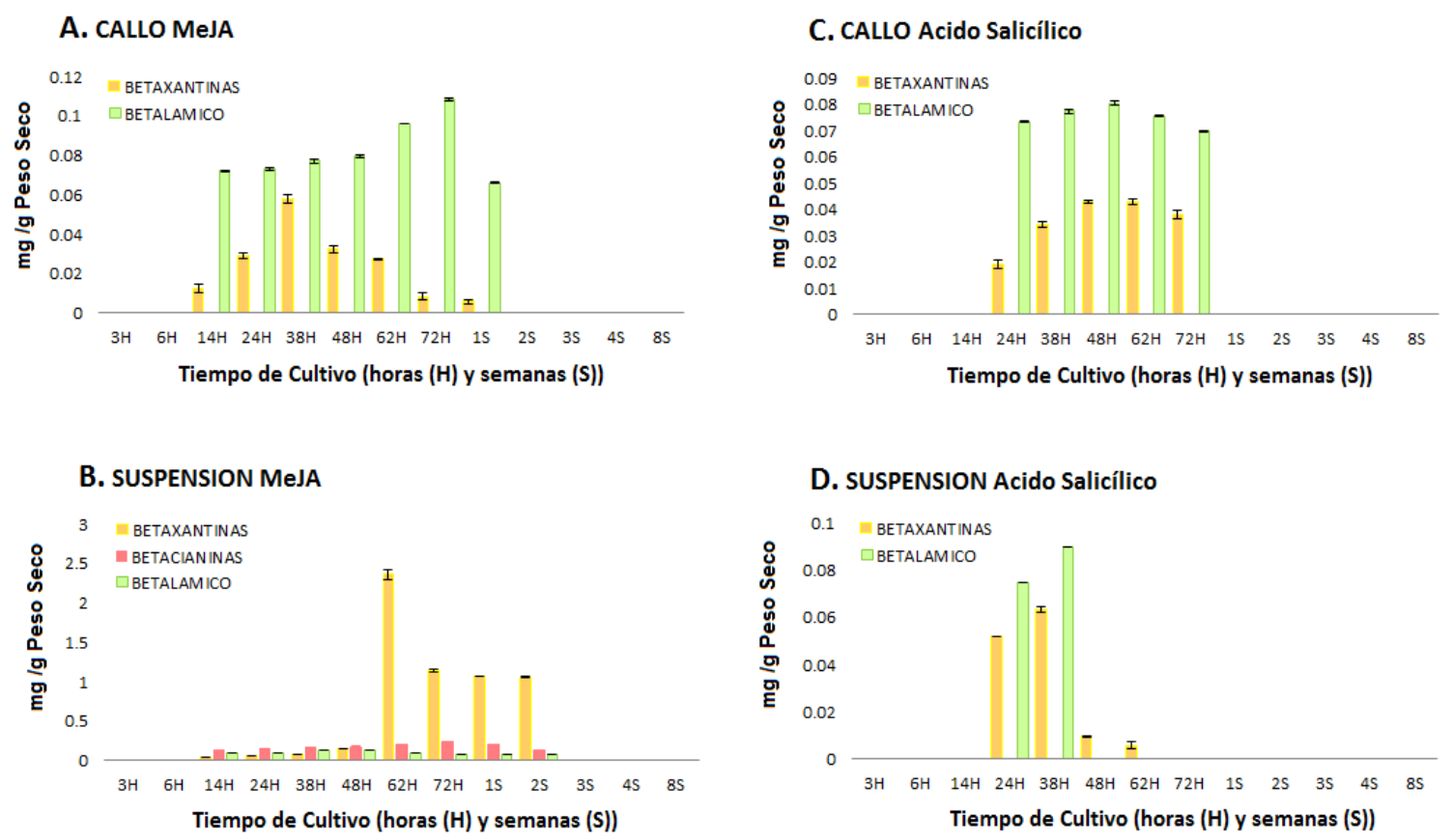

Figura 22. Producción de ácido betalámico y betalaínas en la línea celular de callo y suspensión de Amaranthus hypochondriacus variedad nutrisol, al adicionar $100 \mu \mathrm{M}$ de MeJA y $10 \mathrm{mM}$ de ácido salicílico. Las barras representan el error estándar de la media de tres mediciones independientes.

MeJA

A

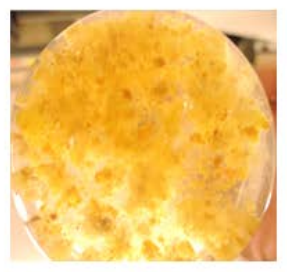

62

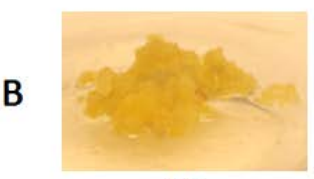

38

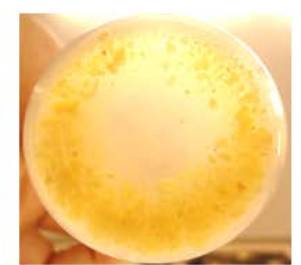

72

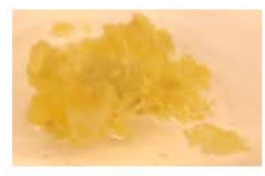

48

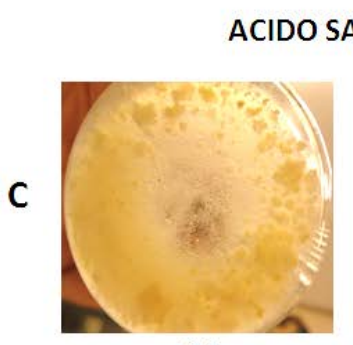

24

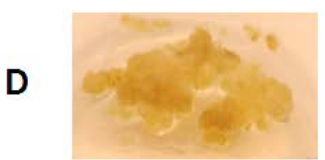

48

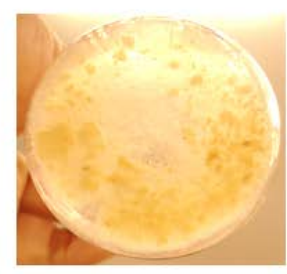

48

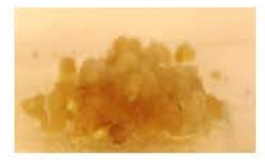

62

Tiempo de Cultivo (horas $(\mathrm{H})$ )

Tiempo de Cultivo (horas $(\mathrm{H}))$

Figura 23. Evolución temporal de las características fenótipicas del cultivo en suspensión (A y C) y de callo (B y D) de Amaranthus hypochondriacus variedad nutrisol, al adicionar $100 \mu \mathrm{M}$ de MeJA y $10 \mathrm{mM}$ de SA. 
Tabla 9. Producción de betalaínas y ácido betalámico en células de la línea de callo y en cultivos en suspensión de Amaranthus hypochondriacus, sometidas a estrés abiótico por elicitación con 100 $\mu \mathrm{M}$ de MeJA y $10 \mathrm{mM}$ de SA.

\begin{tabular}{|c|c|c|c|c|c|c|c|}
\hline \multirow[b]{3}{*}{ COMPUESTO } & \multirow[b]{3}{*}{$\begin{array}{c}T_{r} \\
(\min )\end{array}$} & \multirow[b]{3}{*}{$\begin{array}{l}\text { ESI-MS } \\
\qquad(m / z)\end{array}$} & \multirow[b]{3}{*}{$\begin{array}{l}\lambda_{\max } \\
(\mathrm{nm})\end{array}$} & \multirow{2}{*}{\multicolumn{2}{|c|}{$\frac{\text { MeJA }}{\text { Tiempo de cultivo }}$}} & \multirow{2}{*}{\multicolumn{2}{|c|}{$\frac{\text { SA }}{\text { Tiempo de cultivo }}$}} \\
\hline & & & & & & & \\
\hline & & & & $\begin{array}{c}38 \mathrm{~h}^{\mathrm{a}} \\
\text { Callo } \\
(\mathrm{mg} / \mathrm{g} \\
\text { de peso seco) }\end{array}$ & $\begin{array}{c}62 \mathrm{~h}^{\mathrm{a}} \\
\text { Suspensión } \\
(\mathrm{mg} / \mathrm{g} \\
\text { de peso seco) }\end{array}$ & $\begin{array}{c}\frac{62 \mathrm{~h}^{\mathbf{a}}}{\text { Callo }} \\
(\mathrm{mg} / \mathrm{g} \\
\text { de peso seco) }\end{array}$ & $\begin{array}{c}38 \mathrm{~h}^{\mathrm{a}} \\
\text { Suspensión } \\
(\mathrm{mg} / \mathrm{g} \\
\text { de peso seco) }\end{array}$ \\
\hline dopaxantina (1) & 11.27 & 391 & 472 & $n d^{b}$ & $0.13 \pm 0.01$ & nd & nd \\
\hline miraxantina V (2) & 12.54 & 347 & 460 & nd & $2.06 \pm 0.06$ & nd & nd \\
\hline betanidina (3) & 11.76 & 389 & 542 & nd & nd & nd & nd \\
\hline vulgaxantina I (5) & 8.45 & 340 & 472 & $0.06 \pm 0.01$ & $0.14 \pm 0.01$ & $0.04 \pm 0.01$ & $0.06 \pm 0.01$ \\
\hline triptófano-bx (6) & 10.09 & 398 & 472 & nd & $0.03 \pm 0.01$ & nd & nd \\
\hline betanina (7) & 10.25 & 551 & 535 & nd & $0.20 \pm 0.01$ & nd & nd \\
\hline iso-betanina & 16.67 & 551 & 535 & nd & nd & nd & nd \\
\hline amarantina (8) & 9.48 & 727 & 535 & nd & nd & nd & nd \\
\hline iso-amarantina & 9.81 & 727 & 535 & nd & nd & nd & nd \\
\hline ácido betalámico (10) & 12.05 & 211 & 405 & $0.08 \pm 0.01$ & $0.08 \pm 0.01$ & $0.08 \pm 0.01$ & $0.09 \pm 0.01$ \\
\hline
\end{tabular}

${ }^{a}$ h: horas. ${ }^{b}$ ND: no detectado. Se muestran los tiempos de retención $\left(T_{r}\right)$ de HPLC, iones moleculares determinados por ESI-MS, longitudes de onda máximas establecidas por DAD y las concentraciones más altas de betalaínas obtenidas en los cultivos a las 38 y 62 horas posteriores a la elicitación. 


\section{Adición de precursores}

Un precursor es una molécula que interviene en la ruta biosintética de un metabolito, pudiendo agregarse al medio de cultivo para incrementar el rendimiento del proceso (Radman et al., 2003; Baenas et al., 2014). Por tanto se añadió 1.5 mM de tirosina y LDOPA, de manera individual al medio de la línea celular de callo y de suspensión en matraz, para provocar la biotransformación por las células y la producción de pigmentos. Por el análisis de HPLC-DAD y ESI-MS, se observó que ambos precursores favorecen la biosíntesis de betalaínas, determinándose en general la máxima producción de estos metabolitos una semana posterior a la inoculación (Figura 24). Las betalaínas detectadas en los cultivos fueron betanidina (3), betanina (7), amarantina (8), vulgaxantina I (5), triptófano betaxantina (6), dopa-betaxantina (1) y miraxantina V (2), así como ácido betalámico (10) (Tabla 10). Las concentraciones más elevadas de betalaínas totales se alcanzaron una semana posterior a la inoculación con L-DOPA en las suspensiones celulares, reportándose $18.07 \mathrm{mg} / \mathrm{g}$ de peso seco, correspondiendo $5.18 \mathrm{mg} / \mathrm{g}$ de peso seco a betanina (7), $4.90 \mathrm{mg} / \mathrm{g}$ de peso seco a miraxantina $\mathrm{V}$ (2) y $4.30 \mathrm{mg} / \mathrm{g}$ de peso seco a vulgaxantina I (5) (Tabla 10 y Figura 24D). La presencia mayoritaria de estos pigmentos, explica la coloración amarilla y roja observada en las células tratadas con L-DOPA (Figura 26). En cambio, los cultivos in vitro tratados con tirosina, produjeron menor cantidad de betalaínas totales $1.99 \mathrm{mg} / \mathrm{g}$ de peso seco, a las 72 horas de cultivo, correspondiendo 1.74 mg/g de peso seco a miraxantina V (2), $0.06 \mathrm{mg} / \mathrm{g}$ de peso seco a vulgaxantina I (5) y 0.02 
mg/g de peso seco a triptófano-betaxantina (Tabla 10). La presencia de estas betaxantinas, explica la pigmentación amarilla de las células de callo y suspensiones en matraz, tratadas con tirosina (Figura 25). También se detectó betanina en las células de callo con 0.96 mg/ g de peso seco, y en las células en suspensión con $0.50 \mathrm{mg} / \mathrm{g}$ de peso seco, una y tres semanas posteriores a la inoculación de tirosina respectivamente (Figura 24A y 25B); sin hacerse evidente la presencia de esta betacianina en la coloración de los cultivos. De esta manera se corrobora que la activación e incremento de la ruta biosintética puede lograrse insertando sustratos de las enzimas de la vía, ocasionando la producción del metabolito de interés (Radman et al., 2003; Baenas et al., 2014). La adición de tirosina al sistema estimula la actividad monofenolasa de la enzima citosólica tirosinasa o polifenoloxidasa, la cual hidroxila a dicho sustrato y lo transforma en L-DOPA (Figura 27: reacción 6). El sustrato L-DOPA, formado a partir de tirosina o añadido al sistema, es sustrato de la enzima 4,5-DOPA extradiol-dioxigenasa, que cataliza la ruptura del anillo de L-DOPA para formar al intermedio 4,5-seco-DOPA (Figura 27, reacción 7). A partir de 4,5-seco-DOPA, se forma el ácido betalámico, precursor de todas la betalaínas (Figura 27, reacción 8). El ácido betalámico, puede dirigirse al interior de la vacuola y condensarse con aminas y aminoácidos, formando betaxantinas (Figura 27, reacción 10); o bien condensarse en el citosol con ciclo-DOPA, compuesto derivado de la acción enzimática de la tirosinasa o de la citocromo P450 sobre L-DOPA, y formar betacianinas como betanidina (Figura 27, reacciones 7-9 y 11), que es el intermedio clave de la formación en la vacuola de betacianinas glucosiladas como betanina (Figura 27, reacciones 12-13) y amarantina (Gandía Herrero y García Carmona, 2013). 
Tabla 10. Producción de betalaínas y ácido betalámico en células de la línea de callo y en cultivos en suspensión de Amaranthus hypochondriacus, al añadir $1.5 \mathrm{mM}$ de tirosina y LDOPA.

\begin{tabular}{|c|c|c|c|c|c|c|c|}
\hline \multirow[b]{3}{*}{ COMPUESTO } & \multirow[b]{3}{*}{$\begin{array}{c}T_{r} \\
(\min )\end{array}$} & \multirow[b]{3}{*}{$\begin{array}{l}\text { ESI-MS } \\
\qquad(m / z)\end{array}$} & \multirow[b]{3}{*}{$\begin{array}{l}\lambda_{\max } \\
(\mathrm{nm})\end{array}$} & \multirow{2}{*}{\multicolumn{2}{|c|}{$\frac{\text { TIROSINA }}{\text { Tiempo de cultivo }}$}} & \multirow{2}{*}{\multicolumn{2}{|c|}{$\frac{\text { L-DOPA }}{\text { Tiempo de cultivo }}$}} \\
\hline & & & & & & & \\
\hline & & & & $\begin{array}{c}1 \mathrm{~S} \mathrm{~S}^{\mathrm{a}} \\
\text { Callo } \\
(\mathrm{mg} / \mathrm{g} \\
\text { de peso seco) }\end{array}$ & $\begin{array}{c}72 \mathrm{~h}^{\mathrm{b}} \\
\text { Suspensión } \\
(\mathrm{mg} / \mathrm{g} \\
\text { de peso seco) }\end{array}$ & $\begin{array}{c}\frac{1 \mathrm{~S}^{\mathrm{a}}}{\text { Callo }} \\
(\mathrm{mg} / \mathrm{g} \\
\text { de peso seco) }\end{array}$ & $\begin{array}{c}1 \mathrm{~S}^{\mathrm{a}} \\
\text { Suspensión } \\
(\mathrm{mg} / \mathrm{g} \\
\text { de peso seco) }\end{array}$ \\
\hline dopaxantina (1) & 11.27 & 391 & 472 & $0.14 \pm 0.01$ & nd & $0.19 \pm 0.01$ & $1.68 \pm 0.01$ \\
\hline miraxantina V (2) & 12.54 & 347 & 460 & $\mathrm{nd}^{c}$ & $1.74 \pm 0.02$ & $1.17 \pm 0.03$ & $4.90 \pm 0.05$ \\
\hline betanidina (3) & 11.76 & 389 & 542 & nd & nd & $0.07 \pm 0.01$ & $0.64 \pm 0.01$ \\
\hline vulgaxantina I (5) & 8.45 & 340 & 472 & $0.08 \pm 0.01$ & $0.06 \pm 0.01$ & $0.70 \pm 0.01$ & $4.30 \pm 0.04$ \\
\hline triptófano-bx (6) & 10.09 & 398 & 472 & $0.03 \pm 0.01$ & $0.02 \pm 0.00$ & $0.22 \pm 0.01$ & $1.01 \pm 0.03$ \\
\hline betanina (7) & 10.25 & 551 & 535 & $0.96 \pm 0.01$ & $0.17 \pm 0.01$ & $2.90 \pm 0.06$ & $5.18 \pm 0.14$ \\
\hline iso-betanina & 16.67 & 551 & 535 & nd & nd & $0.24 \pm 0.01$ & $0.35 \pm 0.01$ \\
\hline amarantina (8) & 9.48 & 727 & 535 & $0.19 \pm 0.01$ & nd & $0.02 \pm 0.00$ & $0.01 \pm 0.00$ \\
\hline iso-amarantina & 9.81 & 727 & 535 & nd & nd & nd & nd \\
\hline ácido betalámico (10) & 12.05 & 211 & 405 & $0.13 \pm 0.01$ & $0.10 \pm 0.01$ & $0.60 \pm 0.01$ & $1.35 \pm 0.04$ \\
\hline
\end{tabular}

${ }^{a}$ S: semanas. bh: horas. ${ }^{c} \mathrm{ND}$ : no detectado. Se muestran los tiempos de retención $\left(T_{r}\right)$ de HPLC, iones moleculares determinados por ESI-MS, longitudes de onda máximas establecidas por DAD y las más altas concentración de betalaínas obtenidas en los cultivos a las 72 horas y una semana posterior a la inoculación de los precursores. 


\section{A.TIROSINA CALLO}

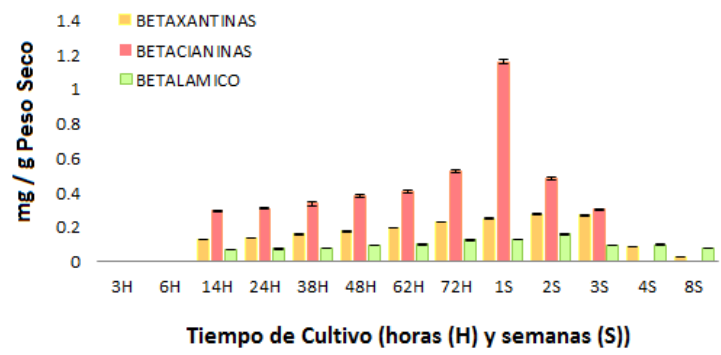

B. TIROSINA SUSPENSION

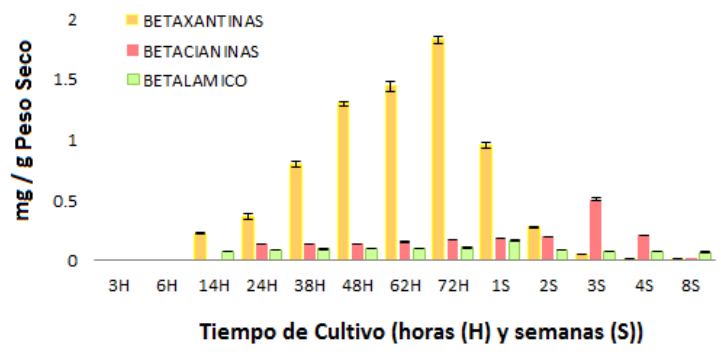

C. L-DOPA CALLO

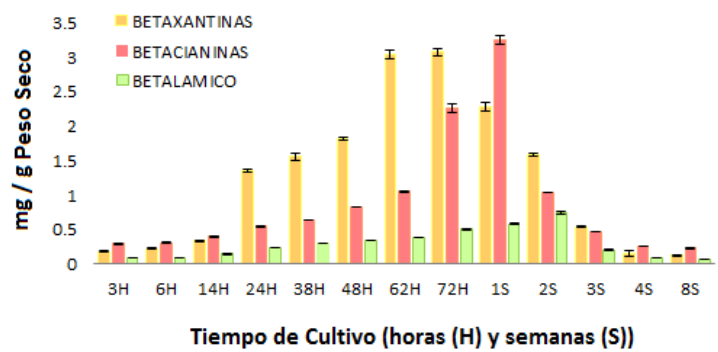

\section{L-DOPA SUSPENSION}

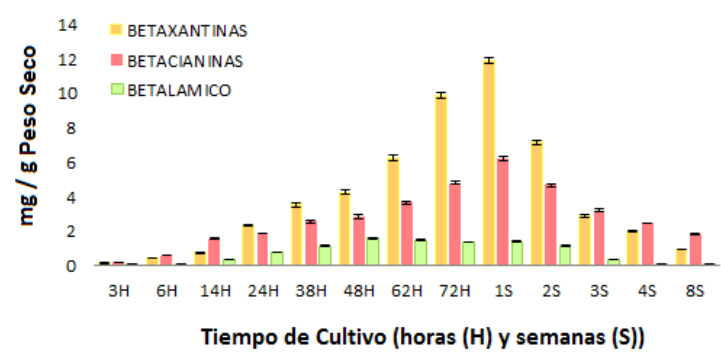

Figura 24. Producción de ácido betalámico y betalaínas en la línea celular de callo y suspensión de Amaranthus hypochondriacus variedad nutrisol, al adicionar $1.5 \mathrm{mM}$ de tirosina y L-DOPA. Las barras representan el error estándar de la media de tres mediciones independientes.

A
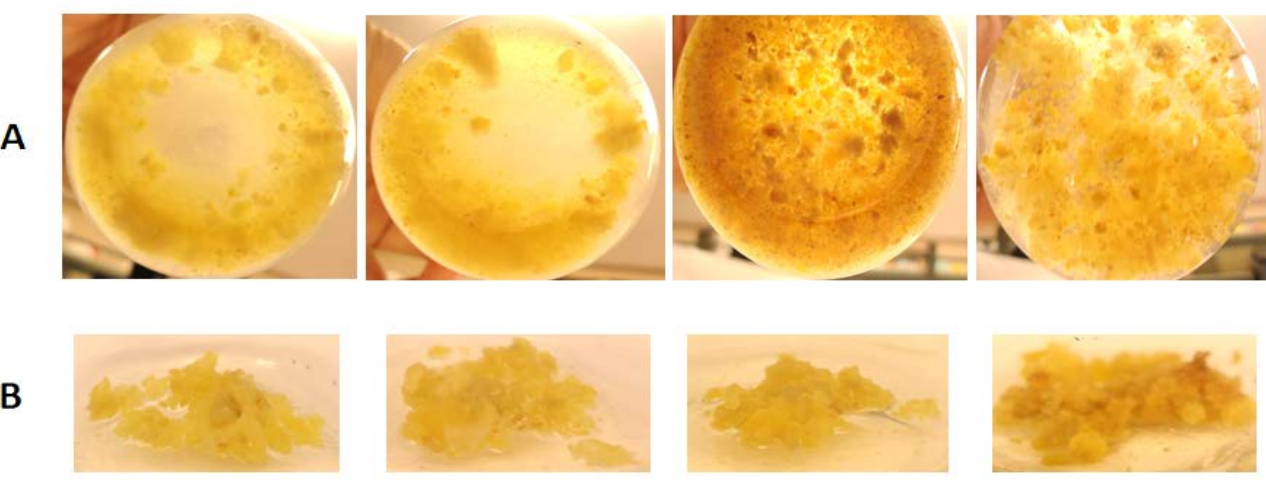

$48 \mathrm{H}$

$72 \mathrm{H}$

$1 \mathrm{~S}$

$2 \mathrm{~S}$

Tiempo de Cultivo (horas $(\mathrm{H})$ y semanas $(\mathrm{S})$ )

Figura 25. Evolución temporal de las características fenotípicas del cultivo en suspensión (A) y de callo (B) de Amaranthus hypochondriacus variedad nutrisol, al adicionar $1.5 \mathrm{mM}$ de tirosina. 


\section{A}
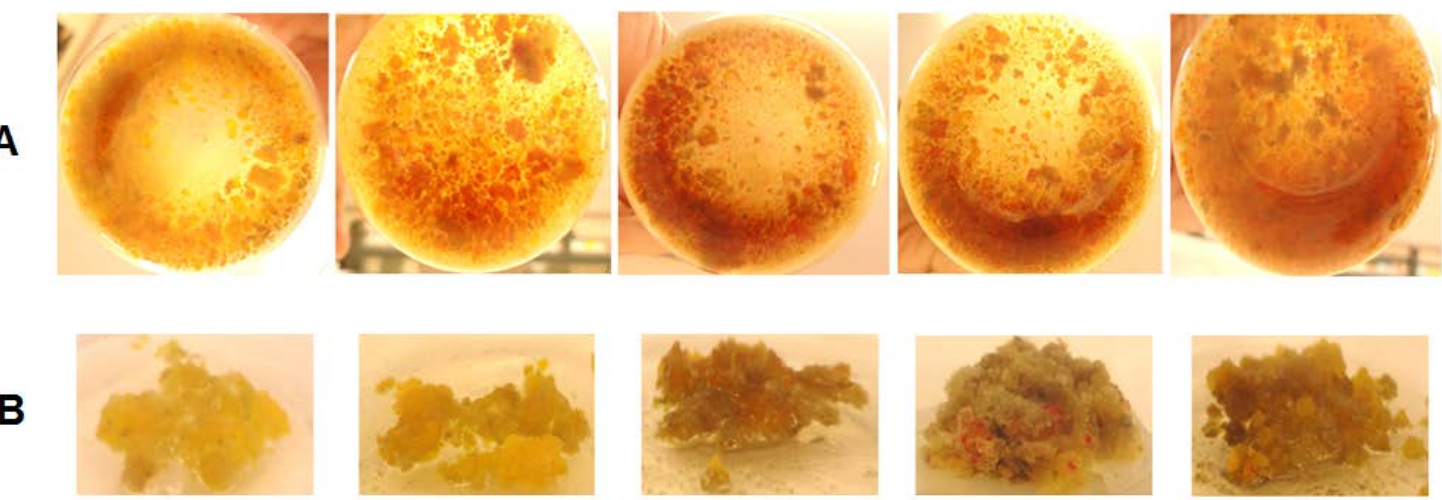

$48 \mathrm{H}$

$72 \mathrm{H}$

$1 \mathrm{~S}$

$2 \mathrm{~S}$

Tiempo de Cultivo (horas $(\mathrm{H})$ y semanas $(\mathrm{S})$ )

Figura 26. Evolución temporal de las características fenotípicas del cultivo en suspensión (A) y de callo (B) de Amaranthus hypochondriacus variedad nutrisol, al adicionar $1.5 \mathrm{mM}$ de L-DOPA.

\section{Influencia general de la respuesta al estrés abiótico y adición de precursores}

Los estudios sobre inducción de la síntesis de betalaínas, sugieren que las líneas celulares de A. hypochondricus fueron estimuladas positivamente por estrés abiótico (envejecimiento del cultivo, elicitores) y la biotransformación de las células por la adición de sustratos. Se demostró que la máxima producción de pigmentos se llevó a cabo en las líneas en suspensión expuestas a 1.5 mM de L-DOPA, una semana posterior a la inoculación (18.07 mg/ g de peso seco); seguido por los cultivos de callo, después de 10 semanas sin renovar el medio de cultivo (7.84 mg/g de peso seco); al añadir $1.5 \mathrm{mM}$ de tirosina en las suspensiones celulares, 72 horas después de la inoculación (1.99mg/g de peso seco); y en muy bajas proporciones en cultivos líquidos tratados con $100 \mu \mathrm{M}$ de MeJA (0.50 mg/g de peso seco) y $10 \mathrm{mM}$ de SA (0.06 mg/g de peso seco), a las 62 y 38 horas posteriores a la elicitación, respectivamente. 


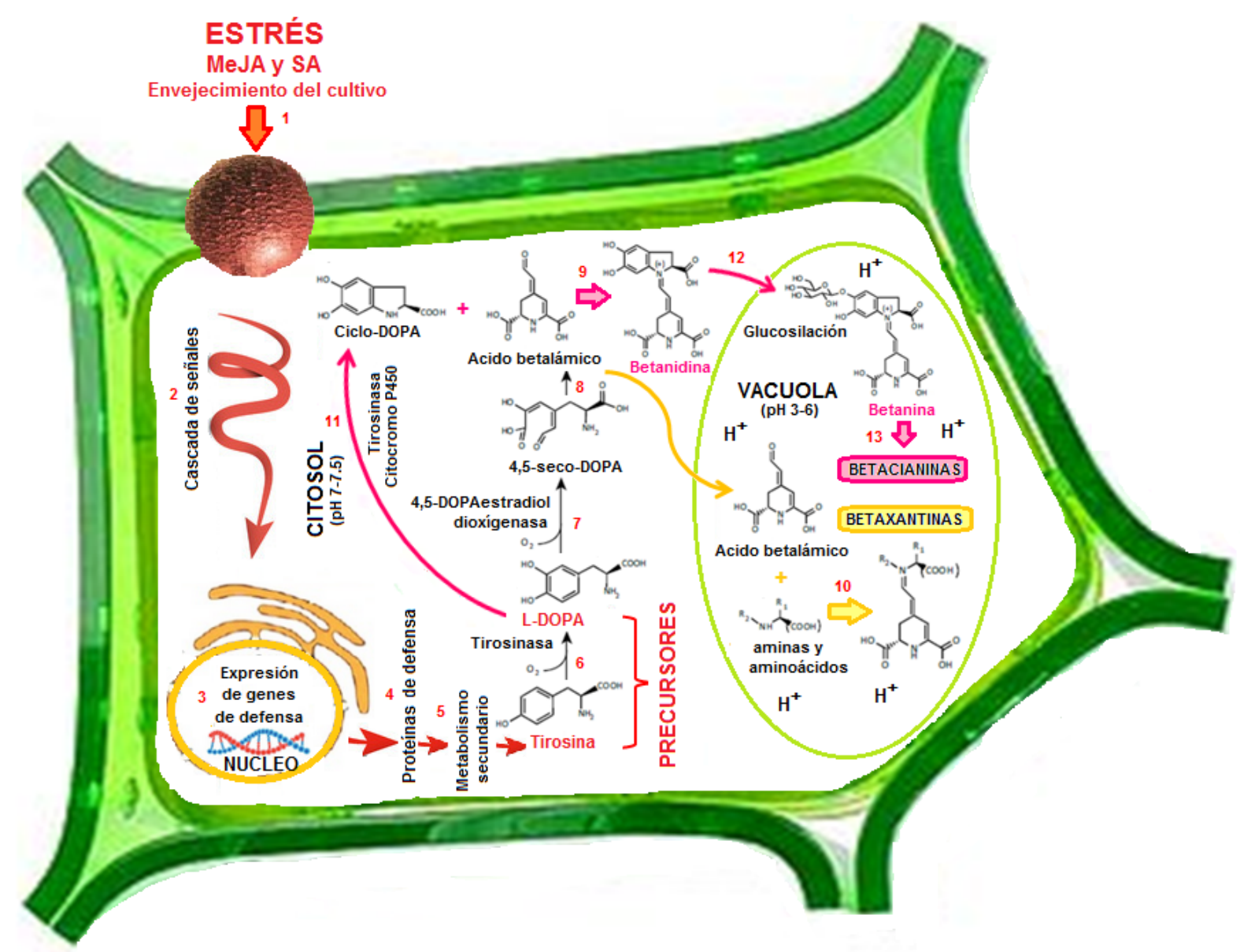

Figura 27. Influencia general de respuesta al estrés abiótico y a la adición de precursores sobre la ruta de biosíntesis de betalaínas en las líneas in vitro de $A$. hypochondriacus. Las flechas y los números representan la señalización celular y el camino metabólico recorrido en la ruta al ser estimuladas las células con envejecimiento del cultivo, MeJA, SA, tirosina y L-DOPA. Basado en Buchanan et al., 2000; Strack et al., 2003; Gandía Herrero y García Carmona, 2013. 
En general, la producción mayoritaria de betalaínas se obtuvo en las células en suspensión, probablemente debido a la presión osmótica presente en estos cultivos, la cual incrementa la acumulación intracelular de metabolitos secundarios (Radman et al., 2003; Baenas et al., 2014).

Este trabajo sugiere, que los cultivos in vitro de A. hypochondriacus, cuentan con la actividad de las enzimas clave de la ruta de biosíntesis de betalaínas: la tirosinasa y la 4,5DOPA-estradiol-dioxigena, así como la citocromo P450. No obstante, como sucede en varios cultivos vegetales, en este caso también se requirió de factores de estrés como el envejecimiento del cultivo, la elicitación del sistema, o bien la adición de moléculas precursoras de la vía de síntesis, para la acumulación de betalaínas (Figura 27). Probablemente el mecanismo de protección de las células de A. hypochondricus en respuesta al estrés abiótico inició con una cascada de señalización que provocó la expresión de genes y proteínas de defensa, que a su vez indujeron el metabolismo secundario (Buchanan et al., 2000), pudiéndose producir de esta manera tirosina y L-DOPA; o bien al agregar dichos precursores al medio de cultivo fue posible activar la maquinaria metabólica de síntesis de betacianinas y betaxantinas. 


\section{CONCLUSIONES}

1. Los cultivos de células de callo y suspensiones a nivel de matraz y biorreactor de $A$. hypochondriacus, obtenidos en medio MS con $6.66 \mu \mathrm{M}$ de BAP y $6.79 \mu \mathrm{M}$ de 2,4-D, producen un pigmento amarillo fluorescente, que no pertenece al grupo de las betalaínas.

2. Los cultivos de células de A. hypochondriacus, al ser estimuladas por estrés abiótico y adición de moléculas precursoras, producen dopaxantina, miraxantina V y betanidina; para dichas betalaínas dihidroxiladas se reporta la más alta actividad antirradical y antioxidante.

3. Los cultivos de células de A. hypochondriacus, estimulados con MeJA, tirosina y LDOPA, producen triptófano-betaxantina, que ha sido identificado como un importante compuesto bioactivo por su posible interacción con las sirtuinas enzimas relacionadas con el envejecimiento.

4. Las líneas celulares in vitro de A. hypochondriacus, representan un modelo apropiado para el estudio de los posibles factores implicados en la activación de la ruta de biosíntesis de betalaínas.

5. Los cultivos de A. hypochondriacus muestran la capacidad para convertirse en fuentes de pigmentos con aplicación potencial en la industria alimentaria, farmacéutica y cosmética. 
Capítulo 6.

\section{PRODUCCIÓN DE BETALAÍNAS DIHIDROXILADAS Y DOPAMINA EN CULTIVOS IN VITRO DE Celosia argentea variedad plumosa}




\section{TABLA DE CONTENIDO GRÁFICO}

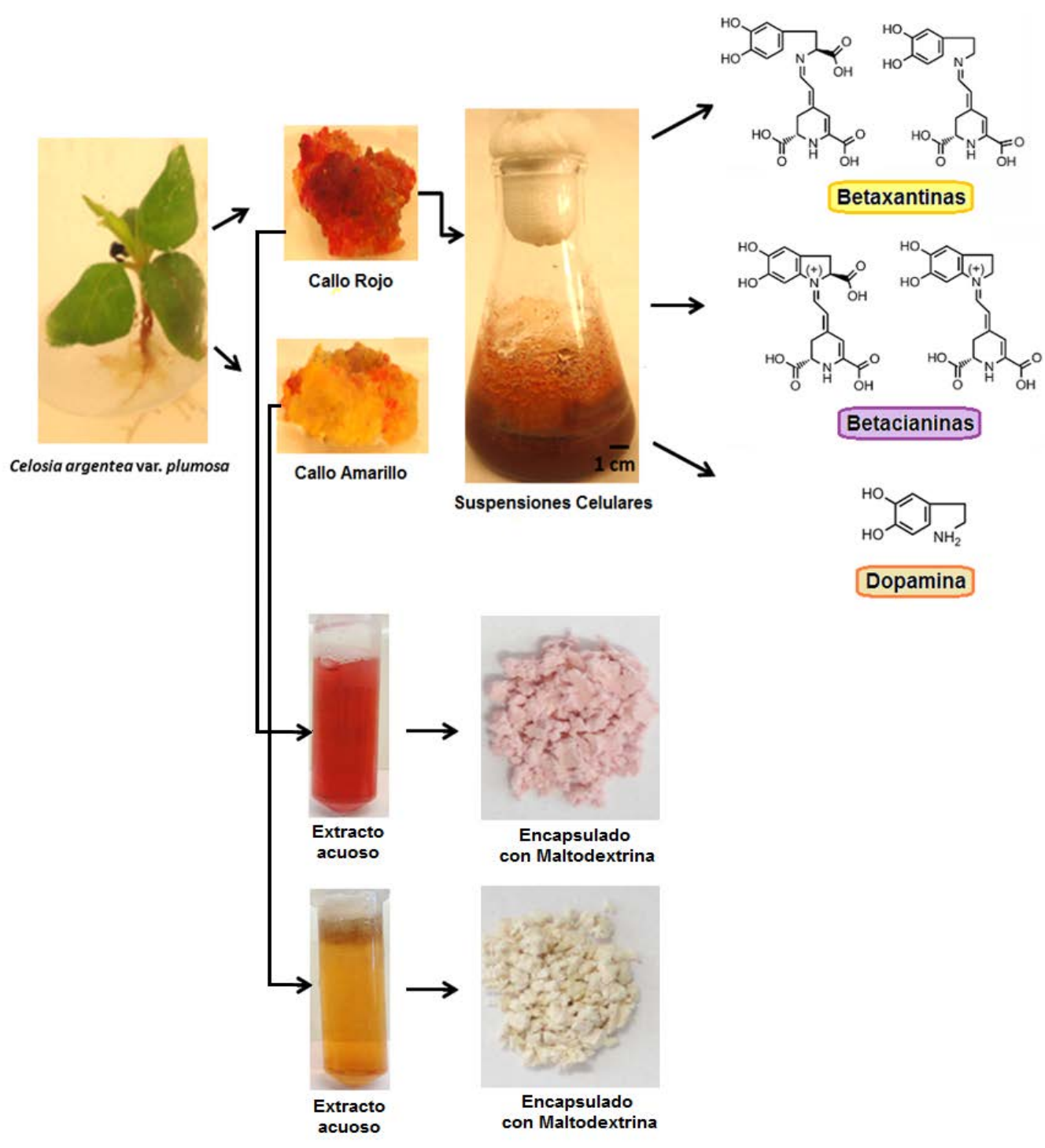

Este es el primer informe sobre la producción de betalaínas dihidroxiladas y dopamina en cultivos in vitro de Celosia argentea var. plumosa. Se realizó una encapsulación preliminar con maltodextrina de los extractos acuosos de callo rojo y amarillo. Se obtuvieron polvos solubles en agua de color rosa y amarillo, correspondiéndo esta coloración al conteniendo de betacianinas y betaxantinas, respectivamente. 


\section{RESUMEN}

Las betalaínas son pigmentos de las plantas de naturaleza hidrófila con potencial quimiopreventivo demostrado en líneas celulares de cáncer y modelos animales. Las betalaínas que contienen un anillo aromático con dos grupos hidroxilo libres poseen la más alta capacidad antioxidante y actividades de captura de radicales libres. Las betaxantinas dopaxantina y miraxantina $\mathrm{V}$, y las betacianinas betanidina y descarboxi betanidina son las únicas betalaínas naturales con subestructuras catecólicas. Estos cuatro pigmentos se han producido en cultivos celulares establecidos a partir de hipocótilos de la planta Celosia argentea. Dos líneas celulares estables y de color diferente, amarillo y rojo, se mantuvieron en medio MS suplementado con BAP 6.66 $\mu \mathrm{M}$ y 2,4-D 6.79 $\mu \mathrm{M}$. Extractos acuosos de estas dos líneas de callo fueron encapsulados con maltodextrina obteniéndose polvos de color rosa y amarillo. Los cultivos en suspensión derivados de la línea de callo rojo, mostraron un aumento de la producción de betalaínas dihidroxiladas en las células y secretadas al medio, con un máximo alcanzado después de 8 días de cultivo. Además, se obtuvieron las moléculas precursoras: ácido betalámico y dopamina, ésta última con un contenido de hasta 42,08 mg / g de peso seco. La presencia conjunta de las betalaínas bioactivas junto con dopamina y ácido betalámico, muestran la capacidad de los cultivos celulares de C. argentea para convertirse en una fuente estable de fitoquímicos valiosos con aplicación como colorantes naturales.

Palabras clave: betalainas, antiradical, bioactivo, dopamina, encapsulación. 


\section{ABSTRACT}

Betalains are hydrophilic pigments of plant with a chemopreventive potential demonstrated in cancer cell lines and animal models. Among the betalains, those containing an aromatic moiety with two free hydroxyl groups possess the strongest antioxidant and free radical scavenging activities. The betaxanthins dopaxanthin and miraxanthin $\mathrm{V}$, and the betacyanins betanidin and decarboxy-betanidin are the only natural betalains with catecholic sub-structures. These four pigments are produced in cell cultures established from Celosia argentea hypocotyls. Two stable and differentially colored callus cell lines, yellow and red, were maintained on MS medium supplemented with BAP 6.66 $\mu \mathrm{M}$ and 2,4-D $6.79 \mu \mathrm{M}$. Aqueous extracts of these calli were encapsulated with maltodextrin achieving powder pink and yellow. Derived suspension cultures show higher contents of dihydroxylated betalains in the cells than in the calli; compounds are accumulated and excreted to the medium with a maximum production after 8 days of culture. In addition, precursor molecules as the betalamic acid and dopamine were detected, with dopamine levels of $42.08 \mathrm{mg} / \mathrm{g}$ dry weight. The production of bioactive betalains with dopamine and betalamic acid precursors show the capacity of $C$. argentea cell cultures as a stable source for valuable phytochemicals with application as natural colorants.

Keywords: betalains, antiradical, bioactive, dopamine, encapsulation. 


\section{HIPÓTESIS}

Celosia argentea variedad plumosa sintetiza de manera natural betalaínas y dopamina, por lo que es posible establecer líneas celulares de la especie, capaces de producir estos compuestos bioactivos, utilizando reguladores del crecimiento como 2,4-D y BAP. 


\section{OBJETIVOS}

\section{OBJETIVO GENERAL}

Establecer el cultivo in vitro de Celosia argentea variedad plumosa, para la obtención, caracterización y protección de betalaínas y dopamina.

\section{OBJETIVOS ESPECÍFICOS}

A. Establecer cultivos asépticos de Celosia argentea variedad plumosa

B. Evaluar en explantes de hipocótilo de C. argentea var. plumosa, el efecto de distintas combinaciones de reguladores del crecimiento vegetal para la inducción de callo.

C. Establecer líneas celulares de C. argentea var. plumosa, en suspensión a nivel de matraz, a partir de los tratamientos con mayor crecimiento, friabilidad y pigmentación.

D. Caracterizar y cuantificar las betalaínas y la dopamina presentes en las líneas celulares de C. argentea var. plumosa.

E. Encapsular con maltodextina las betalaínas y la dopamina presentes en las líneas celulares de callo de C. argentea var. plumosa. 


\section{RESULTADOS Y DISCUSIÓN}

\section{Obtención de líneas celulares de callo de Celosia argentea var. plumosa.}

Todas las semillas de C. argentea var. plumosa germinaron 10 días después de su siembra, sin presentar contaminación por microorganismos. Las plántulas resultantes (Figura 29A) se mantuvieron bajo condiciones asépticas durante 20 días. Los hipocótilos se utilizaron como fuete de explantes para la inducción de callogénesis, actividad que se vio afectada por el tipo y concentración de los reguladores del crecimiento vegetal (Tabla 11). La presencia única de 2,4-D, no fue suficiente para inducir formación de callos. Tal inhibición del crecimiento celular podría corresponder a un aumento de auxinas en el explante, ya que se ha reportado que 2,4-D promueve la sobreexpresión de genes ARR7 y ARR15, represores de la retroalimentación de la señalización de citoquininas (Ying-Hua et al., 2011). La presencia de BAP a una concentración $4.44 \mu \mathrm{M}$, también derivó resultados negativos cuando no hay otro regulador presente, lo cual coincide con lo reportado en tratamientos de Celosia cristata (Taha y Wafa, 2012). Combinaciones de BAP $6.66 \mu \mathrm{M}$ con 2,4-D $8.88 \mu \mathrm{M}$ (Figura 28A), así como BAP $6.66 \mu \mathrm{M}$ con 2,4-D $9.05 \mu \mathrm{M}$ 2,4-D (Figura 28B) generaron callos de color marrón pálido con pequeños fragmentos rojos y amarillos, con rendimientos de 33\% o 66\%, respectivamente. Los experimentos con las mayores concentraciones de BAP y 2,4-D mostraron la capacidad de inducción a callo del 100 \% de callos blanco-verde a los 30 días de cultivo (Figura 28C). El medio suplementado con BAP $6.66 \mu \mathrm{M}$ y 2,4-D $6.79 \mu \mathrm{M}$, generó callos friables de color de color rojo y 
amarillo (Figura 28D), a los 30 días de cultivo. Estos datos concuerdan con las observaciones en la planta halófila Salsa suaeda (Zhao et al., 2011), en C. cristata (Taha y Wafa, 2012; Jamilah et al., 2014), y en cultivos de B. vulgaris cultures (Akita et al., 2000).
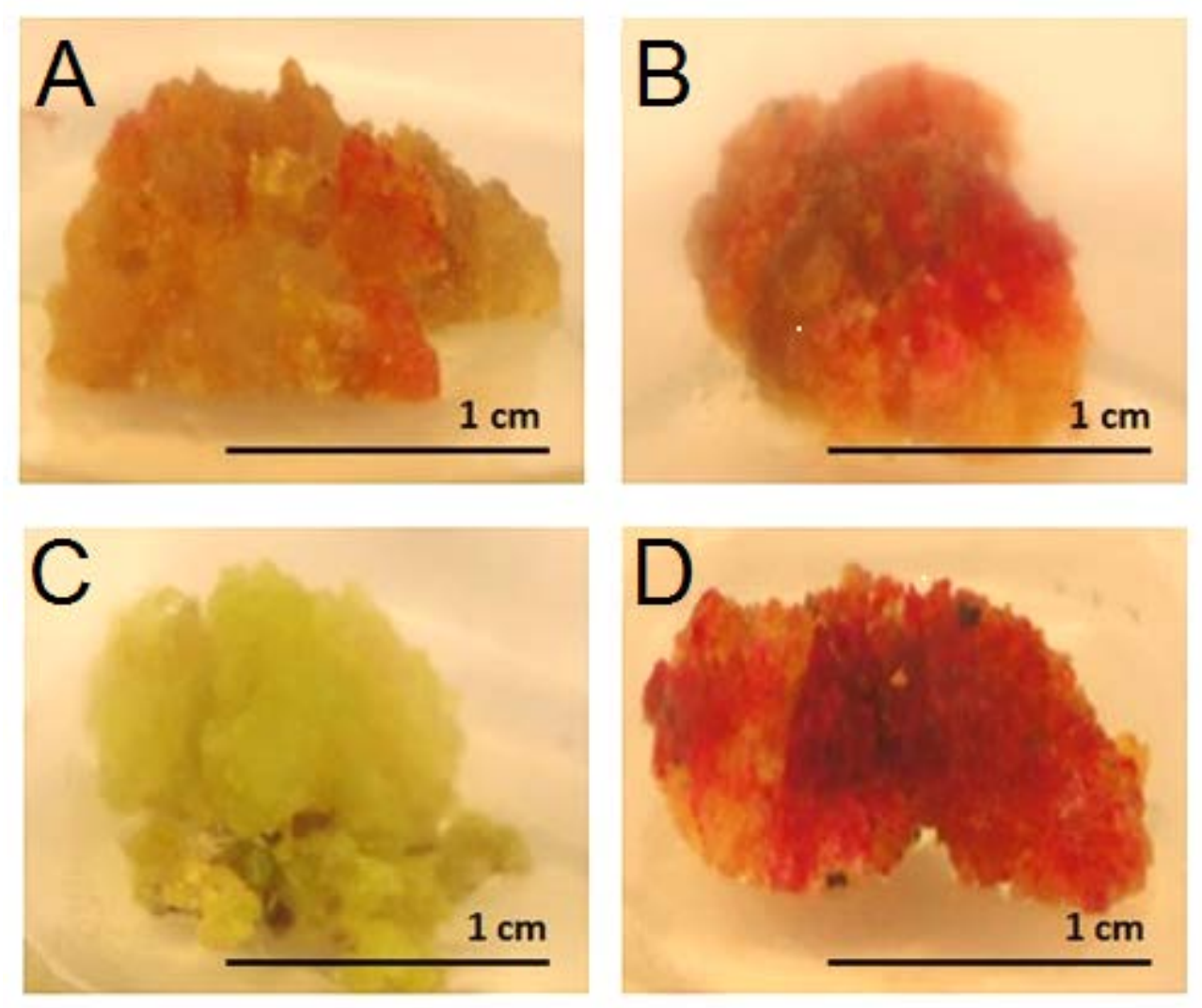

Figura 28: Características fenotípicas de callos inducidos en explantes de hipocótilos de Celosia argentea variedad plumosa a los 30 días de cultivo. (A) BAP $8.88 \mu \mathrm{M}$ y (B): BAP $6.66 \mu \mathrm{M}$ con 2,4-D 9.05 $\mu \mathrm{M}$, callos marrón con pequeños fragmentos rojos-amarillos en algunos extremos del tejido. (C) BAP $8.88 \mu \mathrm{M}$ con 2,4-D $9.05 \mu \mathrm{M}$, callo color blanco-verde. (D) BAP $6.66 \mu \mathrm{M}$ con 2,4-D $6.79 \mu \mathrm{M}$, callo color rojo-amarillo. 
Tabla 11. Efecto de los reguladores de crecimiento vegetal (RCV), sobre la inducción de callos a partir de explantes de hipocótilos de Celosia argentea var. plumosa después de 30 días de cultivo.

\begin{tabular}{|c|c|c|}
\hline \multicolumn{2}{|c|}{$\operatorname{RCV}(\mu \mathrm{M})$} & \multirow{2}{*}{$\begin{array}{c}\text { Explantes formando } \\
\text { callo }(\%)\end{array}$} \\
\hline BAP & 2,4-D & \\
\hline 0.00 & 0.00 & $0.00 \pm 0.00^{\mathrm{a}}$ \\
\hline 0.00 & 6.79 & $0.00 \pm 0.00^{\mathrm{a}}$ \\
\hline 0.00 & 9.05 & $0.00 \pm 0.00^{\mathrm{a}}$ \\
\hline 4.44 & 0.00 & $0.00 \pm 0.00^{\mathrm{a}}$ \\
\hline 4.44 & 6.79 & $0.00 \pm 0.00^{\mathrm{a}}$ \\
\hline 4.44 & 9.05 & $33.33 \pm 10.09^{a, b}$ \\
\hline 6.66 & 0.00 & $66.66 \pm 15.04^{b}$ \\
\hline 6.66 & 6.79 & $100.00 \pm 0.00^{b}$ \\
\hline 6.66 & 9.05 & $33.33 \pm 10.09^{\mathrm{a}, \mathrm{b}}$ \\
\hline 8.88 & 0.00 & $33.33 \pm 10.09^{a, b}$ \\
\hline 8.88 & 6.79 & $100.00 \pm 0.00^{b}$ \\
\hline 8.88 & 9.05 & $100.00 \pm 0.00^{\mathrm{b}}$ \\
\hline
\end{tabular}

Cada valor se deriva de tres tubos independientes que contenían cada uno tres diferentes explantes. Los valores que comparten la misma letra se corresponden con diferencias no significativas según la prueba de Tukey $(\mathrm{P}<0.05)$. 
La presencia de tonalidades rojas y amarillas, indicaba la presencia de betalaínas, con base a estas características del tejido, se determinó que el mejor medio para la propagación del callo fue el suplementado con BAP $6.66 \mu \mathrm{M}$ y 2,4-D $6.79 \mu \mathrm{M}$. La proliferación de este cultivo se llevó a cabo mediante subcultivos en medio fresco, con la misma fórmula de inducción cada 20 días durante 11 ciclos (tiempo total de cultivo 7.5 meses). Como resultado de este proceso se establecieron dos líneas de cultivo de callo para C. argentea, una de color amarillo y otra de color rojo (Figura 29B y 29C). Ambas líneas celulares obtenidas se observaron bajo microscopía. La línea amarilla mostró una forma celular redonda y pigmentación amarilla compatible con la presencia de betaxantinas (Figura 29E), y la línea de color rojo presentó una morfología celular redonda y alargada (Figura 29F). La pigmentación roja dentro de las células es compatible con la presencia de betacianinas.

\section{Identificación del pigmento en líneas celulares amarillas y rojas.}

Las líneas celulares de callos amarillos y rojos obtenidas de C. argentea fueron analizadas en términos de la presencia de betalaínas. Las muestras de ambas líneas fueron extraídas y analizadas por HPLC con detección de DAD y ESI-MS / MS (Tabla 12). La línea amarilla exhibió la mayor presencia de betaxantinas como vulgaxantina I (5), derivado de Lglutamina (1,78 mg / g seco peso) y miraxantina V (2) y, derivado de la dopamina (1,64 mg / g de peso seco) (Tabla 12). También se detectaron betaxantinas provenientes de Ldihidroxifenilalanina (L-DOPA), dopaxantina (1) y L-triptófano (6). Además de los pigmentos amarillos, se encontraron las betacianinas amarantina (8) y betanina (7) y la 
betanidina (3); asimismo se identificó una descarboxi-betanidina (4). En la línea roja, la coloración también se debió a las betalaínas y el contenido de betacianinas fue mayor. La amarantina (8) fue el pigmento mayoritario (4,92 mg / g seco peso), acompañado de la descarboxi-betanidina (4) (1,32 mg / g peso seco), betanina (7) (0,80 mg / g de peso seco), y betanidina (3) (0,74 mg / g de peso seco) (Tabla 12). Las betaxantinas también estuvieron presentes, la betaxantina derivada de dopamina (2) fue el mayor constituyente del pigmento amarillo (3,04 $\mathrm{mg} / \mathrm{g}$ de peso seco). La presencia conjunta de betacianinas (violeta) y betaxantinas (amarillo) produce el color rojo descrito para la masa celular. Las inflorescencias e hipocótilos, éste último utilizado como material vegetal de partida para establecer las líneas celulares, presentaron una coloración violeta, y en estos órganos sólo se encontró la presencia de amarantina (8) y su isómero iso-amarantina (Tabla 12). El número de betalaínas presentes en los cultivos celulares indica que $6.79 \mu \mathrm{M}$ de 2,4-D y 6.66 $\mu$ M BAP, podrían estar favoreciendo la estimulación de la biosíntesis de un mayor número de betalaínas en comparación con el material vegetal de partida. Esto probablemente debido al efecto del 2,4-D y BAP, sobre la expresión de las enzimas clave de la ruta biosintética de betalaínas: dioxigenasa 4,5-DOPA-extradiol (DODA), tirosinasa, y citocromo P450. En este sentido, los niveles de mRNA de DODA y la acumulación de betalaínas han sido previamente correlacionadas con la concentración de los reguladores del crecimiento en cultivos in vitro de S. salsa (Zhao et al., 2011). 

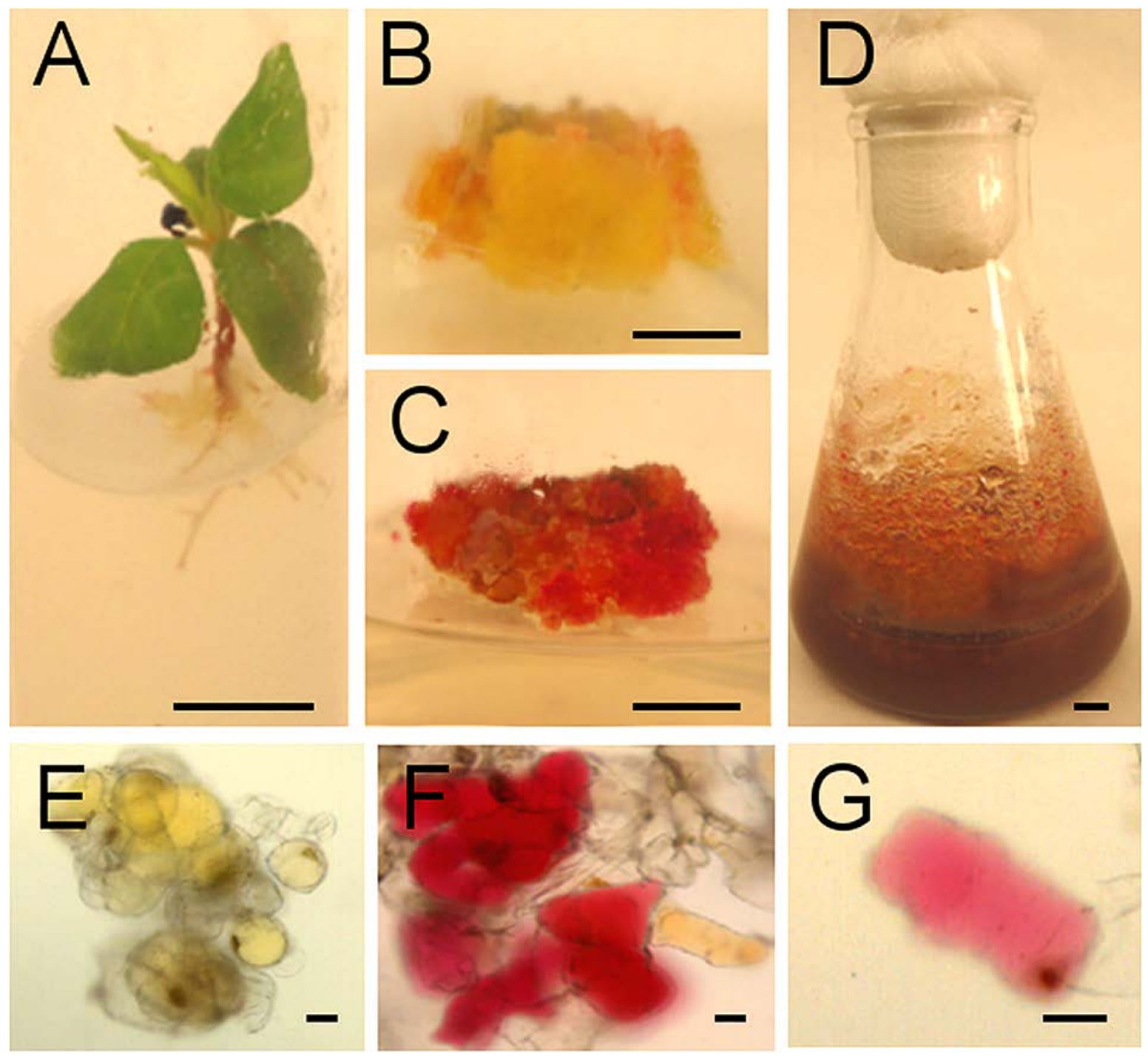

Figura 29. Establecimiento de líneas celulares in vitro derivadas de C. argentea var. plumosa. (A) Plántulas de veinte días de edad fueron utilizadas como fuente de explantes. (B y C) imágenes macroscópicas que muestra las características fenotípicas de líneas de callos amarillo y rojo, respectivamente. (D) Cultivo de células en suspensión 15 días después de subcultivo. ( $E$, F y G) Imágenes microscópicas de campo claro de células presentes en el callo de color amarillo, rojo y cultivo en suspensión, respectivamente. Barra en A, B, C y D equivale a 1 cm; en E, F y G a $10 \mu \mathrm{m}$. 
Tabla 12. Producción de betalaínas, dopamina y ácido betalámico en las líneas celulares de callo amarillo y rojo y en cultivos en suspensión de C. argentea.

\begin{tabular}{|c|c|c|c|c|c|c|c|c|c|c|c|}
\hline \multirow[b]{2}{*}{ COMPUESTO } & \multirow[b]{2}{*}{$\begin{array}{c}\boldsymbol{T}_{\boldsymbol{r}} \\
(\mathrm{min})\end{array}$} & \multirow[b]{2}{*}{$\begin{array}{c}\text { ESI-MS } \\
(m / z)\end{array}$} & \multirow[b]{2}{*}{$\begin{array}{l}\lambda_{\max } \\
(\mathrm{nm})\end{array}$} & \multirow{2}{*}{$\begin{array}{c}\operatorname{infl}^{a} \\
(\mathrm{mg} / \mathrm{g} \\
\text { peso seco) }\end{array}$} & \multirow{2}{*}{$\begin{array}{c}\operatorname{hip}^{b} \\
\text { (mg/g } \\
\text { peso seco) }\end{array}$} & \multirow{2}{*}{$\begin{array}{c}\text { línea } \\
\text { amarilla } \\
\text { (mg/g } \\
\text { peso seco) }\end{array}$} & \multirow{2}{*}{$\begin{array}{c}\text { línea } \\
\text { roja } \\
\text { (mg/g } \\
\text { peso seco) }\end{array}$} & \multicolumn{4}{|c|}{ cultivos en suspensión } \\
\hline & & & & & & & & $\begin{array}{r}1 \text { día } \\
\text { pes }\end{array}$ & $\begin{array}{c}8 \text { dias (mg / g } \\
\text { peso seco) }\end{array}$ & $\begin{array}{c}15 \text { días (mg / g } \\
\text { peso seco) }\end{array}$ & $\begin{array}{r}30 \text { dias (mg / g } \\
\text { peso seco) }\end{array}$ \\
\hline dopaxantina (1) & 11.27 & 391 & 472 & $\mathrm{nd}^{c}$ & nd & $0.22 \pm 0.01$ & $0.34 \pm 0.01$ & $0.31 \pm 0.01$ & $0.29 \pm 0.02$ & $0.16 \pm 0.01$ & $0.12 \pm 0.01$ \\
\hline miraxantina $\mathbf{V}(2)$ & 12.54 & 347 & 460 & nd & nd & $1.64 \pm 0.01$ & $3.04 \pm 0.02$ & $1.84 \pm 0.07$ & $1.47 \pm 0.06$ & $1.49 \pm 0.09$ & $0.52 \pm 0.02$ \\
\hline betanidina (3) & 11.76 & 389 & 542 & nd & nd & $0.45 \pm 0.01$ & $0.74 \pm 0.03$ & $2.05 \pm 0.04$ & $6.27 \pm 0.05$ & $2.46 \pm 0.07$ & $0.39 \pm 0.04$ \\
\hline $\begin{array}{l}\text { descarboxi- } \\
\text { betanidina }\end{array}$ & 13.37 & 345 & 539 & nd & nd & $0.71 \pm 0.01$ & $1.32 \pm 0.05$ & $2.16 \pm 0.05$ & $2.30 \pm 0.06$ & $2.21 \pm 0.08$ & $0.34 \pm 0.01$ \\
\hline vulgaxantina I (5) & 8.45 & 340 & 472 & nd & nd & $1.78 \pm 0.01$ & $2.65 \pm 0.01$ & $2.01 \pm 0.08$ & $2.01 \pm 0.1$ & $0.15 \pm 0.04$ & $0.09 \pm 0.03$ \\
\hline triptófano-bx (6) & 10.09 & 398 & 472 & nd & nd & $0.12 \pm 0.01$ & $0.11 \pm 0.01$ & $0.23 \pm 0.02$ & $0.26 \pm 0.02$ & $0.01 \pm 0.01$ & $0.02 \pm 0.01$ \\
\hline betanina $(7)$ & 10.25 & 551 & 535 & nd & nd & $0.62 \pm 0.03$ & $0.80 \pm 0.01$ & $0.95 \pm 0.03$ & $0.75 \pm 0.05$ & $0.33 \pm 0.03$ & $0.15 \pm 0.01$ \\
\hline iso-betanina & 16.67 & 551 & 535 & nd & nd & $0.94 \pm 0.01$ & $1.25 \pm 0.01$ & $1.43 \pm 0.07$ & $0.67 \pm 0.08$ & $0.30 \pm 0.07$ & $0.49 \pm 0.04$ \\
\hline amarantina $(8)$ & 9.48 & 727 & 535 & $18.68 \pm 0.16$ & $6 \quad 1.52 \pm 0.04$ & $41.37 \pm 0.01$ & $4.92 \pm 0.02$ & $0.62 \pm 0.04$ & $0.48 \pm 0.02$ & $0.61 \pm 0.04$ & $0.2 \pm 0.02$ \\
\hline iso-amarantina & 9.81 & 727 & 535 & $6.20 \pm 0.05$ & $0.60 \pm 0.09$ & $0.21 \pm 0.01$ & $0.81 \pm 0.01$ & $0.65 \pm 0.01$ & $0.22 \pm 0.05$ & $0.03 \pm 0.01$ & $0.01 \pm 0.01$ \\
\hline dopamina (9) & 8.60 & 137 & 278 & nd & nd & $17.70 \pm 0.05$ & $19.62 \pm 0.06$ & $35.28 \pm 0.12$ & $42.08 \pm 0.15$ & $15.48 \pm 0.11$ & $0.94 \pm 0.14$ \\
\hline ácido betalámico $(10)$ & 12.05 & 211 & 405 & nd & nd & $0.29 \pm 0.02$ & $0.46 \pm 0.01$ & $0.32 \pm 0.06$ & $0.29 \pm 0.06$ & $0.13 \pm 0.02$ & $0.14 \pm 0.03$ \\
\hline
\end{tabular}

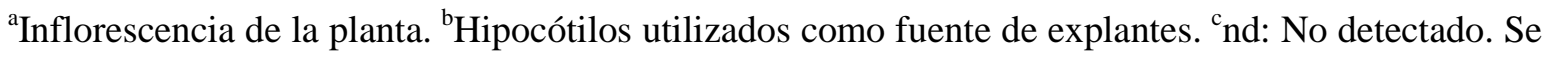
muestran los tiempos de retención $\left(T_{r}\right)$ de HPLC, iones moleculares determinados por ESI-MS y longitudes de onda máximas establecidas por DAD. Los pigmentos analizados en inflorescencias de toda la planta y en hipocótilos se muestran para comparación.

La Figura 30 muestra las imágenes derivadas de la fluorescencia de las betaxantinas. Como puede verse, sólo las porciones de color amarillo de la imagen de campo claro, que contienen el pigmento amarillo, presenta emisión de luz en la imagen de fluorescencia. Anteriormente la fluorescencia de betaxantinas se había utilizado para visualizar células de pétalos (Gandía-Herrero et al., 2005), y para detectar la presencia de Plasmodium falciparum (malaria) en eritrocitos (Goncalves et al., 2013). Sin embargo, esta es la primera ocasión que la fluorescencia de las betalaínas demostró ser de utilidad en la visualización de células individuales de plantas cultivadas in vitro. 

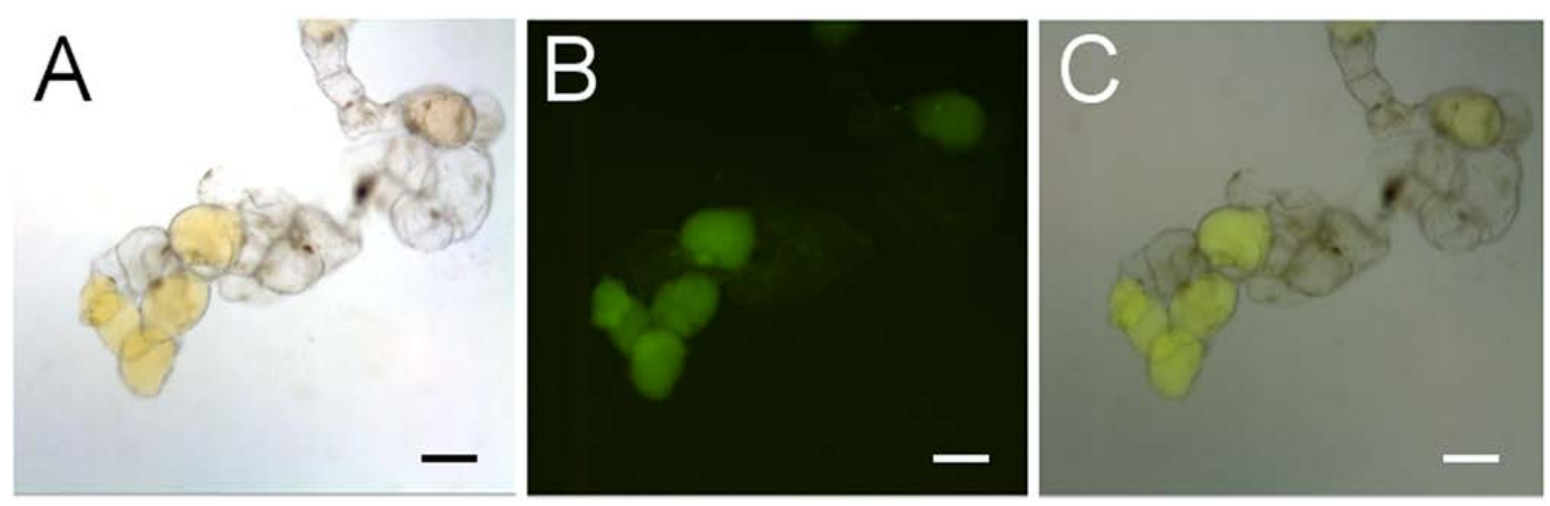

Figura 30. Micrografía de las células de la línea de callo amarillo de C. argentea. (A) Técnica de campo claro. (B) Técnica de fluorescencia. Sólo las porciones amarillas de la imagen de campo claro, que contienen betaxantinas, presentan emisión de luz en el perfil de fluorescencia. (C) Combinación de las dos imágenes anteriores.

Todos los pigmentos se identificaron por comparación con estándares en términos de tiempos de retención $\left(T_{r}\right)$ de HPLC, espectros DAD y análisis de espectrometría de masas de ionización por electrospray (ESI-MS). Los valores de masa determinados para los iones de partida de todos los compuestos fueron los esperados para los correspondientes iones moleculares protonados $[\mathrm{M}+\mathrm{H}]^{+}$de las betalaínas, confirmando de esta manera las estructuras propuestas (Tabla 12). Para los pigmentos que contienen una subestructura de amonio cuaternario, la masa obtenida corresponde a la forma cargada. En todos los casos el ion resultante correspondiente a $m / z[\mathrm{M}+\mathrm{H}]^{+}-44$ se detectó, lo que representa la pérdida de un grupo carboxílico. Para betanina (7) ( $T_{r}$ 10,25 min), el fragmento resultante principal presentó $m$ / z 389, correspondiente a la masa determinada para betanidina (3), obtenido a través de la escisión de la unidad de glucosa en el nivel del enlace $O$-glucosídico $(\mathrm{m} / \mathrm{z}$ [M 
$+\mathrm{H}]^{+}$- 162). Amarantina (8) ( $\left.T_{r} 9,48 \mathrm{~min}\right)$ proporcionó un ion molecular de $m$ / z 727 que al ser fragmentado presentó una $m$ / z 551, correspondiente a la pérdida de un residuo de ácido glucurónico $m / z[\mathrm{M}+\mathrm{H}]^{+}-176$ (betanina), y en $m / z$ 389, correspondiente a la pérdida adicional de glucosa $m / z[\mathrm{M}+\mathrm{H}]^{+}$-176-162 (betanidina). Betanidina (3) también se detectó en los extractos derivados de ambas líneas celulares ( $T_{r}$ 11,76 min). Por lo tanto, todos los productos intermedios de la ruta bioquímica de formación de las betacianinas carboxiladas desde betanidina hasta amarantina estuvieron presentes. Esto sugiere la transformación de betanidina (3) en betanina (7) por glucosilación (Hans et al., 2004), y betanina en amarantina (8) mediante la adición de un residuo de ácido glucurónico. La presencia de los compuestos intermedios apunta a la biosíntesis de amarantina en el callo a través de esta ruta en lugar de la glucosilación y la glucuronilación de ciclo-DOPA y la posterior condensación con betanidina (Sasaki et al., 2005). Estos intermediarios no estuvieron presentes en la inflorescencia e hipocótilos de la planta de partida, en los cuales sólo se detectó el producto final de la ruta: la amarantina. La posible presencia en los cultivos de células de la unidad estructural de todas las betalaínas, el ácido betalámico (10), y el precursor molécular para la miraxantina V, así como la dopamina (9), también fue investigado. El ácido betalámico se pudo detectar en la línea celular amarilla de $C$. argentea en 0,29 mg / g de peso seco (Tabla 12), mientras que en la línea roja se detectó un contenido más alto con 0,46 mg / g seco de peso. La presencia de ácido betalámico (10) complementa la presencia de compuestos intermedios de la ruta biosintética de betalaínas. Es una molécula difícil de detectar, debido a la ciclación casi espontanea de la molécula de 4,5-seco-DOPA obtenido por la escisión intramolecular del aminoácido L-DOPA por la 
enzima 4,5-DOPA-extradiol-dioxigenasa (Gandía-Herrero y García-Carmona, 2013). El ácido betalámico libre se ha encontrado previamente como un componente natural de frutos de Opuntia ficus-indica (42). La dopamina (9) también se detectó en las líneas celulares en cantidades significativas. La identificación fue corroborada por comparación con el estándar comercial ( $T_{r} 8.60$ min) y ESI-MS. El ion residual predominante de $m$ / z 137 resultante de la pérdida del grupo amina se encontró como derivado de este compuesto. Este metabolito no se detectó en las inflorescencias e hipocótilos de las plantas de partida, sin embargo se encontraron cantidades importantes en la línea celular de callo amarillo con $17.70 \mathrm{mg}$ / g de peso seco y $19.63 \mathrm{mg} / \mathrm{g}$ peso seco en la línea roja. Además de su papel clave en la construcción estructural de las betalaínas, el ácido betalámico es un pigmento natural con fuerte actividad antioxidante (Gandía-Herrero et al., 2012). Por su parte la dopamina es un neurotransmisor, y se ha informado que su déficit origina enfermedades mentales tales como depression (Dunlop y Nemeroff, 2007). La presencia de betacianinas dihidroxiladas como betanidina (3) y descarboxi-betanidina (4), así como la dopa y la dopamina betaxantinas (1 y 2) en las líneas celulares obtenidas, es de particular importancia debido a su potente capacidad antioxidante y su actividad de eliminación de radicales libres (Gandía-Herrero et al., 2009; Gliszczynska-Swigło et al., 2006; Cai et al., 2003). Además, la presencia de la betaxantina derivada de triptófano (6) en ambas líneas celulares resulta trascendente, ya que recientemente se ha identificado en la medicina tradicional china como un compuesto bioactivo que interactúa con las sirtuinas, enzimas relacionadas con el envejecimiento (Chen et al., 2013). La triptófano betaxantina es un 
compuesto con posible aplicación en el desarrollo de medicamentos para enfermedades asociadas con el envejecimiento.

\section{Cultivos en suspensión de $C$. argentea}

Los análisis realizados en las líneas celulares derivadas de C. argentea reportaron que la línea roja produce niveles más altos de dopamina, betacianinas, y betaxantinas que el homólogo de color amarillo (Figura 31C). Por lo tanto, la línea celular de color rojo fue elegida para iniciar el cultivo en suspensión de C. argentea que podría ser utilizado para producir los fitoquímicos identificados. El cultivo líquido fue establecido con éxito en medio MS suplementado con 30 g / L de sacarosa, $6.66 \mu \mathrm{M}$ BAP, $6.79 \mu \mathrm{M}$ 2.4-D, y 10 mM ácido ascórbico (Figura 29D). La cinética de crecimiento celular (Figura 32) indica que la fase lag o de retardo, constó de 4 días, en los que la biomasa alcanzó 3.18 g peso seco / L. Después de este tiempo, las células alcanzaron la fase de crecimiento exponencial, hasta el día 15, tiempo al cual el acumulado de biomasa fue de 10.96 g peso seco / L. Durante esta fase, el tiempo de duplicación del cultivo fue de 6.1 días con una tasa de crecimiento $(\mu)$ de 0.113 / día. Durante todo el tiempo de cultivo el pH de la suspensión fue supervisado (resultados no mostrados) sin variación significativa, presentando un valor medio de $\mathrm{pH}$ de 4.9. Este valor de $\mathrm{pH}$ es apropiado para promover la estabilidad de los pigmentos betalainas con especial énfasis en aquellos que contienen la subestructura dihidroxilada (Gandía-Herrero et al., 2013). La morfología de las células en suspensión fue alargada, mostrando predominantemente coloración roja (96\%) (Figura 29G), también se visualizaron células globulares amarillas en un grado mucho menor (4\%) en todos los 
cultivos. La presencia conjunta de betaxantinas y betacianinas en la mayoría de las células, tal como se detectó en el callo rojo utilizado para iniciar el cultivo líquido. Las células presentaron la tendencia a formar agregados, probablemente por la lignificación de las paredes celulares debido al contenido de fenoles simples, o bien a la relación de las propiedades de cohesión de la pared celular y el estrés hidrodinámico (Trejo-Tapia y Rodríguez-Monroy, 2007).

La viabilidad celular del cultivo en suspensión fue también monitoreada durante el proceso y se observó que ésta se mantuvo en un 74\% durante los 30 días del período de cultivo (Figura 32B), por lo que se consideró un cultivo en suspensión de células de $C$. argentea (viabilidad celular > a 50\%), establecido exitosamente.

\section{Producción de betalaínas y dopamina en cultivos en suspensión de C. argentea}

La presencia de betalaínas y dopamina en cultivos líquidos se analizó por HPLC-DAD y ESI-MS. Los pigmentos se identificaron y se cuantificaron tanto en las células en suspensión como en el medio líquido a diferentes tiempos de cultivo. Los extractos celulares y el análisis de medios de cultivo se realizaron a los días 1, 8, 15, y 30 como se muestran en las Tablas 12 y 13. 

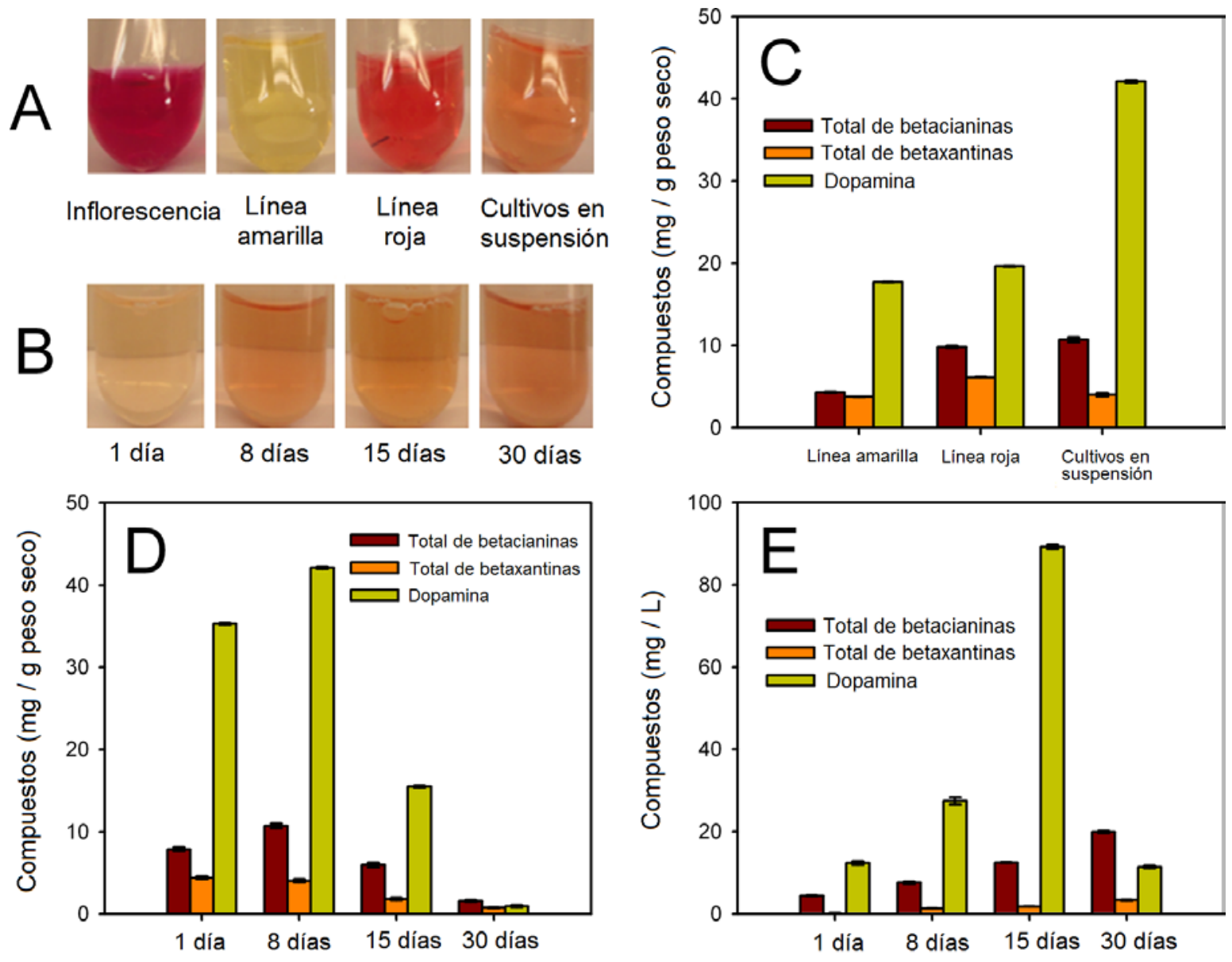

Figure 31. Producción de betalaínas y dopamina por las líneas celulares derivadas de $C$. argentea var. plumosa. (A) La imagen muestra la pigmentación de los extractos celulares obtenidos de las inflorescencias de la planta, la línea de callo amarilla, la línea de callo roja, y el cultivo en suspensión 8 días después de subcultivo. (B) Evolución del color en el medio de cultivo líquido a los días 1, 8, 15, y 30 después del subcultivo. (C) Contenido total de pigmentos y la presencia de dopamina obtenidos en los extractos de cultivos semi-sólidos y en suspensión. (D) Evolución temporal para la producción de betalaínas y dopamina en las células del cultivo en suspensión en los tiempos indicados después del subcultivo. (E) Evolución temporal de la presencia de betalaínas y dopamina en el medio líquido en los tiempos indicados después del subcultivo. 


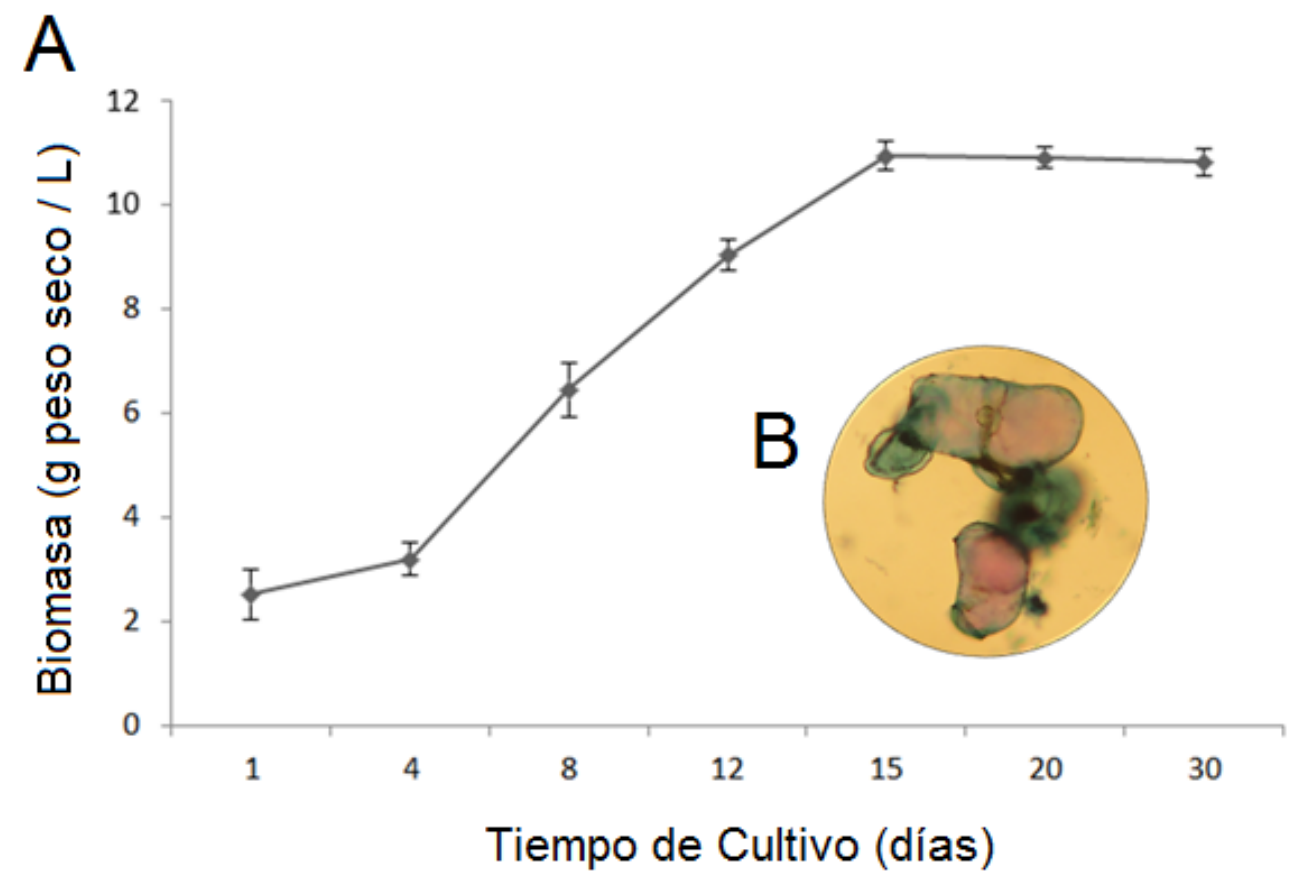

Figura 32. Curva de crecimiento para el cultivo en suspensión de C. argentea obtenido en medio líquido MS suplementado con $30 \mathrm{~g}$ / L de sacarosa, $6.66 \mu \mathrm{M}$ de BAP, $6.79 \mu \mathrm{M}$ 2,4-D, y $10 \mathrm{mM}$ de ácido ascórbico. (A) Evolución temporal del crecimiento. (B) Viabilidad celular determinada a los 8 días por la prueba de tinción con azul del Evans.

La máxima acumulación de betalaínas en las células se exhibió al día 8, correspondiente a la fase de crecimiento exponencial (Figura 31D). Se identificó la presencia de 10 pigmentos en la biomasa celular de los callos, con un mayor contenido de miraxanthin V (2) (1.84 mg / g de peso seco), vulgaxantina I (5) (2.01 mg / g de peso seco), y betanidina (3) (6.27 mg / g de peso seco). Este contenido de pigmento explica la coloración de la suspensión celular y sugiere la posible secreción de pigmentos en el medio de cultivo (Tabla 13). La presencia 
de betalaínas en el medio de cultivo se detectó durante todo el proceso, aumentando con el tiempo de incubación (Figura 31B y 31E). Los pigmentos identificados fueron ácido betalámico (10), vulgaxantina I (5), miraxantina V (2), amarantina (8), y betanidina (3). La cantidad total de betalaínas detectada al final del cultivo (día 30) fue de 23.27 mg / L, de este valor corresponde el $13.40 \mathrm{mg}$ / L a la betacianina dihidroxi-betanidina (3). La betanidina, es la betalaína con la actividad antioxidante y la capacidad antirradical más alta, además los extractos que contienen betalaínas presentan potencial anti-inflamatorio (Vidal et al., 2014; Martinez et al., 2014).

Tabla 13. Producción de betalaínas, dopamina y ácido betalámico en el medio líquido de cultivos en suspensión de $C$. argentea.

\begin{tabular}{|c|c|c|c|c|}
\hline COMPUESTO & 1 día $(\mathrm{mg} / \mathrm{L})$ & 8 dias $(\mathrm{mg} / \mathrm{L})$ & 15 dias $(\mathrm{mg} / \mathrm{L})$ & 30 dias $(\mathrm{mg} / \mathrm{L})$ \\
\hline dopaxantina (1) & $\mathrm{nd}^{a}$ & nd & nd & nd \\
\hline miraxantina $\mathbf{V}(2)$ & $0.03 \pm 0.01$ & $0.40 \pm 0.05$ & $0.50 \pm 0.02$ & $1.17 \pm 0.04$ \\
\hline betanidina $(3)$ & $0.50 \pm 0.04$ & $2.85 \pm 0.11$ & $6.75 \pm 0.02$ & $13.40 \pm 0.04$ \\
\hline $\begin{array}{l}\text { descarboxi- } \\
\text { betanidina }\end{array}$ & $1.14 \pm 0.05$ & $1.51 \pm 0.20$ & $2.47 \pm 0.03$ & $4.17 \pm 0.09$ \\
\hline vulgaxantina I (5) & $0.08 \pm 0.03$ & $0.88 \pm 0.02$ & $1.24 \pm 0.03$ & $2.16 \pm 0.06$ \\
\hline triptófano-bx (6) & nd & nd & nd & nd \\
\hline betanina $(7)$ & nd & nd & nd & nd \\
\hline iso-betanina & nd & nd & nd & nd \\
\hline amarantina $(8)$ & $2.70 \pm 0.07$ & $3.04 \pm 0.11$ & $2.99 \pm 0.02$ & $2.33 \pm 0.08$ \\
\hline iso-amarantina & $0.04 \pm 0.01$ & $0.12 \pm 0.04$ & $0.24 \pm 0.03$ & $0.04 \pm 0.03$ \\
\hline dopamina (9) & $12.34 \pm 0.48$ & $27.42 \pm 0.85$ & $89.20 \pm 0.51$ & $11.35 \pm 0.35$ \\
\hline ácido betalámico $(10)$ & $0.88 \pm 0.02$ & $0.84 \pm 0.01$ & $1.23 \pm 0.03$ & $3.63 \pm 0.06$ \\
\hline
\end{tabular}

$a_{\text {nd: No detectado }}$

Las células en suspensión presentaron un aumento significativo en el contenido de dopamina (9) en comparación con los niveles detectados en las células cultivadas en medios semi-sólidos. Después de 8 días en cultivo en suspensión, el contenido de dopamina presente en las células fue de $42.08 \mathrm{mg}$ / g seco peso, más del doble de la cantidad 
detectada en las células del callo de la línea de color rojo (19.62 mg / g de peso seco) (Figura 31C). Las células vegetales en suspensión sufren estrés hidrodinámico debidas a la agitación continua probablemente implicando el aumento del metabolismo secundario (Hua et al., 1993; Joshi et al., 1996). El contenido de dopamina en el medio de cultivo fue menor. En este caso, la concentración máxima se encontró después de 15 días de cultivo con un contenido de $89 \mathrm{mg} / \mathrm{L}$ (Figura 31E). Aunque se conoce la presencia de dopamina en plantas de C. argentea (Schliemann et al., 2001), este es el primer informe sobre la producción de este metabolito en cultivo celular de esta especie. La producción in vitro de dopamina a través de cultivo de células vegetales transformadas con Agrobacterium rhizogenes, se reportó anteriormente para la especie Portulaca oleracea (Caryophillales), con una máxima producción de $0.90 \mathrm{mg} / \mathrm{g}$ de peso seco después de 28 días de cultivo (Ahmadi-Moghadam et al., 2014). Este valor es 40 veces menor, al obtenido en sólo 8 días en las células no transformadas de C. argentea (42.08 mg / g del peso seco).

\section{Encapsulación preliminar de betalaínas y dopamina}

Un requisito que debe cumplir todo pigmento para convertirse en colorante es ser estable (Fernández y Giménez, 2013). Con el fin de explorar la posibilidad de la estabilización de las betalaínas y la dopamina presentes en los cultivos in vitro de C. argentea var. plumosa, se realizó un estudio preliminar de encapsulación con los extractos acuosos de las líneas de callo rojo y amarillo. Para ambos casos, por separado y a una temperatura de $140^{\circ} \mathrm{C}$ del aire de entrada se llevó a cabo un proceso de secado por pulverización utilizando como matriz maltodextrina al 10 y al $20 \%$. Se obtuvieron polvos solubles en agua de color rosa y 
amarillo, correspondiéndose esta coloración al conteniendo de betacianinas y betaxantinas, respectivamente (Figura 33). La mayor pigmentación de los encapsulados se alcanzó con maltodextrina al 10 \% (Figura 33B-C y 33E-F), debido a la concentración del extracto en la matriz de encapsulación.
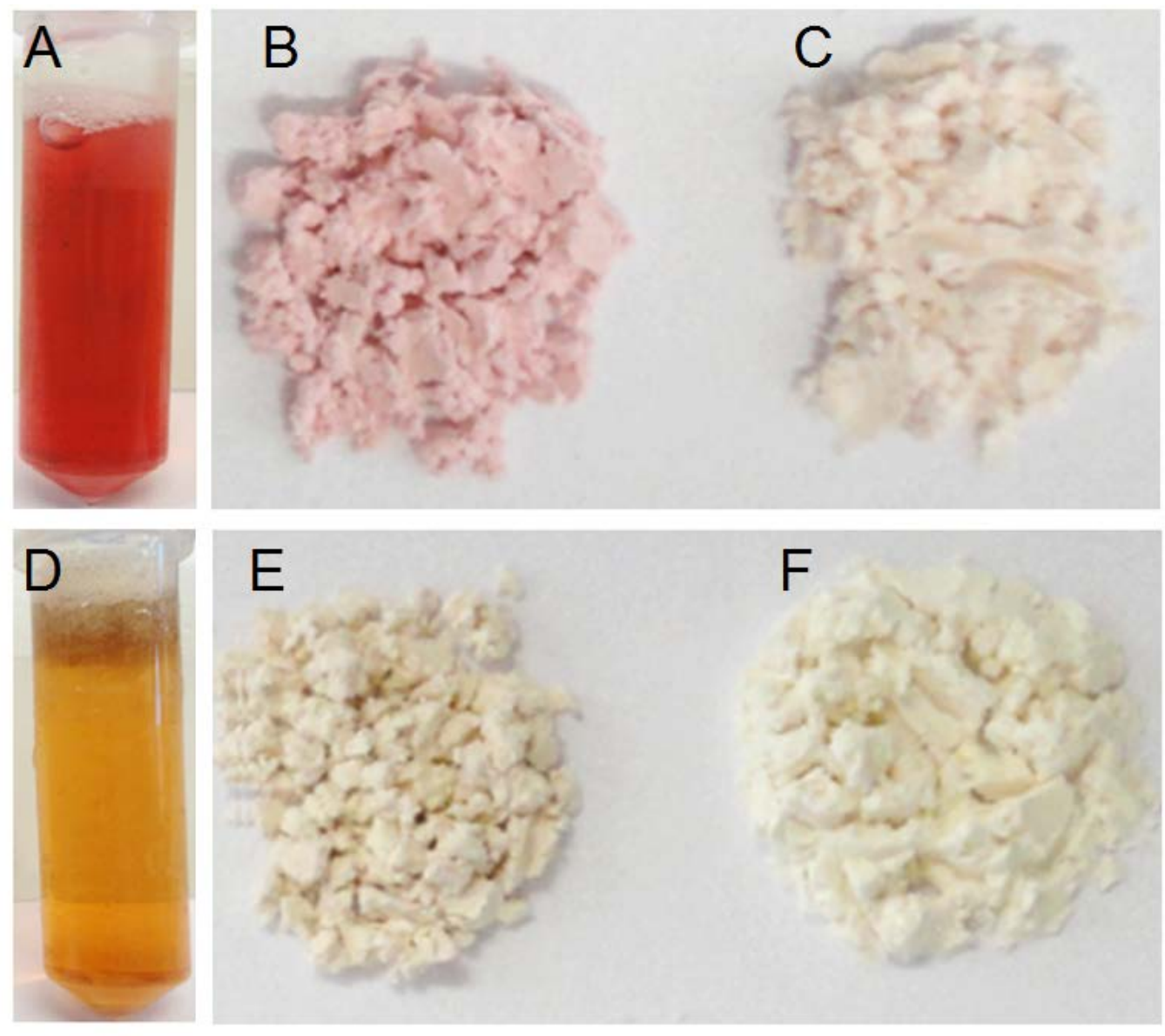

Figura 33. Encapsulados de betalaínas y dopamina de cultivos de callo de Celosía argentea. Extractos acuosos de la línea de callo rojo (A) y callo amarillo (D). Imágenes macroscópicas de los polvos resultantes de la encapsulación con maltodextrina al 10 \% (B y E) y 20 \% (C y F). 
Se espera una mayor estabilidad del pigmento encapsulado, persistencia del color, duración de la actividad antioxidante y antirradical de las betalaínas y permanencia de los compuestos bioactivos de alrededor de 6 meses; como lo reportado para indicaxantina, miraxantina $\mathrm{V}$ y betanidina, los cuales fueron encapsulados bajo condiciones equivalentes (Gandía-Herrero et al., 2010 y 2015). Por lo que estos polvos pueden ser candidatos apropiados como fuente estable de colorante para la aplicación en la industria alimentaria, cosmética y farmacéutica. 


\section{CONCLUSIONES}

1. Los cultivos de células de C. argentea, obtenidos en medio MS con $6.66 \mu \mathrm{M}$ de BAP y 6.79 $\mu \mathrm{M}$ de 2,4-D, producen dopaxantina, betanidina, miraxanthin $\mathrm{V}$ y descarboxibetanidina, para dichas betalaínas dihidroxiladas se ha reporta la más alta actividad antioxidante y antirradical.

2. Los cultivos de células de C. argentea producen triptófano-betaxantina, que ha sido identificado como un importante compuesto bioactivo de la medicina tradicional china por su posible interacción con las sirtuinas, enzimas relacionadas con el envejecimiento.

3. La presencia conjunta de compuestos bioactivos tales como betalaínas y dopamina, muestra la capacidad de las células de los cultivos de C. argentea, para convertirse en fuentes estables de valiosos fitoquímicos.

4. Extractos acuosos de la línea celular de callo rojo y callo amarillo, fueron encapsulados favorablemente con maltodextrina mediante secado por pulverización, obteniéndose polvos solubles en agua de color rosa y amarillo. Esto indica que los cultivos in vitro de $C$. argentea pueden ser fuente sostenible de compuestos bioactivos con posible aplicación como colorantes naturales. 
Capítulo 7. CONCLUSIÓN GENERAL 


\section{CONCLUSIÓN GENERAL}

En esta investigación se logró establecer cultivos in vitro de A. hypochondiacus var. nutrisol y de C. argentea var. plumosa, productores de betalaínas, ácido betalámico y en el caso de celosía, dopamina (Figura 34). Los cultivos celulares de ambas especies de amarantáceas, fueron obtenidos utilizando medio MS con $6.66 \mu \mathrm{M}$ de BAP y $6.79 \mu \mathrm{M}$ de 2,4-D, bajo las mismas condiciones de cultivo. Como fuente de explantes se ocuparon hojas e hipocótilos de amaranto y celosía, respectivamente. Con amaranto se obtuvo una línea de callo de color amarillo verdoso, del cual derivó una línea en suspensión y biorreactor de 3L, la cual no acumuló betalaínas. La producción de pigmentos se logró, por estimulación mediante estrés abiótico y la adición de sustratos al medio de cultivo. Con celosía, se obtuvieron dos líneas celulares de callo color amarillo y rojo, con este último se estableció una línea en suspensión celular productora de betalaínas. En amaranto, la acumulación máxima de betalaínas (18.07 mg/ g de peso seco) se alcanzó en los cultivos en suspensión suplementados con 1.5 mM de L-DOPA, ocho días posteriores a la inoculación. En celosía el máximo de betalaínas (14.71 mg/g de peso seco) se logró en suspensiones celulares, a los 8 días de cultivo, sin la adición de intermediarios biosintéticos en el medio de cultivo. Los extractos acuosos de callo rojo y callo amarillo de celosía, se encapsularon con maltodextrina al $10 \%$, obteniéndose polvos solubles en agua de color rosa y amarillo. Los resultados obtenidos revelan el potencial de los cultivos celulares de estas dos especies para la obtención de compuestos nutracéuticos, con posible aplicación como colorantes naturales en la industria alimentaria, farmacéutica y cosmética. 
<smiles>O=C(O)C1=C/C(=C/C=N[C@@H](Cc2ccc(O)c(O)c2)C(=O)O)C[C@H](C(=O)O)N1</smiles><smiles>NC(=O)CC[C@H](N=C/C=C1\C=C(C(=O)O)N[C@H](C(=O)O)C1)C(=O)O</smiles><smiles>O=C(O)C1=C/C(=C/C=NCCc2ccc(O)c(O)c2)C[C@@H](C(=O)O)N1</smiles><smiles>O=C(O)C1=C/C(=C/C=N\[C@@H](Cc2c[nH]c3ccccc23)C(=O)O)C[C@@H](C(=O)O)N1</smiles><smiles></smiles>

3<smiles>NCCc1ccc(O)c(O)c1</smiles>

9<smiles>O=C(O)C1=C/C(=C/C=[N+]2CCc3cc(O)c(O)cc32)C[C@@H](C(=O)O)N1</smiles>

4<smiles>O=C/C=C1\C=C(C(=O)O)N[C@H](C(=O)O)C1</smiles>

10<smiles>CC1OC(O)C(O)C(O)C1O</smiles><smiles>COC1=CCCC=C1O</smiles><smiles>C=C1C=C(C(=O)O)N[C@H](C(=O)O)C1</smiles>

7

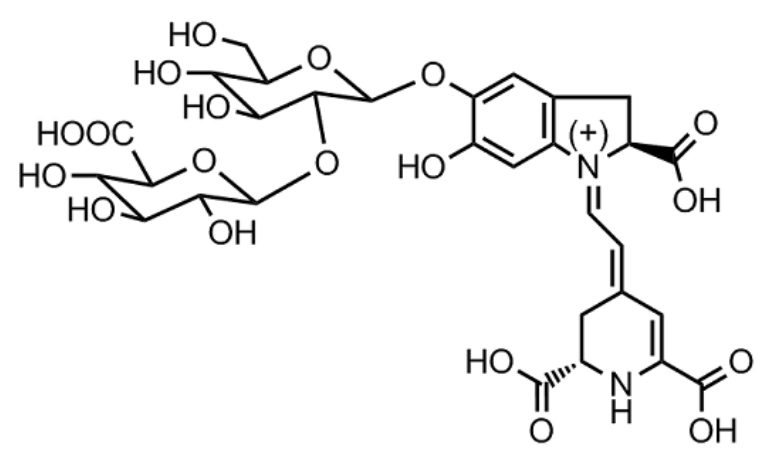

8

Figura 34. Estructuras de betalaínas obtenidas en cultivos in vitro de A. hypochondriacus y C. argentea. Dopaxantina (1), miraxantina V (2), betanidina (3), y descarboxi-betanidina (4), vulgaxantina I (5) y triptófano-betaxantina (6), betanina (7) y amarantina (8). También se muestran las moléculas precursoras dopamina (9) y ácido betalámico (10). 
Capítulo 8. PERSPECTIVAS 


\section{PERSPECTIVAS}

Determinar la estructura química de los pigmentos amarillos presentes en las líneas celulares de callo y suspensiones de Amaranthus hypochondriacus.

Utilizar diferentes factores de estrés y la biotransformación de sustratos, como estrategia de estimulación para incrementar la sobreproducción de betalaínas, en las líneas celulares in vitro de A. hypochondriacus y C. argentea.

Escalar a biorreactor la producción de betalaínas en las líneas celulares in vitro de $A$. hypochondriacus y C. argentea.

Evaluar las diferencias genéticas, bioquímicas y fisiológicas de las líneas celulares en suspensión de A. hypochondriacus y C. argentea, que producen las más altas concentraciones de betalaínas; para aclarar cómo actúan los diversos factores de estrés implicados en la activación de la ruta biosintética de betalaínas.

Evaluar la estabilidad de encapsulación y la estabilidad de las betalaínas encapsuladas de los extractos acuosos de C. argentea. 
Continuar los estudios de encapsulación de los compuestos nutracéuticos acumulados en los cultivos celulares de estas dos Caryophyllales.

Aplicar nuevas herramientas biotecnológicas encaminadas no sólo a la producción de betalaínas; sino también a la obtención de otros metabolitos secundarios de interés, tales como compuestos fenólicos y ácidos hidroxicinámicos en A. hypochondriacus var. nutrisol y C. argentea var. plumosa. 
Capítulo 9. BIBLIOGRAFÍA 


\section{BIBLIOGRAFÍA}

Abu-Romman, S. The influence of plant growth regulators on callus induction from hypocotyls of cucumber (Cucumis sativus L.). Adv. Environ. Biol. 2013, 7, 339-343.

Ahmadi-Moghadam, Y.; Piri, K.; Bahramnejad, B.; Ghiasvand, T. Dopamine production in hairy root cultures of Portulaca oleracea (purslane) using Agrobacterium rhizogenes. J. Agric. Sci. Technol. 2014, 16, 409-420.

Ahmad, I.; Dole J. M. Optimal postharvest handling protocols for Celosia argentea var. cristata L. 'Fire Chief' and Antirrhinum majus L. 'Chantilly Yellow'. Scientia Horticulturae. 2014, 172, 308-316.

Akita, T.; Hina, Y.; Nishi, T. Production of betacyanins by a cell suspension culture of table beet (Beta vulgaris L.). Biosci Biotech Biochem. 2000, 64, 1807-1812.

Alard, D; Wray, V.; Grotjahn, L.; Reznik, H.; Strack, D. Neobetanin: Isolation and identification from Beta vulgaris. Phytochemestry, 1985, 24, 2383-2385.

Alejandre-Iturbide, G.; Gómez-Lorence, F. Cultivo del amaranto en México. Colección Cuadernos Universitarios. Serie Agronomía No. 12. Universidad Autónoma Chapingo. 1986, 245.

Allegra, M.; Furtmüller, p. G.; Jantsscko, w.; Zederbauer, M.; Tesoriere, L.; Livrea, M. A.; Obinger, C. mechanism of interaction of betanin and indicaxanthin with human myeloperoxidase and hypochlorous acid. Biochem. Biophys. Res. Commun. 2005, 332, 837-844.

Amin, I.; Norazaidah, Y.; Hainida, K. I. E. Antioxidant activity and phenolic content of raw and blanched Amaranthus species. Food Chem. 2006, 94, 47-52.

APG II. An Update of the Angiosperm Phylogeny Group Classification for the orders and families of flowering plants. Botanical Journal of the Linnean Society. 2003. 141, 399-436

Baenas, N.; García-Viguera C.; Moreno, D. A. Elicitation: A Tool for Enriching the Bioactive Composition of Foods. Molecules. 2014, 19, 13541-13563.

Berlin, J.; Sieg, S.; Strack, D.; Bokern, M.; Harms, H. Production of betalains by suspension cultures of Chenopodium rubrum L. Plant Cell Tiss Org Cult. 1986, 5, 163-174. 
Bianco-Colomas, J. Qualitative and quantitative aspects of betalains biosynthesis in Amaranthus caudatus L. var pendula seedlings. Planta. 1980. 149:176-180.

Biswas, M.; Sekhar-Das, S.; Dey, S. Establishment of a Stable Amaranthus tricolor Callus Line for Production of Food Colorant. Food Sci. Biotechnol. 2013, 22(S): 1-8.

Böhm, H.; Böhm, L.; Rink, E.; Establishment and characterization of a betaxanthinproducing cell culture from Portulaca grandiflora. Plant Cell Tiss Org Cult. 1991, 26, 7582.

Buchanan, B. B.; Gruissem, W.; Jones, R. L. Biochemistry and Molecular Biology of Plants. American Society of Plants Physiologists, Maryland USA. 2000.

Butera, D.; Tesoriere, L.; Di Gaudio, F.; Bongiorno, A.; Allegra, M.; Pintaudi, A. M.; Kohen, R.; Livrea, M. A. Antioxidant activities of sicilian prickly pear (Opuntia ficus indica) fruit extracts and reducing properties of its betalains: Betanin and indicaxanthin. J. Agric. Food Chem. 2002, 50, 6895-6901.

Bhuiyan, N. H.; Adachi, T.Stimulation of betacyanin synthesis through exogenous methyl jasmonate and other elicitors in suspension-cultured cells of Portulaca. J Plant Physiol. 2003, 160, 1117-1124.

Brockington, S. F.; Walker, R. H.; Glover, B. J.; Soltis, P.S.; Soltis, D. E. Complex pigment evolution in the Caryophyllales. New Phytologist. 2011, 190, 854-864.

Brockington, S. F.; Yang, Y.; Gandia-Herrero, F.; Covshoff, S.; Hibberd, J. H.; Sage, R. F.; Wong, G. K; Moore, M. J.; Smith, S. A. Lineage-specific gene radiations underlie the evolution of novel betalain pigmentation in Caryophyllales. New Phytologist. 2015. En prensa.

Cabanes, J.; García-Cánovas, F.; Lozano, J. A.; García-Carmona, F. A kinetic study of the melanization pathway between L-tyrosine and dopachrome. Biochim. Biophys. 1987, 923, 187-195.

Cabanes, J.; Chazarra, S.; Garcia-Carmona, F. Tyrosinase kinetics: a semi-quantitative model of the mechanism of oxidation of monohydric and dihydric phenolic substrates reply. J. Theor. Biol. 2002, 214, 321-325.

Cardoza, V. Tissue culture: The manipulation of plant development. En: Plant biotechnology and genetic: principles, techniques, and applications. CN Stewart Jr (Ed). John Wiley and Sons, Inc. Knoxville, Tennessee. 2008, 113-134.

Carmona, I. De colorantes sintéticos a naturales en la industria alimentaria. Agrimundo. Reporte 5. Alimentos Procesados. ODEPA. 2013, 26-31. 
Castellar, M. R.; Obón, J. M.; Alacid, M.; Fernádez-López. J. A. (2008) Fermentation of Opuntia stricta (Haw.) Fruits for Betalains Concentration. J. Agric. Food Chem., 56, 42534257.

Cai, Y. Z.; Corke, H. Amaranthus betacyanin pigments applied in model food systems. J. Agric. Food Chem. 1999, 64, 869-873.

Cai, Y. Z.; Sun, M.; Schliemann,W.; Corke, H. Chemical Stability and Colorant Properties of Betaxanthin Pigment from Celosia angentea. J. Agric. Food Chem. 2001, 49, 44294435.

Cai, Y.; Sun, M.; Corke, H. Antioxidant activity of betalains from plants of the Amaranthaceae. J. Agric. Food Chem. 2003, 51, 2288-2294.

Cai, Y.Z.; Sun, M.; Corke, H. Characterization and application of betalain pigments from plants of the Amaranthaceae. Trends Food Sci. Technol. 2005, 16, 370-376.

Casique-Arroyo, G.; Martínez-Gallardo, N.; González de la Vara, Luis.; Délano-Frier, J.P. Betacyanin Biosynthetic Genes and Enzymes Are Differentially Induced by (a)biotic Stress in Amaranthus Hypochondriacus. PLOS ONE. 2014, 9(6), 99012.

CONABIO. Catálogo taxonómico de especies de México. 1. In Capital Nat. México. 2009, 196-199.

Chapman, E. J.; Greenham K.; Castillejo, C.; Sartor, R.; Bialy, A. Hypocotyl transcriptome reveals auxin regulation of growth-promoting genes through ga-dependent and independent pathways. PLoS One 2012, 7, 10.1371/journal.pone.0036210.

Chen, K.-C.; Jian, Y.-R.; Sun, M.-F.; Chang, T.-T.; Lee, C.-C.; Chen, C. Y.-C. Investigation of silent information regulator 1 (Sirt1) agonists from traditional Chinese medicine. J. Biomol. Struct. Dyn. 2013, 31, 1207-1218.

Christinet, L.; Burdet, F. X.; Zaiko, M.; Hinz, U.; Zrÿd, J. P. Characterization and functional identification of a novel plant 4,5-extradiol dioxygenase involved in betalain pigment biosynthesis in Portulaca grandiflora. Plant Physiol. 2004, 134: 265-274.

del Campo, N.; Chamberlain, S. R.; Sahakian, B. J.; Robbins, T. W. The roles of dopamine and noradrenaline in the pathophysiology and treatment of attention-deficit/hyperactivity disorder. Biol. Psychiatry 2011, 69, E145-E157.

Downham, A.; Collins, P. Colouring our foods in the last and next millennium. International Journal of Food Science and Technology. 2000, 35, 5-22. 
Dulce, M., Jiménez-Aguilar, Mújica-Paz, H., Welti-Chanes, J. Phytochemical Characterization of Prickly Pear (Opuntia spp.) and of its Nutritional and Functional Properties: A Review. Current Nutrition \& Food Science. 2014, 10, 57-69.

Dunlop, B. W.; Nemeroff, C. B. The role of dopamine in the pathophysiology of depression. Arch. Gen. Psychiatry 2007, 64, 327-337.

Elliot, D. C. Ionic regulation for citokinin-dependent betacyanin synthesis in Amaranthus seedlings. Plant Physiol. 1975, 63, 264-268.

Espitia-Rangel E. Estabilidad del rendimiento en amaranto, en Primer Congreso Internacional del Amaranto, Oaxtepec, Mor. México. 1991, 22(27), 65.

Fennema, O.R.; Química de los alimentos. Segunda edición. Editorial Acribia, Zaragoza, España. 1995. Capítulo 10, 773-849.

Fernández-López, J. A.; Giménez, P. J. Betalaínas: colorantes naturales bioactivos. Investigación y Ciencia, ISSN 0210-136X. 2013 , 445, 10-12

Fifel, K.; Cooper, H. M. Loss of dopamine disrupts circadian rhythms in a mouse model of Parkinson's disease. Neurobiol. Dis. 2014, 71, 359-369.

Fischer, N.; Dreiding, A.S. Biosynthesis of betalaines. On the cleavage of the aromatic ring during the enzymatic transformation of dopa into betalamic acid. Helv. Chim. 1972, 55, 649-658.

Gamborg, O.L.; Miller, R.A.; Ojima, K. Nutrient requirements of suspension cultures of soybean root cells. Experimental Cell Research.1968. 50,151-158.

Gandía-Herrero, F.; García-Carmona, F.; Escribano, J. Purification and characterization of a latent polyphenol oxidase from beet root (Beta vulgaris L.). J. Agric. Food Chem. 2004, 52, 609-615.

Gandía-Herrero, F.; García-Carmona, F.; Escribano, J. Floral fluorescence effect. Nature 2005a, 437, 334-334.

Gandía-Herrero, F.; García-Carmona, F.; Escribano, J. A novel method using highperformance liquid chromatography with fluorescence detection for the determination of betaxanthins. J. Chromatogr. A 2005b, 1078, 83-89.

Gandía-Herrero, F.; García-Carmona, F.; Escribano, J. Development of a protocol for the semi-synthesis and purification of betaxanthins. Phytochem. Anal. 2006, 17, 262-269. 
Gandía-Herrero, F.; Escribano, J.; García-Carmona, F. Characterization of the activity of tyrosinase on betanidin. J. Agric. Food Chem. 2007, 55, 1546-1551

Gandía-Herrero, F.; Escribano, J.; García-Carmona, F. The role of phenolic hydroxy groups in the free radical scavenging activity of betalains. J. Nat. Prod. 2009, 72, 1142-1146.

Gandía-Herrero, F.; Escribano, J.; García-Carmona, F. Structural implications on color, fluorescence, and antiradical activity in betalains. Planta. 2010, 232, 449-460.

Gandía-Herrero, F.; Escribano, J.; García-Carmona, F. Purification and antiradical properties of the structural unit of betalains. J. Nat. Prod. 2012, 75, 1030-1036.

Gandía-Herrero, F.; García-Carmona, F. Biosynthesis of betalains: yellow and violet plant pigments. Trends Plant Sci. 2013, 18, 334-343.

Gandía-Herrero, F.; Cabanes, J.; Escribano, J.; García-Carmona, F.; Jiménez-Atiénzar, M. Encapsulation of the most potent antioxidant betalains in edible matrixes as powders of different colors. J. Agric. Food Chem. 2013b, 61, 4294-4302.

Gandía-Herrero, F.; Escribano, J.; García-Carmona, F. Biological activities of plant pigments betalains. Crit. Rev. Food Sci. Nutr. 2015, DOI: 10.1080/10408398.2012.740103.

García-Carmona, F.; Gandía-Herrero, F.; Escribano, J. Flores Fluorescentes.Investigación y Ciencia. 2011, 50-57.

Gao, Z. J.; Han, X.H.; Xiao, X.G. Purification and characterisation of polyphenol oxidase from red Swiss chard (Beta vulgaris subspecies cicla) leaves. Food Chem. 2009, 117, 342348.

Georgiev, V.; Ilieva, M.; Bley, T.; Pavlov, A. Betalain production in plant in vitro systems. Acta Physiol Plant, 2008. DOI: 10.1007/s11738-008-0170-6.

Gil, A. Tratado de nutrición. Medica Panamericana. 2010, 89-92.

Girod, P.A.; Zrÿd, J. P. Biogenesis of betalains: purification and partial characterization of DOPA 4,5-dioxygenase from Amanita muscaria. Phytochemistry. 1991, 30, 169-174

Gonçalves, L. C. P.; Tonelli, R. R.; Bagnaresi, P.; Mortara, R. A.; Ferreira, A. G.; Bastos, E. L. A nature-inspired betalainic probe for livecell imaging of Plasmodium-infected erythrocytes. PLoS One 2013, 8, e53874.

Godoy-Alcántar, C.; Anatoly, K.; Yatsimirsky.; Lehn, J. M. Structure-stability correlations for imine formation in aqueous solution. J. Phys. Org. Chem. 2005, 18, 979-985. 
Guengerich, F.P. Common and uncommon cytochrome P450 reactions related to metabolism and chemical toxicity. Chem. Res. Toxicol. 2001, 14, 611-650.

Gliszczyńska-Świgło, A.; Szymusiak, H.; Malinowska, P. Betanin, the main pigment of red beet: Molecular origin of its exceptionally high free radical-scavenging activity. Food Addit. Contam. 2006, 23,1079-1087.

Hadacek, F.; Bachmann, G.; Engelmeier, D.; Chobot, V. Hormesis and a chemical raison d'être for secondary plant metabolites. Dose-Response. 2011, 9 (1), 79-116.

Hancock, M.Potential for colourants from plant sources in England \& Wales. ADAS Arable Crops \& Horticulture Division, Boxworth. 1997, 4-52.

Hans, J.; Brandt, W.; Vogt, T. Site-directed mutagenesis and protein 3D-homology modeling suggest a catalytic mechanism for UDP-glucose-dependent betanidin 5-Oglucosyltransferase from Dorotheanthus bellidiformis. Plant J. 2004, 39, 319-333.

Hatlestad, G. J.; Sunnadeniya, R. M.; Akhavan, N. A.; Gonzalez, A.; Goldman, I. L. The beet $\mathrm{R}$ locus encodes a new cytochrome P450 required for red betalain production. Nat. Genet. 2012, 44, 816-820.

Hatlestad, G. J.; Akhavan, N. A.; Sunnadeniya, R. M.; Elam, L.; Cargile, S.; Hembd A.; Gonzalez A.; McGrath J. M.; Lloyd, A. M. The beet $Y$ locus encodes an anthocyanin MYB-like protein that activates the betalain red pigment pathway. Nature Genetics. 2015, 47, 92-96.

Hempel, J.; and Böhm, H. Betaxanthin pattern of hairy roots from Beta vulgaris var. lutea and its alteration by feeding of amino acids. Phytochemistry. 1997, 44, 847-852

Henriette, M. C.; Azeredo. Betalains: properties, sources, applications, and stability - a review. International Journal of Food Science and Technology 2009, 44, 2365-2376.

Heuer, S.; Wray,V.; Metzger, J.W.; Strack, D. Betacyanins from flowers of Gomphrena globosa. Phytochemistry. 1992, 31: 1801-1807.

Heuer, S.; Vogt,T.; Boehm, H.; Strack, D. Partial purification and characterization of UDPglucose:betanidin 5-O- and 6-O-glucosyltransferases from cell suspension cultures of Dorotheanthus bellidiformis (Burm. f.) N.E.Br. Planta. 1996, 199, 244-250.

Hua, J.; Erickson, E.; Yiin, T. Y.; Glasgow, L. A review of the effects of shear and interfacial phenomena on cell viability. Crit. Rev. Biotechnol. 1993, 13, 305-328.

Huang; Hwang, L. S. Studies on the red pigment of A. tricolor. Separationand identification of the red pigment by HPLC. Shih P'in K’o Hsueh. 1981, 8(1-2), 13-25. 
Ibrahim, B.; Sowemimo, A.; van Rooyen, A.; Van de Venter, M. Antiinflammatory, analgesic and antioxidant activities of Cyathula prostrate (Linn.) Blume (Amaranthaceae). J. Ethnopharmacol. 2012, 141, 282-289.

Impellizzeri, G.; Piattelli, M.; Sciuto, S. A new betaxanthin from Glottiphyllum longum. Phytochemistry 1973, 12, 2293-2294.

Jamilah, S. Y.; Azani, S.; Hashimah, E.; Sakinah, A.; Noraini, M.; Normadiha, M. In vitro regeneration and acclimatization protocols of selected ornamental plants (Agapanthus praecox, Justicia betonica and Celosia cristata). Sains Malays. 2014, 43, 715-722.

Jimenez-Aparicio, F; Gutierrez-Lopez, G. Production of food related colorants by culture of plant cells. The case of betalains. Adv Exp Med Biol. 1999, 464, 195-210.

Jiratanan, T.; Liu, R. H. Antioxidant activity of processed table beets (Beta vulgaris var, conditiva) and green beans (Phaseolus vulgaris L.). J. Agric. Food Chem. 2004, 52, 26592670.

Joshi, J. B.; Elias, C. B.; Patole, M. S. Role of hydrodynamic shear in cultivation of animal, plant and microbial cells. Chem. Eng. J. 1996, 62, 121-141.

Judd, W. S.; Campbell, C. S.; Kellogg, E. A.; Stevens, P. F.; Donoghue, M. J. Plant Systematics: A phylogenetic approach. 3 Edition. Sinauer Associates, Sunderland, Massachusetts, USA. 2007, 189-196.

Junqueira-Gonçalves, M. P.; Zuñiga, G. E.; Zárate, H.; Arcos, K.; Ganga, A.; Miltz, J. Irradiated beetroot extract as a colorant for cream cheese. International Journal of Food Science and Technology. 2012; 47(11). DOI: 10.1111/j.1365-2621.2012.03120.x.

Kapadia, G. J.; Azuine, M. A.; Sridhar, R.; Okuda, Y.; Tsuruta, A.; Ichiishi, E.; Mukainake, T.; Takasaki, M.; Konoshima, T.; Nishino, H.; Tokuda, H. Chemoprevention of DMBAinduced UV-B promoted, NOR-1-induced TPA promoted skin carcinogenesis, and DENinduced phenobarbital promoted liver tumors in mice by extract of beetroot. Pharmacol. Res. 2003, 47, 141-148.

Kishima, Y.; Shimaya, A.; Adachi, T. Evidence that blue light induces betalain pigmentation in Portulaca callas. Plant Cell Tiss Org Cult. 1995, 43:67-70.

Kobayashi, N.; Schmidt, J.; Wray, V.; Schliemann, W. Formation and occurrence of dopamine-derived betacyanins. Phytochemistry. 2001, 56, 429-436.

Kugler, F.; Stintzing, F. C.; Carle, R. Identification of betalains from petioles of differently colored Swiss chard (Beta vulgaris L. ssp. cicla [L.] alef. cv. bright lights) by high- 
performance liquid chromatography-electrospray ionization mass spectrometry. J. Agric. Food Chem. 2004, 52, 2975-2981.

Khan, M. I.; Harsha, P. S. C. S.; Giridhar, P.; Ravishankar, G. A. Pigment identification, nutritional composition, bioactivity, and in vitro cancer cell cytotoxicity of Rivina humilis L. berries, potential source of betalains. LWT-Food Sci. Technol. 2012, 47, 315-323.

Li, J.; Christensen, B.M. Identification of products and intermediates during L-DOPA oxidation to dopachrome using highperformance liquid chromatography with electrochemical detection. J. Liq. Chromatogr. 1993, 16, 1117-1133.

Liebisch, H.W.; Matschiner, B.; Schütte, H. R. Beiträge zur Physiologie und Biosynthese des Betanins. Z. Pflanzenphysiol. 1969, 61, 269-278

Lechner, J. F.; Wang, L. S.; Rocha, C. M.; Larue, B.; Henry, C.; McIntyre, C. M.; Riedl, K. M.; Schwartz, S. J.; Stoner, G. D. Drinking water with red beetroot food color antagonizes esophageal carcinogenesis in N-nitrosomethylbenzylamine-treated rats. J. Med. Food. 2010, 13, 733-739.

Lu, X.; Wang, Y.; Zhang, Z. Radioprotective activity of betalains from red beets in mice exposed to gamma irradiation. Eur. J. Pharmacol. 2009, 615, 223-227.

Mapes, C. J.; Caballero, E.; Espitia, R. Bye. Morphophysiological variation in some Mexican species of vegetable Amaranthus: evolutionary tendencies under domestication. Genetic Resources and Crop Evolution. 1996, 43 (3), 283-290.

Martínez-Parra, J.; Muñoz, R. Characterization of betacyanin oxidation catalyzed by a peroxidase from Beta vulgaris L. roots. J. Agric. Food Chem. 2001, 49, 4064-4068.

Martinez, R. M.; Longhi-Balbinot, D. T.; Zarpelon, A. C.; Staurengo-Ferrari, L.; Baracat, M. M.; Georgetti, S. R.; Sassonia, R. C.; Verri, W. A., Jr.; Casagrande, R. Anti inflammatory activity of betalainrich dye of Beta vulgaris: effect on edema, leukocyte recruitment, superoxide anion and cytokine production. Arch. Pharmacal Res. 2014, DOI: 10.1007/s12272-014-0473-7.

Meeta, S.; Arun, K.; Hariharan.; Soumya, N.; Saurabh, G.; Suran, R.; Nambisan.; Ravi , P.; Binay, P.; Bibha, C.; Subhashini, S. The Draft Genome And Transcriptome Of Amaranthus Hypochondriacus: A C4 Dicot Producing High-Lysine Edible Pseudo-Cereal. Dna Research. 2014, 21, 585-602.

Miao, G. P.; Zhu, C.S.; Feng, J.T.; Han, L.R.; Zhang, X. Effects of Plant Stress Signal Molecules on the Production of Wilforgine in an Endophytic Actinomycete Isolated from Tripterygium wilfordii Hook. Current Microbiology. 2014. En prensa. 
Mihai, R.; Mitoi, M.; Brezeanu, A.; Cogalniceanu, G. Two-stage system, a possible strategy for the enhancement of anthocyanin biosynthesis in a long-term grape callus cultures. Romanian Biotechnological Letters. 2010, 15 (1), 5025-5033.

Moreno, D. A.; García-Viguera, C.; Gil, J. I.; Gil-Izquierdo, A. Betalains in the era of global agri-food science, technology and nutritional health. Phytochem. Rev. 2008, 7, 261280.

Mueller, L.A.; Hinz, U.; Zrÿd. J. P. Characterization of a tyrosinase from Amanita muscaria involved in betalain biosynthesis. Phytochemistry. 1996, 42, 1511-1515.

Mueller, L. A.; Hinz,U.; Uze, M.; Sautter, C.; Zrÿd, J. P. The formation of betalamic acid and muscaflavin by recombinant DOPA-dioxygenase from Amanita. Phytochemistry. 1997, 44, 567-569.

Mukundan, U.; Bhide, V.; Dawda, H. Production of betalains by hairy root cultures of Beta vulgaris L. In: Fu TJ, Singh G, Curtis WR (eds) Plant cell and tissue culture for the production of food ingradients. Kluwer Academic/Plenum Publishers, 1999, 121-127.

Müller, K.; Borsch, T. Phylogenetics of Amaranthaceae Based on matK/trnK sequence data: evidence from Parsimony, Likelihood, and Bayesian analyses. Ann. Missouri Bot. Gard. 2005, 92, 66-102.

Murashige, T.; Skoog, F. A revised medium for rapid growth and bioassays with tobacco tissue cultures. Physiol. Plant. 1962, 15, 473-97.

Musso, H. Pigments of fly agaric, Amanita muscaria. Tetrahedron.1979, 35, 2843-2853.

McCann, D.; Barrett, A.; Cooper, A.; Crumpler, D.; Dalen, L.; Grimshaw, K.; Kitchin, E.;Lok, K.; Porteous, L.; Prince, E.; Sonuga-Barke, E.; O-Warner, J.; Stevenson, J. Food additives and hyperactive behaviour in 3-year-old and 8/9-year-old children in the community: a randomised, double-blinded, placebo-controlled trial. The Lancet. 2007, 370, 1560-1567.

Pavlov, A.; Kovatcheva, P.; Georgiev, V.; Koleva, I.; Ileva M. Biosynthesis and radical scavenging activity of betalains during the cultivation of red beet (Beta vulgaris) hairy root cultures. Z. Naturforsch. 2002, 57c, 640-644.

Pedersen, T. M. Amaranthaceae, Caryophyllaceae. In A. Burkart.In A. Burkart Fl. Il. Entre Ríos. Instituto Nacional de Tecnología Agropecuaria. 1987, 3: 160-203.

Pedreño, M. A.; Escribano, J. Correlation between antiradical activity and stability of betanine from Beta vulgaris L roots under different $\mathrm{pH}$, temperature and light conditions. J. Sci. Food Agric. 2001, 81, 627-631. 
Petersen, M. Arabidopsis Map kinase 4 negatively regulates systemic acquired resistance. Cell. 2000, 103, 1111-1120.

Piattelli, M.; Minale, L.; Prota, G. Isolation, structure and absolute configuration of indicaxanthin. Tetrahedron. 1964, 20, 2325-2329.

Piattelli, M.; Minale, L.; Nicolaus, R. A. Betaxanthins from Mirabilis jalapa L. Phytochemistry 1965, 4, 817-823.

Piattelli, M.; Impellizzeri, G. 2-Descarboxybetanidin, a minor betacyanin from Carpobrothus acinaciformis. Phytochemistry 1970, 9, 2553-2556.

Piattelli, M. The betalains: structure, biosynthesis, and chemical taxonomy. In EE Conn, ed, The Biochemistry of Plants, 1981, 7,557-575

Priya, K.S.; Arumugam, G.; Rathinam, B. Celosia argentea Linn. leaf extract improves wound healing in a rat burn wound model. Wound Repair Regen. 2004, 12(6), 618-625.

Qui, J. A.; Castro-Concha, L. A.; García-Sosa, K.; Peña-Rodríguez, L. M.; Miranda-Ham, M. L. Differential effects of phytotoxic metabolites from Alternaria tagetica on Tagetes erecta cell cultures. J. Gen. Plant Pathol. 2009, 75, 331-339.

Radfar, M.; Sudarshana, M. S.; Niranjan,M. H. Betalains from stem callus cultures of Zaleya decandra L. N. Burm. f. - A medicinal herb. Journal of Medicinal Plants Research. 2012, 6(12), 2443-2447.

Radman, R.; Saez, T.; Bucke, C.; Keshavarz, T. Elicitation of plants and microbial cell systems. Biotechnol Appl Biochem. 2003, 37(1), 91-102.

Rahman-Mahbubu, A. H. M.; Gulshana-Ara, M, I. Taxonomy and Medicinal Uses on Amaranthaceae Family of Rajshahi, Bangladesh. Applied Ecology and Environmental Sciences. 2014, 2(2), 54-59.

Ramesh, B.; Nidavani.; Mahalakshmi, A. M.; Mallappa, S. Towards a better understanding of an updated ethnopharmacology of Celosia argentea L. International Journal of Pharmacy and Pharmaceutical Sciences. 2013, 5(3), 0975-1491.

Rao, S.R.; Ravishankar, G. A. Plant cell cultures: chemical factories of secondary metabolites. Biotechnol Adv. 2002, 20:101-153

Ravichandran, K.; Palaniraj, R.; Thaw, Saw.; Ahmed M. G.; Ahmed R.; Knorr, D.; Smetanska, I.; Effects of different encapsulation agents and drying process on stability of betalains extract. J Food Sci Technol. 2014, 51(9):2216-2221. 
Rice-Evans, C. A.; Miller, N. J.; Paganda, G. Structureantioxidant activity relationships of flavonoids and phenolic acids. Free Radical Biol. Med. 1996, 20, 933-956.

Robert, P.; Torres, V.; García, P.; Vergara, C.; Sáenz, C. The encapsulation of purple cactus pear (Opuntia ficus-indica) pulp by using polysaccharide-proteins as encapsulating agents. Food Science and Technology. 2015, 60, 1039-1045.

Rodríguez-Monroy, M.; Jiménez-Aparicio, A.; Dávila-Ortíz, G.; Sepúlveda-Jiménez, G. Effect of carbon source on cell growth and betalain production in cell suspension culture of Beta vulgaris. Biotechnol Lett. 1994, 16, 853-858.

Rodríguez-Monroy, M.; Galindo, E. Broth rheology, growth and metabolite production of Beta vulgaris suspension culture: a comparative study between cultures grown in shake flasks and in stirred tank. Enzyme Microb. Technol. 1999, 24, 687-693.

Rudat, A.; Göring, H. Induction of betacyanin formation in cell cultures of Chenopodium album under UV-light irradiation. J Exp Bot. 1995, 46:129-134.

Sang-Uk, C.; Buk-Gu, H.; Yong-Seo, P.; Dong-Kwan, K.; Shela, G. Total phenolics level, antioxidant activities and cytotoxicity of young sprouts of some traditional Korean salad plants. Plant Foods Hum. Nutr. 2009, 64, 25-31.

Santos-Díaz, M.S.; Velásquez-García, Y.; González-Chávez, M. M. Pigment production by callus of Mammillaria candida Scheidweiler (Cactaceae). Agrociencia. 2005, 39, 619-626

Sasaki, N.; Abe, Y.; Wada, K.; Koda, T.; Goda, Y.; Adachi, T. Detection of UDP-glucose: cyclo-DOPA 5-Oglucosyltransferase activity in four o'clocks (Mirabilis jalapa L.). FEBS Lett. 2004, 568, 159-162

Sasaki, N.; Adachi, T.; Koda, T.; Ozeki, Y. Isolation and characterization of cDNAs encoding an enzyme with glucosyltransferase activity for cyclo-DOPA from four o'clocks and feather cockscombs. Plant Cell Physiol. 2005, 46, 666-670.

Sasaki, N.; Abe, Y.; Wada, K.; Koda, T.; Goda, Y.; Adachi, T.; Ozeki, Y. Amaranthin in feather cockscombs is synthesized via glucuronylation at the cyclo-DOPA glucoside step in the betacyanin biosynthetic pathway. J. Plant Res. 2005, 118, 439-442.

Sasaki, N.; Wada, K.; Koda, T.; Kasahara, K.; Adachi, T. Amaranthin in feather cockscombs is synthesized via glucuronylation at the cyclo-DOPA glucoside step in the betacyanin biosynthetic pathway. J. Plant Res. 2005b, 118, 439-442.

Sasaki, N.; Abe, Y.; Goda, Y.; Adachi, T.; Kasahara, K. Detection of DOPA 4,5dioxygenase (DOD) activity using recombinant protein prepared from Escherichia coli cells 
harboring cDNA encoding DOD from Mirabilis jalapa. Plant Cell Physiol. 2009, 50, 10121016.

Sekiguchi, H. Ozeki, Y.; Sasaki, N. In vitro synthesis of betaxanthins using recombinant DOPA 4,5-dioxygenase and evaluation of their radicalscavenging activities. J. Agric. Food Chem. 2010, 58, 12504-12509.

Sepúlveda-Jiménez, G.; Rueda-Benítez, P.; Porta, H.; Rocha-Sosa, M.; Betacyanin synthesis in red beet (Beta vulgaris) leaves induced by wounding and bacterial infiltration is preceded by an oxidative burst. Physiological and Molecular Plant Pathology. 2004, 64 (3)125-133.

Serra-Majem, L . Guía de la alimentación funcional: Los probióticos en la alimentación humana. Elsevier Masson. 2008, 103-112.

Silva da Rocha, A.; Rocha, E. K.; Alves, L. M.; Amaral de Moraes, B.; Carvalho de Castro, T.; Albarello, N.; Simões-Gurgel, C. Production and optimization through elicitation of carotenoid pigments in the in vitro cultures of Cleome rosea Vahl (Cleomaceae). Journal of Plant Biochemistry and Biotechnology. 2013, 24 (1), 105-113.

Silva, L. R.; Valentão, P.; Faria, J.; Ferreres, F.; Sousa, C.; Gil-Izquierdo, A.; Pinho, B. R.; Andrade, P. B. Phytochemical investigations and biological potential screening with cellular and non-cellular models of globe amaranth (Gomphrena globosa L.) inflorescences. Food Chem. 2012, 135, 756-763.

Silva, N. C.; Macedo, A. F.; Lage, C. L.; Esquibel, M. A.; Sato, A. Developmental effects of additional ultraviolet A radiation, growth regulators and tyrosine in Alternanthera brasiliana (L.) Kuntze cultured in vitro. Braz Arc Biol Technol. 2005, 48:779-786.

Suresh, B.; Thimmaraju, R.; Bhagyalakshmi, N.; Ravishankar, G. A. Polyamine and methyl jasmonate-induced enhancement of betalaine production in hairy root cultures of Beta vulgaris grown in bubble column reactor and studies on efflux of pigments. Process Biochem. 2004, 39, 2091-2096.

Schliemann, W.; Kobayashi, N.; Strack, D. The decisive step in betaxanthin biosynthesis is a spontaneous reaction. Plant Physiol. 1999, 119, 1217-1232.

Schliemann, W.; Cai, Y.; Degenkolb, T.; Schmidt, J.; Corke, H. Betalains of Celosia argentea. Phytochemistry. 2001, 58, 159-165.

Schwartz, S. J.; von Elbe, J. H. Quantitative determination of individual betacyanin pigments by high-performance liquid chromatography. J. Agric. Food Chem. 1980, 28, 540-543. 
Shimada, S.; Otsuki H.; Sakuta M. Transcriptional control of anthocyanin biosynthetic genes in the Caryophyllales. J. Exp. Bot. 2007, 58, 957-967.

Shin, K. S.; Murthy, H. N.; Heo, J. W.; Paek, K. Y. Induction of betalain pigmentation in hairy roots of red beet under different radiation sources. Biol Plant. 2003, 47:149-152.

Shiyi, Ou.; Kin-Chor, Kwok. Ferulic acid: pharmaceutical functions, preparation and applications in foods. Journal of the Science of Food and Agriculture. 2004. 84 (11) 12611269.

Sreekanth, D.; Arunasree, M. K.; Roy, K. R.; Reddy, T. C.; Reddy, G. V.; Reddanna, P. Betanin, a betacyanin pigment purified from fruits of Opuntia ficus-indica induces apoptosis in human chronic myeloid leukemia cell line-K562. Phytomedicine 2007, 4, 739-746.

Steiner, U.; Schliemann, W.; Böhm, H., Strack, D. Tyrosinase involved in betalain biosyntesis of higher plants. Planta 1999, 208, 114-124.

Stewart, A. J.; Mullen, W.; Crozier, A. On-line high-performance liquid chromatography analysis of the antioxidant activity of phenolic compounds in green and black tea. Mol. Nutr. Food Res. 2005, 49, 52- 60.

Stintzing, F. C.; Schieber, A.; Carle, R. Amino acid composition and betaxanthin formation in fruits from Opuntia f icus-indica. Planta Med. 1999, 65, 632-635.

Stintzing, F. C.; Carle, R. C. Functional properties of anthocyanins and betalains in plants, food, and in human nutritionTrends in Food Science \& Technology. 2004, 15, 19-38.

Strack, D.; Vogt,T.; Schliemann, W. Recent advances in betalain research. Phytochemistry. 2003, 62, 247-269.

Taha, R. M.; Wafa, S. N. Plant regeneration and cellular behaviour studies in Celosia cristata grown in vivo and in vitro. Sci. World J. 2012, DOI: 10.1100/2012/359413.

Taya, M.; Mine, K.; Kino-Oka, M.; Tone, S.; Ichi, T. Production and release of pigments by culture of transformed hairy root of red beet. J Fermen Bioeng. 1992, 73:3136.

Tesoriere, L.; Allegra, M.; Butera, D.; Livrea, M. A. Absorption, excretion, and distribution of dietary antioxidant betalains in LDLs: Potential health effects of betalains in humans. American Journal of Clinical Nutrition. 2004, 80, 941-945. 
Tesoriere, L.; Butera, D.; Allegra, M.; Fazzari, M.; and Livrea, M. A. Distribution of Betalains Pigments in Red Blood Cells After Consumption of Cactus Pear Fruits and Increased Resistance of the Cells to ex Vivo Induced Oxidative Hemolysis in Humans. J. Agric. Food Chem. 2005, 53, 1266-1270.

Trejo-Tapia, G.; Rodríguez-Monroy, M. Cellular aggregation in secondary metabolite production in in vitro plant cell cultures. Interciencia 2007, 32, 669-674.

Trezzini, G. F.; Zrÿd, J.-P. Two betalains from Portulaca grandiflora. Phytochemistry 1991, 30, 1897-1899.

Trezzini, G. F.; Zrÿd, J.-P. Characterization of some natural and semisynthetic betaxanthins. Phytochemistry 1991b, 30, 1901-1904.

Tzin, V.; Galili, G. New insights into the shikimate and aromatic amino acids biosynthesis pathways in plants. Mol. Plant. 2010. 3, 956-972

Vanisree, M.; Lee, C. Y.; Lo, S. F.; Nalawade, S. M.; Lin, C. Y.; Tsay, H. S. Studies on the production of some important secondary metabolites from medicinal plants by plant tissue cultures. Bot Bull Acad Sin. 2004, 45,1-22.

Vasu, T. S.; Cavallazzi, R.; Hirani, A.; Kaplan, G.; Leiby, B.; Marik, P. E. Norepinephrine or dopamine for septic shock: systematic review of randomized clinical trials. J. Intensive Care Med. 2012, 27, 172-178.

Vidal, P. J.; López-Nicolás, J. M.; Gandía-Herrero, F.; García- Carmona, F. Inactivation of lipoxygenase and cyclooxygenase by natural betalains and semi-synthetic analogues. Food Chem. 2014, 154, 246-254.

Villegas, R. L.; García, H. F.; Caballero, A. Y.; Santos de Flores, E. Estudio de los colorantes del betabel ( Beta vulgaris L.). Revista de la Sociedad Química de México. 1983, 27 (4), 175-183.

Wang, C. Quan.; Yang, G. Q. Betacyanins from Portulaca oleracea L. amelio rate cognition deficitsand attenuate oxidatived amage induced by D-galactose in the brains of senescent mice. Phytomedicine . 2010, 17, 527-532.

Wu, L. C.; Hsu, H. W.; Chen, Y. C.; Chiu, C. C.; Lin, Y. I.; Ho, J. A. A. Antioxidant and antiproliferative activities of red pitaya. Food Chem. 2006, 95, 319-327.

Wheeler, J. R. "Family 36 Amaranthaceae." In Flora of the Kimberley Region. J.R. Wheeler, B.L. Rye, B.L. Koch, and A.J.G. Wilson, Eds. Department of Conservation and Land Management, Como, Australia, 1992,106-33. 
Wyler, H.; Dreiding, A. S.; Darstellung und Abbauprodukte des Betanidins. Hel. Chim. Acta, 1957, 42, 1699-1702.

Wyler, H.; Chiovini, J. Die Synthese von Cyclodopa (Leukodopachrom). Helv. Chim. 1968, 51, 1476-1494.

Wybraniec, S.; Michałowski, T. New pathways of betanidin and betanin enzymatic oxidation. J. Agric. Food Chem. 2011, 59, 9612-9622.

Ying-Hua, S.; Yu-Bo, L.; Xian-Sheng, Z. Auxin-cytokinin interaction regulates meristem development. Mol. Plant 2011, 4, 616-625.

Zakharova, N. S.; Petrova, T. A. $\beta$-Glucosidases from leaves and roots of the common beet, Beta vulgaris. Appl. Biochem. Microbiol. 2000, 36, 394-397.

Zhang, M.; Curtin, C.; Franco, C.; Towards manipulation of post-biosythetic events in secondary metabolism of plant cell cultures. Enzyme and Microbial Technology. 2002, 30, 688-696.

Zhao, S. Z.; Sun, H. Z.; Gao, Y.; Sui, N.; Wang, B. S. Growth regulator-induced betacyanin accumulation and dopa-4,5-dioxygenase (DODA) gene expression in euhalophyte Suaeda salsa calli. In Vitro Cell. Dev. Biol.: Plant 2011, 47, 391-398. 
Capítulo 10. ARTÍCULO 


\title{
Production of Dihydroxylated Betalains and Dopamine in Cell Suspension Cultures of Celosia argentea var. plumosa
}

\author{
Berenice Guadarrama-Flores, ${ }^{\dagger \neq}, \S$ Mario Rodríguez-Monroy, ${ }^{\ddagger}$ Francisco Cruz-Sosa, ${ }^{\dagger}$ \\ Francisco García-Carmona, ${ }^{\S}$ and Fernando Gandía-Herrero ${ }^{*} \S$
}

\begin{abstract}
${ }^{\dagger}$ Departamento de Biotecnología, Universidad Autónoma Metropolitana-Unidad Iztapalapa, Col. Vicentina, 09340 Ciudad de México, Federal District, Mexico

${ }^{\ddagger}$ Departamento de Biotecnología, Centro de Desarrollo de Productos Bióticos (CeProBi), Instituto Politécnico Nacional, San Isidro, Yautepec, Morelos, Mexico

${ }^{\S}$ Departamento de Bioquímica y Biología Molecular A, Unidad Docente de Biología, Facultad de Veterinaria, Regional Campus of International Excellence "Campus Mare Nostrum”, Universidad de Murcia, E-30100 Espinardo, Murcia, Spain
\end{abstract}

ABSTRACT: Betalains are plant pigments of hydrophilic nature with demonstrated chemopreventive potential in cancer cell lines and animal models. Among the betalains, those containing an aromatic moiety with two free hydroxyl groups possess the strongest antioxidant and free radical scavenging activities. The betaxanthins dopaxanthin and miraxanthin $\mathrm{V}$ and the betacyanins betanidin and decarboxy-betanidin are the only natural betalains with catecholic substructures. These four pigments have been produced in cell cultures established from hypocotyls of the plant Celosia argentea. Two stable and differentially colored cell lines, yellow and red, were maintained on Murashige and Skoog medium supplemented with the plant growth regulators 6benzylaminopurine $(6.66 \mu \mathrm{M})$ and 2,4-dichlorophenoxyacetic acid $(6.79 \mu \mathrm{M})$. Derived suspension cultures showed increased production of dihydroxylated betalains in the cells and secreted to the medium with a maximum reached after 8 days of culture. In addition, precursor molecules betalamic acid and dopamine, with content up to $42.08 \mathrm{mg} / \mathrm{g}$ dry weight, were also obtained. The joint presence of the bioactive betalains together with the production of dopamine and betalamic acid show the ability of cell cultures of $C$. argentea to become a stable source of valuable phytochemicals.

KEYWORDS: antiradical, betalains, bioactive, dopamine, secondary metabolism

\section{INTRODUCTION}

Betalains are plant pigments of hydrophilic nature responsible for the bright coloration of species belonging to the order Caryophyllales where they substitute for anthocyanins. They are bioactive molecules with high antioxidant and free radical scavenging activities and have demonstrated a strong chemopreventive potential both in cancer cell lines and in vivo studies with animal models. ${ }^{1}$ Betalains are classified into two structural groups: betacyanins and betaxanthins. The violet betacyanins possess an indoline-derived moiety, and the yellow betaxanthins contain open structures derived from amines and amino acids (Figure 1). ${ }^{2}$ Among the betalains, those containing free hydroxyl groups possess the strongest antioxidant and free radical scavenging activities with Trolox equivalent antioxidant capacity (TEAC) of $4.0 \mathrm{mM}$ for those pigments with one hydroxyl group and $5.8 \mathrm{mM}$ for those containing two groups., Thus, the natural betalains with the highest antioxidant potential are the betaxanthins dopaxanthin (1) and miraxanthin $\mathrm{V}$ (2) and the betacyanins betanidin (3) and decarboxybetanidin (4) (Figure 1).

Miraxanthin V (dopamine-betaxanthin) (2) and decarboxybetanidin (4) are natural pigments derived from dopamine (9). Dopamine is a neurotransmitter involved in the reward response, a deficit that has been correlated with depression, ${ }^{5}$ Parkinson's disease, ${ }^{6}$ and attention deficit hyperactivity disorder. ${ }^{7}$ Dopamine, together with norepinephrine, is also therapeutically used in the treatment of septic shocks. ${ }^{8}$ The potential applications of these natural bioactive betalains are limited due to the reduced number of known plant sources and tools to produce them. Miraxanthin V (2) has been described in the genus Mirabilis, ${ }^{9}$ Beta $^{10}{ }^{10}$ Portulaca, ${ }^{11}$ and Celosia, ${ }^{12}$ while decarboxy-betanidin (4) has been described in the genus Carpobrotus, ${ }^{13}$ Beta $^{14}$ and Celosia. ${ }^{12}$ The carboxylated forms of the dihydroxylated betaxanthin, dopaxanthin (1), can be found in Glottiphyllum, ${ }^{15}$ Portulaca, ${ }^{11}$ and Lampranthus. ${ }^{2}$ The carboxylated betacyanin betanidin (3) can be found as a precursor of the glucosylated betanin (7) or as a pigment in Dorotheanthus bellidiformis $^{16}$ and Lampranthus productus. ${ }^{2}$ Pigment biosynthesis is exclusive of colored structures, and thus, dihydroxylated betalains production depends in most cases on the presence of flowers and their number in fully developed plants for extraction. A biotechnological approach to the production of these molecules is necessary to avoid this dependence.

In addition to their bioactive properties, the current interest in betalains is driven by their use as safe food colorants under the E-162 code in the European Union and as the additive 73.40 in the 21 CFR section of the Food and Drug Administration (FDA) in the United States. A diversification

Received: January 5, 2015

Revised: February 27, 2015

Accepted: March 1, 2015

Published: March 1, 2015 

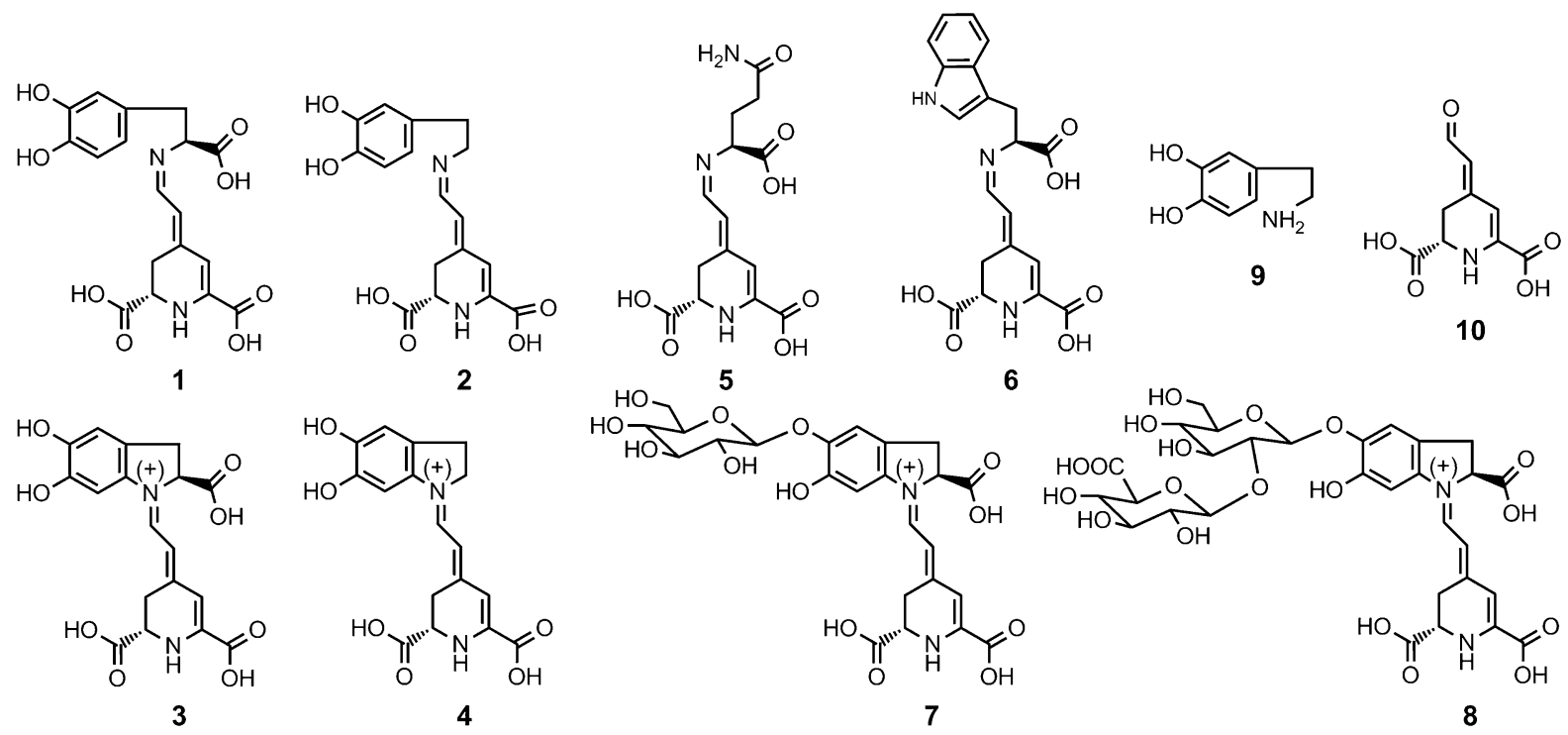

Figure 1. Structures for the dihydroxylated betalains dopaxanthin (1), miraxanthin V (2), betanidin (3), and decarboxy-betanidin (4). Structures for additional pigments obtained in this study are also shown, corresponding to the betaxanthins vulgaxanthin I (5) and tryptophan-betaxanthin (6) and the betacyanins betanin (7) and amaranthin (8). Precursor molecules dopamine (9) and betalamic acid (10) are also shown.

in the sources of betaxanthins and betacyanins may lead to different shades to be used in the coloration of foods and beverages. In this sense, some betalain-containing plants of the Amaranthaceae are consumed cooked or fresh ${ }^{17,18}$ and used in traditional medicine to alleviate the symptoms of inflammation. ${ }^{19,20}$

Dihydroxylated betalains have the potential to become bioactive constituents in foods and can be combined to generate tailor-made colors which can be encapsulated to obtain products with a shelf life of months. ${ }^{21}$ This study was designed to develop cell cultures of Celosia argentea as a model plant of the Amaranthaceae family and to explore the potential of liquid culture in the production of dihydroxylated betalains. The appearance of structurally related molecules is quantitated and discussed in terms of the biosynthetic pathway of betalains.

\section{MATERIALS AND METHODS}

Chemicals. Chemicals and reagents were purchased from Sigma (St. Louis, MO). Solvents were from Merck Chemicals Ltd. (Dorset, England). HPLC-grade acetonitrile and methanol were purchased from Labscan Ltd. (Dublin, Ireland). Distilled water was purified using a Milli-Q system (Millipore, Bedford, MA).

Plant Material. C. argentea var. plumosa plants with violet inflorescences were obtained from Viveros la Generala (Murcia, Spain) and grown at the greenhouse facilities at the University of Murcia (Murcia, Southeastern Spain). Seeds were surface sterilized in commercial liquid detergent $1 \%$ for $15 \mathrm{~min}$, followed by $70 \%$ ethanol for $30 \mathrm{~s}$, and by $1.8 \%$ sodium hypoclorite solution containing $0.2 \%$ Tween-20 for $30 \mathrm{~min}$. Seeds were then washed three times with sterile water under aseptic conditions. Sterile seeds were transferred to sterilized tubes $(25 \times 150 \mathrm{~mm})$ containing $15 \mathrm{~mL}$ of semisolid Murashige and Skoog medium (MS). ${ }^{22}$ Seedlings were grown up to 2 $\mathrm{cm}$ (20 days), and then hypocotyls were removed as explants source. Hypocotyls were transferred to individual tubes $(n=6)$, with $10 \mathrm{~mL}$ of MS medium supplemented with different plant growth regulators (PGRs). Environmental conditions consisted of a photoperiod of $16 \mathrm{~h}$ under fluorescent light at an irradiance of $50 \mu \mathrm{mol} / \mathrm{m}^{2} / \mathrm{s}$ and temperatures of 23 (day) and $18{ }^{\circ} \mathrm{C}$ (night)

Callus Induction. The culture medium used was MS supplemented with $30 \mathrm{~g} / \mathrm{L}$ sucrose and $2 \mathrm{~g} / \mathrm{L}$ of the solidifying agent phytagel. To assess response to callus explant induction media were enriched with different concentrations and combinations of PGRs: 6- benzylaminopurine (BAP) (0.0, 4.44, 6.66, $8.88 \mu \mathrm{M})$ with 2,4dichlorophenoxyacetic acid (2,4-D) $(0.0,6.79,9.05 \mu \mathrm{M})$ (Table 1). All

Table 1. Effect of Plant Growth Regulators (PGRs) on Callus Induction from Hypocotyls Explants Obtained from C. argentea var. plumosa after 30 Days of Culture ${ }^{a}$

\begin{tabular}{ccc}
\multicolumn{2}{c}{ PGRs $(\mu \mathrm{M})$} & \\
\hline BAP & $2,4-\mathrm{D}$ & callus-forming explants $(\%)$ \\
0.00 & 0.00 & $0.00^{\mathrm{a}}$ \\
0.00 & 6.79 & $0.00^{\mathrm{a}}$ \\
0.00 & 9.05 & $0.00^{\mathrm{a}}$ \\
4.44 & 0.00 & $0.00^{\mathrm{a}}$ \\
4.44 & 6.79 & $0.00^{\mathrm{a}}$ \\
4.44 & 9.05 & $33.33^{\mathrm{a}, \mathrm{b}}$ \\
6.66 & 0.00 & $66.66^{\mathrm{b}}$ \\
6.66 & 6.79 & $100.00^{\mathrm{b}}$ \\
6.66 & 9.05 & $33.33^{\mathrm{a}, \mathrm{b}}$ \\
8.88 & 0.00 & $33.33^{\mathrm{a}, \mathrm{b}}$ \\
8.88 & 6.79 & $100.00^{\mathrm{b}}$ \\
8.88 & 9.05 & $100.00^{\mathrm{b}}$
\end{tabular}

${ }^{a}$ Each value was derived from three independent tubes containing three different explants. Those values sharing the same letter correspond to nonsignificant differences according to the Tukey test $(p<0.05)$.

culture media were adjusted to $\mathrm{pH} 5.8$ with $1 \mathrm{~N} \mathrm{NaOH}$ and $\mathrm{HCl}$ and sterilized by autoclaving at $121{ }^{\circ} \mathrm{C}$ for $18 \mathrm{~min}$. The cultures were incubated under a photoperiod of $16 \mathrm{~h}$ under fluorescent light at an irradiance of $50 \mu \mathrm{mol} / \mathrm{m}^{2} / \mathrm{s}$ and temperatures of 23 (day) and $18{ }^{\circ} \mathrm{C}$ (night). The response of the explants for callus formation at each induction treatment was expressed as the percentage of the number of forming callus hypocotyls explants on the total evaluated, which was recorded at day 30 of culture. Propagation of callus cell lines was done under the same conditions in a MS medium supplemented with 6.66 $\mu \mathrm{M}$ BAP and $6.79 \mu \mathrm{M} 2,4-\mathrm{D}$. It was selected for proliferation by subcultures on fresh medium with induction every 20 days for 9 subculture cycles. Subculturing and selection gave rise to two callus cell lines with different colors: yellow and red.

Establishment of Cell Suspension Culture and Growth Kinetics. C. argentea cell suspension culture was initiated from 3- 
week-old red friable callus by transferring $2.5 \mathrm{~g}$ to $100 \mathrm{~mL}$ Erlenmeyer flasks containing $30 \mathrm{~mL}$ of callus induction medium (without phytagel) supplemented with $10 \mathrm{mM}$ ascorbic acid in order to avoid dopamine oxidation and incubated under the same conditions on an orbital shaker at $110 \mathrm{rpm}$. After subculturing every 15 days during 3 months, the cells were sieved through $200 \mu$ m nylon cloth filters in order to obtain a homogeneous and fine cell suspension culture. Then, the culture was maintained during 6 months by subculturing every 15 days using a cell inoculum size of $10 \%(\mathrm{v} / \mathrm{v})$ in $500 \mathrm{~mL}$ Erlenmeyer flasks containing $100 \mathrm{~mL}$ of cultured medium. To determine the growth kinetics, $2.5 \mathrm{~g}$ of fresh cells harvested after 8 days was inoculated into $100 \mathrm{~mL}$ Erlenmeyer flasks containing $30 \mathrm{~mL}$ of liquid MS medium supplemented with $3 \%$ sucrose (w/v), $10 \mathrm{mM}$ ascorbic acid, BAP $6.66 \mu \mathrm{M}$, and 2,4-D $6.79 \mu \mathrm{M}$. Aliquots were removed every 3-10 days over a 30 day period from culture flasks and used to determine cell growth, cell morphology, cell viability, and dopamine and betalains content. All experiments were performed in triplicate $(n$ $=3$ ), and the results were expressed as mean values and standard deviations (SD).

Cell Viability. Cell viability was determined by the Evan's blue staining test. ${ }^{23}$ A $2 \mathrm{~mL}$ amount of samples from each flask was incubated into $0.25 \%$ Evan's blue stain for $5 \mathrm{~min}$, and then at least 700 cells were counted. This was repeated twice for each measurement $(n$ $=6$ ).

Preparation of Extracts. Callus samples and cell suspensions of 1, 8,15 , and 30 days of culture were homogenized manually in $10 \mathrm{mM}$ phosphate buffer $\mathrm{pH} 6.0$ containing $10 \mathrm{mM}$ ascorbic acid. The resulting homogenate and samples of the liquid medium of the suspension culture were centrifuged at $14000 \mathrm{~g}$ for $15 \mathrm{~min}$. The supernatant of each sample was used for analysis of betalains and dopamine $(n=3)$ by HPLC. The whole process was carried out at 4 ${ }^{\circ} \mathrm{C}$. The humidity percentage and dry weight of the cells was obtained with a Kern MLS electronic moisture analyzer (Balingen, Germany).

Standard Betalains. Betanin was obtained from roots of Beta vulgaris, dopaxanthin was extracted and purified from yellow flowers of L. productus, betanidin was obtained from violet flowers of the same plant, and amaranthin was extracted from Amaranthus spinosus. ${ }^{2,24}$ Other pigments were obtained by a combined procedure for the release of betalamic acid from purified betanin and condensation with the amine dopamine and the amino acids $(S)$-glutamine and $(S)$ tryptophan, following a previously described method. ${ }^{25}$ Betalamic acid was obtained through basic hydrolysis of betanin. ${ }^{26}$ All compounds were characterized spectrophotometrically, chromatographically, and by electrospray ionization mass spectrometry (ESI-MS).

Anionic Exchange Chromatography. Anionic exchange chromatography was performed in an Äkta purifier apparatus (Amersham Biosciences, Uppsala, Sweden) using a $25 \times 7 \mathrm{~mm}, 1 \mathrm{~mL}$ Q-Sepharose Fast Flow column (cross-linked agarose with quaternary ammonium as exchanger group, $90 \mu \mathrm{m}$ particle size). Solvents used were sodium phosphate $10 \mathrm{mM}, \mathrm{pH} 6.0$ (solvent A), and $10 \mathrm{mM}$ sodium phosphate, pH 6.0, with $2 \mathrm{M} \mathrm{NaCl}$ (solvent B). After sample injection, the elution process was as follows: $0 \% \mathrm{~B}$ from beginning to $3 \mathrm{~mL}$, and then a linear gradient was developed from $0 \%$ B to $35 \%$ B in $20 \mathrm{~mL}$. In all cases, the flow rate was $1 \mathrm{~mL} / \mathrm{min}, 1 \mathrm{~mL}$ fractions were collected, and injection volume was $1 \mathrm{~mL}$. Elutions were followed by UV-vis detection at 280, 480, and $536 \mathrm{~nm}$.

Solid-Phase Extraction. One milliliter C-18 cartridges (Waters, Milford, MA) were conditioned with $5 \mathrm{~mL}$ of ethanol followed by 10 $\mathrm{mL}$ of purified water. Aqueous solutions of extracted pigments and semisynthetic betalains were injected and bound to the minicolumn. Salts and buffers were washed off by rinsing the column with purified water. Betalains were eluted with ethanol, and the resulting fraction was evaporated to dryness under reduced pressure at room temperature. The residue was redissolved in water for further use or stored at $-80{ }^{\circ} \mathrm{C}$

HPLC-DAD Analysis. A Shimadzu LC-20AD apparatus (Kyoto, Japan) equipped with a SPD-M20A photodiode array detector (PDA) was used for analytical HPLC separations. Reversed phase chromatography was performed with a $250 \mathrm{~mm} \times 4.6 \mathrm{~mm}$ i.d., 5 $\mu \mathrm{m}$, Kromasil 100 C-18 column (Teknokroma, Barcelona, Spain) for identification of betalains. ${ }^{27}$ Solvent A was water with $0.05 \%$ trifluoroacetic acid (TFA), and solvent B was composed of acetonitrile with $0.05 \%$ TFA. A linear gradient was performed for $42 \mathrm{~min}$ from $0 \%$ $\mathrm{B}$ to $65 \% \mathrm{~B}$. The flow rate was $1 \mathrm{~mL} / \mathrm{min}$, operated at $30^{\circ} \mathrm{C}$. Elutions were followed at $\lambda=270$ (dopamine), 405 (betalamic acid), 480 (betaxanthins), and $536 \mathrm{~nm}$ (betacyanins). Injection volume was 40 $\mu \mathrm{L}$. Dopamine and betalains presented the same elution times as the corresponding standards in coelution experiments and superimposable spectra.

Elecrospray Ionization Mass Spectrometry. A VL 1100 apparatus with LC/MSD Trap (Agilent Technologies, Palo Alto, CA) was used for HPLC-ESI-MS analyses. Elution conditions were as described above using the same column $(250 \mathrm{~mm} \times 4.6 \mathrm{~mm}$ i.d., $5 \mu \mathrm{m}$, Kromasil $100 \mathrm{C}-18$ ) decreasing the flow rate to $0.8 \mathrm{~mL} / \mathrm{min}$. Vaporizer temperature was $350{ }^{\circ} \mathrm{C}$, and voltage was maintained at $3.5 \mathrm{kV}$. The sheath gas was nitrogen, operated at a pressure of 45 psi. Samples were ionized in positive mode. Ion monitoring mode was full scan in the range $m / z 50-1000$. The electron multiplier voltage for detection was $1350 \mathrm{~V}$.

UV-Vis Spectroscopy. A V-630 spectrometer (Jasco Corporation, Tokyo, Japan) attached to a Tectron thermostatic bath (JP Selecta, Barcelona, Spain) was used for UV-vis spectroscopy. For quantitation of betalains, pigment concentration was evaluated using molar extinction coefficients of $\varepsilon=46000$ (dopaxanthin), 27000 (betalamic acid), 44000 (tryptophan-betaxanthin), 46000 (dopaxanthin), 48000 (glutamine-betaxanthin and dopamine-betaxanthin), 65000 (betanin and amaranthin), and $54000 \mathrm{M}^{-1} \cdot \mathrm{cm}^{-1}$ (betanidin)..$^{28-30}$ All measurements were performed in water at $25{ }^{\circ} \mathrm{C}$.

Microscopy. Brightfield and fluorescence microscopy were performed in a Leica DMRB microscope (Leica Microsystems, Wetzlar, Germany) with incident light beam. In the case of fluorescence imaging, the filtercube I3 (Leica Microsystems) was used limiting excitation to the range $\lambda=450-490 \mathrm{~nm}$.

Statistical Analysis. Data analysis was carried out by using ANOVA variance parametric analysis and Tuckey range test $(P<0.05)$ using SPSS software, version 8.0 (SPSS, Chicago, IL). In each case, errors associated with the results provided were calculated on the basis of the residual standard deviation.

\section{RESULTS AND DISCUSSION}

Establishment of Callus Lines of C. argentea var. plumosa. All seeds from $C$. argentea var. plumosa were geminated on day 10 after sowing, with no sign of microbial contamination. Seedlings were maintained under aseptic conditions for 20 days and then used for callus induction experiments (Figure 2A). Hypocotyls were considered as primary explant sources due to the presence of meristem tissue and the reported endogenous levels of auxins and cytokines. ${ }^{31,32}$ Table 1 summarizes the results for callus induction as affected by the presence and concentration of different plant growth regulators. It can be seen that the sole presence of 2,4dichlorophenoxyacetic acid (2,4-D) was not enough to induce the formation of calli. Such inhibition of the cell growth could be due to the overexpression of genes ARR7 and ARR15 promoted by the auxin as previously reported. ${ }^{33}$ The presence of 6-benzylaminopurine (BAP) at a concentration $4.44 \mu \mathrm{M}$ also yielded negative results if no other regulator was present, in accordance to previous reports with Celosia cristata. ${ }^{34}$ Treatments with BAP at concentrations 6.66 and $8.88 \mu \mathrm{M}$ and the combination of $6.66 \mu \mathrm{M}$ BAP with 9.05 $\mu \mathrm{M}$ 2,4-D generated calli with pale brown color with yields of $33 \%$ or $66 \%$. Experiments with the highest concentrations of BAP and 2,4-D showed $100 \%$ induction capacity of white-green calli in 30-day cultures.

The medium suplemented with $6.66 \mu \mathrm{M}$ BAP and $6.79 \mu \mathrm{M}$ 2,4-D showed the highest cell growth, and the cell mass 


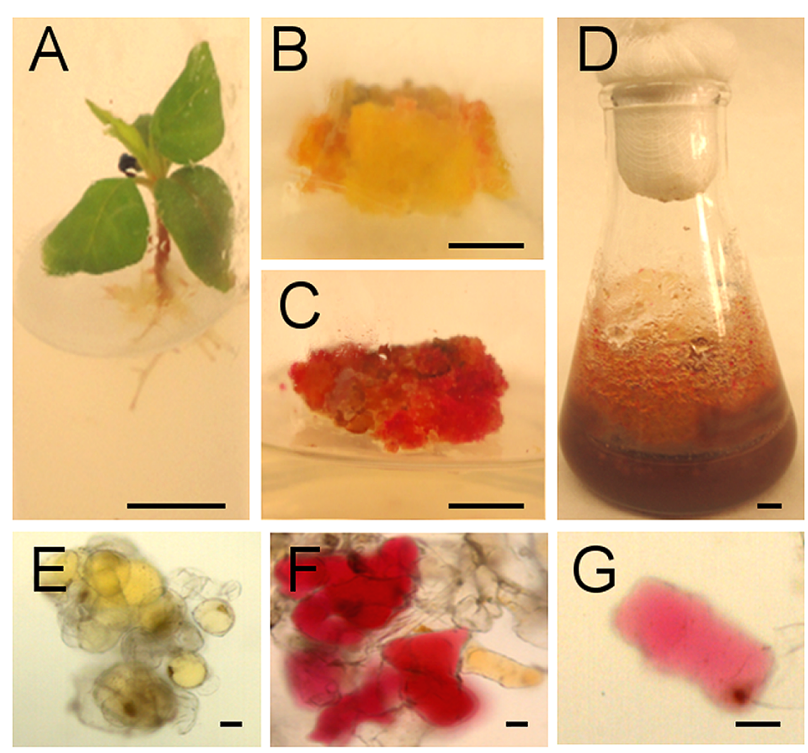

Figure 2. Establishment of in vitro cell lines derived from $C$. argentea var. plumosa. (A) Twenty days old seedling used as explants source. (B and C) Macroscopic images showing phenotypic characteristics for yellow and red callus lines, respectively. (D) Suspension culture 15 days after inoculation. (E, F, and G) Brightfield microscopic images of cells present in yellow callus, red callus, and suspension culture, respectively.

presented yellow and red color after 14 days of culture, spreading to the full explants at day 30 . The presence of yellow and red colors suggested the presence of betalains. These data are in relation to the observations on the halophytic plant Suaeda salsa, ${ }^{35}$ on C. cristata, $^{34,36}$ and on B. vulgaris cultures. ${ }^{37}$ Due to the presence of red and yellow hues and the culture characteristics, the medium supplemented with $6.66 \mu \mathrm{M}$ BAP and 6.79 $\mu \mathrm{M} 2,4-\mathrm{D}$ was considered for further experimentation. Callus propagation was performed in fresh medium every 20 days for 11 cycles (total cultivation time 7.5 months). As a result of this process two stable and differentially colored lines of $C$. argentea were established: yellow and red (Figure $2 \mathrm{~B}$ and 2C). Both cell lines obtained were observed under microscopy. The yellow line showed a round shape and yellow pigmentation compatible with the presence of betaxanthins (Figure 2E). The red cell line presented a morphology with round and elongated cells with a major presence of the former (Figure 2F). This phenomenon might be in relation with the cohesive properties of the cell wall reported to occur during plant cell division. ${ }^{38}$ Red pigmentation was observed within the line cells compatible with the presence of betacyanins.

Pigment Identification in Yellow and Red Cell Lines. The yellow and red $C$. argentea cell lines obtained were analyzed in terms of the presence of the bioactive pigments betalains. Samples from both lines were extracted and analyzed by HPLC with PDA and ESI-MS/MS detection (Table 2). The yellow line exhibited the major presence of the betaxanthins vulgaxanthin I (5), derived from L-glutamine $(1.78 \mathrm{mg} / \mathrm{g}$ dry weight) and miraxanthin $\mathrm{V}(2)$, derived from dopamine (1.64 $\mathrm{mg} / \mathrm{g}$ dry weight) (Table 2). Other betaxanthins detected were those derived from L-dihydroxyphenylalanine (L-DOPA), named dopaxanthin (1), and L-tryptophan (6). In addition to the yellow pigments, the betacyanins amaranthin (8) and betanin (7) and the dihydroxylated betanidin (3) and decarboxy-betanidin (4) were also identified.

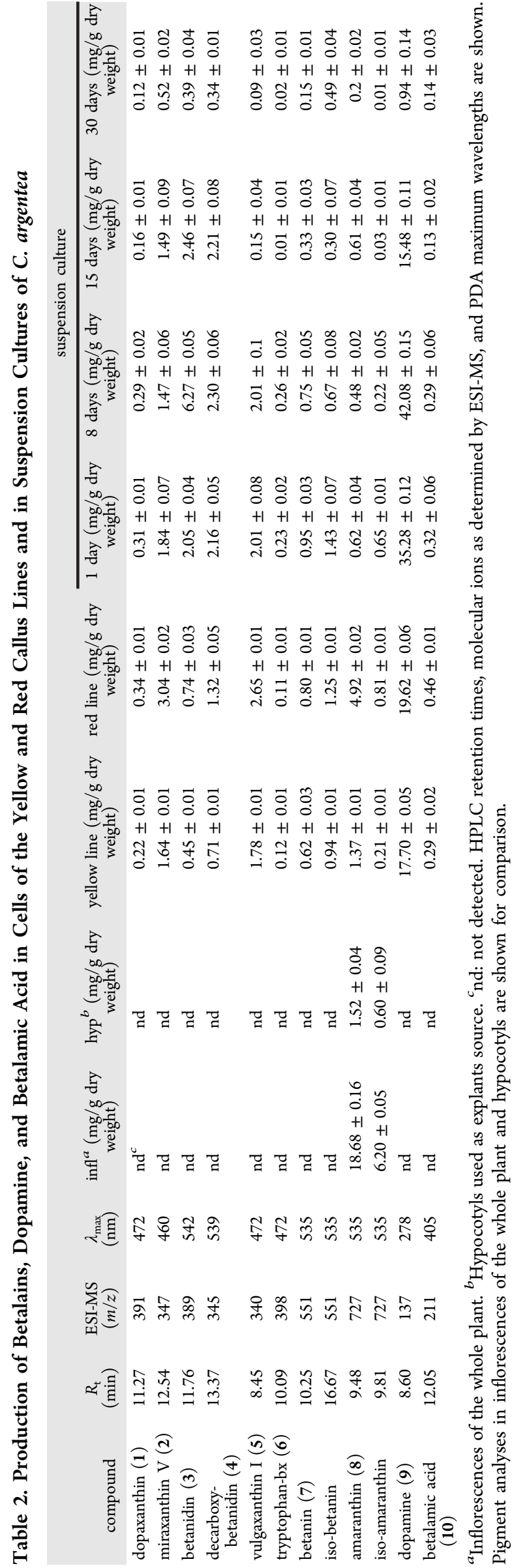


In the red line, coloration was also due to betalains and the content of betacyanins was higher. In this case the major pigment detected was the violet amaranthin (8) $(4.92 \mathrm{mg} / \mathrm{g}$ dry weight), accompanied by decarboxy-betanidin (4) $(1.32 \mathrm{mg} / \mathrm{g}$ dry weight), betanin (7) $(0.80 \mathrm{mg} / \mathrm{g}$ dry weight $)$, and betanidin (3) $(0.74 \mathrm{mg} / \mathrm{g}$ dry weight). Betaxanthins were also present (Table 2) with dopamine-derived betaxanthin (2) being the major yellow pigment $(3.04 \mathrm{mg} / \mathrm{g}$ dry weight). The joint presence of betacyanins (violet) and betaxanthins (yellow) yields the red color described for the cell mass. Inflorescences of the starting plant material and the hypocotyls used to establish the cell lines were violet. These two samples were also analyzed as a control, and only the presence of amaranthin (8) and its isomer iso-amaranthin were found (Table 2). The number of betalains present in the cell cultures indicates that the presence of $6.79 \mu \mathrm{M} \mathrm{2,4-D}$ and $6.66 \mu \mathrm{M}$ BAP promotes the biosynthesis of an increased number of betalains compared to the starting plant material. This could be due to the effect of 2,4-D and BAP in the concentrations mentioned on the expression of the key enzymes of the biosynthetic pathway of betalains: 4,5-DOPA-extradiol dioxygenase (DODA), tyrosinase, and cytochrome P450. In this sense, the levels of DODA mRNA and the accumulation of betalains have been previously correlated with the concentration of the growth regulators in in vitro cultures of S. salsa. ${ }^{35}$

The presence of betaxanthins in the cells of the yellow $C$. argentea line together with the described fluorescence of these pigments under physiological conditions ${ }^{39}$ makes the cells fluorescent in the visible range of the electromagnetic spectrum. Figure 3 shows the pictures derived from the betaxanthins

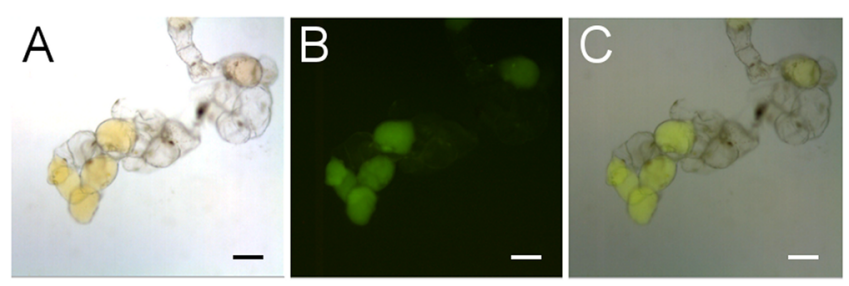

Figure 3. C. argentea microscopic images of cells present in the yellow line callus. (A) Brightfield technique. (B) Fluorescence. Only yellow portions of the brightfield image, containing betaxanthins, present light emission in the fluorescence image. (C) Combination of the previous two images.

autofluorescence obtained under a filter system able to irradiate the sample with blue light and to record the emitted light in the green range of the visible spectrum. As can be seen, only the yellow portions of the brightfield image, containing the yellow pigments, present light emission in the fluorescence image. Fluorescence of betaxanthins has previously been used to visualize petal cells ${ }^{39}$ and to detect the presence of Plasmodium falciparum (malaria) in erythrocytes. ${ }^{40}$ However, this is the first time that betalains fluorescence was demonstrated to be of utility in the visualization of plant single cells grown in vitro.

All pigments were identified by comparison with real standards in terms of HPLC retention times, PDA spectra, and electrospray ionization mass spectrometry (ESI-MS) analyses. The mass values determined for the parent ions of all compounds were as expected for the corresponding protonated molecular ions $[\mathrm{M}+\mathrm{H}]^{+}$of the betalains, thus confirming the proposed structures (Table 2). For pigments containing a quaternary ammonium substructure, the mass obtained corresponds to the charged form, as drawn in Figure 1. In all cases a daughter ion corresponding to $m / z[\mathrm{M}+\mathrm{H}]^{+}-$ 44 was detected, accounting for loss of a carboxylic group. For betanin (7) $\left(R_{\mathrm{t}} 10.25 \mathrm{~min}\right)$, the main daughter ion was $\mathrm{m} / z$ 389 , corresponding to the mass determined for betanidin (3), obtained through cleavage of the glucose unit at the level of the $O$-glucosidic bond $\left(m / z[\mathrm{M}+\mathrm{H}]^{+}-162\right)$. Amaranthin $(8)\left(R_{\mathrm{t}}\right.$ $9.48 \mathrm{~min}$ ) yielded a molecular ion of $\mathrm{m} / \mathrm{z} 727$ that was fragmented into $m / z 551$, corresponding to loss of a glucuronic acid moiety $m / z[\mathrm{M}+\mathrm{H}]^{+}-176$ (betanin), and into $m / z 389$, corresponding to an additional loss of glucose $m / z[\mathrm{M}+\mathrm{H}]^{+}-$ 176-162 (betanidin). Betanidin (3) itself was also present in the extracts derived from both cell lines $\left(R_{\mathrm{t}} 11.76 \mathrm{~min}\right)$. Thus, all the intermediates of the biochemical route of carboxylated betacyanins from betanidin to amaranthin were present. This suggests the transformation of betanidin (3) into betanin (7) by glucosylation ${ }^{16}$ and betanin into amaranthin ( 8 ) by addition of a glucuronic acid residue. The presence of the intermediates points to the biosynthesis of amaranthin in the callus through this route instead of via cyclo-DOPA glucosylation and glucuronylation and further condensation with betanidin. ${ }^{41}$ These intermediates were not present in the starting plant material inflorescences or hypocotyls, where only the final product of the route amaranthin was detected.

The possible presence in the cell cultures of the structural unit of all betalains, betalamic acid (10), and the precursor molecule for miraxanthin $\mathrm{V}$, dopamine (9), was also investigated. Betalamic acid could be detected in the yellow C. argentea cell line at $0.29 \mathrm{mg} / \mathrm{g}$ dry weight (Table 2), while in the red line a higher content was detected with $0.46 \mathrm{mg} / \mathrm{g}$ dry weight. The presence of betalamic acid (10) complements the presence of intermediates of the biosynthetic pathway of betalains. It is an elusive molecule derived from cyclization of the 4,5-seco-DOPA molecule obtained by intramolecular cleavage of the amino acid L-DOPA by the enzyme 4,5DOPA-extradiol-dioxygenase. ${ }^{2}$ Free betalamic acid has previously been found as a natural constituent in fruits of Opuntia ficus-indica. ${ }^{42}$ Dopamine (9) was also detected in the cell lines at significant quantities. Identification was corroborated by comparison with commercial standard $\left(R_{\mathrm{t}} 8.60 \mathrm{~min}\right)$ and ESIMS. A predominant daughter ion of $\mathrm{m} / z 137$ resulting from loss of the amine group was found in the standard and culturederived compound. This metabolite was not detected in the plant inflorescences or hypocotyls, but its presence accounts for $17.70 \mathrm{mg} / \mathrm{g}$ dry weight in the yellow cell line and $19.63 \mathrm{mg} / \mathrm{g}$ dry weight in the red line. In addition to its role as the building block of betalains, betalamic acid itself is a natural pigment with strong antioxidant activity. ${ }^{26}$ Dopamine acts as a neurotransmitter, and its deficit has been reported in mental illness such as depression. 5

The presence of the dihydroxylated betacyanins betanidin (3) and decarboxy-betanidin (4) and the DOPA and dopamine-derived betaxanthins $(\mathbf{1}, 2)$ in the obtained cell cultures is of particular relevance due to their strong antioxidant and free radical scavenging activities. ${ }^{3,4,43}$ Furthermore, the tryptophan-derived betaxanthin (6) present in both cell lines has recently been identified among all traditional Chinese medicine phytochemicals in a massive in silico screening as a bioactive compound interacting with the age-related enzymes sirtuins. ${ }^{44}$ Tryptophan-derived betaxanthin is a lead compound with possible application in drug development for diseases associated with aging. 

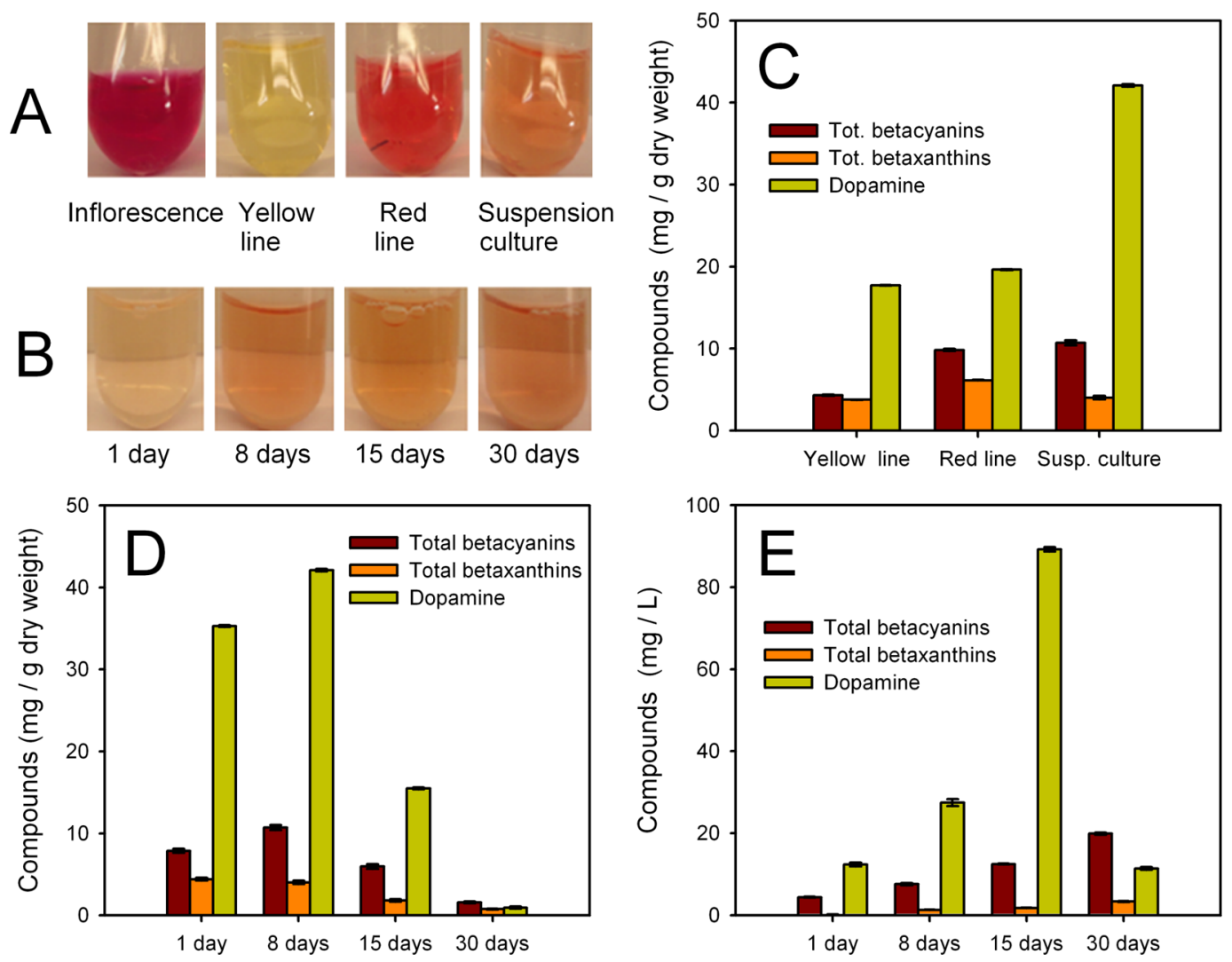

Figure 4. Production of betalains and dopamine by cell lines derived from C. argentea var. plumosa. (A) Picture showing the pigmentation of cell extracts obtained from plant inflorescences, yellow callus line, red callus line, and suspension culture 8 days after inoculation. (B) Color evolution of the liquid culture medium photographed $1,8,15$, and 30 days after inoculation. (C) Total pigment content and dopamine presence in extracts obtained from solid and suspension cultures. (D) Time evolution for the production of betalains and dopamine in the cells of the suspension culture at the indicated times after inoculation. (E) Time evolution for the presence of betalains and dopamine in the liquid medium at the indicated times after inoculation.

Suspension Cultures of C. argentea. The analyses performed in the cell lines derived from C. argentea show that the red line produces higher levels of dopamine, betacyanins, and betaxanthins than the yellow homologue (Figure 4C). Thus, the red cell line was chosen to attempt a suspension culture of $C$. argentea that could be used to produce the identified phytochemicals. The liquid culture was successfully established in MS liquid medium supplemented with $30 \mathrm{~g} / \mathrm{L}$ sucrose, $6.66 \mu \mathrm{M}$ BAP, $6.79 \mu \mathrm{M}$ 2,4-D, and $10 \mathrm{mM}$ ascorbic acid. Figure 2D shows the established culture. The cell growth curve (Figure 5) indicates that a lag phase was present for 4 days, in which biomass reached $3.18 \mathrm{~g}$ dry weight/L. After this time, cells entered exponential growth phase. Growth was prolonged up to day 15 , and in that time the accumulated biomass was $10.96 \mathrm{~g}$ dry weight/L. During this phase, the doubling time of the culture was 6.1 days with a calculated growth rate $(\mu)$ of $0.113 /$ day.

During the whole culture time the $\mathrm{pH}$ of the suspension was monitored (results not shown) with no significant variation being recorded and a mean $\mathrm{pH}$ value of 4.9. This is a convenient $\mathrm{pH}$ value to promote the stability of the pigments betalains with special emphasis of those containing the dihydroxylated moiety. ${ }^{21}$ The cell shape found in suspension was elongated, showing predominantly red coloration $(96 \%)$ (Figure $2 \mathrm{G}$ ). In addition to the red-colored cells, yellow cells were detected in a much lesser extent (4\%). This points to the joint presence of betaxanthins and betacyanins in the majority of cells, as detected in the red callus used to start the liquid

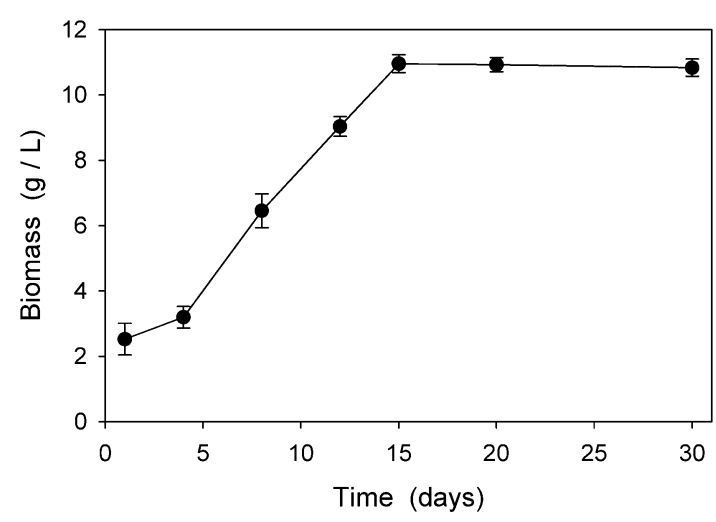

Figure 5. Growth curve for the suspension culture of $C$. argentea obtained in MS liquid medium supplemented with $30 \mathrm{~g} / \mathrm{L}$ sucrose, $6.66 \mu \mathrm{M}$ BAP, $6.79 \mu \mathrm{M} 2,4-\mathrm{D}$, and $10 \mathrm{mM}$ ascorbic acid.

culture. Cells tended to form aggregates, probably in relation to the cohesive properties of the cell wall and the hydrodynamic stress experienced in suspension culture. ${ }^{38}$ Cell viability was also monitored during the process and maintained at $74 \%$ during the 30 days of culture period. Viability is well above the limit of $50 \%$ considered as positive in plant cell culture, ${ }^{45}$ thus confirming the success of the $C$. argentea suspension culture.

Production of Betalains and Dopamine in Liquid Culture. The presence of betalains and dopamine in $C$. argentea liquid culture was analyzed by HPLC-PDA and ESI- 
Table 3. Production of Betalains, Dopamine, and Betalamic Acid in the Liquid Medium of Suspension Cultures of C. argentea

\begin{tabular}{|c|c|c|c|c|}
\hline compound & 1 day $(\mathrm{mg} / \mathrm{L})$ & 8 days $(\mathrm{mg} / \mathrm{L})$ & 15 days $(\mathrm{mg} / \mathrm{L})$ & 30 days $(\mathrm{mg} / \mathrm{L})$ \\
\hline dopaxanthin (1) & $\mathrm{nd}^{a}$ & nd & nd & nd \\
\hline miraxanthin $\mathrm{V}(2)$ & $0.03 \pm 0.01$ & $0.40 \pm 0.05$ & $0.50 \pm 0.02$ & $1.17 \pm 0.04$ \\
\hline betanidin ( 3 ) & $0.50 \pm 0.04$ & $2.85 \pm 0.11$ & $6.75 \pm 0.02$ & $13.40 \pm 0.04$ \\
\hline decarboxy-betanidin (4) & $1.14 \pm 0.05$ & $1.51 \pm 0.20$ & $2.47 \pm 0.03$ & $4.17 \pm 0.09$ \\
\hline vulgaxanthin I (5) & $0.08 \pm 0.03$ & $0.88 \pm 0.02$ & $1.24 \pm 0.03$ & $2.16 \pm 0.06$ \\
\hline tryptophan-bx (6) & nd & nd & nd & nd \\
\hline betanin (7) & nd & nd & nd & nd \\
\hline iso-betanin & nd & nd & nd & nd \\
\hline amaranthin (8) & $2.70 \pm 0.07$ & $3.04 \pm 0.11$ & $2.99 \pm 0.02$ & $2.33 \pm 0.08$ \\
\hline iso-amaranthin & $0.04 \pm 0.01$ & $0.12 \pm 0.04$ & $0.24 \pm 0.03$ & $0.04 \pm 0.03$ \\
\hline dopamine (9) & $12.34 \pm 0.48$ & $27.42 \pm 0.85$ & $89.20 \pm 0.51$ & $11.35 \pm 0.35$ \\
\hline betalamic acid (10) & $0.88 \pm 0.02$ & $0.84 \pm 0.01$ & $1.23 \pm 0.03$ & $3.63 \pm 0.06$ \\
\hline
\end{tabular}

MS. Pigments were identified and quantitated both in cells and in liquid medium at different culture times. Cell extracts and media analyses were performed at days $1,8,15$, and 30 as shown in Tables 2 and 3 . Cells exhibited maximum accumulation of total betalains at day 8 , corresponding to the exponential growth phase (Figure 4D). Up to 10 pigments were identified corresponding to those present in the calli with a higher content of miraxanthin V (2) $(1.84 \mathrm{mg} / \mathrm{g}$ dry weight), vulgaxanthin $\mathrm{I}(5)(2.01 \mathrm{mg} / \mathrm{g}$ dry weight), and betanidin (3) (6.27 mg/g dry weight).

This pigment content explains the cell suspension coloration and suggests the possible secretion of pigments into the culture medium. Table 3 shows the results for the analyses of the medium at different culture times. The presence of betalains was detected during all of the process, increasing with incubation time (Figure 4B and 4E). Pigments identified in the culture medium were betalamic acid (10), vulgaxanthin I (5), miraxanthin V (2), amaranthin (8), and betanidin (3). The total quantity of betalains detected at the end of culture (day 30) was $23.27 \mathrm{mg} / \mathrm{L}$, mainly accounting for the presence of the dihydroxylated betacyanin betanidin (3) (13.40 mg/L). Betanidin, which is the betalain with the strongest antioxidant and free radical scavenging activities and also involved in the anti-inflammatory potential of betalain-containing extracts, ${ }^{46,47}$ is here the betalain produced in a higher extent.

Cells grown in liquid culture presented a significant increase in the content of dopamine (9) in comparison to the levels detected in the cells grown in solid media. After 8 days in liquid culture the levels of dopamine in the cells were $42.08 \mathrm{mg} / \mathrm{g}$ dry weight, which is more than double the levels found in the cells grown in solid media ( $19.62 \mathrm{mg} / \mathrm{g}$ dry weight for the red line) (Figure 4C). Plant cells in suspension suffer hydrodynamic forces due to continuous shaking which generates a stress probably involved in the increase of the secondary metabolism. ${ }^{48,49}$ Dopamine was also detected to a lesser extent in the culture medium. Figure 4E shows the time evolution of dopamine content. In this case the maximum concentration was achieved after 15 days of culture with a content of $89 \mathrm{mg} / \mathrm{L}$. Although the presence of dopamine in C. argentea was known for intact plants, ${ }^{12}$ this is the first report on the production of the metabolite in cell culture. In vitro production of dopamine through a plant cell culture was previously only attempted for another plant belonging to the Caryophyllales, Portulaca oleracea but using Agrobacterium rhizogenes transformation. This achieved a maximum production of dopamine of $0.90 \mathrm{mg} /$ $\mathrm{g}$ dry weight after 28 days of culture and chemical elicitation. ${ }^{50}$
This value is far from the $42.08 \mathrm{mg} / \mathrm{g}$ dry weight obtained here in only 8 days with untransformed cells of $C$. argentea, thus significantly increasing the yield and reducing the culture time.

Cell cultures of $C$. argentea produce four dihydroxylated betalains with the highest antioxidant and free radical scavenging activities, the carboxylated dopaxanthin (1) and betanidin (3) and the decarboxylated homologues miraxanthin $\mathrm{V}$ (2) and decarboxy-betanidin (4). In addition, they produce tryptophan-betaxanthin (6), which has been identified among the bioactive compounds of the traditional Chinese medicine database for their interaction with the age-related enzymes sirtuins. The joint presence of these bioactive betalains together with the production of dopamine (9) shows the ability of cell cultures of $C$. argentea to become stable sources of valuable phytochemicals of potential application in the food, pharmaceutical, and cosmetic fields.

\section{AUTHOR INFORMATION}

\section{Corresponding Author}

*Tel.: +34 868 884786. Fax: +34 868 884147. E-mail: fgandia@ um.es.

\section{Funding}

This work was supported by "Ministerio de Ciencia e Innovación” (MCINN, FEDER, Spain) (Projects AGL201125023 and AGL2014-57431). B.G.-F. holds a fellowship from "Consejo Nacional de Ciencia y Tecnología" and the "Asociación Universitaria Iberoamericana de Postgrado" (CONACYT, Mexico and AUIP, Spain). F G.-H. has a contract with the "Programa Ramón y Cajal" (MCINN, FEDER, Spain).

\section{Notes}

The authors declare no competing financial interest.

\section{ACKNOWLEDGMENTS}

The authors are grateful to Dr. María Inmaculada García, Dr. María Teresa Castells, and Dr. José Rodríguez (SAI, University of Murcia) for skillful technical assistance in Image Analysis and ESI-MS experiments.

\section{REFERENCES}

(1) Gandía-Herrero, F.; Escribano, J.; García-Carmona, F. Biological activities of plant pigments betalains. Crit. Rev. Food Sci. Nutr. 2015, DOI: $10.1080 / 10408398.2012 .740103$.

(2) Gandía-Herrero, F.; García-Carmona, F. Biosynthesis of betalains: yellow and violet plant pigments. Trends Plant Sci. 2013, $18,334-343$. 
(3) Gandía-Herrero, F.; Escribano, J.; García-Carmona, F. The role of phenolic hydroxy groups in the free radical scavenging activity of betalains. J. Nat. Prod. 2009, 72, 1142-1146.

(4) Gliszczyńska-Świgło, A.; Szymusiak, H.; Malinowska, P. Betanin, the main pigment of red beet: Molecular origin of its exceptionally high free radical-scavenging activity. Food Addit. Contam. 2006, 23, 1079-1087.

(5) Dunlop, B. W.; Nemeroff, C. B. The role of dopamine in the pathophysiology of depression. Arch. Gen. Psychiatry 2007, 64, 327337.

(6) Fifel, K.; Cooper, H. M. Loss of dopamine disrupts circadian rhythms in a mouse model of Parkinson's disease. Neurobiol. Dis. 2014, 71, 359-369.

(7) del Campo, N.; Chamberlain, S. R.; Sahakian, B. J.; Robbins, T. $\mathrm{W}$. The roles of dopamine and noradrenaline in the pathophysiology and treatment of attention-deficit/hyperactivity disorder. Biol. Psychiatry 2011, 69, E145-E157.

(8) Vasu, T. S.; Cavallazzi, R.; Hirani, A.; Kaplan, G.; Leiby, B.; Marik, P. E. Norepinephrine or dopamine for septic shock: systematic review of randomized clinical trials. J. Intensive Care Med. 2012, 27, 172-178.

(9) Piattelli, M.; Minale, L.; Nicolaus, R. A. Betaxanthins from Mirabilis jalapa L. Phytochemistry 1965, 4, 817-823.

(10) Kugler, F.; Stintzing, F. C.; Carle, R. Identification of betalains from petioles of differently colored Swiss chard (Beta vulgaris L. ssp. cicla [L.] alef. cv. bright lights) by high-performance liquid chromatography-electrospray ionization mass spectrometry. J. Agric. Food Chem. 2004, 52, 2975-2981.

(11) Trezzini, G. F.; Zrÿd, J.-P. Two betalains from Portulaca grandiflora. Phytochemistry 1991, 30, 1897-1899.

(12) Schliemann, W.; Cai, Y.; Degenkolb, T.; Schmidt, J.; Corke, H. Betalains of Celosia argentea. Phytochemistry 2001, 58, 159-165.

(13) Piattelli, M.; Impellizzeri, G. 2-Descarboxybetanidin, a minor betacyanin from Carpobrothus acinaciformis. Phytochemistry 1970, 9, $2553-2556$.

(14) Kobayashi, N.; Schmidt, J.; Wray, V.; Schliemann, W. Formation and occurrence of dopamine-derived betacyanins. Phytochemistry 2001, $56,429-436$.

(15) Impellizzeri, G.; Piattelli, M.; Sciuto, S. A new betaxanthin from Glottiphyllum longum. Phytochemistry 1973, 12, 2293-2294.

(16) Hans, J.; Brandt, W.; Vogt, T. Site-directed mutagenesis and protein 3D-homology modeling suggest a catalytic mechanism for UDP-glucose-dependent betanidin 5-O-glucosyltransferase from Dorotheanthus bellidiformis. Plant J. 2004, 39, 319-333.

(17) Amin, I.; Norazaidah, Y.; Hainida, K. I. E. Antioxidant activity and phenolic content of raw and blanched Amaranthus species. Food Chem. 2006, 94, 47-52.

(18) Sang-Uk, C.; Buk-Gu, H.; Yong-Seo, P.; Dong-Kwan, K.; Shela, G. Total phenolics level, antioxidant activities and cytotoxicity of young sprouts of some traditional Korean salad plants. Plant Foods Hum. Nutr. 2009, 64, 25-31.

(19) Ibrahim, B.; Sowemimo, A.; van Rooyen, A.; Van de Venter, M. Antiinflammatory, analgesic and antioxidant activities of Cyathula prostrate (Linn.) Blume (Amaranthaceae). J. Ethnopharmacol. 2012, $141,282-289$.

(20) Silva, L. R.; Valentão, P.; Faria, J.; Ferreres, F.; Sousa, C.; GilIzquierdo, A.; Pinho, B. R.; Andrade, P. B. Phytochemical investigations and biological potential screening with cellular and non-cellular models of globe amaranth (Gomphrena globosa L.) inflorescences. Food Chem. 2012, 135, 756-763.

(21) Gandía-Herrero, F.; Cabanes, J.; Escribano, J.; García-Carmona, F.; Jiménez-Atiénzar, M. Encapsulation of the most potent antioxidant betalains in edible matrixes as powders of different colors. J. Agric. Food Chem. 2013, 61, 4294-4302.

(22) Murashige, T.; Skoog, F. A revised medium for rapid growth and bioassays with tobacco tissue cultures. Physiol. Plant. 1962, 15, 473-97.

(23) Rodríguez-Monroy, M.; Galindo, E. Broth rheology, growth and metabolite production of Beta vulgaris suspension culture: a comparative study between cultures grown in shake flasks and in stirred tank. Enzyme Microb. Technol. 1999, 24, 687-693.

(24) Cai, Y.-Z.; Sun, M.; Corke, H. Characterization and application of betalain pigments from plants of the Amaranthaceae. Trends Food Sci. Technol. 2005, 16, 370-376.

(25) Gandía-Herrero, F.; García-Carmona, F.; Escribano, J. Development of a protocol for the semi-synthesis and purification of betaxanthins. Phytochem. Anal. 2006, 17, 262-269.

(26) Gandía-Herrero, F.; Escribano, J.; García-Carmona, F. Purification and antiradical properties of the structural unit of betalains. J. Nat. Prod. 2012, 75, 1030-1036.

(27) Gandía-Herrero, F.; García-Carmona, F.; Escribano, J. A novel method using high-performance liquid chromatography with fluorescence detection for the determination of betaxanthins. J. Chromatogr. A 2005, 1078, 83-89.

(28) Schwartz, S. J.; von Elbe, J. H. Quantitative determination of individual betacyanin pigments by high-performance liquid chromatography. J. Agric. Food Chem. 1980, 28, 540-543.

(29) Trezzini, G. F.; Zrÿd, J.-P. Characterization of some natural and semisynthetic betaxanthins. Phytochemistry 1991, 30, 1901-1904.

(30) Gandía-Herrero, F.; Escribano, J.; García-Carmona, F. Structural implications on color, fluorescence, and antiradical activity in betalains. Planta 2010, 232, 449-460.

(31) Chapman, E. J.; Greenham K.; Castillejo, C.; Sartor, R.; Bialy, A. Hypocotyl transcriptome reveals auxin regulation of growth-promoting genes through ga-dependent and independent pathways. PLoS One 2012, 7, 10.1371/journal.pone.0036210.

(32) Abu-Romman, S. The influence of plant growth regulators on callus induction from hypocotyls of cucumber (Cucumis sativus L.). Adv. Environ. Biol. 2013, 7, 339-343.

(33) Ying-Hua, S.; Yu-Bo, L.; Xian-Sheng, Z. Auxin-cytokinin interaction regulates meristem development. Mol. Plant 2011, 4, 616-625.

(34) Taha, R. M.; Wafa, S. N. Plant regeneration and cellular behaviour studies in Celosia cristata grown in vivo and in vitro. Sci. World J. 2012, DOI: 10.1100/2012/359413.

(35) Zhao, S. Z.; Sun, H. Z.; Gao, Y.; Sui, N.; Wang, B. S. Growth regulator-induced betacyanin accumulation and dopa-4,5-dioxygenase (DODA) gene expression in euhalophyte Suaeda salsa calli. In Vitro Cell. Dev. Biol.: Plant 2011, 47, 391-398.

(36) Jamilah, S. Y.; Azani, S.; Hashimah, E.; Sakinah, A.; Noraini, M.; Normadiha, M. In vitro regeneration and acclimatization protocols of selected ornamental plants (Agapanthus praecox, Justicia betonica and Celosia cristata). Sains Malays. 2014, 43, 715-722.

(37) Akita, T.; Hina, Y.; Nishi, T. Production of betacyanins by a cell suspension culture of table beet (Beta vulgaris L.). Biosci., Biotechnol., Biochem. 2000, 64, 1807-1812.

(38) Trejo-Tapia, G.; Rodríguez-Monroy, M. Cellular aggregation in secondary metabolite production in in vitro plant cell cultures. Interciencia 2007, 32, 669-674.

(39) Gandía-Herrero, F.; García-Carmona, F.; Escribano, J. Floral fluorescence effect. Nature 2005, 437, 334-334.

(40) Gonçalves, L. C. P.; Tonelli, R. R.; Bagnaresi, P.; Mortara, R. A.; Ferreira, A. G.; Bastos, E. L. A nature-inspired betalainic probe for livecell imaging of Plasmodium-infected erythrocytes. PLoS One 2013, 8, e53874.

(41) Sasaki, N.; Abe, Y.; Wada, K.; Koda, T.; Goda, Y.; Adachi, T.; Ozeki, Y. Amaranthin in feather cockscombs is synthesized via glucuronylation at the cyclo-DOPA glucoside step in the betacyanin biosynthetic pathway. J. Plant Res. 2005, 118, 439-442.

(42) Stintzing, F. C.; Schieber, A.; Carle, R. Amino acid composition and betaxanthin formation in fruits from Opuntia ficus-indica. Planta Med. 1999, 65, 632-635.

(43) Cai, Y.; Sun, M.; Corke, H. Antioxidant activity of betalains from plants of the Amaranthaceae. J. Agric. Food Chem. 2003, 51, 22882294.

(44) Chen, K.-C.; Jian, Y.-R.; Sun, M.-F.; Chang, T.-T.; Lee, C.-C.; Chen, C. Y.-C. Investigation of silent information regulator 1 (Sirt1) 
agonists from traditional Chinese medicine. J. Biomol. Struct. Dyn. 2013, 31, 1207-1218.

(45) Qui, J. A.; Castro-Concha, L. A.; García-Sosa, K.; PeñaRodríguez, L. M.; Miranda-Ham, M. L. Differential effects of phytotoxic metabolites from Alternaria tagetica on Tagetes erecta cell cultures. J. Gen. Plant Pathol. 2009, 75, 331-339.

(46) Vidal, P. J.; López-Nicolás, J. M.; Gandía-Herrero, F.; GarcíaCarmona, F. Inactivation of lipoxygenase and cyclooxygenase by natural betalains and semi-synthetic analogues. Food Chem. 2014, 154, 246-254.

(47) Martinez, R. M.; Longhi-Balbinot, D. T.; Zarpelon, A. C.; Staurengo-Ferrari, L.; Baracat, M. M.; Georgetti, S. R.; Sassonia, R. C.; Verri, W. A., Jr.; Casagrande, R. Anti-inflammatory activity of betalainrich dye of Beta vulgaris: effect on edema, leukocyte recruitment, superoxide anion and cytokine production. Arch. Pharmacal Res. 2014, DOI: $10.1007 / \mathrm{s} 12272-014-0473-7$.

(48) Hua, J.; Erickson, E.; Yiin, T. Y.; Glasgow, L. A review of the effects of shear and interfacial phenomena on cell viability. Crit. Rev. Biotechnol. 1993, 13, 305-328.

(49) Joshi, J. B.; Elias, C. B.; Patole, M. S. Role of hydrodynamic shear in cultivation of animal, plant and microbial cells. Chem. Eng. J. 1996, 62, 121-141.

(50) Ahmadi-Moghadam, Y.; Piri, Kh.; Bahramnejad, B.; Ghiasvand, T. Dopamine production in hairy root cultures of Portulaca oleracea (purslane) using Agrobacterium rhizogenes. J. Agric. Sci. Technol. 2014, 16, 409-420. 
PRODUCCION DE BETALAINAS EN CULTIVOS in vitro DE AMARANTHACEAS
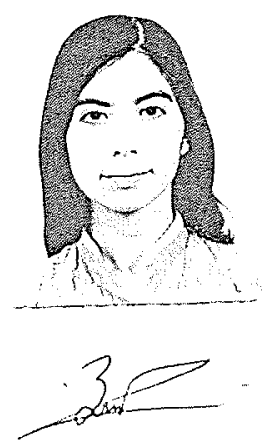

BERENICE GUADARRAMA FLORES ALUMNA

REVISO

LIC. JULIO CESAR DE LARA ISASSI DIRECTOR DE SISTEMAS ESCOLARES
En México, D.F., se presentaron a las 12:00 horas del día 17 del mes de julio del año 2015 en la unidad Iztapalapa de la Universidad Autónoma Metropolitana, los suscritos miembros del jurado:

DR. JOSE RAMON VERDE CALVO

DRA. MARIA ELENA ESTRADA ZUÑIGA

DRA. MARIA DEL PILAR NICASIO TORRES

DRA. ANGELICA ROMAN GUERRERO
Bajola Presidencia del primero y con caracter de Secretaria la última, se reunieron a la presentación de la Disertación Pública cuya denominación aparece al margen, para la obtención del grado de:

DOCTORA EN BIOTECNOLOGIA

DE: BERENICE GUADARRAMA FLORES

y de acuerdo con el artículo 78 fracción IV del Reglamento de Estudios Superiores de la universidad Rutónoma Metropolitana, los miembros del jurado resolvieron:

\section{Aprobar}

Acto continuo, el presidente del jurado comunicó a la interesada el resultado de la evaluación $y$, en caso aprobatorio, le fue tomada la protesta.
DIRECTORA DE LA DIVISIÓN DE CBS

DRA. EDITH PONCE ALQUICIRA

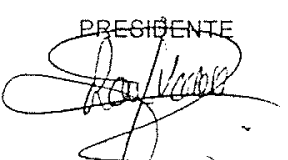

DR. JOSE RAMON VERDE CALVO

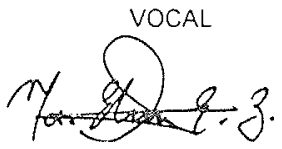

DRA. MARIA ELENA ESTRADA ZUÑIGA

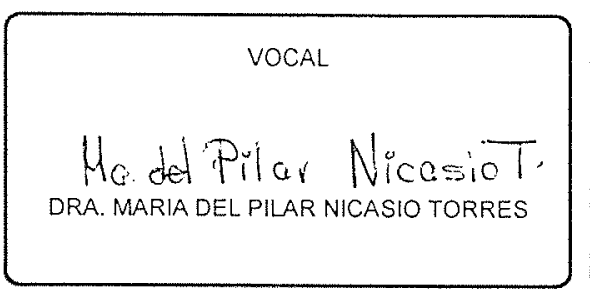

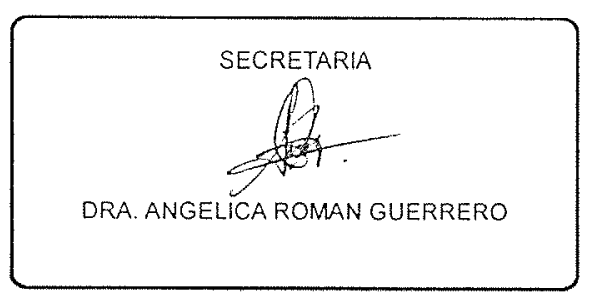


CONSTANCIA DE PRESENTACION DE EXAMEN DE GRADO

La Universidad Autónoma Metropolitana extiende la presente CONSTANCIA DE PRESENTACION DE DISERTACIÓN PÚBLICA de DOCTORA EN BIOTECNOLOGIA de la alumna BERENICE GUADARRAMA FLORES, matrícula 2113803171, quien cumplió con 10 s 256 créditos correspondientes a las unidades de enseñanza aprendizaje del plan de estudio, 45 créditos de PUBLICACION y 45 créditos de EXAMEN PREDOCTORAL. Con fecha diecisiete de julio del 2015 presentó la DEFENSA de su DISERTACIÓN PÚBLICA cuya denominación es:

PRODUCCION DE BETALAINAS EN CULTIVOS in vitro DE AMARANTHACEAS

Cabe mencionar que la aprobación tiene un valor de 45 créditos y el programa consta de 391 créditos.

El jurado del examen ha tenido a bien otorgarle la calificación de:

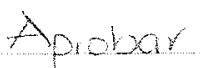

JURADO

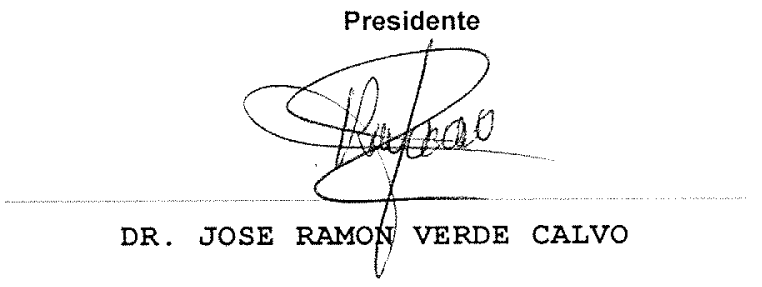

Vocal

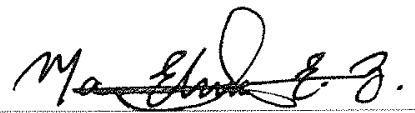

DRA. MARIA ELENA ESTRADA ZUÑ̃IGA

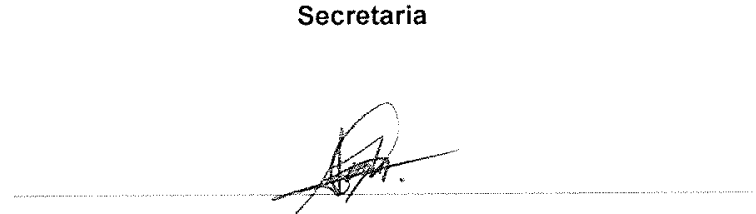

DRA. ANGEIICA ROMAN GUERRERO

Vocal

Ma. del Pilar Nicasiot.

DRA. MARIA DEL PILAR NICASIO TORRES 


\title{
$\Delta 4$ \\ Antartin \\ UNIVERSIDAD AUTONOMA METROPOLITANA IZTAPALAPA
}

\author{
Otorga el presente reconocimiento a
}

\section{BERENICE GUADARRAMA FLORES}

En virtud de haber aprobado el examen de grado de

\section{DOCTORADO EN BIOTECNOLOGÍA}

De la División de Ciencias Biológicas y de la Salud

México, D.F., a 17 de julio de 2015.

Dr. Francisco Cruz Sosa Dr. Mario Rodriguez Monroy

Co-Directores de Tesis

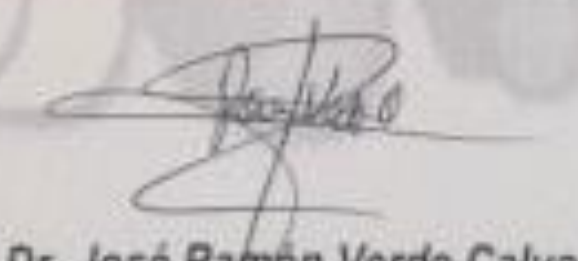

Dr. José Ramón Verde Calvo Presidente del Jurado

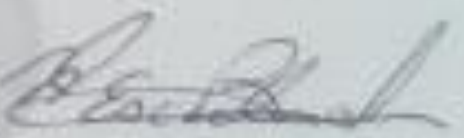

Dr. Héctor B. Escalona Buendia Coordinador del Posgrado 